



Lut Dumy/861<smiles>CCCCC1CC1C1CC1</smiles> 

To de uner $5 / 12$ ing

$22^{\text {Ll }}$ besteshne RR

$\sigma^{*}$ Mr mosth

cheshure 1861

urstaliner

the cuen Maturex.

AV' 1861 fo Nore 30/G 



\section{R $\mathrm{E} P O R T$}

OF THE DIRECTORS OF THE

\section{Agricultural Branch Railroad Corporation,}

For the Year Ending November 30, 1861.

Capital Stock, [authorized by law,

Number of shares of capital stock issued, - $\quad 1738$

Increase of capital since last Report, - - - $\quad$ None.

Capital paid in, per last Report, - - .

Capital paid in, since last Report, - -

Total amount of capital stock paid in, .

Funded debt, per last Report,

Funded debt, paid since last Report, - -

Funded debt, increase of, since last Report, -

Total present amount of funded debt, -

Floating debt, per last Report, : : : :
Floating debt, paid since last Report,

Floating debt, paid since last Report, : :
Floating debt, increase of, since last Report,

Total present amount of floating debt,

Total present amount of funded and floating debt,

Average rate of interest per annum, paid during the year,

Maximum amount of debts during the year,

Cost of Road and EQuipment.

For graduation and masoniry, per last Report,

For graduation and masonry, paid during the last year,

Total amount expended for graduation and masonry,

For wooden bridges, per last Report,

For wooden bridges, paid during the past year, -

Total amount expended for wooden bridges,

Total amount expended for iron bridges, (if any),

For superstructure, including iron, per last Report,

For superstructure, including iron, paid during the past

Total amount expended for superstructure, including iron,

For stations, buildings and fixtures, per last Report,

For stations, buildings and fixtures, paid during the past

Total amount expended for stations, buildings and fixtures,

For land, land-damages, and fences, per last Report,

For land, land-damages, and fences, paid during the past

Total amount expended for land, land-damages and

Fonces, -

For locomotives, paid during the past year,

Total amount expended for locomotives,

For passenger and baggage cars, paid during the past

Total amount expended for passenger and baggage cars,

For merchandise cars, per last Report, - - $\quad$ - $\quad$ None.

$\$ 108,675.50$

None.

$2,397.65$

None.

Not any.

$120,851.27$

159.17

9,15332

$\$ 480,000.00$

$202,088.00$

$97,500.00$

400.00

507.15

507.15

None.

$97,100.00$

$202,088.00$

$97,100.00$

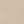

$23,235.60$

$9,153.32$

63.50

$23,302.10$

None.

None.

None.

None.

None.

None.

$108,675.50$

$2,397.65$

$121,010.44$ 
For merchandise cars, paid during the past year,

Total amount expended for merchandise cars,

For engineering, per last Report, - -

For engineering, paid during the past year,

Total amount expended for engineering,

For agencies and other expenses, per last Keport, [includ. ing interest and discount on bonds,]

For agencies and other expenses, paid during the past year,

Total amount expended for agencies and other expenses, [charged off to income account,]

[Interest on bonds, ]

Total cost of road and equipment, -

Amount of assets or property held by the corporation in addition to the cost of the road,

\section{Characteristics of Road.}

Length of road, [as authorised by charter,]

Length of single main track,

Length of double main track,

Length of branches owned by the Company, stating whether they have a single or double track,

Aggregate length of sidings, and other tracks, excepting main tracks and branches,

Weight of rail per yard, in main road, :

Weight of rail per yard, in branch roads, (specify the different weights per yard),

Maximum grade, with its length, in main road, .

Maximum grade, with its length, in branch roads, Total rise and fall in main road,

Total rise and fall in branch roads,

Shortest radius of curvature, with length of curve, in main road,

Shortest radius of curvature, with length of curve, in branch roads,

Total degrees of curvature in main road,

Total degrees of curvature in branch roads,

Total length of straight line, in main road,

Total length of straight line in branches, .

Aggregate length of wooden truss bridges,

Aggregate length of all other wooden bridges,

Aggregate length of iron bridges, -

Whole length of road unfenced on both sides,

Number of public ways crossed at grade,

Number of railroads crossed at grade,

Remarks,

Way stations for express trains,

Way stations for accommodation trains,

Flag stations,

Whole number of way stations,

Whole number of way stations,
Whole number of flag stations,

\section{DoIngs DURING The YeAr.}

Miles run by passenger trains,

Miles run by freight trains,

Miles run by other trains,

Total miles run,

Number of passengers carried in the cars,

Number of passengers carried one mile,

Number of tons of merchandise carried in the cars,

Number of tons of merchandise carried one mile,

Number of passengers carried one mile, to and from other roads.
None.

None.

None.

$9,475.93$

$9,475.93$

$86,225.41$

$7,200.18$

$93,425.59$

$17,016.96$

$76,409.63$

$350,423.57$

None.

28 364-1000 miles.

15 027-1000 miles.

None.

None.

953-1000 miles.

48,50 and $52 \mathrm{Jbs}$.

None.

$84 \mathrm{ft}$. per mile for 2000 $\mathrm{ft}$. near Marlboro' cen' ter, but no other grade over $58 \mathrm{ft}$. to the mile

None.

474 14-100 feet.

None.

738 feet for 110 feet.

None.

$870^{\circ} 02^{\prime}$

None.

8883.1000 miles.

None.

1101.2 feet.

176

None.

24

None.

None.

5

3

5

3 
Number of tons carried one mile, to and from other roads,

Rate of speed adopted for express passenger trains, including stops,

Average rate of speed actually attained by express passenger trains, including stops and detentions,

Rate of speed adopted for accommodation trains,

Rate of speed actually attained by accommodation trains, including stops and detentions,

Average rate of speed actually attained by special trains, including stops and detentions,

Average rate of speed adopted for freight trains, including stops,

Estimated weight in tons of passenger cars, (not including passengers), hauled one mile, - .

Estimated weiglit in tons of merchandise cars, (not including freight), hauled one mile,

\section{Expenditures for Working the Road.}

For repairs of road, maintenance of way, exclusive of wooden bridges, and renewals of iron,

For repairs of wooden bridges,

For wages of switchmen, average per month, $\$$

For wages of gate-keepers, average per month, $\$$

For wages of signal-men, average per month, $\mathbb{\$}$

For wages of watchmen, average per month, $\$$

Number of men employed, exclusive of those engaged in construction,

For removing ice and snow, (this item to include all labor, tools, repairs and extra steam power used),

For repairs of fences, gates, houses for signal men, gate. keepers, switchmen, tool.houses,

Total for maintenance of way,

\section{Motive Power and Cars.}

For repairs of locomotives,

For new locomotives, to cover depreciation

For repairs of passenger cars, -

For new passenger cars, to cover depreciation, -

For repairs of merchandise cars, -

For new merchandise cars, to cover depreciation,

For repairs of gravel and other cars,

Total for maintenance of motive power and cars,

Number of engines,

Number of passenger cars,

Number of baggage cars: .

Number of merchandise cars,

Number of gravel cars,

Miscellaneous.

For fuel used by engines during the year, viz. : -

Wood, number of cords,

Cost of the same,

Coal, number of tons, (reckoning 2,240 lbs, to the ton,) ('ost of same,

For oil used for cars and engines, -

For waste and other material for cleaning,

For salaries, wages, and incidental expenses, chargeable to passenger department,

For salaries, wages, and incidental expenses, chargeable to freight department,

For gratuities and damages,

For taxes and insurance,

For ferries,

For repairs of station buildings, aqueducts, fixtures, furniture,

For renewals of iron, including laying down,

Nor new iron laid down, deducting the value of old iron taken up,
To be answered by Bos

ton \& Worcester Rail.

road Company.

Operated by the Boston

\& Worcester Railroad

Co., since December,

1855 , under a lease on

file in the Secretary's

office of the Common:

wealth of Massachu.

setts. 
For amount paid other companies, in tolls for passengers and freight carried on their roads, specifying each company,

For amount paid other companies, as rent for use of their roads, specifying each company,

For salaries of president, treasurer, superintendent, law expenses, office expenses of the above offices, and all other expenses, not included in any of the foregoing items,

Total Miscellaneous,

Total expenditures for working the road, .

Total amount of interest paid during the year, .

\section{INCOME DURING THE Y FAR.}

For Pussengers :-

1. On main road, including branches owned oy company,

2. To and from other roads, specifying what,

For Freight:-

1. On main road and branches owned by company,

2. To and from other connecting roads,

U. S. Mails,

Rents,

Total income,

Net earnings, after deducting expenses,

\section{Dividends.}

6 per cent. Total, [on $\$ 50,000$ guarantied stock,]

Surplus not divided, . - . .

Surplus last year, : $\quad$ - : : : $\quad$ :

Total surplus,

Estimated Depreciation Beyond the Reńewals, viz :

Road and bridges,

Buildings,

Engines and cars, -

\section{Mortgage Debts.}

Amount of debts secured by mortgage of road and franchise, or any property of the corporation, per last Report,

Mortgage debt paid since last Report,

Mortgage debt, increase of, since last Report.

Total present amount of mortgage debt, -

Number of mortgages on road and franchise, or any property of the Corporation,
$\$ 12,007.45$ paid as rent

by the Boston \& Wor-

cester Railroad Co.

To be answered by Boston \& Worcester Railroad $\mathrm{Co}$.

\section{$\$ 97,500.00$}

400.00

None.

$97,100.00$

One.

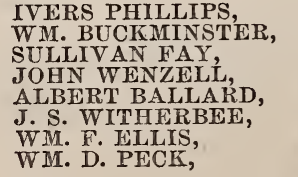

IVERS PHILLIPS, SULLIVAN FAY JOHN WENZELL J. S. WITHERBEE,

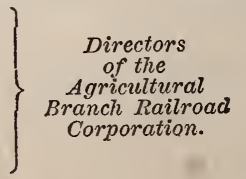

Middlesex, ss. December 17th, 1861. Then personally appeared Ivers Phillips, Wm. Buckminster, Sullivan Fay, John Wenzell, Albert Ballard, J. S. Witherbee, Wm. F. Ellis, and severally made oath to the truth of the foregoing statement by them subscribed. Before GEO. E. JOHNSON, Justice of the Peace.

Worcester, ss. December 17th, 1861. Then personally appeared Wm. D. Peck, and made oath to the truth of the foregoing statement by him subscribed. 


\section{AMHERST, RELCHERTOWN \& PALMRR}

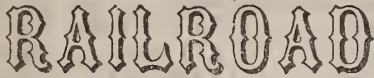

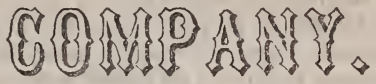

REPORT OF THE AMHERST, BELCHERTOWN AND PALMER RAILROAD CORPORATION FOR THE YEAR

ENDING NOVEMBER 30, 1861.

(To be returned to the Secretary of the Commonwealth, together with 1,000 printed copies of the same, on or before the first Wednesday in January next. General Statutes,

Chap. 63, Sections 132 to 135 )

By an Act of the Legislature, approved by the Governor, on the Twenty-Fifth day of March, A. D. 1858, the Amherst and Belchertown Kailroad property, Real and Personal, was sold at public auction, under provision of two Mortages upon their property, made by authority of said Company to secure the payment of Bonds issued by said Company, and purchased by the holders of the Bonds, and a Company organized by the name of Amherst, Belchertown and Palmer Railroad Company, agreeably to said Act, with a capital stock of eighty-five thousand dollars, or 850 shares, all paid in, which is the cost of the Real and Personal property of the said Amherst, Belchertown and Palmer Railroad Company.

Total cost of road and equipment as above stated,

Amount of assets or property held by $t \hbar_{\Lambda}$ e corporation in addition to the cost of the road, - Total present amount of debt, for locomotive, - -

A verage rate of interest per annum, paid during the year,

85.000

\subsection{0}

4,000

6 per cent.

19 50-100 miles.

None.

None.

about 2000 feet.

53 lbs.

$67 \mathrm{ft}$. for about $3-4$ mile.

Total rise and fall in main road,

Maxımum grade, with its length, in main road, 
Shortest radius of curvature, with length of curve, in main road,

Total degrees of curvature, in main road, -

Total length of straight line, in main road,

Aggregate length of wooden truss bridges, - "

Aggregate length of all other wooden bridges,

Aggregate length of iron bridges, -

Whole length of road unfenced on both sides,

Number ot public ways crossed at grade, -

Number of railroads crossed at grade,

Remarks;

Way stations for express trains, - :

Way stations for accommodation trains, -

Flag stations, - $\quad$ - -

$500 \mathrm{ft}$. radius, $400 \mathrm{ft}$. $10 \mathrm{ng}$

$495^{\circ}$

$14 \quad 5-8$ miles

375 feet.

1.100 feet.

None.

None.

18

One.

No express trains.

Three.

Two.

DOINGS DURING THE TEAR.

Miles run by passenger trains,-all mixed trains,

Total miles run ied in the cars, -

Number of passengers carried in the cars,

Number of tons of merchandise carried in the cars,

Number of tons of merchandise carried one mile,

Number of passengers carried one mile, to and from other roads,

Number of tons carried one mile, to and from other roads,

Rate of speed adopted for express passenger trains, including stops, -no express trains run, -

Rate of speed adopted for accommodation trains, -

Rate of speed actually attained by accommodation trains, including stops and detentions,

Estimated weight in tons of passenger cars (not including passengers,) hauled one mile,

Estimated weight in tons of merchandise cars (not including freight,) hauled one mile,

104.485

71.050

20 miles per hour.

20 miles per hour.

356.160

231.420

EXPENDITURES FOR WORKING THE ROAD.

For repairs of road, maintenance of way, exclusive of wooden bridges, and renewals of iron,

For repairs of wooden bridges,

For wages of watchmen, average per month, $\$ 26.00$,

Number of men employed, exclusive of those engaged in construction, 18.

For removing ice and snow, (this item to include all labor, tools, repairs, and extra steam power used,)

Total for maintenance of way, -

MOTIVE POWER AND CARS.

For repairs of locomotives, -

For new locomotives, to cover depreciation,

1000.00

For repairs of passenger and merchandise cars,

533.23

For new passenger cars, to cover depreciation, 
For new merchandise cars, to cover depreciation, - None.

For repairs of gravel and other cars,

Total for maintenance of motive power and cars,

Nothing.

Number of engines,

- Two.

Number of passenger cars, - $\quad: \quad: \quad-$ Two

Number of baggage cars, - . - . - . Two

Number of merchandise cars, - - - - Ten.

MISCELIANEOUS.

For fuel used by engines during the year, viz: wood, by contract,

For oil used by cars and engines, -

For waste and other material for cleaning, - _ $\quad$ - 86.67

For salaries, wages and incidental expenses, chargeable to passenger department, - -

For salaries, wages and incidental expenses, chargeable to freight department, - - -

For gratuities and damages, - - - -

Car service, - : : : : : :

For repairs of station buildings, acqueducts, fixtures, furniture, - $\quad-\quad$ - $\quad$ - $\quad$ - 92.37

For renewals of iron, including laying down, $\quad-1.090 .38$

For amount paid other companies, in tolls for passengers and freight carried on their roads, specifying each company, Western $\mathrm{R}, \mathrm{R}$. -

N. L. N. Rail Road, - -
For amount paid other companies, as rent for the use of their roads, specifying each company, N. L. N. R. R. Co. - - - - -

For salaries of president, treasurer, superintendent, law expenses, office expenses of the above offices, and all other expenses not included in any of the foregoing items. Treasurer's salary, - .

Total expenditures for working the road, 2.350 .77 2.350 .77

Nothing.

248.45

1.154 .27

7.286 .36

39.15

120.00

$\$ 1.921 .76$

Total amount of interest paid during the year,

INCOME DURING THE YEAR.

For Passengers:-

1. On main road, including branches owned by company,

2. To and from other roads, specifying what,

9.912.66

For Freight:-

1. On main road and branches owned by company,

2. To and from other connecting roads,

U. S. Mails,

Rents 25.00, Express 830.23, interest 73.98,

Total income,

14.115 .56

16.646 .08

20.025 .03

295.00

25.320 .03

$-\quad-26.017 .43$

- Surplus as per report 1860, - - - - $\quad$ - 2.301 .28

Niet earnings after deducting Expenses,

28.318.71

2.998 .68

* Expended as reported above, for Iron and payment towards new Engine. 


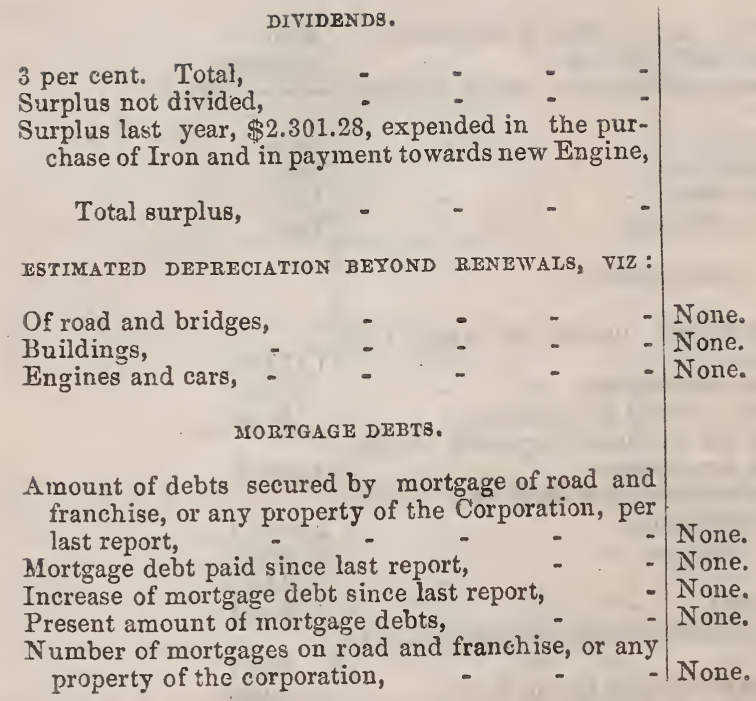

No accidents have occurred during the year.

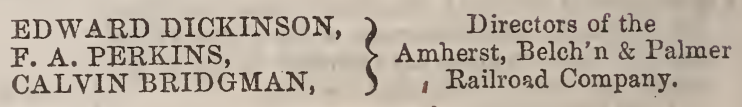

H $\triangle M P D E N$, ss. December 27, 1861. Personally appeared the above named Edward Dickinson, F. A. Perkins, and Calvin Bridgman, and made oath that the foregoing return by them subscribed, is true, according to their best knowledge and belief. Before me,

Danirl Granger, Justice of the Peace. 


\title{
R $\mathrm{E} P$ P $\mathrm{T}$
}

OF THE DIRECTORS OF THE

\section{Boston, Barre \& Gardner Railroad Corporation,}

\author{
For the Year Ending November 30, 1861.
}

\begin{tabular}{l}
\hline Capital Stock, \\
Number of shares of capital stock issued, \\
Increase of capital since last Report, \\
Capital paid in, per last Report, \\
Capital paid in, since last Report, \\
Total amount of capital stock paid in, \\
Funded debt, per last Report, \\
Funded debt, paid since last Report, \\
Funded debt, increase of, since last Report, \\
Total present amount of funded debt, \\
Floating debt, per last Report, \\
Floating debt, paid since last Report, \\
Floating debt, increase of, since last Report, \\
Total present amount of floating debt, \\
Total present amount of funded and floating debt, \\
Average rate of interest per annum, paid during the year, \\
Maximum amount of debts during the year,
\end{tabular}

Cost of Road and Equipment.

For graduation and masonry, per last Report,

For graduation and masonry, paid during the past year,

Total amount expended for graduation and masonry,

For wooden bridges, per last Report,

For wooden bridges, paid during the past year,

Total amount expended for wooden bridges,

Total amount expended for iron bridges, (if any),

For superstructure, including iron, per last Report,

For superstructure, including iron, paid during the past year,

Total amount expended for superstructure, including iron,

For stations, buildings and fixtures, per last Report,

For stations, buildings and fixtures, paid during the past year,

Total amount expended for stations, buildings and fixtures,

For land, land-damages, and fences, per last Report,

For land, land-damages, and fences, paid during the past

Total amount expended for land, land-damages and fences,

For lncomotives, per last Report,

For locomotives, paid during the past year,

Total amount expended for locomotives,

For passenger and baggage cars, per last Report,

For passenger and baggage cars, paid during the past

Total amount expended for passenger and baggage

For merchandise cars, per last Report, -

$\$ 1,000,000$

No part of Road constructed. 
For merchandise cars, paid during the past year,

Total amount expended for merchandise cars,

For engineering, per last Report, - -

For engineering, paid during the past year; :

Total amount expended for engineering,

For agencies and other expenses, per last Report,

For agencies and other expenses, paid during the past year,

Total amount expended for agencies and other expenses,

Total cost of road and equipment,

Amount of assets or property held by the corporation in addition to the cost of the road,

\section{Characteristics of Road.}

Length of road, - - - - -

Length of single main track,

Length of double main track,

Length of branches owned by the Company, stating whether they have a single or double track,

Aggregate length of sidings, and other tracks, excepting main tracks and branches,

Weight of rail per yard, in main road,

Weight of rail per yard, in branch roads, (specify the different weights per yard),

Maximum grade, with its length, in main road, -

Maximum grade, with its length, in branch roads,

Total rise and fall in main road,

Total rise and fall in branch roads, -

Shortest radius of curvature, with length of curve, in

main road, - -
Shortest radius of curvature, with length of curve, in branch roads,

Total degrees of curvature in main road,

Total degrees of curvature in branch roads,

Total length of straight line, in main road,

Total length of straight line in branches,

Aggregate length of wooden truss bridges,

Aggregate length of all other wooden bridges,

Aggregate length of iron bridges, -

Whole length of road unfenced on both sides,

Number of public ways crossed at grade,

Number of railroads crossed at grade,

Remarks, - - -
Way stations for express trains, -

Way stations for accommodation trains,

Flag stations,

Whole number of way stations,

Whole number of flag stations,

\section{DoIngs DURING the Year.}

Miles run by passenger trains,

Miles run by freight trains,

Miles run by other trains,

Total miles run,

Number of passengers carried in the cars,

Number of passengers carried one mile, -

Number of tons of merchandise carried in the cars,

Number of tons of merchandise carried one mile,

Number of passengers carried one mile, to and from other roads.

Number of tons carried one mile, to and from other roads,

Rate of speed adopted for express passenger trains, including stops, 
Average rate of speed actually attained by express passenger trains, including stops and detentions,

Rate of speed adopted for accommodation trains,

Rate of speed actually attained by accommodation trains,

including stops and detentions,
Average rate of speed actually attained by special trains, including stops and detentions,

Average rate of speed adopted for freight trains, including

Estimated weight in tons of passenger cars, (not includ. ing passengers), hauled one mile, -

Estimated weight in tons of merchandise cars, (not including freight), hauled one mile,

Expenditures for Working the Road.

For repairs of road, maintenance of way, exclusive of wooden bridges, and renewals of iron,

For repairs of wooden bridges,

For wages of switchmen, average per month, $\$$

For wages of gate-keepers, average per month, $\$$

For wages of signal-men, average per month, $\$$

For wages of watchmen, average per month, $\$$

Number of men employed, exclusive of those engaged in construction,

For removing ice and snow, (this item to include all labor, tools, repairs and extra steam power used),

For repairs of fences, gates, houses for signal men, gatekeepers, switchmen, tool-houses,

Total for maintenance of way,

\section{Motive Power and Cars.}

For repairs of locomotives,

For new locomotives, to cover depreciation, -

For repairs of passenger cars, -

For new passenger cars, to cover depreciation, -

For repairs of merchandise cars, - :

For repairs of gravel and other cars,

Total for maintenance of motive power and cars,

Number of engines,

Number of passenger cars,

Number of baggage cars,

Number of merchandise cars,

Number of gravel cars,

Miscellaneous.

For fuel used by engines during the year, viz. : -

Wood, number of cords, Cost of the same,

Coal, number of tons, (reckoning 2,240 lbs. to the ton,) Cost of same, : :
:

For oil used for cars and engines, - -

For waste and other material for cleaning,
For salaries, wages, and incidental expenses, chargeable to passenger departinent,

For salaries, wages, and incidental expenses, chargeable to freight department,

For gratuities and damages,

For taxes and insurance, -

For ferries, - - : - :

For repairs of station buildings, aqueducts, fixtures, furniture,

For renewals of iron, including laying down, -

Nor new iron laid down, deducting the value of old iron taken up,

For amount paid other companies, in tolls for passengers and freight carried on their roads, specifying each company, 
For amount paid other companies, as rent for use of their roads, specifying each company,

For salaries of president, treasurer, superintendent, law expenses, office expenses of the above offices, and all other expenscs, not included in any of the foregoing items,

Total Miscellaneous,

Total expenditures for working the road, -

Total amount of interest paid during the year, -

INCOME DURING THE YEAR.

For Passengers :-

1. On main road, including branches owned by com. pany,

2. To and from other roads, specifying what,

For Freight:-

1. On main road and branches owned by company,

2. To and from other connecting roads, U. S. Mails, Rents,

Total income,

Net earnings, after deducting expenses, : :

per cent. Total, Surplus not divided, Surplus last year,

Total surplus,

\section{Dividends.}

Estimáted Depreciation Beyond the Renewals, viz :

Of road and bridges,

Buildings,

Engines and cars, :

\section{Mortgage Debts.}

Amount of debts secured by mortgage of road and franchise, or any property of the corporation, per last Report,

Mortgage debt paid since last Report,

Increase of mortgage debt since last Report.

Present amount of mortgage debts,

Number of mortgages on road and franchise, or any property of the Corporation,

The Boston, Barre \& Gardner Railroad Company, respectfully represent that they have made no progress towards the construction of said road since their last Report.

\begin{tabular}{|c|c|}
\hline $\begin{array}{l}\text { JOHN BROOKS, } \\
\text { REJOICE NEWTON, } \\
\text { SAMUEL DAVIS, } \\
\text { HORATIO N. TOWER, } \\
\text { GEO. T. RICE, } \\
\text { D. S. MESSINGER, } \\
\text { J. S. HOLT, }\end{array}$ & $\begin{array}{l}\text { Directors of the } \\
\text { Boston, Barre \& Gardner } \\
\text { Railroad Corporation. }\end{array}$ \\
\hline
\end{tabular}

Worcester, ss., December 28, 1861. Then personally appeared John Brooks, Rejoice Newton, Samuel Davis, Horatio N. Tower, George T. Rice, D. S. Messinger, and severally made oath to the truth of the foregoing statement by them subscribed.

Before

JOAB S. HOLT, Justice of the Peace.

Worcester, ss., Dec. 28, 1861. Then personally appeared J. S. Holt, and made oath to the truth of the foregoing statement by him subscribed.
Before me,
P. C. BA.CON, Justice of Peace. 


\section{ANNUAL REPORT}

O F T H E

\section{BOSTON AND CHELSEA RAILROAD}

TO TH E

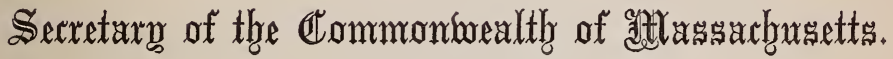

FOR THE YEAR ENDING NOVEMBER 30th, 1861.

CHARLESTOWN :

PRINTED BY W. W. WHEILDON. 

O F THE

\section{BOSTON AND CHELSEA RAILROAD.}

F'or the Year ending November 30th, 1861.

Report of the Boston and Chelsea Railroad Company, under General Statutes, Chapter 6.8 Sects. $149,144$.

\section{Condition of the Company.}

Capital stock, fixed by charter, - - Capital stock, as voted by the company, Capital stock paid in, in cash, - - Capital stock paid in, in work and materials, by contractors and others,

Funded debt, Floating debt, - $\quad-\quad$ - $\quad$ - $\quad$ -

Amount of above debt secured by mortgage of the road and franchise, or any property belonging to the corporation, or standing in its name,

Number of mortgages on road and franchise, or any property of the corporation, specifying the number and amount of mortgages on road and franchise, and each kind of property,

Amount of assets on hand, exclusive of the road and equipment, and exclusive of all property on hand, used, or which is to be used, in running the road and keeping it in repair,

Cost of the RoAd.

Amount expended for labor in excavating for the track, laying foundations and rails,

Amount expended in timber for foundation, -

Amount expended for iron and other metal for rails, chairs, spikes, or other articles, used in building the road,

Amount expended for paving,

Amount expended for paving stones, -

Amount expended for engineering,

Amount expended for interest, salaries of officers during construction of road, and other expenses not included in any of the above items, which have been included, on the books of the company, in the cost of the road, not including items of equipment or running expenses, as mentioned below,

Total cost of road,

Amount included in the present and in past years, among the running expenses for estimated or actual depreciation of the road, -
$\$ 140,000 \quad 00$

$\$ 300,000 \quad 00$

The Road was built by contract for the above sum.

None.

66

66

None.

None.

None.

This Road was built by contract for the gross sum of $\$ 140$,000 , including all expenses. 


\section{Cost of Equipment.}

Number of cars and cost, - -

Number of horses and cost, - _ -

Cost of omnibuses, sleighs and other vehicles, excepting cars, owned by the company, -

Cost of land and buildings thereon when purchased,

Cost of buildings used for offices, stables, \&c., erected by the company, or standing on land not owned by the company,

Cost of other articles of equipment, (specifying what,)

Total cost of equipment,

Amount included in the present and in past years in the running expenses for estimated or actual depreciation of any of the above items,

Net amount at which the equipment stands charged on the books of the company,

Characteristics of the Road.

Length of single main track,

Length of double main track, - _ _ -

Total length of road, - - - - -

Length of branches owned by the company, stating whether they have a single or double track,

Aggregate length of switches, sidings, turnouts and other track, excepting main track and branches,

Total length of rail

Weight of rail used, per yard, (specifying whether of cast or rolled iron,)

Maximum grade, per mile on road, with length of grade,

Shortest radius of curvature, with length of curve,

Greatest length of single track on road between two turnouts, -

Total length of main track which is paved, -

\section{Doings DURING the Year.}

Total number of miles run during the year, -

Number of passengers carried in the cars, -

Rate of speed adopted, including stops and detentions,

Rate of speed actually attained, including stops and detentions,

Number of persons employed, regularly, (specifying the occupations of each,)

Total number of trips run during the year, -

Average number of passengers each trip,
This Road is under lease to the Malden and Melrose Railroad Co., who furnish the entire equipment.

5,189 feet.

6,302 "

11,491 “

None.

862 feet.

16,040 feet.

56 lbs., wrought iron.

$184.8 \mathrm{ft}$., len. $240 \mathrm{ft}$.

Rd. $200 \mathrm{ft}$. len. $197 \mathrm{ft}$

1622 feet.

The whole track is \} paved except Chelsea Bridge.

Road under lease as previously stated. 
EXPENDITURES FOR WORKING tHE ROAD.

For repairs of road, including repairs of foundation, renewals of iron, and renewals of pavement,

For general repairs, including repairs of cars, omnibuses and harnesses, and for shoeing horses,

For repairs of real estate, including repairs of buildings used as stables, offices, or for any other purposes, by the company,

For wages, including the wages of every person regularly employed, excepting the president, directors, superintendent and treasurer,

For interest,

For taxes and insurance, - $\quad$ - $\quad$ -

For tolls paid other companies for the right to pass over their roads,

For rent paid other companies for use of their roads,

For provender, - to include cost of hay, grain, straw, or other articles used for the food or bedding of horses,

For miscellaneous articles purchased during the year - such as harnesses, blankets, \&c., the use of which continues for one or more years - and not included in the cost of equipment,

For loss on horses - that is to say, the difference between the present estimated value of the horses owned by the company subtracted from the estimated value of those on hand at the commencement of the year, added to the cost of those purchased during the year; or if this is the first report of the company, then the difference between the estimated value of the horses on hand and their cost - giving the present av. estimated value of each horse,

For incidental expenses, - to include printing, president's, directors', treasurer's and superintendent's salaries, and all expenses other than those belonging to the actual working of the road,

For all other expenses,

For amount charged on the company's books during the year, for estimated or actual depreciation of the following property:-

Cars,

Horses,

Omnibuses,

Real Estate,

Road,

Other property,

Total,

Total expenses,
Road under lease, as previously stated. 


\section{Earnings.}

Received from passengers in cars and omnibuses, and for tickets sold,

From other roads, as toll or rent for use of road, From United States mails, - $\quad$ - $\quad$ For sales of manure, - - - - From other sources, - $\quad$ - $\quad$ - $\quad$ Total earnings, - $\quad$ - $\quad$ - $\quad$ - $\quad$ Net earnings, after deducting expenses, Surplus earnings of previous year, on hand, Net earnings, as above, Total surplus for payment of dividends, Dividends declared, during the year, - Total per centage of dividends, for the year, Present surplus,

\section{Miscellaneous.}

Increase during the year -

Of capital stock, as fixed by the charter, Of capital stock, as voted by the company, Of capital stock, paid in,

Increase of funded debt, during the year, Increase of floating debt, during the year, Decrease of funded debt, during the year, Decrease of floating debt, during the year, Increase of mortgage debt, during the year, Decrease of mortgage debt, during the year, Increase in cost of road, during the year, including amount charged for depreciation thereon,

Decrease in nominal cost of road, by amount charged for depreciation thereon,

Increase in cost of equipment, during the year, including amount charged for depreciation thereon,

Decrease in cost of equipment, by sale of any portion thereof, or by amount charged for depreciation,

List of accidents on road during the year, -
Received for rent from Oct. 1,1860 , to Oct. $1,1861, \$ 5,600$, which was distributed in two dividends of 4 per ce t. each on $\$ 70,000$ stock.

Leased as previously stated.

$\left.\begin{array}{l}\text { WM. W. WHEILDON, } \\ \text { J. W. EMERY, } \\ \text { ESTES HOWE, } \\ \text { JOSEPH H. CONVERSE, }\end{array}\right\} \begin{gathered}\text { Directors of } \\ \text { Boston and Chelsea } \\ \text { Railroad Co. }\end{gathered}$




\section{COMMONWEALTH OF MASSACHUSETTS.}

SUFFOLK, ss.

Boston, December 25, 1861.

Then personally appeared William W. Wheildon, J. W. Emery, Estes Howe, and J. H. Converse, and severally made oath that the foregoing statement by them signed, is true, according to the best of their knowledge and belief.

Before me,

J. M. PINKERTON, Justice of the Peace. 



\section{REPORT}

OF THE

\section{DIRECTORS}

OF THE

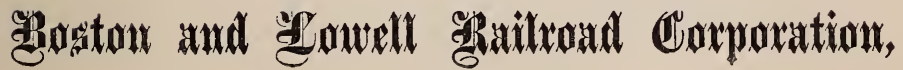

FOR T'HE YEAR ENDING NOVEMBER 30, 1861. 



\title{
REPORT
}

\author{
D I R E C T O R S
}

OF THE

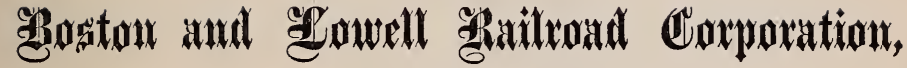

For the year ending November 30, 1861.

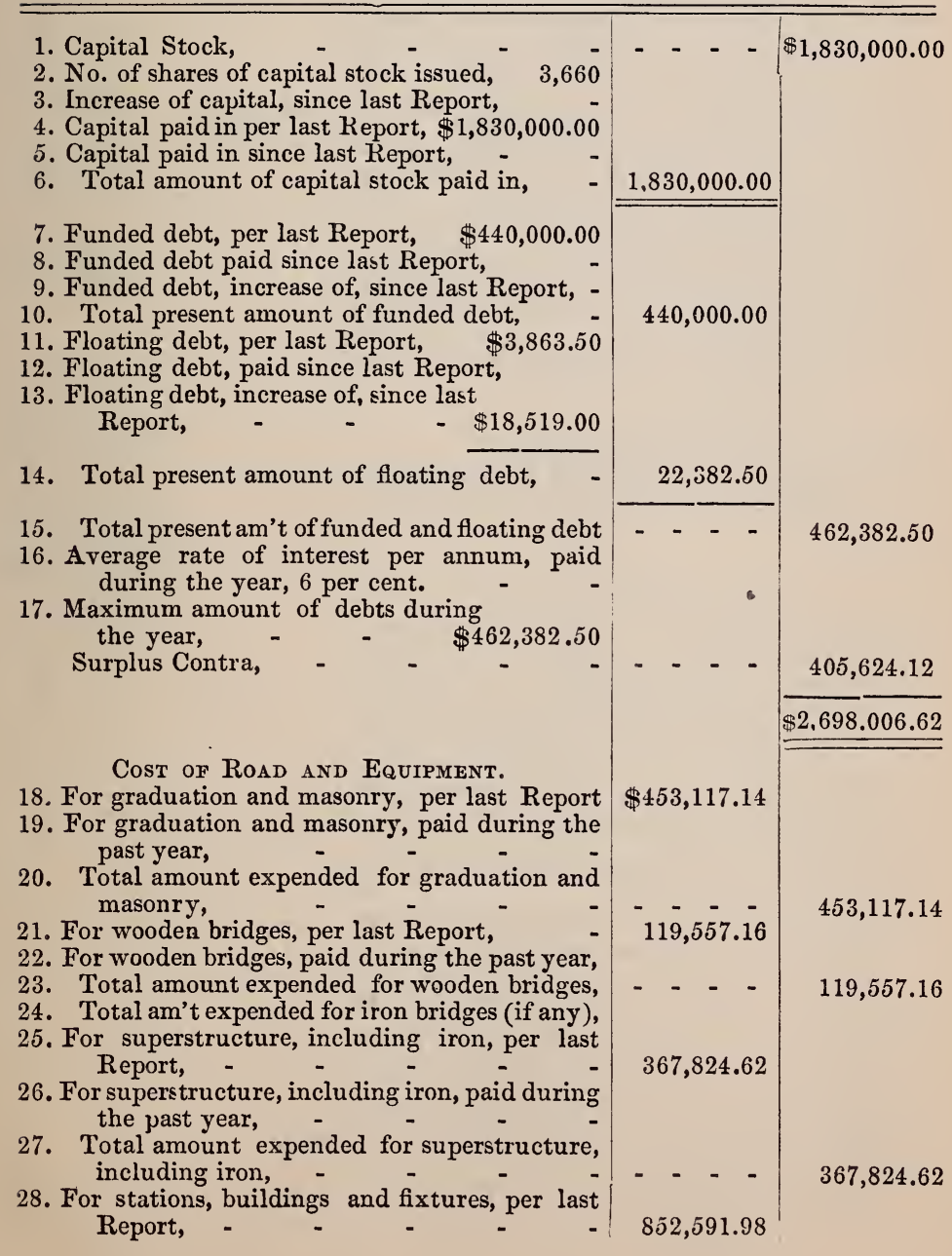


29. For stations, buildings and fixtures, paid during the past year,

30. Total amount expended for stations, buildings and fixtures,

31. For land, land-damages and fences per last Report, - - - - -

32. For land, land-damages and fences, paid during the past year,

33. Total amount expended for land, land-damages and fences,

34. For locomotives, per last Report,

35. For locomotives, paid during the past year, -

36. Total amount expended for locomotives, -

37. For passenger \& baggage cars, per last Report,

38. For passenger and baggage cars paid during the past year,

39 Total amount expended for passenger and baggage cars,

40. For merchandise cars, per last Report, -

41. For merchandise cars, paid during the past year

42. Total am't expended for merchandise cars,

43. For engineering, per last Report,

44. For engineering, paid during the past year, -

45. Total amount expended for engineering, -

46. For agencies and other expenses, per last Report

47. For agencies and other expenses, paid during the past year,

48. Total amount expended for agencies and other expenses,

49. Total cost of road and equipment, -

50. Amount of assets or property held by the Corporation in addition to the cost of the Road,

$\$ 404,797.46$

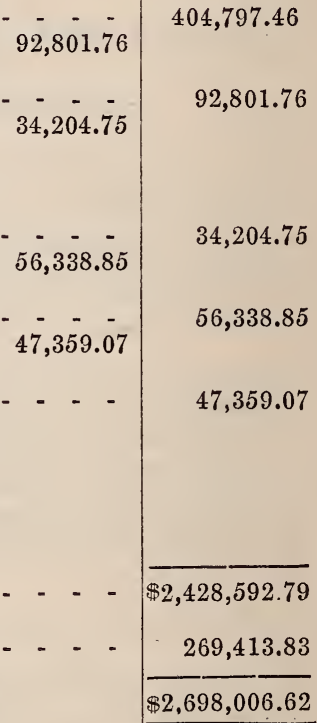

\section{Characteristics of Road.}

51. Length of road,

$-26^{3}$ miles.

52. Length of single main track, - none.

53. Length of double main track, $-26 \frac{3}{4}$ miles.

54. Length of branches owned by the Company, stating whether they have a single or double track, single. - - $1 \frac{3}{4}$ miles- $585 \mathrm{ft}$.

55. Aggregate length of sidings, and other tracks, excepting main tracks anả branches, 16 miles, $-3824 \mathrm{ft}$

56. Weight of rail, per yard, in main road, 56 to 63 lbs.,

57. Weight of rail, per yard, in branch roads, (specify the different weights per yard,) $56 \mathrm{lbs}$.,

58. Maximum grade, with its length, in main road, - $10 \mathrm{ft}$. per mile, $628-100$ miles.

59. Maximum grade, with its length, in branch roads, - - $54 \mathrm{ft}$. per mile, $5,000 \mathrm{ft}$.

60. Total rise and fall in main road, $18993-100 \mathrm{ft}$.

61 . Total rise and fall in branch roads, $7354-100 \mathrm{ft}$.

62. Shortest radius of curvature, with length of curve, in main road, $1,654 \mathrm{ft}$., $2,800 \mathrm{ft}$. radius,

(

$--$

$34,204.75$

- - -

$34,204.75$

$56,338.85$

$47,359.07$ 
63. Shortest radius of curvature, with length of curve, in branch roads, $662 \mathrm{ft} .1,957 \mathrm{ft}$. radius.

64. Total degrees of curvature, in main road, 665 degrees. -

65. Total degrees of curvature, in branch roads, 108 degrees.

66. Total length of straight line, in main road,

67. Total length of straight line, in branches, 1 mile, $1,811 \mathrm{ft}$.

68. Aggregate length of wooden truss bridges, $63 \mathrm{ft}$.

69. Aggregate length of all other wooden bridges, $3,577 \mathrm{ft}$.

70. Aggregate length of iron bridges, - none.

71. Whole length of road unfenced on both sides, none.

72. Number of public ways crossed at grade, none.

73. Number of railroads crossed at grade, none.

74. Remarks, - $\quad$ - $\quad$ - $\quad$ -

75. Way stations for express trains, - -

76. Way stations for accommodation trains, 9.

77. Flag stations, - $\quad-\quad \quad-\quad-\quad 13$.

78. Whole number of way stations, - -

79. Whole number of flag stations, - -

Doings During the Year.

80. Miles run by passenger trains, - $\quad 183,699$.

81. Miles run by freight trains, - $\quad 173,993$.

82. Miles run by other trains, - -

83. Total miles run, - - $\quad 357,692$.

84. Number of passengers carried in the cars, $608.325,-$
umber of passengers carried one mile, 85. Number of passengers carried one mile,
$7,670,441$. -

86. Number of tons of merchandise carried in the cars, - - - 370,372 .

87. Number of tons of merchandise carried one mile, - - - $6,272,401$.

88. Number of passengers carried one mile, to and from other roads, - $\quad$ - 2,639,060.

89. Number of tons carried one mile, to and from other roads, . - - $\quad 4,154,999$.

90. Rate of speed adopted for express passenger trains, including stops,

91. Average rate of speed actually attained by express passenger trains, including stops and detentions,

92. Rate of speed adopted for accommodation trains, - $\quad-\quad 25$ miles per hour.

93. Rate of speed actually attained by accommodation trains, including stops and detentions, - $\quad-\quad 25$ miles per hour.

94. Average rate of speed actually attained by special trains, including stops and detentions, - - 25 miles per hour.

95. Average rate of speed adopted for freight trains, including stops, 10 miles per hour.

96. Estimated weight in tons, of passenger cars (not including passengers) hauled one mile,

97. Estimated weight in tons of merchandise cars, (not including freight) hauled one mile, 
Expenditures for Working the Road.

98. For repairs of road, maintenance of way, exclusive of wooden bridges and renewals of iron.

99. For repairs of wooden bridges, -

100. For wages of switchmen av'ge per mo. $\$$

101. For wages of gate-keepers, av'ge pr. mo.\$

102. For wages of signal-men, av'ge per mo. \$

103. For wages of watchmen, av'ge per mo. \$

104. Number of men employed, exclusive of those engaged in construction, 337.

105. For removing ice and snow, (this item to include all labor, tools, repairs, and extra steam-power used,)

106. For repairs of fences, gates, houses for signalmen, gate-keepers, switchmen, tool-houses,

107. Total for maintenance of way, -

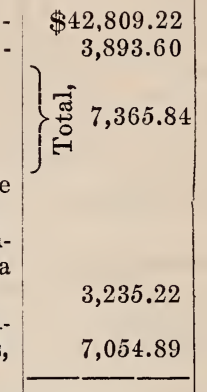

Motive Power and Cars.

108. For repairs of locomotives,

109. For new locomotives, to cover depreciation, -

110. For repairs of passenger cars,

111. For new passenger cars, to cover depreciation,

112. For repairs of merchandise cars,

113. For new merch. cars, to cover depreciation, -

114. For repairs of gravel and other cars,

115. Total maintenance motive power and cars, -

116. Number of engines, - - - - $\quad 21$

117. Number of passenger cars, - - $\quad$ - 27

118. Number of baggage cars, - - - 10

119. Number of merchandise cars, - - 602

120. Number of gravel cars, included above,

\section{Miscellanteous.}

121. For fuel used by engines during the year, viz. :

1. Wood, number of cords, 4,918. Cost of the same, - - - - 2. Coal, number of tons, (reckoning 2,240
lbs. to the ton,) 2,225 . Cost of same, -

122. For oil used by cars and engines, - - - - -

123. For waste and other material for cleaning, chargeable to passenger department,

125. For salaries, wages, and incidental expenses, chargeable to freight department, - -

126. For gratuities and damages, - - -

127. For taxes and insurance, - - - - -

129. For repairs of station-buildings, aqueducts, fixtures, furniture, -

130. For renewals of iron, including laying down,

131. For new iron laid down, deducting the value of old iron taken up,

132. For amount paid other companies, in tolls, for passengers and freight carried on their roads, specifying each company, 
133. For amount paid other companies, as rent for use of their roads, specifying each company, Lowell and Lawrence R.R., $\$ 15,028,20$; Salem and Lowell R.R., \$12,075.00; Stony Brook R.R., \$12,213.00,

134. For salaries of president, treasurer, superintendent, law expenses, office expenses of the above offices, and all other expenses not included in any of the foregoing items,

135. Total Miscellaneous, -

136. Total expenditures for working the road,

137. Total amount of interest paid during the year,

\section{Income During the Year.}

138. For Passengers :-

1. On main road, including branches owned

$$
\text { To and from other roads, - } \quad-\quad\}
$$

139. For Freight:-

1. On main road and branches owned by

2. To and from other connecting roads, $\}$

140. U. S. Mails, - - - - -

141. Rents, and Miscellaneous Receipts, -

142. Total income,

143. Net earnings after deducting expenses,

$\$ 178,233.90$

$\frac{12,592.87}{--.}$

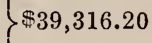

$\$ 39,316.20$

$\$ 213,585.02$

$320,318.74$

$26,341.73$

$\$ 346.660 .47$

$259,547.77$

$6,432.96$

$4,837.14$

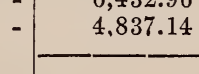

$\$ 449,051.77$

$\$ 102,391.30$

Dividends.

144. 7 per cent. Total, -

145. Surplus not divided, -

146. Surplus last year,

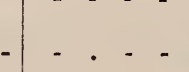

$128,100.00$

$431,332.82$

$\$ 303,232.82$

$\$ 405,624.12$

$50,325.00$

From which is to be deducted dividend, January 1, 1862,

$355,299.12$

Estimated Depreciation beyond the RenetwALs, VIz, :

148. Of road and bridges,

149. Buildings.

Kept good by repairs

150. Engines and Cars, $\}$ and renewals.

Mortgage Debts.

151. Amount of debts secured by mortgage of road and franchise, or any property of the Corporation, per last report,

152. Mortgage debt paid since last report,

153. Increase of mortgage debt since last report, -

154. Present amount of mortgage debts, -

155. Number of mortgages on road and franchise, or any property of the corporation, 
Accidents During the Year Ending Nov, 30, 1861.

1861.

Aug. 20. George Howland was thrown from the top of a freight train, by coming in contact with Hales Bridge, in Lowell, and received slight injuries.

Sept. 25. Michael T. Beecher was run over and killed, while walking upon the track in East Cambridge.

$$
\left.\begin{array}{l}
\text { F. B. CR(OWNINSHIELD, } \\
\text { J. G. ABBOTT, } \\
\text { WM. MINOT, JR., }
\end{array}\right\} \begin{gathered}
\text { Directors of the } \\
\text { Boston and Lowell } \\
\text { Railroad Corporation. }
\end{gathered}
$$

SuffoLk, ss. December 30, 1861. Then personally appeared F. B. Crowninshield, and J. G. Abbott, and severally made oath to the truth of the foregoing statement by them subscribed.

Before

J. Thos. Stevenson, Justice of the Peace. 


\section{REPOR'T}

OF THE

\section{DIRECTORS}

OF THE

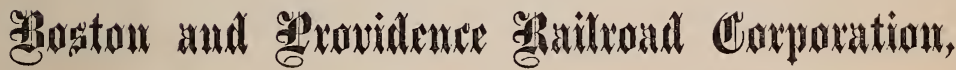

F0R T'HE YEAR ENDING NOVEMBER 30, 1861. 



\title{
REPORT
}

\author{
OF THE \\ D I R E C T O R S
}

OF THE

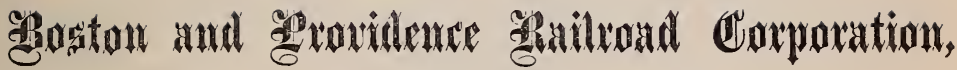

For the year ending November 30, 1861.

1. Capital Stock,
2. Number of shares of capital stock issued,
$\quad 31,600,-$
3. Increase of capital, since last Report,
4. Capital paid in per last Report,
5. Capital paid in since last Report,
6. Total amount of capital stock paid in,
7. Funded debt, per last Report,
8. Funded debt paid since last Report,
9. Funded debt, increase of, since last Report, -
10. Total present amount of funded debt,
11. Floating debt, per last Report,
12. Floating debt, paid since last Report,
13. Floating debt, increase of, since last Report,
14. Total present amount of floating debt,
15. Total present am't of funded and floating debt
16. Average rate of interest per annum, paid
during the year, 6 per cent.

17. Maximum amount of debts during the year, $\$ 162,720$.

Cost of Road and Equipment.

Sekonk Br. and Wharf, - $\$ 31,655.70$

New Track, India St., _ _ $\quad 13,190.28$

B. and P. Railroad, in R. I., - $\quad 150,000.00$

P. and W. R. R., on joint acc't, $399,904.90$

18. For graduation and masonry, per last Report

19. For graduation and masonry, paid during the past year,

20. Total amount expended for graduation and masonry.

21. For wooden bridges, per last Report.

22. For wooden bridges, paid during the past year,

23. Total amount expended for wooden bridges,

24. Total am't expended for iron bridges (if any),

25. For superstructure, including iron, per last Report,

26. For superstructure, including iron, paid during the past year,

27. Total amount expended for superstructure, including iron,

28. For stations, buildings and fixtures, per last Report,
$\$ 3,160,000.00$

$3,160,000.00$

$3,160,000.00$

$162,720.00$

$30,000.00$

$132,720.00$

$132,720.00$

$594,750.88$

$\$ 775,000.00$

$775,000.00$

$101,000.00$

$775,000.00$

$101,000.00$

$9,840.00$

$378,914.40$

$378,914.40$

$497,000.00$ 
29. For stations, buildings and fixtures, paid during the past year,

30. Total amount expended for stations, build-

ings and fixtures,
31. For land, land-damages and fences per last

Report,
32. For land, land-damages and fences, paid during the past year,

33. Total amount expended for land, land-damages and fenees, - $\quad$ - $\quad$ -

34. For locomotives, per last Report, - -

35. For locomotives, paid during the past year, -

37. For passenger \& baggage cars, per last Report,

38. For passenger and baggage cars paid during the past year,

39 Total amount expended for passenger and baggage cars,

40. For merchandise cars, per last Report,

$\$ 501,094.72$

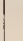

41. For merchandise cars, paid during the past year

42. Total am't expended for merchandise cars,

43. For engineering, per last Report, - -

44. For engineering, paid during the past year, -

45. Total amount expended for engineering, -

46. For agencies and other expenses, per last Report

47. For agencies and other expenses, paid during the past year,

48. Total amount expended for agencies and other expenses.

49. Total cost of road and equipment, - -

50. Amount of assets or property held by the Corporation in addition to the cost of the Road,

\section{Characteristics of Road.}

51. Length of road,

52. Length of single main track,

- 47 miles.

53. Length of double main track,

- 21 miles.

54. Length of branches owned by the Company, stating whether they have a single or double track, - - - - 7 miles, single.

55. Aggregate length of sidings, and other tracks, excepting main tracks and branches, $6 \frac{1}{2}$ miles, single,

56. Weight of rail, per yard, in main road, 56 to 60 lbs.,

57. Weight of rail, per yard, in branch road, (specify the different weights per yard,) $37 \frac{1}{2}$ to $60 \mathrm{lbs}$.,

58. Maximum grade, with its length, in main road, $34 \frac{1}{2} \mathrm{ft}$. per mile, $26,700 \mathrm{ft}$.

59. Maximum grade, with its length, in branch roads, - $5227-100 \mathrm{ft}$. per mile, 1,509 ft.

60 . Total rise and fall in main road, $50141-100 \mathrm{ft}$ per mile,

61. Total rise and fall in branch roads, 306 87-100 ft. per mile. -

62. Shortest radius of curvature, with length of curve, in main road, - $\quad-1,900 \mathrm{ft} ., 700 \mathrm{ft}$.
$105,300.00$

$\$ 497,000.00$

$501,094.72$

$44,100.00$

$58,000.00$

$95,000.00$

$58,000.00$

$95,000.00$

3, 160,00000

$240,197.68$ 
63. Shortest radius of curvature, with length of curve, in branch roads, - $\quad$ - $900 \mathrm{ft}$.

64. Total degrees of curvature, in main road, $342-12-60$ ó.

65. Total degrees of curvature, in branch roads, $416-14-60$ \%

66. Total length of straight line, in main road, $35 \frac{5}{8}$ miles,

67. Total length of straight line, in branches, 8 37-100 miles,

68. Aggregate length of wooden truss bridges, $2,086 \frac{1}{2} \mathrm{ft}$..

69. Aggregate length of all other wooden bridges, $1,520 \mathrm{ft}$.

70. Aggregate length of iron bridges, $\quad-299 \mathrm{ft}$.

71. Whole length of road unfenced on both sides, 4 miles,

72. Number of public ways crossed at grade, 42.

73. Number of railroads crossed at grade, 1.

74. Remarks,

75. Way stations for express trains, - 3 .

76. Way stations for accommodation trains, 27.

77. Flag stations, - $\quad-\quad-\quad-\quad-66$.

78. Whole number of way stations, - $\quad 27$.

79. Whole number of flag stations, - 6.

Doings During the Year.

80. Miles run by passenger trains, . - -

81. Miles run by freight trains, - - -

82. Miles run by other trains, - $\quad$ -

83. Total miles run, - - - -

84. Number of passengers carried in the cars, -

85. Number of passengers carried one mile, -

86. Number of tons of merchandise carried in the cars,

87. Number of tons of merchandise carried one mile

88. Number of passengers carried one mile, to and from other roads, - $\quad$ - $\quad$ -

89. Number of tons carried one mile, to and from other roads, .

90. Rate of speed adopted for express passenger trains, including stops, 29 miles per hour.

91. Average rate of speed actually attained by express passenger trains, including stops and detentions, - 29 miles per hour.

92. Rate of speed adopted fur accommodation trains, - - 22 miles per hour.

93. Rate of speed actually attained by accommodation trains, including stops and detentions, - $\quad$ - 22 miles per hour.

94. Average rate of speed actually attained by special trains, including stops and detentions, - $\quad$ - 22 miles per hour.

95. Average rate of speed adopted for freight trains. including stops, 12 miles per hour.

96. Estimated weight in tons, of passenger cars (not including passengers) hauled one mile,

$9,545,328$

97. Estimated weight in tons of merchandise cars, (not including freight) hauled one mile,

250,873

115,248

10.833

376,954

$1,013,533$

$13,314,545$

243,496

$7,877,680$

$\tilde{5}, 951.177$

3484,636 
Expenditures for Woring the Road.

98. For repairs of road, maintenance of way, exclusive of wooden and iron bridges.

Carried to Fund for repairs, - $\quad 2,732.00$

99. For repairs of wooden bridges, $\$ 2,253.00$ Carried to Fund, - _ _ $\quad 6,747.00$

100. For wages of switchmen av'ge per mo. $\$ 25.00$

101. For wages of gate-keepers. av'ge per mo. 25.00

102. For wages of signal-men, av'ge per mo. 25.00

103. For wages of watchmen, av'ge per mo. 33.67

104. Number of men employed, exclusive of those engaged in construction, $30 \tilde{\text {. }}$

105. For removing ice and snow, and amt. carried to Fund for removing snow,

106. For repains of fences, gates, houses, and amount carried to $\mathrm{F}$ und,

107. Total for maintenance of way, -

Motive Power and Cars.

108. For repairs of locomotives, - $\$ 15,114.38$

109. For new locomotives, and amount

carried to Fund, - $\quad$ - $8,885.62$

$24,000.00$

110. For repairs of passenger cars, - $\quad 11,609.59$

111. For amount carried to Fund, to cover depreciation, - - $\quad$ - 890.41

112. For repairs of merchandise cars, $4,395.72$

113. For new merchandise cars, and amount carried to Fund, - $\quad$ - 9,604.28

114. For repairs of gravel and other cars, - -

115. Total for maintenance of motive power and cars, -

116. Number of engines, - $\quad$ - $\quad$ - $\quad$ - 24

117. Number of passenger cars, - - $\quad-29 \frac{1}{2}$

118. Number of baggage cars, - $\quad-\quad 9$

119. Number of merchandise cars : 199 8-wheel, and 10 4-wheel, - $\quad$ - $\quad$ - $\quad$ -

120. Number of gravel cars, - $\quad$ - 20

Miscellaneous.

121. For fuel used by engines during the year, viz. :

1. Wood, 1,062 cords. Cost of the same, - - - $\$ 5,310.00$

2. Coal, 5.121 tons, (reckoning $2,240 \mathrm{lbs}$. to the ton,) including Water, - $\quad$ - 29,702.52

122. For oil used by cars and engines, - - -

123. For waste and other material for cleaning, -

124. For salaries, wages and incidental expenses, chargeable to passenger department,

125. For salaries, wages, and incidental expenses, chargeable to freight department, - -

126. For gratuities and damages, -

127. For taxes and insurance, - - -

$9,000.00$

$12,020.09$

$1,500.00$

$3,000.00$

$\$ 68,520,09$

$12,500.00$

$14,000.00$

$50,500.00$

35,012.0์2

4,172.89

985.84

$43,615.37$

$52,965.68$

$3,000.00$

$9,172.64$ 
128. For transportation Mail.

129. For repairs of station-buildings, aqueducts, fixtures, furniture and fund, -

130. For renewals of iron, i'cluding laying down, 131.

132. For amount paid other companies, in tols, for passengers and freight carried on their roads, specifying each company,

133. For amount paid other companies, as rent for use of their roads, specifying each company,

134. For salaries of president, treasurer, superintendent, law expenses, office expenses of the above offices, and all other expenses not included in any of the foregoing items,

135. Total Miscellaneous, -

136. Total expenditures for working the road, -

137. Total amount of interest paid during the year,

Total expenses, Fund for renewal and interest,

Income During the Year.

138. For Passengers :-

1. On main road, including branches owned by company,

2. To and from other roads,

139. For Freight:-

1. On main road and branches owned by

2. To and from other connecting roads,

140. U. S. Mails,

S. Mails, - $\quad$ - $\$ 8,568.75$

Express business, - $\quad$ - $\quad 11,701.12$

141. Rents,

Interest \& - $\quad-\quad \quad-\quad 9,159.82$

$9,159.82$
$9,136,93$

142. Total income,

$-$

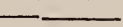

143. Net earnings after deducting expenses,

Dividends.

144. 8 per cent. Total, -

145. Surplus not divided, -

146. Surplus last year,

147. Total surplus,
$\$ 619.75$

$22,000.00$

$16,000.00$

$9,877.6 \tilde{0}$

$\$ 197,422.34$

$316,442.43$

$8,113.20$

$324,555.63$

Estimated Depreciation beyond the RenewALS, VIZ :

148. Of road and bridges. See Rep. Bridges, above, 149. Buildings. See Rep. Stations, \&c., above, 150. Engines and Cars. See Rep. Engines and Cars, above, -

\section{Mortgage Debts.}

151. Amount of debts secured by mortgage of road and franchise, or any property of the Corporation, per last report,

152. Mortgage debt paid since last report, - 1 - Increase of mortgage debt since last report, - None.

154. Present amount of mortgage debts, -

155. Number of mortgages on road and franchise, or any property of the corporation, 
Accidents During the Year Ending Nov. 30, 1861.

1861.

Jan. 23. Owen Derry, laborer, died at Hospital from injuries received by falling from gravel train.

Feb'y 11. Wm. A. Watts, slightly injured by jumping from train while in motion,

Mar. 25. Geo. W. Wilson, printer, slightly injured at Pautucket Station, in attempting to get on train while in motion.

June 20. Margaret Leubec, instantly killed while walking on track near Roxbury Station. Verdict-Corporation blameless.

Nov. 19. Edward McColligan, died at Hospital from injuries received at Boston Station, in jumping from train while in motion.

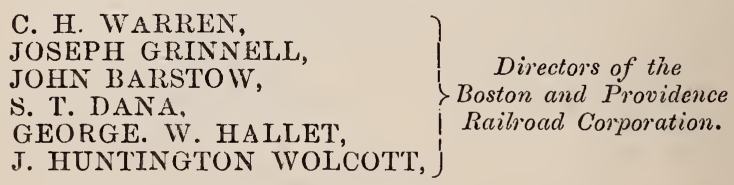

Directors of the

$>$ Boston and Providence Railroad Corporation.

Sufrolk, ss. December 27, 1861. Then personally appeared C. H. Warren, Joseph Grinnell, John Barstow, S. T. Dana, Geo. W. Hallet, and J. Huntington Wolcott, and severally made oath to the truth of the foregoing statement by them subscribed.

Before

E. Pickering, Justice of the Peace. 
TWENTY-SEVENTH ANNUAL REPORT

OF TH

\section{BOSTON AND MAINE RAIL-ROAD.}

Report of the Directors of the Boston and Maine Railroad Corporation, for the year ending November 30, 1861.

1 Capital stock, - $\quad$ - $\quad-$ -

2 Number of shares of capital stock issued,

3 Increase of capital, since last report, -

4 Capital paid in, per last report, -

5 Capital paid in since last report, -

6 Total amount of capital stock paid in, -

7 Funded debt, per last report,

8 Funded debt paid since last report.

9 Funded debt, increase of, since last report,

10 Total present amount of funded debt, -

11 Floating debt, per last report, -

12 Floating debt paid since report, -

13 Floating debt, increase of, since last report,

14 Total present amount of floating debt, -

15 Total present amount of funded and floating debt,

16 Average rate of interest per annum, paid during the year,

17 Maximum amount of debts during the year,

\section{Cost of Road and Equipment.}

18 For graduation and masonry, per last report, -

19 For graduation and masonry, paid during the

20 Total amount expended for graduation and masonry,

21 For wooden bridges, per last report, -

22 For wooden bridges, paid during the past year, -

23 Total amount expended for wooden bridges,

24 Total amount expended for iron bridges, (if any)

25 For superstructure, including iron, per last report,

26 For superstructure, including iron, paid during the past year, -

27 Total amount expended for superstructure, including iron,

28 For stations, buildings and fixtures, per last report, -

29 For stations, buildings and fixtures, paid during the past year,

30 Total amount expended for stations, buildings and fixtures, - $\quad$ - $\quad$ - $\quad$ -
$\$ 4,155,700 \quad 00$

41,557

Nothing.

$4,076,97452$

Nothing.

Nothing.

66

66

66

92,72000

28,06442

22,00000

86,65558

$86,655.58$

6 per cent.

114,72000

882,06740

$2,000 \quad 00$

371,46855

884,06740

Nothing.

None.

984,52389

Nothing.

98452389

520,72278

Nothing.

371,46855

884


31 For land, land-damages and fences, per last report,

32 For land, land-damages and fences, paid during

33 Total amount expended for land, land-damages and fences, - - -

34 For locomotives, per last report, - -

35 For locomotives, paid during the past year, $[\$ 7500$, sold $\$ 4000$, charged for depreciation, $\$ 2200$, ] -

36 Total amount expended for locomotives,

37 For passenger and baggage cars, per last report,

38 For passenger and baggage cars, paid during the past year, [nothing, but charged for deprec'n,]

39 Total amount expended for passenger and baggage cars, - - - - -

40 For merchandise cars, per last report, - -

41 For merchandise cars, paid during the past year,

42 Total amount expended for merchandise cars, -

43 For engineering, per last report, -

44 For engineering, paid during the past year, -

45 Total amount expended for engineering, -

46 For agencies and other expenses, per last report,

47 For agencies and other expenses, paid during the past year, -

48 Total amount expended for agencies and other expenses,

49 Total cost of road and equipment,

50 Amount of assets or property held by the corporation in addition to the cost of the road, [after deducting dividend payable Jan. 1, 1862, of $\$ 124,671$, monthly balances due other roads, \&c., of $\$ 57,98813$, and floating debt of $\$ 86,655$ 58] -

\section{Characteristics of Road.}

51 Length of road,

52 Length of single main track, - . -

53 Length of double main track, - - -

54 Length of branches owned by the company, stating whether they have a single or double track,

55 Aggregate length of sidings, and other tracks, excepting main tracks and branches,

56 Weight of rail, per yard, in main road,

57 Weight of rail, per yard, in branch roads, (specify the different weights per yard.) - -

58 Maximum grade, with its length, in main road, -

59 Maximum grade, with its length, in branch roads,

60 Total rise and fall in main road,

61 Total rise and fall in branch roads, -

62 Shortest radius of curvature, with length of curve, in main road,

63 Shortest radius of curvature, with length of curve, in branch roads,

64 Total degrees of curvature in main road,
815,51229

32,68579

198,51800

848,19808

1,30000

199,81800

80,31800

3,90300

145,89700

76,41500

Nothing.

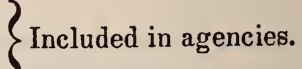

145,89700

272,38894

Nothing.

272,388 94

$4,303,49964$

$\$ 396,05398$

74 26-100th miles.

46 47-100th miles.

2779 100th miles.

$14-100$ mile double; in all, 8 79-100th miles.

21 9-10th miles.

? Nearly 3 miles, 48 lbs..

\} balance 56 to 60 .

$48,56,58$ and $60 \mathrm{lbs}$.

\} $47 \frac{1}{2}$ feet per mile, for 77 -

100 th miles.

$36 \mathrm{ft}$. for 140 -100th miles.

1498 feet.

146 feet.

1050 feet radius; length

1150 feet.

1000 feet radius; length

- 1150 feet.

$1988^{\circ}$. 
65 Total degrees of curvature in branch roads,

66 Total length of straight line in main road,

67 Total length of straight line in branches,

68 Aggregate length of wooden truss bridges,

69 A ggregate length of all other wooden bridges, -

70 Aggregate length of iron bridges,

71 Whole length of road unfenced on both sides, [except that otherwise guarded,]

72 Number of public ways crossed at grade,

73 Number of railroads crossed at grade, -

74 Remarks,

75 Way stations for express trains,

76 Way stations for accommodation trains,

77 Flag stations, - $\quad$ - $\quad$ -

78 Whole number of way stations,

79 Whole number of flag stations,

Doings dURing the Year.

80 Miles run by passenger trains, -

81 Miles run by freight trains,

82 Miles run by other trains, -

83 Total miles run, - -

84 Number of passengers carried in the cars,

85 Number of passengers carried one mile,

86 Number of tons of merchandise carried in the cars

87 Number of tons of merchandise carried one mile,

88 Number of passengers carried one mile, to and from other roads,

89 Number of tons carried one mile, to and from other roads,

90 Rate of speed adopted for express passenger trains, including stops,

91 Average rate of speed actually attained by express passenger trains, including stops and detentions,

92 Rate of speed adopted for accommodation trains,

93 Rate of speed actually attained by accommodation trains, including stops and detentions,

94 Average rate of speed actually attained by special trains, including stops and detentions,

95 Average rate of speed adopted for freight trains, including stops,

96 Estimated weight in tons of passenger cars (not including passengers) hauled one mile,

97 Estimated weight in tons of merchandise cars (not including freight) hauled one mile,

Expendityres for Working the Road.

98 For repairs of road, maintenance of way, exclusive of wooden bridges, and renewals of iron,

99 For repairs of wooden bridges,

100 For wages of switchmen, average per month,

101 For wages of gate-keepers, average

102 For wagcs of signal-men, average per month,

$\left.\begin{array}{ll}20 & 00\end{array}\right\}$

103 For wages of watchmen, av. per mo. 3154 )
$4563^{3}$.

49 73-100th miles.

5 81-100th miles.

2612 feet.

7007 f $\in$ et.

None.

$1 \frac{3}{8}$ miles.

96

1 horse and 5 steam.

None.

None.

20

7

20

7

427,225

171,468

24,673

$1,708,254$

25,613,256

207,680

$5,871,649$

7,697,238

$2,034,080$

35 miles per hour.

34 miles per hour.

'24 miles per hour.

23 miles per hour.

20 miles per hour.

12 miles per hour.

$8,894,400$

$11,077,054$

69,92128

10,37738

22,566 95
623,366 
104 Number of men employed, exclusive of those engaged in construction,

105 For removing ice and snow, -

106 For repairs of fences, gates, houses for signalmen, gate-keepers, switchmen, tool-houses, -

107 Total for maintenance of way,

\section{Motive Power and Cars.}

Horse power,

108 For repairs of locomotives,

109 For new locomotives, to cover depreciation,

110 For repairs of passenger cars,

111 For new passenger cars, to cover depreciation,

112 For repairs of merchandise cars,

113 For new merchandise cars, to cover depreciation,

114 For repairs of gravel and other cars,

115 Total for maintenance of motive power and cars,

116 Number of engines

117 Number of passenger cars, -

118 Number of baggage cars,

119 Number of merchandise cars,

120 Number of gravel cars,

\section{Miscellaneous.}

121 For fuel used by engines during the year, viz.: 1. Wood, number of cords, 9882. Cost of the same,

2. Coal, number of tons, (reckoning $2240 \mathrm{lbs}$. to the ton,) 4261. Cost of the same,

122 For oil used by cars and engines,

123 For waste and other material for cleaning,

124 For salaries, wages and incidental expenses, chargeable to passenger department,

125 For salaries, wages and incidental expenses, chargeable to freight department,

126 For gratuities and damages,

127 For taxes and insurance,

128 For ferries,

129 For repairs of station buildings, aqueducts, fixtures, furniture,

130 For renewals of iron, [as below, 17,134 33]

131 For new iron laid down, deducting the value of old iron taken up,

132 For amount paid other companies, in tolls for passengers and freight carried on their roads, specifying each company,

133 For amount paid other companies, as rent for use of their roads, specifying each company,

134 For salaries of president, treasurer, superintendent, law expenses, office expenses of the above offices, and all other expenses not included in any of the foregoing items,

135 Total miscellaneous, -

136 Total expenditures for working the road,

137 Total amount of interest paid during the year,
573

3,64892

3,33174

109,84627

9,20000

32,84032

Nothing.

14,06526

Nothing.

7,09381

Nothing.

4280

63,24219

36

54

14

543 and 22 hand cars.

20

\section{7,203 75}

25,34501

7,46574

2,00139

68,18481

54,65240

1,56150

16,80403

Nothing.

26,83730

17,13433

Nothing.

7,500 00 Danvers R.

13,21588

287,90614

460,99460

Received more than paid. 
138 For passengers :-

INCOME dURing the Year.

1. On main road, including branches owned by company, - - 364,243 17

2. To and from other roads, specifying what, viz.: Great Falls and Conway ; Cochecho; Portsmouth and Concord ; Salem and Lowell; Contoncook River; Boston, Concord and Montreal; Concord, Manchester and Lawrence; Manchester and North Weare; Stoneham Street ; Vermont Central ; Northern; Connecticut and Passumpsic Rivers; Concord and Claremont; South Reading Branch; Port., Saco and Ports. 112,176 87

139 For freight:-

1. On main road and branches owned by company,

2. To and from other connecting roads, - $\quad$ - $\quad$ - 67,55199

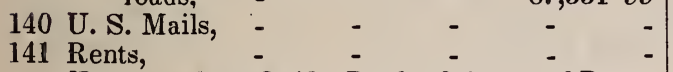

[Interest, $\$ 5,24248$; Portland, Saco and Portsmouth Railroad surplus, $\$ 4,000$, - -

142 Total income, - - - - -

143 Net earnings, after deducting expenses, -

\section{Dividends.}

$1446 \frac{1}{2}$ per cent. Total, -

145 Surplus not divided, [earned this year,]

146 Surplus last year,

147 Total surplus, -

Estimated Depreciation beyond the ReNEWALS, VIZ.:

148 Of road and bridges,

149 Buildings,

150 Engines and cars, $\quad[\$ 6,103$, and this amount is charged off,]

[Net, after deducting expenses and deprec'n, ] -

\section{Mortgage Debts.}

151 Amount of debts secured by mortgage of road and franchise, or any property of the corporation, per last report, -

152 Mortgage debt paid since last report, -

153 Increase of mortgage debt since last report, -

154 Present amount of mortgage debts,

155 Number of mortgages on road and franchise, or any property of the corporation,
476,42004

267,28684

$10,168 \quad 74$

12,94694

9,24248

776,06504

315,07044

270,12050

38,84694

583,73216

622,57910

Nothing.

"6

610300

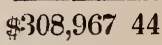

Nothing.

66

66

66

Not any. 
- All which is respectfully submitted,

FRANCIS COGSWELL,

JAMES H. DUNCAN,

G. W. KIT'TREDGE,

PETER T. HOMER,

DANIEL M. CHRISTIE,

I. M. SPELMAN,

HENRY SALTONSTALL,

Directors of the Boston and Maine Railroad.

Suffolk, ss. December $27,1861$.

Then personally appeared Francis Cogswell, James H. Duncan, G. W. Kittredge, Peter T. Homer, Daniel M. Christie, I. M. Spelman, and Henry Saltonstall, and severally made oath to the truth of the foregoing.

Before me,

Horace B. Wilbur, Justice of the Peace.

NotE.-Included in the foregoing are the earnings and expenses attending the operation of the Danvers Railroad and the Newburyport Railroad, which have been, by authority of law, leased to this corporation. The rent for the use of the Newburyport Railrnad has been prepaid for one hundred years by a loan to it for that term of time, not on interest.

\section{S TATE M N T}

Of Fatal Accidents and Serious Injuries, from Nov. 30, 1860, to Nov. 30,1861 .

December 2, 1860.-J. P. Currier was found lying by the side of the track dead, about two miles west of Newton Station, N. H. Supposed to have been struck by the night train.

December 26, 1860.-James Riley, in crossing the track in Georgetown, Mass., was struck by the train and had one of his legs broken.

January 14, 1861.-J. F. F. Bailey, while crossing the track at East Kingston, N. H., was struck by the train and instantly killed.

January 21, 1861.-John Gooch, in the employ of this Road, while attempting to help a man on a freight train in motion at Andover, Mass., fell under it and was instantly killed. 
January 29, 1861.-J. Doyle, while attempting to get on a train in motion, at South Reading, fell, and had one of his legs cut off by the wheels of the train, but was not fatally injured.

April 25, 1861.-Charles Cross, employed by this Road, while shackling cars at Newburyport, Mass., was crushed between them and instantly killed.

June 22, 1861.-Abby Jackson, thought to be insane, fell from the cars, near South Reading Depot, and was instantly killed.

October 22, 1861.-John Jaseph, in the employ of this Road, fell from a train in motion, and had his arm cut off by the cars, but was not otherwise injured.

October 28, 1861.-William E. Morse, nine years old, while attempting to get on a passing train at Haverhill, fell, and had both his legs run over, but was not fatally injured.

November 4, 1861.-Edward Keating, ten years of age, while attempting to get on a train in motion, at Ballard Vale, fell, and was so injured that he died next day.

November 18.-Luke Hutchinson, an employé, fell from a freight train, in Plaistow, N. H., and was instantly killed.

In neither of these accidents does any blame attach to the Company.

The undersigned have examined the foregoing Report of the Directors of the Boston and Maine Railroad, and approve the same.

WILLIAM STEVENS,

Commissioner for Massachusetts.

W. H. ESTEY,

Commissioner for New Hampshire. 

OF THE

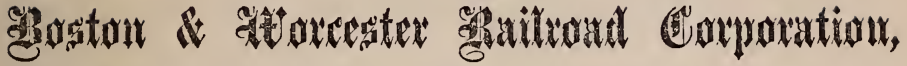

\section{Being for the Year ending November 30, 1861.}

To be returned to the Secretary of the Commonwealth, together with 1000 printed copies of the same, on or before the first Wednesday in January next.

General Statutes, Chap. 63, Sections 132 to 135.

Capital Stock,

Number of shares of capital stock issued, Increase of capital, since last Report, Capital paid in, per last Report, - Capital paid in, since last Report,

Total amount of capital stock paid in, Funded debt, per last Report,

Funded debt, paid since last Report, -

Funded debt, increase of, since last Report,

Total present amount of funded debt,

Floating debt, per last Report,

Floating debt, paid since last Report, -

Floating debt, increase of, since last Report,

Total present amount of floating debt,

Total present amount of funded and floating debt,*

Average rate of interest per annum, paid during the year,

Maximum amount of debts during the year,

\section{Cost of Road and Equipuent.}

For graduation and masonry, per last Report,

For graduation and masonry, paid during the past year,

Total amount expended for graduation and masonry,

Reduction of construction account, to conform to vote of stockholders,

For wooden bridges, per last Report, -

For wooden bridges, paid during the past yr.

Total am't expended for wooden bridges

\begin{tabular}{|c|c|}
\hline & $\begin{array}{r}4,500,000 \\
45,000\end{array}$ \\
\hline none & $4,500,000$ \\
\hline $\begin{array}{l}\text { none } \\
\text { none } \\
\text { none } \\
\text { none } \\
\text { none } \\
47,584 \quad 47\end{array}$ & $4,500,000$ \\
\hline 78,51955 & 126,10402 \\
\hline & 126,10402 \\
\hline 6 per cent. & 160,65311 \\
\hline 737,37651 & \\
\hline none & \\
\hline 737,37651 & \\
\hline $\begin{array}{l}77,37651 \\
266,10267 \\
\text { none } \\
266,10267\end{array}$ & 660,00000 \\
\hline
\end{tabular}

* Floating debt consists of - Note payable, . . . . $\$ 9,00000$

Balances to other roads, \&c. 111,68602

Unclaimed divịdends, . . , $\mathbf{6 , 4 1 8 0 0}$ 
Reduction of construction account, to conform to vote of stockholders, -

Total amount expended for iron bridges

( 2 built in 1860, charged to repairs.)

For superstructure, including iron, per last

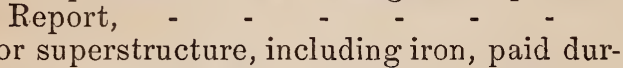
ing the last year,

Total amount expended for superstruc-

ture, including iron, - - -

Reduction of construction account, to conform to vote of stockholders, -

For stations, buildings and fixtures, per last Report,

For stations, buildings and fixtures, paid during the past year,

Total am't expended for stations, buildings and fixtures,

Reduction of construction account, to conform to vote of stockholders, -

For land, land-damages, and fences, per last Report,

For land, land damages and fences, paid during the past year, - - 4,930 20

Total amount expended for land, landdamages and fences,

Reduction of construction account, to conform to vote of stockholders, - -

For locomotives, per last Report, - -

For locomotives, paid during the past year, one-charged in expenses,

Total amount expended for locomotives,

For passenger and baggage cars, per last Report,

For passenger and baggage cars, paid during the past year,

Total amount expended for passenger and baggage cars,

For merchandise cars, per last Report,

For merchandise cars, paid during the past year,

Total amount expended for merch. cars, For engineering, per last Report, -

For engineering, paid during the past year,

Total amount expended for engineering,

Reduction of construction account, to conform to vote of stockholders,

For agencies and other expenses, per last Report,

$26,10267210,00000$

$1,410,81106$

none

$1,410,81106$

$85,81106 \quad 1,325,00000$

760,25488

none

760,25488

$15,25488 \quad 745,00000$

897,72102

897,72102

$24,72102 \quad 873,00000$ 179,42523

179,42523

75,56576

none

182,42533

75,56576

none

228,75921

182,42533

none

228,75921

$9,17556 \quad 219,58368$

none 
For agencies and other expenses, paid during the past year,

Total amount expended for agencies and other expenses, - - -

Cost of road and equipment reluced by vote of stockholders to "

Amount of assets or property held by the corporation, in addition to the cost of the road,

\section{Characteristics of Road.}

\section{Length of road,}

Length of single main track, - Length of double main track, - -

Length of branches owned by the Company, stating whether they have a single or double track,

Aggregate length of sidings \& other tracks, excepting main tracks and branches,

Wreight of rail, per yard, in main road,

$\mathrm{W}^{\top}$ eight of rail, per yard, in branch roads (specify the different weights per yard),

Maximum grade, with its length, in main road,

Maximum grade, with its length, in branch roads,

Total rise and fall in main road, - -

Total rise and fall in branch roads,

Shortest radius of curvature, with length of curve, in main road,

Shortest radius of curvature, with length of curve, in branch roads,

Total degrees of curvature, in main road,

Total degrees of curvature, in branch roads,

Total length of straight line, in main road,

Total length of straight line, in branches, Agrregate length of wooden truss bridges, Aggregate length of all other wooden loridges,

Aggregate length of iron bridges,

Whole length of road unfenced on both sides,

Number of public ways crossed at grade,

Number of railroads crossed at grade,

Remarks,

Way stations, for express trains, -

Way stations, for accommodation trains, none

none

$4,500,00000$

743,17974

$44 \frac{5}{8}$ miles.

none

$44 \frac{5}{8}$ miles.

24 miles, single.

$15 \frac{1}{2}$ miles.

$56,60,63,66$ lbs.

$39,50 \mathrm{lbs}$.

$\left\{30 \mathrm{ft}\right.$. for $10 \frac{1}{4} \mathrm{~m}$. \& $37 \frac{1}{2}$ $\mathrm{ft}$. for $1100 \mathrm{ft}$.

$\left\{30 \mathrm{ft}\right.$. for $2 \frac{1}{2} \mathrm{~m}$. and 37 ft. for $1 \frac{3}{4}$ miles.

714 feet.

316 “

600 feet for 900 feet.

$500 \mathrm{ft}$. for 1080 feet.

1855 degrees.

1228

$26 \frac{2}{10}$ miles.

$15 \frac{7}{8}$

250 feet.

$\{1628 \mathrm{ft}$. on main road, $\{1490 \mathrm{ft}$. on branches.

125 feet.

10 miles.

44 on m. road-26 on brs.

$\{2-B$. \& P. and

$\{$ W. \& N.

1-Framingham.

14 on main -16 on brs.

16 
Whole number of Way stations, including Branches, - - - - - 30

Whole number of flag stations, - -

16

DoINGS DURING THE Year.

Miles run by passenger trains, - -

Miles run by freight trains, - - -

Miles run by other trains, - - -

Total miles run, - - - -

Number of passengers carried in the cars,

Number of passengers carried one mile,

Number of tons merch'dise carried in cars,

Number of tons of merchandise carried $1 \mathrm{~m}$.

Number of passengers carried one mile, to and from other roads,

Number of tons carried one mile, to and from other roads, - - - - -

Rate of speed adopted for express passenger trains, including stops,

Average rate of speed actually attained by express passenger trains, including stops and detentions,

Rate of speed adopted for accom. trains,

Rate of speed actually attained by accom. trains, including stops and detentions,

Average rate of speed actually attained by special trains, incl. stops and detentions,

Average rate of speed adopted for freight trains, including stops and detentions,

Estimated weight in tons of passenger cars (not including passengers), hauled 1 mile,

Estimated weight in tons of merchandise cars (not including freight), hauled $1 \mathrm{~m}$.

Expenditures for Working the Road.

For repairs of road, maintenance of way exclusive of wooden bridges, and renewals of iron,

For repairs of wooden bridges, - -

For wages of switchmen, average per month,

For wages of gate-keepers, average per month,

For wages of signal-men, average per month,

For wages of watchmen, average per month,

$1,476,394$

528,951

$23,239,178$

345,174

$13,403,609$

$7,659,848$

$10,803,008$

33 miles per hour.

$\begin{array}{llll}33 & \text { “ } & \text { “ } & \text { “ } \\ 25 & \text { “ } & \text { “ } & \text { “ } \\ 25 & \text { “ } & \text { “ } & \\ 11 & \text { “ } & \text { “ }\end{array}$

$14,856,780$

$19,443,326$

51,23911

8,09844

$\$$

$\$ 2308$

13,81980

$\$ 4082$ 
Number of men employed, exclusive of those engaged in construction,

For removing ice and snow (this item to include all labor, tools, repairs, and extra steam power used), -

For repairs of fences, gates, houses for signal-men, gate-keepers, switchmen, toolhouses,

Total for maintenance of way, - -

509

Included in road and engine repairs.

Included in road and building repairs.

73,15735

\section{Motive Power and Cars.}

For repairs of locomotives,

For new locomotives, to cover depreciation, For depreciation of locomotives, - For repairs of passenger cars, - For depreciation, - - - - For repairs of merchandise cars, - For depreciation, For repairs of gravel and other cars, Total for maintenance of motive power and cars, - - - - Number of engines, - $\quad-\quad-$

Number of passenger cars, -

Number of baggage cars, -

Number of merchandise cars, -

Number of gravel cars, - -

\section{Miscellaneous.}

For fuel used by engines during the year, - viz.-Wood, number of cords, $\quad 5,133$ Coal, number of tons (reck'g $2,240 \mathrm{lbs}$. to the ton),

For oil, used by cars and engines, For waste and other material for cleaning, For salaries, wages and incidental expenses, chargeable to passenger department, For salaries, wages and incidental expenses, chargeable to freight department, For gratuities and damages, - For taxes and insurance, - - For ferries,
30

31,20374

4,70000

8,97126

17,79675

3,77828

11,71233

9,12126

88459

$\left\{498\right.$ wh., 14 wh., $\frac{3}{5}$ of 2

$\left\{16 \mathrm{wh} ., \frac{44}{236}\right.$ of $188 \mathrm{wh}$. N. Y. Line.

$\left\{9\right.$-also $\frac{44}{236}$ of $7 \mathrm{~N}$. Y. Line.

275 8wh., 13 4wh. equal to $5634 \mathrm{wh}$.

$554 \mathrm{wh}$.

58,57324

6,71291

1,17279

68,45553

101,61071

1,57233

12,01370

none 
For repairs of station buildings, aqueducts, fixtures, furniture, - $\quad$ - - -

For depreciation, - - - - -

For renewals of iron, including laying down,

For new iron laid down, deducting the value of old iron taken up,

For amount paid other companies, in tolls for passengers and freight carried on their roads, specifying each company,

For amount paid other companies, as rent for use of their roads, specifying each company. (Agricultural Branch) -

For salaries of president, treasurer, superintendent, law expenses, office expenses of the above offices, and all other expenses not included in any of the foregoing items,

Total amount paid during the year in reducing curvature at Brighton, charged exp.

To Western Railroad-subsidy, - -

Total miscellaneous, - - -

Total expenditures for working the road,

Total am't of int. paid during yr. \$540

13,19869

10,00000

$\{31,14685$

none

11,89510

27,38730

3,27369

12,00000

$359,012 \cdot 84$

520,33840

INCOME DURING THE YEAr.

For Passengers :-

1. On main road, including branches owned by company,

2. To and from other roads, specifying what - (Western, Norwich, Nashua, Charles River), -

For Freight:-

1. On main road and branches owned by company,

2. To and from other connecting roads,

U. S. Mails, -

Rents,

Balance of interest, - $\quad-\quad-$

Total income, - - - - .

Net earnings, after deducting expenses,

\section{Divinends.}

8 per cent. Total, - - - -

Surplus not divided, - . . .

Surplus last year, - _ $\quad$ - 599,98243

Reduced by credit to constr'n, 243,37190

304,19598

$168,53343 \quad 472,72941$

168,72975

$245,954 \quad 23 \quad 414,68398$

16,83812

15,59770

9,08358

928,93279

408,59439

360,00000

48,59439

356,61053

405,20492 


\section{Estimated Depreciation beyond the RENEWALS, viz. :}

\section{Roads and bridges,}

Building, Engines and cars,

\section{Mortgage Debts.}

Amount of debts, secured by mortgage of road and franchise, or any property of the Corporation, per last Report, Mortgage debt, paid since last Report, Mortgage debt, increase of, since last Rep't, Total present amount of mortgage debt, Number of mortgages on road and franchise, or any property of the Corporation, none

none

none

none

none

none

nune

none

\section{ACCIDENTS DURING THE YEAR.}

Feb. 9th. William Burns, brakeman on a freight train, jumped or fell from the engine, was run over by the train and instantly killed.

June 18: $h$. The body of a man (n:me unknown) was found on the track in Needham-supposed to have been run over by a passing train.

June 22d. Mary Ann Whalon, a child 5 years old, was playing under freight ears, unobservend; the train was moved, and she was instantly killed.

July 8th. George Barrett, passen rer-train brakeman, while the train was being switched at Worcester, fell, was run over and fatally injured.

July 20th. Lawrence Doyle, while walking on the track west of the Proridence Crossing in Boston, was knocked down by a passing train and had an arm broken.

July 27th. Michael Curren, a child two years old, while plaving on the track of the Milford Branch, near Holliston, was run over and instantly killed.

A $\iota \mathrm{g} .23 \mathrm{~d}$. Mary Burke jumped from the platform of a car at Cambridge Crossing, on the wrong side of the train (against the remonstrance of the flagman), fell upon the opposite track directly in front of a passing train, was run over and instantly killed.

Oct. 21st. 'Thomas Carley went under the cars as the train was about to move, to recover his dog. 'The train in starting fractured one of his legs and slig'ttly injured the other.

Oct. 26th. James Brown, while walking on the track near the Providence Crossing, in Boston, was hit by a passing train and seriously injured.

(Signed)
Benj. F. White, Peter T. Homer, ISAAC EMERY, D. Waldo Lincoln,

Direclors B.\&W.R.R.

Commonwealth of Massachusetts, Suffolk ss. Dec. 30, 1861. Then personally appeared the above named Ginery Twichell, Daniel Denny, Emory Washburn, Benj. F. White, Peter T. Homer, Isaac Emery, D. Waldo Lincoln, and severally made oath to the truth of the foregoing statement by them subscribed; and at the same time person:lly appeared the above named Nathaniel Hammond, and affirmed that said statement was true according to his best knowledge and belief. 



\section{R E P O R T}

OF THE

\section{I R E C T O R}

OF THE

\section{BROADWAY HORSE RAILROAD}

\section{COMPA N Y}

FOR THE YEAR ENDING NOVEMBER 30, 1861.

B O T T N :

WRIGHT \& POTTER, PRINTERS, 4 SPRING LANE.

1861 . 
14. 


\section{REPORT OF THE DIRECTORS}

OF THE

\section{BROADWAY HORSE RAILROAD COMPANY.}

For the year ending November 30, 1861. General Statutes, Chap. 63, Sects. 143, 144

\section{Condition of the Company.}

1. Capital Stock, fixed by Charter, .

2. Capital Stock, as voted by the Company, .

3. Capital Stock paid in, in cash,

4. Capital Stock paid in, in work and materials, by contractors and others, .

5. Funded debt,

6. Floating debt,

7. Total debt,

8. Amount of above debt secured by mortgage of the road and franchise, or any property belonging to the corporation, or standing in its name,

9. Number of mortgages on road and franchise, or any property of the corporation, specifying the number and amount of mortgages on road and franchise, and each kind of property,

10. Amount of assets on hand, exclusive of the road and equipment, and exclusive of all property on hand, used, or which is to be used, in running the road and keeping it in repair, .

$-$

$\overline{-}$

$\overline{-}$

?

$-$

21044

\section{Cost of the ROAd.}

11. Amount expended for labor in excavating for the track, laying foundation and rails,

12. Amount expended for timber for foundation,

13. Amount expended for iron and other metal for rails, chairs, spikes, or other articles, used in building the road,

14. Amount expended for paving,

15. Amount expended for paving stones, . .

16. Amount expended for engineering, $\dot{\text {. }}$.

17. Amount expended for interest, salaries of officers during construction of road, and other expenses not included in any of the above items, which have been included, on the books of the company, in the cost of the road, not including items of equipment or running expenses, as mentioned below,

18.

Total cost of road, : $\quad: \quad: \quad . \quad$.

19. Amount included in the present and in past years, among the running expenses for estimated or actual depreciation of the road,

20. Net cost of road,

\section{$\$ 59,33288$}

8




\section{Cost of Equipment.}

21. Number of cars and cost, .

22. Number of horses and cost,

23. Cost of omnibuses, sleighs and other vehicles, excepting cars, owned by the Company,

24. Cost of land and buildings thereon when purchased,

25. Cost of buildings used for offices, stables, \&c., erected by the Company, or standing on land not owned by the Company,

26. Cost of other articles of equipment, (specifying what,)

27. Total cost of equipment, $\quad . \quad \vdots$

28. Amount included in the present and in past years in the running expenses for estimated or actual depreciation of any of the above items,

29. Net amount at which the equipment stands charged on the books of the Company, .

\section{Characteristics of the Road.}

30. Length of single main track,

31. Length of double main track,

32.

Total length of road,

Road leased. Equipment

furnished by lessees.

$7,601.50$ feet.

$7,302.50$ feet.

14,904 feet.

33. Length of branches owned by the Company, stating whether they have a single or double track,

34. Aggregate length of switches, sidings, turnouts, and other track, excepting main track and branches,

35. Total length of rail, .

36. Weight of rail used, per yard, (specifying whether of cast or rolled iron, ) .

37. Maximum grade, per mile, on road, with length of grade,

38. Shortest radius of curvature, with length of curve,

39. Greatest length of single track on road between two turnouts,

40. Total length of main track which is paved,

\section{Doings during the Year.}

41. Total number of miles run during the year,

42. Number of passengers carried in the cars,

43. Rate of speed adopted, including stops and detentions,

44. Rate of speed actually attained, including stops and detentions, .

45. Number of persons employed, regularly, (specifying the occupations of each, ) .

46. 'Total number of trips run during the year,

47. Average number of passengers each trip, .

\section{Expenditures for Working the Road.}

48. For repairs of road, including repairs of foundation, renewals of iron, and renewals of pavement,

49. For general repairs, including repairs of cars, omnibuses and harnesses, and for shoeing horses,

467 feet.

45,347 feet.

55 lbs.

335 feet, and 400 feet. 45 feet.

1,603 feet.

All paved. 
50. For repairs of real estate, including repairs of buildings used as stables, offices, or for any other purposes, by the Company,

51. For wages, including the wages of every person regularly employed, excepting the president, directors, superintendent, and treasurer, .

52. For interest,

53. For taxes and insurance, : $\quad \cdot \quad \cdot \quad \cdot$

54. For tolls paid other companies for the right to pass over their roads,

55. For rent paid other companies for use of their roads,

56. For provender, - to include cost of hay, grain, straw, or other articles used for the food and bedding of horses,

57. For miscellaneous articles purchased during the year - such as harnesses, blankets, \&c., the use of which continues for one or more years - and not included in the cost of equipment, .

58. For loss on horses - that is to say, the difference between the present estimated value of the horses 8 wned by the Company subtracted from the estimated value of those on hand at the commencement of the year, added to the cost of those purchased during the year; or if this is the first report of the Company, then the difference between the estimated value of the horses on hand and their cost-giving the present average estimated value of each horse,

59. For incidental expenses, - to include printing, president's, directors', treasurer's, and superintendent's salaries, and all expenses other than those belonging to the actual working of the road,

60. For all other expenses,

61. For amount charged on the Company's books during the year, for estimated or actual depreciation of the following property :-

$\begin{array}{lll}\text { Cars, : } & \text { : } & : \\ \text { Horses, } & : & : \\ \text { Omnibuses, : } & : & : \\ \text { Real estate, : } & : & : \\ \text { Road, } \\ \text { Other property, } & : & : \\ \text { Total, } & \text { : } & \text { : }\end{array}$

62. Total expenses, : $\quad \cdot \quad \cdot \quad$ :

No return from lessees.

\section{EARNings.}

63. Received from passengers in cars and omnibuses, and for tickets sold,

64. From other roads, as toll or rent for use of road,

65. From United States mails,

66. For sales of manure,

67. From other sources,

68. Total earnings,

69. Net earnings, after deducting expenses,

70. Surplus earnings of previous year, on hand,

71. Net earnings, as above,

72. Total surplus for payment of dividends, .

No return from lessees. 
73. Dividends declared, during the year,

74. Total percentage of dividends, for the year,

75. Present surplus,

\section{Miscellaneous.}

76. Increase during the year-

Of capital stock, as fixed by the charter, Of capital stock, as voted by the Company, Of capital stock, paid in,

77. Increase of funded debt, during the year,

78. Increase of floating debt, during the year,

79. Decrease of funded debt, during the year,

80. Decrease of floating debt, during the year,

81. Increase of mortgage debt, during the year,

82. Decrease of mortgage debt, during the year,

83. Increase in cost of road, during the year, including amount charged for depreciation thereon,

84. Decrease in nominal cost of road, by amount charged for depreciation thereon,

85. Increase in cost of equipment, during the year, including amount charged for depreciation thereon, .

86. Decrease in cost of equipment, by sale of any portion thereof, or by amount charged for depreciation,

87. List of accidents on road during the year,
Two.

1220-100

$\$ 1091$

$\$ 5,60000$

$-$

$-$

$-$

$-$

$-$

5,54143

$-$

-

SETH ADAMS,

HENRY SOUTHER,

D. L. BRADFORD,

S. G. HOWE,

GEO. H. EVERSON,

Directors of the Broadroay Horse Railroad Co. 




\title{
R E T U R N S
}

\author{
OF THE
}

\section{CAMBRIDGE RAILROAD COMPANY}

\author{
AND THE

\section{UNION RAILWAY COMPANY,}

TO THE

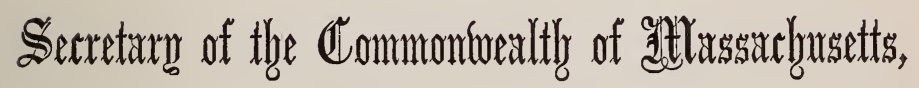

FOR THE YEAR ENDING NOVEMBER 30, 1861.

$C A M B R I D G E$ :

WEL CH, B I GELOW, AND COMPANY, PRINTERS TO THE UNIVERSITY.

1861 . 


\title{
CAMBRIDGE RAILROAD COMPANY.
}

\author{
THE SIXTH RETURN OF THE CAMBRIDGE RAILROAD COMPANY
} TO THE SECRETARY OF THE COMMONWEALTH OF MASSA-

CHUSETTS, -FOR THE YEAR ENDING NOVEMBER 30, 1861, UNDER ACTS OF 1857, CHAPTERS 40 AND 240.

\section{Condition of the Company.}

Capital Stock, fixed by charter, . . . . . . . . . . $\$ 600.000$ Capital Stock, as roted by the Company, . . . . . . . 444,800

Capital Stock paid in, Total, (1) •,$\quad \cdot \quad \cdot$

(See Remarks preceding the Return of this Company for the year 1857.)

Funded debt,

Floating debt,

Total debt,

Amount of above debt secured by mortgage of the road and franchise, or any property belonging to the corporation, or standing in its name,

$$
\begin{aligned}
& \text {. . . } \$ 150,000 \\
& \text { None. } \\
& \text {. } \$ 150,000 \\
& \cdot \cdot
\end{aligned}
$$

$$
\frac{444,800}{\$ 444,800}
$$

ing the 


\section{Cost of the Road.}

This road was built by contract, for the sum of .

The expenditures, for additional work beyond that specified in the contracts, have been as follow:-

For alterations of road, lengthening switches and turnouts, \&c., \&c.,

For lumber, .

For iron work required for alterations, $\dot{\&} c_{,} \dot{\&}$

For paving,

For paving-stones and gravel,

For engineering,

For interest, salaries of officers during construction of road, and other expenses not included in any of the above items, which have been included on the books of the Company in the cost of the road, not including items of equipment or running expenses,

Total cost of the road,

Amount included, in the present and in past years, among the running expenses for estimated or actual depreciation of the road,

Net cost of road,

\section{Characteristics of the Road.}

Length of single main track,

Length of double main track,

Total length of road

Length of branches owned by the Company, stating whether they have a single or double track.

Aggregate length of switches, sidings, turn-outs, and other track, excepting main track and branches,

Total length of rail

Weight of rail used, per yard, specifying whether of cast or rolled iron.

Maximum grade, per mile, on road, with length of grade,

Shortest radius of curvature, with length of curve,

Greatest length of single track on road between two turnouts.

Total length of main track which is paved, .

27,500 feet.

22,828 feet.

50,328 feet.

$\{31,511$ feet. - All single

$\{$ track.

4,646 feet.

86,485 feet.

The total length of rail on this road is equal to that of a single track road 20 3713-5280 miles long.

Rolled Iron. - Grooved rail, 64 and 62 lbs. per yard. - T rail 33 lbs. per yard.

209 11-21 feet per mile; 630 feet in length, in Cambridge St., Boston. 40 feet; 17 feet in length.

3,290 feet, in River Street Branch.

All the main track is paved. 


\section{Miscellaneous.}

Increase during the year, -

Of capital stock as fixed by charter,

Of capital stock as voted by the company, .

Of capital stock paid in,

Increase of funded debt, during the year,

Increase of floating debt, during the year,

Nothing.

Nothing.

Decrease of funded debt, during the year, . . . . . Nothing
Decrease of floating debt, during the year, .

Decrease of funded debt, during the year, . . . . N Nothing.
Decrease of floating debt, during the year, .

$\$ 24,600$

300,000

144,800

144,800

Increase of mortgage debt, during the year, . . Nothing.

Decrease of mortgage debt during the year, . . . Nothing.

Increase in cost of the road, during the year, including amount charged for depreciation thereon,

Decrease in nominal cost of road, by amount charged for depreciation thereon,

The entire road owned by this company is under lease to the Union Railway Company, who pay as rent therefor nine per cent per annum on the capital stock of this Company, the interest on its debt, and two per cent per annum on the mortgage debt, as a sinking fund for its payment. The road being equipped, operated, and kept in repair by the Union Railway Company, reference is made to its return for replies to the interrogatories, in the blank form of return furnished by the Secretary of the Commonwealth, under the heads of Cost of Equipment, Doings during the Year, Earnings, Expenditures for Working the Road, and List of Accidents.

A statement of the present condition of the Sinking Fund, for the Redemption of the Company's Mortgage Bonds, is appended to the Return.

Respectfully submitted, by

$\left.\begin{array}{l}\text { CHARLES C. LITTLE, } \\ \text { R. E. DEMMON, } \\ \text { ESTES HOWE, } \\ \text { W. A. SAUNDERS, }\end{array}\right\} \begin{gathered}\text { Directors of the } \\ \text { Cambridge liailroad } \\ \text { Company. }\end{gathered}$

(Co m montwe altb of $\mathfrak{A}$ assacbuset $t$ s.

Middlesex ss.

Cambridge, December 27, 1861.

Then personally appeared the above-named Charles C. Little, R. E. Demmon, Estes Howe, and W. A. Saunders, and made oath that the foregoing Return, by them signed, is true to the best of their knowledge and belief.

Before me,

JOSEPH H. CONVERSE, Justice of the Peare.

* The capital stock was increased by an Act of the Legislature, entitled "An Act concerning the Waltham and Watertown Railroad Corporation," approved March 21, 1861. 


\section{STATEMENT OF THE CONDITION OF THE SINKING FUND FOR THE REDEMPTION OF THE MORTGAGE BONDS OF THE CAM- BRIDGE RAILROAD COMPANY.}

In pursuance of the 24th Chapter of the Laws of Massachusetts, 1855, the Trustees of the Sinking Fund for redemption of the Bonds (to the amount of one hundred and fifty thousand dollars) issued by the Cambridge Railroad Company, have received $\$ 19,956.10$, and have advanced to said Fund $\$ 136.90$, all of which has been invested in forty-seven of said Bonds, of the amount of twenty-three thousand and five hundred dollars, said railroad being mortgaged to said trustees as security for said Bonds, and payments of interest thereon.

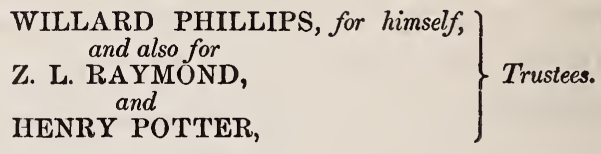

Boston, December 27, 1861.

\section{Trustees' Receipts.}

As per statement appended to the Return of the Cambridge Railroad Company, Nov. 30, 1860, . .

April 1, 1860. From the Cambridge Railroad Company, 1 per cent on amount of Bonds issued, . . . . . $1,500.00$

Oct. 1, 1861. From the Cambridge Railroad Company, 1 per cent on amount of Bonds issued, $\quad . \quad$. $\quad . \quad$. $\quad . \quad 1.500 .00$

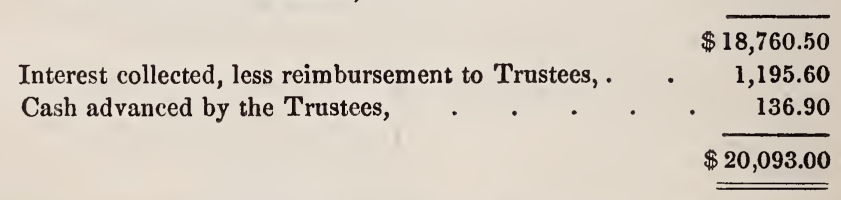

Amount of Bonds purchased by the Trustees, as per last statement, $\quad . \quad \$ 19,000.00$ Amount of Bonds purchased by the Trustees, since last statement, 4,500.00

Amount of Bonds held by the Trustees, . . . . . . $\$ 23,500.00$ Less cash advanced by Trustees, . $\quad . \quad$. $\quad . \quad$. $\quad . \quad$. $\quad . \quad 136.90$

Present amount of the Fund towards the payment of the $\$ 150,000$ issued, . . . . . . . . . . . $\$ 23,363.10$ 


\section{UNION RAILWAY COMPANY.}

THE SIXTH RETURN OF THE UNION RAILWAY COMPANY TO

THE SECRETARY OF THE COMMONWEALTH OF MASSACHUSETTS, - FOR THE YEAR ENDING NOVEMBER 30, 1861, UNDER ACTS OF 1857, CHAPTERS 40 AND 240.

\section{Condition of the Company.}

Capital Stock, fixed by Charter Capital Stock, as voted by the Company,

Capital Stock paid in, in cash,

Capital Stock paid in, in work and materials, by contractors and others,

\section{Funded debt,}

Floating debt,

Amount of above debt secured by mortgage of the road and franchise, or any property belonging to the corporation, or standing in its name,

Number of mortgages on road and franchise, or any property of the corporation, specifying the number and amount of mortgages on road and franchise, and each kind of property,

The amount of capital paid in is $\$ 160,000$.

There is no mortgage on the franchise or any of the property of the company excepting its real estate.

The debt is as follows :-

$\$ 23,500.00$ Balance due on purchases of sundry parcels of real estate, secured by four mortgages and a pledge of the same.

63,641.81 Other debt, which includes the amount of notes payable unsecured; amount due to the stock and bondholders of the Cambridge Railroad Company for accrued rent, not yet payable ; the balances of all personal accounts, and the amount of all unsettled bills, for work performed and materials furnished previous to November 30, 1860.

$\$ 87,141.81$ Total debt. 
Amount of assets on hand, exclusive of the road and equipment, and exclusive of all property, on hand, used, or which is to be used, in running the road and keeping it in repair,
Available assets,

$\$ 101,145.01$

And an interest in the Sinking Fund for the redemption of the Mortgage Bonds of the Cambridge Railroad Company, which, by a statement from the Trustees of said fund appended to the return of said Company, is . .

$23,363.10$

Total, exclusive of the equipment and other property as is hereinafter set forth,

\section{Cost of Equipment.}

Number of cars and cost

Number of horses and cost,

Cost of omnibuses, sleighs, and other vehicles, except. ing cars, owned by the Company, .

Cost of land and buildings thereon when purchased, .

Cost of buildings used for offices, stables, \&c., erected by the Company, or standing on land not owned by the Company, . . . . . . . Cost of other articles of equipment (specifying what) : Harnesses, blankets, \&c., tools, stable furniture, materials to be used in repairing the roads and equipment, office furniture, and provender on hand,

In addition to the above sums, there has been expended and charged to the equipment account, at various times since the Company was organized, for sundry items connected with its operations, including loss on old omnibuses, horses, \&c., construction of switches, turn-outs, tracks to car-houses, \&c., .

Total cost of equipment,

Amount included in the present and in the past years in the running expenses for estimated or actual depreciation of any of the above items.

Net amount at which the equipment stands charged on
554 cars, valued

at $\quad$. $\$ 35,444.41$

322 horses, val-

ued at $\$ 112.50$,

each, : . $36,225.00$

Valued at . $\quad 500.00$

$48,956.59$

Valued at $\quad . \quad 27,027.92$

-

$15,001.25$

$\$ 176,264.86$

The equipment of the Company being entered on its books at the appraised ralue, and not at its cost, charges for depreciation are unnecessary. For an explanation of the plan adopted by the Company in keeping its accounts in this respect, see its returns for the years 1857 and 1858.

the books of the Company, 


\section{DoINGS DURING the Year.}

Total number of miles run during the year,

Number of passengers carried in the cars, .

Rate of speed adopted, including stops and detentions, Rate of speed actually attained, including stops and detentions,

Number of persons employed, regularly (specifying the occupation of each),
597,203

* $2,577,462$

8 miles per hour.

8 miles per hour.

1 President,

1 Treasurer,

1 Clerk,

1 Superintendent,

2 Clerks to do.

3 Overseers of Stables,

34 Conductors, $\uparrow$

1 Starter,

34 Drivers,

3 Mech'ics, Car Repa'rs,

1 " Harn'ss Mak'r,

8 "Blacksmiths.

2 “ Painters,

5 Watchmen,

28 Hostlers,

6 Switchmen,

7 Roadmen,

138 persons regularly employed, Nov. 30,1861 .

Total number of trips run during the year, . . . . . . . 79,320 Average number of passengers each trip, . . . $\left\{\begin{array}{c}32.49, \text { or about } 16 \frac{1}{2} \text { each } \\ \text { way. }\end{array}\right.$

\section{Earnings.}

Received from passengers in cars and omnibuses, and for tickets sold, .

From other roads, as toll or rent for use of road, .

From United States mails,. $\quad . \quad$. $\quad . \quad$. . . 750.00

For sales of manure, . . . . . . . . $1,298.92$

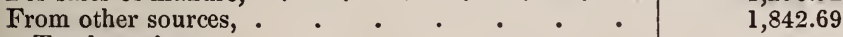

Total earnings, . $\quad . \quad$. . . . . . .

\section{Expenditures For Working the RoAd.}

For repairs of road, including repairs of foundation, renewals of iron, and renewals of pavement, .

For general repairs, including repairs of cars, omnibuses, and harnesses, and for shoeing horses, . . . . . . $\quad$. $5,663.67$

For repairs of real estate, including repairs of buildings used as stables, offices, or for any other purposes, by the Company,

Amount carried forward,

* This includes passengers carried over the Cambridge Road to Watertown, Brighton, and West Cambridge.

$\dagger$ Of this number, 5 conductors are employed by this Company in connection with the lessee of the Newton Railroad (to Brighton), and 4 others in connection with the lessee of the West Cambridge Road. 
Amount brought forward,

$\$ 7,522.38$

For wages, including the wages of every person regularly employed, excepting the President, Directors, Superintendent, and Treasurer, .

For interest, .

For taxes and insurance,

For tolls paid other companies for the right to pass over their roads,

For rent paid other companies for use of their roads,

For provender, - to include cost of hay, grain, straw, or other articles used for the food and bedding of

For miscellaneous articles purchased during the year, - such as harnesses, blankets, \&c., the use of which continues for one or more years, - and not included in the cost of equipment, .

For loss of horses, - that is to say, the difference between the present estimated value of the horses owned by the Company subtracted from the estimated value of those on hand at the commencement of the year, added to the cost of those purchased during the year; or if this is the first report of the Company, then the difference between the estimated value of the horses on hand and their cost, - giving the present average estimated value of each horse.

For incidental expenses, - to include Printing, President, Directors, Treasurer, and Superintendent's salaries, and all expenses other than those belonging to the actual working of the road,

For all other expenses,

For amount charged on the Company's books during the year for estimated or actual depreciation of the following property :-

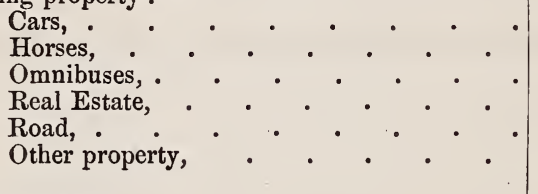

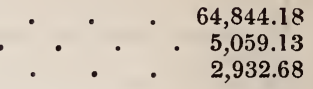

Nothing.

.

Nothing.

Each horse val.

ued at $\$ 112.50,4,902.00$

See remarks un-

der the head-

ing of "Cost of

Equipment."

Total expenses,

Total earnings for the year,

Total expenditures for working the road during the year,

Net earnings after deducting expenses,

Surplus earnings of previous year, on hand, .

Dividends declared during the year,

Total percentage of dividends for the year, . . . 5 per cent.

Present surplus, . 


\section{Miscellaneous.}

Increase during the year, -

Of capital stock, as fixed by the charter,

Of capital stock, as voted by the Company,
Of capital stock paid in,

Increase of funded debt, during the year, Increase of floating debt, during the year,

Decrease of funded debt, during the year, Decrease of floating debt, during the year,

Increase of mortgage debt, during the year, Decrease of mortgage debt, during the year,

Increase in cost of equipment, during the year, including amount charged for depreciation thereon,

Decrease in cost of equipment, by sale of any portion thereof, or by amount charged for depreciation,

Nothing.

The decrease during the year of debt secured by mortgage on the horses is

The decrease during the year of debt secured by mortgage of real estate is $\quad$. $\$ 1,089.60$

Total decrease of secured debt, $\$ 1,089.60$ The increase during the year of unsecured debt is . $\quad 14,341.63$

Net increase of debt, during the year, . . . $\$ 13,252.03$

Nothing. . . . . $\$ 18,294.11$

Nothing.

\section{LIST OF ACCIDENTS ON ROAD DURING THE YEAR.}

August 27, 1861. Run over the foot of a child. Amputation became necessary, and finally resulted in death. The Coroner's inquest acquitted the Company of all blame in the matter.

September 3, 1861. Knocked down and run over a child. The only damage was the loss of one finger. 
The roads operated by this Company being owned by the Cambridge Railroad Company, reference is made to the returns of that Company for replies to the interrogatories included in the blank form of return received from the Secretary of the Commonwealth, under the headings of " Cost of the Road" and "Characteristics of the Road."

Respectfully submitted, by

$\left.\begin{array}{l}\text { H. H. STIMPSON, } \\ \text { CHARLES C. LITTLE, } \\ \text { W. A. SAUNDERS, } \\ \text { ESTES HOWE, }\end{array}\right\} \begin{gathered}\text { Directors } \\ \text { of the } \\ \begin{array}{c}\text { Union Railway } \\ \text { Company. }\end{array}\end{gathered}$

Commonmealty of $\mathfrak{A}$ assacbuset

Middlesex ss.

Cambridge, December 27, 1861.

Then personally appeared the above-named H. H. Stimpson, Charles C. Little, W. A. Saunders, and Estes Howe, and made oath that the foregoing Return, by them signed, is true, to the best of their knowledge and belief.

Before me,

JOSEPH H. CONVERSE, Justice of the Peace. 


\section{R E P O R T}

OF THE

\section{I R E C T O R}

OF THE

\section{CAPE COD RAILROAD}

\section{CORPORATION.}

FOR THE YEAR ENDING NOVEMBER 30, 1861.

BOSTON:

WRIGHT \& POTTER, PRINTERS, 4 SPRING LANE. 1861 . 


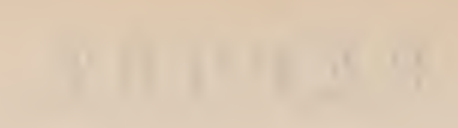

(1) 


\section{REPORT OF THE DIRECTORS}

OF THE

\section{CAPE COD RAILROAD CORPORATION.}

For the year ending November 30, 1861. General Statutes, Chap. 63, Sects. 132 to 135.

1. Capital stock,

2. Number of shares of capital stock issued, .

3. Increase of capital, since last report,

4. Capital paid in, per last report

5. Capital paid in, since last report, .

6. Total amount of capital stock paid in, .

7. Funded debt, per last report,

8. Funded debt, paid since last report,

9. Funded debt, increase of, since last report,

10. Total present amount of funded debt,

11. Floating debt, per last report,

12. Floating debt, paid since last report,

13. Floating debt, increase of, since last report,

14. Total present amount of floating debt, .

15. Total present amount of funded and floating debt, .

16. Average rate of interest $\dot{p}$ er annum, paid during the year,

17. Maximum amount of debts during the year,

\section{Cost of Road and Equipment.}

18. For graduation and masonry, per last report,

19. For graduation and masonry, paid during the past year,

20. Total amount expended for graduation and masonry,

21. For wooden bridges, per last report

22. For wooden bridges, paid during the past year,

23. Total amount expended for wooden bridges,

24. Total amount expended for iron bridges (if any),

25. For superstructure, including iron, per last report,

26. For superstructure, including iron, paid during the past year, .

2\%. Total amount expended for superstructure, including iron,

28. For stations, buildings and fixtures, per last report,

29. For stations, buildings and fixtures, paid during the past year

30. Total amount expended for stations, buildings and fixtures,

31. For land, land-damages and fences, per last report,

32. For land, land-damages and fences, paid during the

33. past year, Total amount expended for land, land-damages and fences,

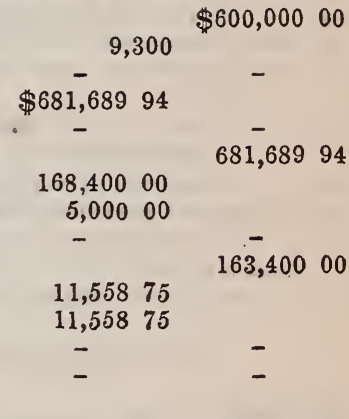

163,40000

6 per cent.

179,95875

$\$ 207,92130$

$30,305 \quad 54$

$\$ 207,92130$

$30,305 \quad 54$

433,12099

433,12099

91,28983

91,28983

76,82396

76,82396 
34. For locomotives, per last report, . .

35. For locomotives, paid during the past year,

$\$ 54,54596$

36. Total amount expended for locomotives,

37. For passenger and baggage cars, per last report,

38. For passenger and baggage cars, paid during the

39. past year, $\quad$ Total amount expended for passenger and baggage cars,

40. For merchandise cars, per last report, :

41. For merchandise cars, paid during the past year, .

42. Total amount expended for merchandise cars,

43. For engineering, per last report, . .

44. For engineering, paid during the past year,

45. Total amount expended for engineering, :

46. Frr agencies and other expenses, per last report, .

47. For agencies and other expenses, paid during the

48. past year, $\quad$ Tutal amount expended for agencies and other expenses, . . . .

49. Total cost of road and equipment,

50. Amount of assets or property held by the corporation in addition to the cost of the road, .

Less amount of unclaimed dividends and balances due from the corporation,

\section{Characteristics of Road.}

51. Length of road,

52. Length of single main track,

53. Length of double main track,

54. Lergth of branches owned by the Company, stating whether they have a single or double track,

55. Aggregate length of sidings, and other tracks, excepting main track and branches,

56. Weight of rail, per yard, in main road,

57. Weight of rail, per yard, in branch roads, (specify the different weights per yard,)

58. Maximum grade, with its length, in main road, .

59. Maximum grade, with its length, in branch roads,

60. Total rise and fall in main road,

61. Total rise and fall in branch roads,

62 . Shortest radius of curvature, with length of curve, in main road,

63. Shortest rodius of curvature, with length of curve, in branch roards,

64. Total degrees of curvature, in main road, .

65. Total degrees of curvature, in branch roads,

66. Total length of straight line, in main road,

67. Total length of straight line, in branches,

68. Aggregate length of wooden truss bridges.

69. Aggregate length of all other wooden bridges,

70. Aggregate length of iron bridges, .

71. Whole length of road unfenced on both sides,

72. Number of public ways crossed at grade, .

73. Number of railroads crossed at grade,

74. Remarks, .

75. Way stations for express trains,

76. Way stations for accommodation trains, .

77. Flag stations,

78. Whole number of way stations, :

79. Whole number of flag stations,

$38,235 \quad 04$

31,08373

31,08373

$\$ 54,54596$

$\begin{array}{cccc}- & - & \\ 21,054 & 95 & 38,235 & 04 \\ - & - & \\ 47,24385 & 2 \overline{1,054} & 95\end{array}$

47,24385

21,05495

$47,243 \quad 85$

$\overline{\$ 1,031,62515}$

$49,675 \quad 33$

5,78248

$\$ 43,89285$

46.01 miles.

46.01 miles.

None.

1.04 miles, single track.

2.70 miles.

56 lbs.

56 lbs.

47.52 feet for 2.79 miles.

40 feet for a small distance.

956.19 feet.

22.00 feet.

$1,432.40$ feet for 1,100 feet.

300 feet for a small distance. 1,147 deg. 26 min. 44 sec.

233 deg.

30.25 miles.

0.21 miles.

179 feet.

434 feet.

$\frac{1}{2}$ mile.

44

None.

None-

13

2

13

2 


\section{Doings During the Year.}

80. Miles run by passenger trains, . . . 59,930

81. Miles run by freight trains, . . . 16,855

82. Miles run by other trains,. $\quad . \quad . \quad . \quad 500$

83. Total miles run, . . . .

84. Number of passengers carried in the cars, .

85. Number of passengers carried one mile, .

86. Number of tons of merchandise carried in the cars,

87. Number of tons of merchandise carried one mile, .

88. Number of passengers carried one mile, to and from other roads,.$\quad \cdot \quad \cdot$

89. Number of tons carried one mile, to and from other roads,

90. Rate of speed adopted for express passenger trains, including stops, .

91. Average rate of speed actually attained by express passenger trains, including stops and detentions,

92. Rate of speed adopted for accommodation trains, .

93. Rate of speed actually attained by accommodation trains, including stops and detentions, .

94. Average rate of speed actually attained by special trains, including stops and detentions, .

95. Average rate of speed adopted for freight trains, including stops, : $\quad . \quad \cdot \quad \cdot$

96. Estimated weight in tons of passenger cars, (not including passengers,) hauled one mile,

97. Estimated weight in tons of merchandise cars, (not including freight,) hauled one mile,

80,873

$1,957,371$

21,906

386,408

$1,710,237$

292,471

23 miles per hour.

23 miles per hour.

14 miles per hour.

$1,500,000$

500,000

\section{Expenditures for Working the Road.}

98. For repairs of road, maintenance of way, exclusive of wooden bridges, and renewals of iron, .

99. For repairs of wooden bridges,
100. For wages of switchmen, average per month, $\$ 30$, . $\quad \$ 72000$

101. For wages of gate-keepers, average per month, \$4.17, .

102. For wages of signal-men, average per month, .

103. For wages of watchmen, average per month, $\$ 30$, Number of men employed, exclusive of those engaged in construction, .

105. For removing ice and snow, (this item to include all labor, tools, repairs, and extra steam-power used,)

106. For repairs of fences, gates, houses for signal-men, gate-keepers, switchmen, tool-houses, .

107. Total for maintenance of way,

\section{Motrve Power aNd Cars.}

108. For repairs of locomotives,

109. For new locomotives, to cover depreciation,

110. For repairs of passenger cars,

111. For new passenger cars, to cover depreciation, : 
112. For repairs of merchandise cars, .

$\$ 6,65973$

113. For new merchandise cars, to cover depreciation,

114. For repairs of gravel and other cars,

115. Total for maintenance of motive power and cars,

116. Number of engines,

117. Number of passenger cars,

118. Number of baggage cars, .

119. Number of merchandise cars

120. Number of gravel cars, .

\section{Miscellaneous.}

121. For fuel used by engines during the year, viz. :1. Wood, number of cords, 876 . Cost of the same,

2. Coal, number of tons, (reckoning $2,240 \mathrm{lbs}$. to the ton,) 416. Cost of same,

122. For oil used by cars and engines,

123. For waste and other material for cleaning,

124. For salaries, wages and incidental expenses, chargeable to passenger department,

125. For salaries, wages and incidental expenses, chargeable to freight department,

126. For gratuities and damages,

127. For taxes and insurance,.

128. For ferries,

129. For repairs of station buildings, aqueducts, fixtures, furniture,

130. For renewals of iron and sleepers, laying down, included in road repairs,

131. For new iron laid down, deducting the value of old iron taken up,

132. For amount paid other companies, in tolls for passengers and freight carried on their roads, specifying each company,

133. For amount paid other companies, as rent for use of their roads, specifying each company, .

134. For salaries of president, treasurer, superintendent, law expenses, office expenses of the above offices, and all other expenses not included in any of the foregoing items,

135. Total miscellaneous, .

136. Total expenditures for working the road,

137. Total amount of interest paid during the year,

\section{Income DURING THe YeaR.}

138. For Passengers :-

1. On main road, including branches owned by

2. To and from other roads, specifying what,

139. For Freight:-

1. On main road and branches owned by com-

2. To and from other connecting roads,

140. U. S. Mails,

141. . • . . . $\quad 5,50000$

$\begin{array}{llll} & \cdot & \cdot & \cdot\end{array}$

$\$ 32,68530$

$\$ 61,79963$

10,65523

$\$ 72,33553$

$17,240 \quad 43$

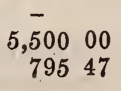




\section{Drvidends.}

144. Per cent. Total, .

145. Surplus not divided,

146. Surplus last year,

-

147. Total surplus, which has been applied towards the payment of the debts of the Company,

Estimated Depreclation beyond the Renewals, VIZ.:-

148. Road and bridges,

149. Buildings,

150. Engines and cars,

\section{Mortgage Debts.}

151. Amount of debts, secured by mortgage of road and franchise, or any property of the corporation, per last report,

152. Mortgage debt, paid since last report,

153. Increase of mortgage debt, since last report,

154. Present amount of mortgage debts,

155. Number of mortgages on road and franchise, or any property of the corporation,

Accident. October 2, 1861. Patrick Foley stepped or fell from a passenger car, as the train was leaving the Parker Mills station, and was fatally injured.

J. H. W. PAGE, BENJAMIN BURGESS, RICHARD BORDEN, ALEXANDER BAXTER, NATHANIEL S. SIMPKINS, MATTHEW STARBUCK,

Directors of the Cape Cod Railroad Corporation.

Sufrolk, ss. December 20, 1861. Then personally appeared said J. H. W. Page, Benjamin Burgess, Richard Borden, Alexander Baxter, Nathaniel S. Simpkins, and Matthew Starbuck, and severally made oath to the truth of the foregoing statement, by them subscribed.

\section{Before me,}

WILLIAM STOWE, Justice of the Peace. 



\section{SECOND ANNUAL REPORT}

\section{OF THE DIRECTORS OF THE \\ OTliftondale liailroad Crompam.}

Second Annual Report of the Directors of the Cliftondale (Horse) Railroad Company, for the year ending November 30, 1861.-General Statues, Chap. 63, Sect. $143-144$.

\section{Condition of the Company.}

1. Capital Stock, fixed by charter, -

$\$ 150,000$

¿. Capital Stock, as voted by the Company, - $\quad 70,000$

3. Capital Stock paid in in cash, - - - 70,000

4. Capital Stock paid in, in work and materials, by contractors and others, - $\quad-\quad-$ None.

5. Funded debt, - - - - - $\quad$ - 24,500

6. Floating debt, $\quad-\quad-\quad-\quad-\quad-\quad 2,850$

7. Total debt, - $\quad$ - $\quad-\quad-\quad 27,350$

8. Amount of above debt secured by mortgage of the road and franchise, or any property belonging to the corporation, or standing in its name, - - - - - 25,850

9. Number of mortgages on road and franchise, or 1 One mortgage on road for any property of the corporation, specifying $\left(\begin{array}{l}\text { Ond } \\ \$ 25,000-\$ 500 \text { of which is }\end{array}\right.$ $\left.\begin{array}{l}\text { the number and amount of mortgages on } \\ \text { road and franchise, and each kind of prop- }\end{array}\right\} \begin{aligned} & \$ 2,000 \text { sid to sinking fund, } \\ & \text { paine } \\ & \text { one on }\end{aligned}$ erty,

10. Amount of assets on hand, exclusive of the one on cars for $\$ 1350$. road and equipment, and exclusive of al property on hand, used, or which is to be used, in ruming the road and keeping it in repair, None.

\section{COST OF THE ROAD.}

11. Amount expended for labor in excavating for the track, laying foundation and rails,

12. Amount expended for timber for foundation,

13. Amount expended for iron and other metal for rails, chairs, spilies, or other articles, used in building the road,

11. Amount expended for paving

15. Amount expended for paving

16. Amount expended for engineering, - -

17. Amount expended for interest, salaries of officers during construction of road, and other expenses not ineluded in any of the above items, which have been included, on the books of the Company, in the cost of the road, not including items of equipment or running expenses, as mentioned below,
This railroad was built by contract and the items are unknown to the Company. The contract included the construction of the road into Lynn, which has not been built, because no location has yet been granted by the anthorities of that city, and awaiting the decision upon an application for that location, no final settlement has been make with the contractor. 
18. Total cost of roaci, - - - - $\$ 95,500$

19. Amount included in the present and in past years, among the running expenses for estimated or actual depreciation of the road,

20. Net cost of road,

None.

$\$ 9$ i), 500

\section{Cost of Equipment.}

21. Number of cars and cost,

3 Cars $\$ 1350$.

23. Cost of omnibuses, sleighs and other vehicles, excepting cars, owned by the Company,

24. Cost of land and building thereon when pur(hased,

25. Cost of buildings used for offices, stables, \&c., erected by the Company, or standing on land not owned by the Company,

26. Cost of other articles of equipment, (specifying what,)

27. Total cost of equipment,

29. Amount included in the present and in past years in the running expenses for estimated or actual depreciation of any of the above items - - - - - $\quad$ - $\quad$ - None.

29. Net amount at which the equipment stands charget on the books of the ermpany,

$\$ 1350$ for cars as above.

CharaCteristics OF THE ROAD.

30. Length of single main track,

31. Length of double main track, -

32. Total lenerth of road, -

33. Length of branches owned by the Company, stating whether they have a single or double track,

th of switclies, sidings, turnouts and other track, excepting main track anc branches,

35. Totol length of rail,

i Rolied iron $7 \frac{1}{2}$ lbs., a strap

36. Weight of rail used, per yard, (specifying, whether of cast or rolled iron,) -

This railroad was run by the Maiden and Melrose Railroad Company, they furnishing stables, offices and all the equipment, till Nov. 1st, $186 \mathrm{l}$. Since Nov. 1st. it has been mn by Benj. Hibbarl lie fuxnishings all but cars.

37. Maximum grade per mile on road, with length of́t gade, - -

curve, - - - - - 75 feet for 113 feet.

39. Greatest length of single track on road between two iminouts,

40. Total length of main track which is paved,

\section{Doings Durixg tile Tear.}

41. Total number of miles run during the year,

42. Number of passengers carried in the cars,

43. Rate of speed adopted, including stops and detentions,

44. Rate of speed actually attained, including stops and detentions,

45. Number of persons employed, regularly, (specifying the occupation of each,)

46. Total number of trips run during the year,

47. Average number of passengers each trip

About 11,00 feet. rail bolted and spiked npon longinudinal imbers-cast iron 80 llus.

Expenditures For WORKING THE ROAD.

48. For repaits of road, including repairs of foun-

The Company has no means of knowing. 
dation, renewals of iron, and renewals of pavement, omnibusses and harnesses, and for shoeing horses,

50. For repairs of real estate, inchding repairs of buildings used as stables, offices, or for any other purposes, by the Company, -

Paid by lessees.

51. For wages, including the wayes of every persoll regularly employed, excepting the President, Directors, Superintencient and Treasurer, -

President, Direetors, Superintendant and Treasurer.

52. For interest,

53. For taxes and insurance,

54. For tolls paid other companies for the right to Nothing. pass over their roads,

55. For rent paid otler companies for use of their roads, -

56. For provender,- to include cost of hay, grain, straw, or other articles used for the food and bedaing of horses,

57. For miscellaneous articles purchased during the year-snch as harnesses, blankets, \&ce, the use of which continues for one or more years -and not included in the cost of equipment,

58. For loss on horses-that is to say, the difference between the present extimated value of the horses owned by the Company, substracted from the estimated value of those on hand at the commencement of the year, added to the cost of those purchased during the year; or: if this is the first report of the Company, then the difference between the estimated value of the hurses on hand and their cost-giving the present average estimated value of each loorse,

59. For incidental expenses, - to include, printing, President's, Directors', Treasurer's and Sitperintendent's salaries, and ail expenses other than those belonging to the actual work-

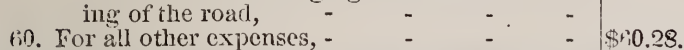

61. For amount charged on the Company's hooks None.

rimring the year, for esiminted or actual depreciation of the following property :Cars, -

Horses,

Onmibuses, -

Real listate, -

Roarl, -

Other property,

62. Total expenises. -

Paid by lessees.

$\begin{array}{lll}\text { lroperty : } & \\ - & - & \$ \\ - & - & - \\ - & - & - \\ - & - & - \\ - & - & - \\ - & - & - \\ - & - & -\end{array}$

\section{Earitings.}

63. Received from passengers in cars and omnibuses, and for tickets sold,

64. From other roals, as coll or rent for use of road,

65. From United Srates mails,

66. For sales of manure,

67. From other sourees,

$-$

68. Total earnings, -

69. Net earnings, after deducting expenses,

70. Surplus earnings of previous year on hand,

71. Net eaming's, as_above,
- Nothing.
There has been received from the lesses for rent $\$ 1240$. 
72. Total surplus for payment of dividends,

73. Dividends declared, during the year, - .

74. Total percentage of dividends, for the year,

75. Present surpius,

\section{Miscellaneous.}

76. Increase during the year-

Of capital stock, as fixed by the charter, -

Of capital stock, as voted by the Company,

Of capital stock, paid in,

77. Increase of funded debt, during the year,

78. Increase of floating debt, during the year, -

79. Decrease of funded debt, during the year,

80. Decrease of floating debt, during the year, -

81. Increase of mortgage debt, during the year, -

82. Decrease of mortgage debt, luring the year,

83. Increase in cost of road, during the year, including amount charged for depreciation thereon

84. Decrease in nominal cost of road, by amount

charged for depreciation thereon, - - None.

85. Increase in cost of equipment, during the year, including the amount charged for depreciation thereon,

86. Decrease in cost of equipment, by sale of any portion thereof, or by amount charged for depreciation,

87. List of accidents on road during year,

- None.

None.

None.

$\$ 20,000$

$\$ 39,900$

None.

(1)

$\$ 500$ paid into sinking fund.

None.

$\$ 850$

See answer to No. 79.

Road in process of construetion last year and no return made of its cost.

$\$ 1350$

A. W. BOARDMAN, A. W. BOARDMAN, A. E. JOHONNOT,
EBENEZER W. STONE,

Directors of the Cliftondale Railroad Co.

Sufrour ss., December 31,1861 . Then personally appeared the above named Bordman, J. M. Stone and Johonnot and E. W. Stone, and severally made oath to the truth of the foregoing statement by them subscribed, according to the best of their knowedge and belief.

Before

WM. J. EAMES, Justice of the Pcace. 


\section{Seventeenth Annual Report}

- OF THE-

CONNECTICUT RIVER RAILROAD COMPANY. 



\section{SEVENTEENTH ANNUAL REPORT}

OF THE

\section{Connecticut River Railroad Company,}

FOR THE YEAR ENDING NOV. 30, 1861.

Report of the Connecticut River Railroad, under the General Statutes, Chapter 63 , Sections 132 to 135 .

Capital Stock,

Number of shares of capital stock issued, . Increase of capital, since last Report,

Capital paid in, per last Report,

Capital paid in since last Report,

Total amount of capital stock paid in, .

Funded debt; per last Report.

Funded debt paid since last Report, . .

Funded debt, increase of, since last Report, .

Total present amount of funded debt, .

Floating debt, per last Report,

Floating debt paid since last Report,

Floating debt, increase of, since last Report,

Total present amount of floating debt,

Total present amount of funded and floating debt, *

Average rate of interest per annum, paid during the year,

Maximum amount of debts diring the year,

\section{Cost of RoAD aND EQUIPMENT.}

For graduation and masonry, per last Report, For graduation and masonry, paid during the past year,

Total amount expended for graduation and masonry,

For wooden bridges, per last Report,

For wooden bridges, paid during the past year,

Total amount expended for wooden bridges.

Total amount expended for iron bridges, (if any,)

For superstructure, including iron, per last Report,

For superstructure, including iron, paid during the past year,

Total amount expended for superstructure, including iron,

For stations, buildings and fixtures, per last Report,

For stations, buildings and fixtures, paid during the past year,

* For the payment of $\$ 50,000$, due in 1863 , the money is already provided and invested. The balance of $\$ 250,000$ is in mortgage bonds due Sept. 1, 1878, for the redemption of which a sinking fund is established, to which, the [first] annual contribution of $\$ 8,000$ from the earnings of the road, was made Sept. 1,1861 .
15911

$\$ 1,750,000,00$

\section{None.}

$\$ 1,591,100,00$

None.

$320,000,110$

$20,000,00$

None.

None.

None.

None.

None.

$300,000,00$

Six per cent.

$331,9001,00$

\section{$\$ 513,242,93$}

Nothing.

$$
\text { 42,991,94 }
$$

Nothing.

$$
42,991,94
$$

No iron bridges.

$$
545,287,61
$$

Nothing.

$$
545,28 \%, 61
$$

\section{$121,484,85$}

Nothing: 
Total amount expended for stations, buildings and fixtures,

For land, land-damages and fences, per last Report,

For land, land-damages and fences, paid during the past year,

Total amount expended for land, land-damaages and fences, .

For locomotives, per last Report, . $\quad$.

For locomotives, paid during the past year, . Total amount expended for locomotives,

For passenger and baggage cars, per last Report,

For passenger and baggage cars, paid during the past year,

Total amount expended for passenger and baggage cars,

For merchandise cars, per last report,

For merchandise cars, paid during the past year, Total amount expended for merchandise cars,

For engineering, agencies and other expenses, per last Report,

For engineering, agencies and other expenses, paid during the past year,

Total amount expended for engineering, agencies and other expenses,

Total cost of road and equipment,

Amount of assets or property held by the corporation in addition to the cost of the road,

\section{Characteristics of Road.}

Length of Road,

Length of single main track,

Length of branches owned by the Company, stating whether they have a single or double track,

Aggregate length of sidings, and other tracks, excepting main tracks and branches,

Weight of rail, per yard, in main road,

Weight of rail, per yard, in branch roads, . Specify the different weights per yard,

Maximum grade, with its length, in main road,

Maximum grade, with its length, in branch roads,

Total rise and fall in main road,

Total rise and fall in branch roads,

Shortest radius of curvature, with length of curve in main road,

Shortest radius of curvature, with length of curve, in branch roads,

Total degrees of curvature, in main road, :

Total degrees of curvature, in branch roads,

Total length of straight line, in main road, .

Total length of straight line, in branches, .

Aggregate length of wooden truss bridges, :

Aggregate length of all other wooden bridges,

Aggregate length of iron bridges,
$121,484,85$

$229,407,18$

Nothing.

$81,982,87$

$229,407,18$

Nothing.

$81,982,87$

$23,350,34$

Nothing.

$82,225,28$

Nothing.

$82,225,28$

$161,970,80$

Nothing.

$161,970,80$

$\$ 1,801,943,80$

$\$ 142,203,08$

50 miles.

50 miles.

None except for turnouts.

2 35-100 miles single track.

48,840 feet.

$\{7$ miles, 50 lbs., 33 miles, $\{56$ lbs.; balance, 61 lbs. $56 \mathrm{lbs}$.

$50 \mathrm{lbs}$., $56 \mathrm{lbs}$. and $61 \mathrm{lbs}$.

32 feet per mile for $6 \frac{1}{2}$ miles.

18 feet per mile for $1 \frac{1}{2}$ miles. 680 feet.

28 feet.

882 feet radius, $889 \mathrm{ft}$. long.

714 feet radius, $1300 \mathrm{ft}$.long.

$1854^{\circ}$

$449^{\circ}$

$35_{2}^{1}$ miles.

1 mile.

2,674 feet.

100 feet, pile bridge.

None. 
Whole length of road unfenced on both sides, Number of public ways crossed at grade, Number of rail roads crossed at grade,

Remarks,

Way stations for express trains,

Way stations for accommodation trains,

Flag stations,

Whole number of way stations,

Whole number of flag stations,

\section{DOINGS DURING THE YeAR.}

Miles run by passenger trains,

Miles run by freight trains,

Miles run by other trains,

Total miles run,

Number of passengers carried in the cars,

Number of passengers carried one mile,

Number of tons of merchandise carried in the cars,

Number of tons of merchandise carried one mile,

Number of passengers carried one mile, to and from other roads,

Number of tons carried one mile, to and from other roads, .

Rate of speed adopted for express passenger trains, including stops,

Average rate of speed actually attained by express passenger trains, including stops and detentions,

Rate of speed adopted for accommodation trains,

Rate of speed actually attained by accommodation trains, including stops and detentions,

Average rate of speed actually attained by special trains, including stops and detentions,

Average rate of speed adopted for freight trains, including stops,

Estimated weight in tons of passenger cars, (not including passengers,) hauled one mile,

Estimated weight in tons of merchandise cars, (not including freight,) hauled one mile, .

\section{EXPENDITURES FOR WORKING THE ROAD.}

For repairs of Road, maintenance of way exclusive of wooden bridges, and renewals of iron,

For repairs of wooden bridges,

For wages of switchmen, average per month, $\$ 30.00$,

For wages of gate-keepers, average per month, $\$ 20.10$.

For wages of signal-men, average per month, \$ - - .

For wages of watchmen, average per month, 35.00 .

Number of men employed, exclusive of those engaged in construction,
None.

55.

None.

No express trains run.

15.

None.

15.

None.

92,242

57,770

12,298

162,310

$298,376 \frac{1}{2}$

$3,570,919$

105,587

2.325,211

$1,264,810$

$1,744,025$

)

No express trains run.

25 miles per hour.

22 miles per hour.

12 miles per hour.

\$ $30,660,06$

957,44 
For removing ice and snow, (this item to include all labor, tools, repairs, and extra steam-power used,)

For repairs of fences, gates, houses for signalmen, gate-keepers, switchmen, tool-houses, Total for maintenance of way,

\section{Motive Power and Cars.}

For repairs of locomotives,

For new lncomotives, to cover depreciation, .

For repairs of passenger cars, (including rebuilding three,)

For new passenger cars, to cover depreciation, For repairs of merchandise cars, (including rebuilding five,)

For new merchandise cars, to cover depreciation, For repairs of gravel and other cars,

[For repairs of tools and machinery,] Total for maintenance of motive power and cars,

Number of engines,

Number of passenger cars, (12 eight wheel, 1 four wheel,)

Number of baggage cars, ( 5 eight wheel, 1 four wheel,),

Number of merchandise cars, (70 Long House, 79 Long Platform, 1 Short House,)

Number of gravel cars, (26 Short Platform,)

\section{Miscellaneous.}

For fuel used by engines during the year, viz. : Wood, number of cords, 3844 12-128. Cost of the same,

Coal, number of tons, (reckoning $2,240 \mathrm{lbs}$. to the ton,) -.. Cost of Coal, .

For oil used by cars and engines,

For waste and other material for cleaning, .

For salaries, wages, and incidental expenses, chargeable to passenger department,

For salaries, wages, and incidental expenses, chargeable to freight department, .

For gratuities and damages, . .

For taxes and insurance, . . .

For ferries, . • • •

For repairs of station buildings, aqueducts, fixtures, furniture,

For renewals of iron, including laying down,

For new iron laid down, deducting the value of old iron taken up,

For amount paid other companies, in tolls for passengers and freight carried on their roads, specifying each company, .

For amount paid other companies, as rent for use of their roads, specifying each company,

For salaries of president, treasurer, superintendent, law expenses, office expenses of the above offices, and all other expenses not included in any of the foregoing items, Total Miscellaneous,

Total expenditures for working the road,
$\$ 2,104,04$

$\$ 33,721,54$

$\$ 6,757,59$

$4,698,51$

$6,625,11$

86,34

$1,798,37$

12

$\{13$

$\{6$

\{

$325-4$ wheel.

$\$ 19,965,92$

$\$ 13,076,05$

No coal used.

$1,346,42$

488,98

$16,119,18$

$21,075,96$

403,84

1,289,63

$3,439,98$

$8,876,50$

(See next page.)

$8,076,39$

$\$ 74,192,93$

$\$ 127,880,39$ 


\section{INCOME DURING THE YEAR.}

\section{For Passengers :-}

On main road, including branches owned [and hired] by company,

For Freight:-

On main road and brarches owned [and hired] by company,

U. S. Mails, \$6,254,10; Express, $\$ 3,650,00$,

Rents,

Total income,

Net earnings, after deducting expenses,

Interest,

First Contribution to Sinking Fund,

Rent of Astuelot Railroad, for quarter ending Dec. $31,1860$.

Value of Ashuelot Outfit and Equipment transferred to our own road,

\section{DIVIDENDS.}

Six per cent. Total, .

Surplus not divided,

Surplus, per last year's Report.

Surplus last year, after settlement of Asliuelot lease, Total surplus,

\section{Moritgage Debts.}

Amount of debts secured by mortgage of road and franchise, or any property of the Corporation, per last Report,

Mortgage debt, paid since last Report

Increase of mortgage debt, since last Report, Present amount of mortgage debt,

Number of mortgages on road and frunchise, or any property of the Corporation,
$\$ 121,832,60$

$116,979,34$

$9,904,10$

$2,119,96$

$\$ 250,836,00$

$122,955,61$

$\$ 13,993,25$

$8,04: 0,00$

$7,560,100$

$20,888,17$

$\$ 95,466,00$

$\cdot 2,996,36$

$75,938,59$

$50,050,52$

$5: 3,146,88$

$\$ 250,000,00$

None.

None.

$250,(100), 00$

One.

\section{RECORD OF ACCIDENTS}

On the Connecticut River Rail Road, for the year ending Nov, 30, 1861.

January 24.-Luther Dickinson of Northampton, Engineer. The evening Passenger train down, drawn by two locomotives, was thrown from the track, by ice on the rails under a snow drift, near Holyoke Dan. Mr. Dickinson was thrown from the forward locomotive, eaught between the tender and a ledge of rocks, and instantly killed.

June 1u.-Major Colby of Springtield, a Hotel Porter, in attempting to get upon the evening Passenger train, as it was entering the depot at Springfield, fell between the cars, and was instantly killed. 
July 13.-William McKinney, 7 years old, son of Robert McKinney of Chicopee, was at play in the first bridge above Chicopee. When the A. M. Passenger train approached, he ran out of the bridge, and was struck by the locomotive while crossing the track. He died five days after.

October 8.-H. M. Smith of Holyoke, jumped from an extra Passenger train, while in motion, at Chicopee. A car passed over both feet. The toes of one foot were amputated the same night. Amputation of a leg took place on the 21st of October, and he died on the 22d.

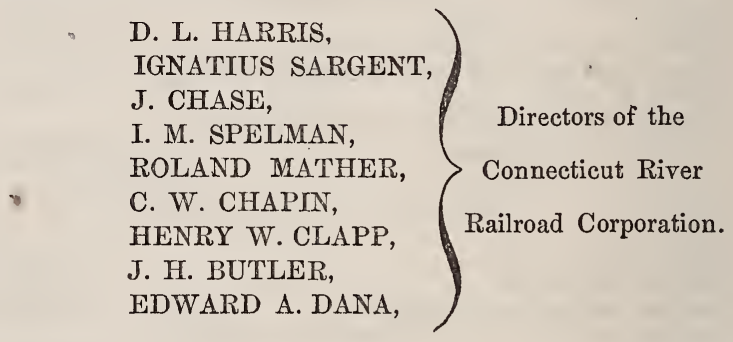

SufFolK sS., December 24, 1861. Then personally appeared D. L. Harris; Ignatius Sargent, J. Chase, I. M. Spelman, Roland Mather, C. W. Chapin, Henry W. Clapp, J. H. Butler, Edward A. Dana, and severally made oath to the truth of the foregoing statement by them subscribed.

Before me,

STEPHEN FAIRBANKS, Justice of the Peace. 


\title{
T H I R D
}

\section{A N N U A R R P O R T}

OF THE

\section{DORCHESTHR}

\section{EXTENSHON RAILWAY}

\section{COMPANY,}

\author{
1861.
}

\section{B O S T O N :}

WILLIAN BENSE, PRINTER, MONKS BUILDING, 8 CONGRESS SQUARE, 1861 . 


\section{DORCHESTER EXTENSION RAILWAY CORPORATION.}

For the Year ending Nov. 30, 1861.

\section{Condition of the Company.}

Capital Stock, fixed by charter,

Capital Stock, as roted by the Company, .

Capital Stock paid in, in cash, . . .

Capital Stock paid in, in work and materials, by contractors and others,

.......

Funded debt,

Floating debt,

Total debt,

Amount of debt secured by mortgage of the road and franch se or any property belonging to the Corporation, or standing in its name,

Number of mortgages on road and franchise, or any property of the Corporation, specifying the number and amount of mortgages on road and franchise, and each kind of property,

Amount of assets on hand, exclusive of the road and equipment, and exclusive of all property on hand, used, or which is to be used, in running the road and keeping it in repair,

\section{Cost of the Road.}

Amount expended for labor in excavating for the tra $k$, laying foundation and rails,

Amount expended for timber for foundation, .

Amount expended for iron and others metals for rails, chairs, spikes, or other articles, used in building the road, .

Amount expended for paving, . . . . .

Amount expended for paving stones, . . Amount expended for ençineering, . . .

Amount expended for interest, salaries of officers during the construction of road and other expenses not included in any of the above items, which have been included, on the books of the company, in the cost of the road, not including items of equipment or running expenses, as mentioned below.

Total Cost of Road, . . . . . . .

Amount included in the present and past years, among the running expenses for estimated or actual depreciation of the road,

Net cost of the road, . 


\section{Cost of Equipment.}

Number of cars and cost, . . . . ,

Number of horses and cost, . $. \quad . \quad$.

Cost of omnibuses, sleighs and other vehicles, exeepting ears owned by the Company, . .

Cost of land and builåings thereon when purchased,

Cost of buildings used for offices, stables, \&c., erected by the Company, or standing on land not owned by the Company, . . . . .

Cost of other articles of equipment (specifying what, )

Total cost of equipment,

Amount included in the present and in past years in the running expenses for estimated or actual depreciation of any of the above items,

Net amount at which the equipment stands charged on the books of the Company,

\section{Characteristics of the Road.}

Length of single main track,

No equipment or buildings are owned by the Company.

Length of double main track, .

Total length of road, . $\quad . \quad$. $\quad . \quad . \quad$. 7830 feet.

Length of branches owned by the Company, stating whether they have single or double track, $\left.\begin{array}{c}\text { Aggregate length of switches, sidings, turnouts and } \\ \text { other track, excepting main track and branches, }\end{array}\right\} \begin{gathered}\text { Two turnouts and sidings, } 328 \\ \text { feet. }\end{gathered}$

Total length of rail, . . . . . . 8158 feet.

Weight of rail used, per yard, (specitying whethes of cast or rolled iron,) . . . . . .

Maximum grade, per mile on road, with length of $\} 21120-100$ ths feet per mile. 900 grade, . . . . . . . $\}$ feet.

Shortest radius of curvature, with length of curve, 260 feet radius, 96 feet length.

Greatest length of single track on road betweer two turnouts,

Total lengtlı of main track which is paved, -

\section{Doings During the Year.}

Total number of miles run during the year, .

Number of passengers carried in the cars, .

27375 miles.

122275.

Rate of speed adopted, including stops and detentions,

Rate of speed actually attained, including stops and detentions,

Number of persons employed regularly, (specifying the occupations of each,) .

Total number of trips run during the year, .

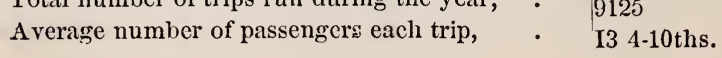


Expendtures for Working the RoAd.

For repairs of road, including repairs of foundation, renewals of iron, and renewals of pavement,

For general repairs, including repairs of cars, omnibuses and harnesses, and for shoeing horses,

For repairs of real estate, including repairs of buildings used as stables, offices or for any other purposes, by the Company,

For wages, including the wages of every person regularly employed, excepting the president, directors, superintendent and treasurer, . .

For interest,

For taxes and insurance, . . . . .

For tolls paid other companies for the rightt to pass over their roads,

For rent paid other companies for use of their roads, For provender,- to include cost of hay, grain, straw or other articles used for food and beddiug of horses,

For miscellaneous articles purchased during the year-such as harnesses, blankets, \&c., the use of which centinues for one or more years-and not included in the cost of equipment, .

For loss on horses-that is to say, the difference between the present estimated value of the horses owned by the Company subtracted from the estimated value of those on hand at the commencement of the year, added to the cost of those purchised during the year; or if this is the first report of the Company, then the difference between the estimated value of the horses on hand and their cost, - giving the present average estimated value of each horse,

For incidestal expenses, - to include printing, president's, directors', treasurer's, and superintendent's salaries, and all expenses other than those helonsing to the actual working of the road,

For all other expenses, . , . . .

For amount charged on the Company's books during the year, for estimated or actnal depreciation of the following property :-

Cars,

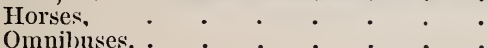

Real Estate, $\quad: \quad: \quad: \quad: \quad \vdots \quad$

Road, : $: \quad \cdot \quad: \quad$ :

Other Property, . . . . . .

Total, . . . . . .

Total expenses, . . . . . .

EARNINGS.

Received from passengers in cars and omnibuses, and for tickets sold,
This road, at its completion, was leased to Messrs. Gore, Rose \& Company, of Boston, lessees of the Dorchester Railway, who run the cars on their own account, and pay to this Corporation a rent equal to eight per cent. per annum on the amount of stock outstanding. 
From other roads, as toll or rent for use of road,

From United States mails,

For sale of manure,

From other sources

Total earnings, .

Surplus earnings of previour year, on hand, .

Net earnings, as above, . . . . .

Total surplus for payment of dividends, . .

Dividends declared, during the year, . .

Total percentage of dividends, for the year, .

Present surplus,

\section{Miscellaneous.}

Increase during the year-

Of capital stock, as fixed by the charter, .

Of capital stock, as voted by the Company,

Of capital stock, paid in, . . . .

Increase of funded dent, during the year, .

Increase of floating debt, during the year, .

Decrease of funded debt, during the year, .

Decrease of floating debt, during the year,

Increase in cost of road, during the year, including amount charged for depreciation thereon, .

Decrease in nominal cost of road, by amount charged for depreciation thereon,

Increase in cost of equipment, during the year, indluding amount charged for depreciation thereon,

Decrease in cost of equipment, by sale of any portion thereof, or by amount charged for depreciation,

List of accidents on road during the year, . None.
$\$ 1024,00$

$\$ 1024,00$

$\$ 1024,00$

8 per cent.

\section{Respectfully submitted, \\ CHEFVER NEWHALL, STANLEY GORE, DAVID GORE,}

\section{COMMONWEALTH OF MASSACHUSETTS.}

SufFolk ss. Boston, December 30, 186t. Then personally appeared Cheever Newhall, Stanley Gore, and David Gore, and severally made oath to the truth of the foregoing statement by them subscribed,

Before me,

J. M. PINKERTON, Justice of the Peace. 



\title{
FOURTH ANNUAL REPORT
}

\author{
- $\quad$ OF THE \\ DORCHESTER RAILWAY \\ COMPANY.
}

1861.

B O S T O N :

WRIGHT \& POTTER, PRINTERS, 4 SPRING LANE.

1861 . 


\section{REMARKS.}

The Dorchester Railway Company was organized under the provisions of chapter 279 of the Acts of the year 1856, and purchased the corporate property of the Dorchester Avenue Railroad Company, at a sale ordered by a decree of the Supreme Judicial Court, in January, 1858. The road has been leased to Messrs. Gore, Rose \& Company, of Boston, who purchased the entire equipment, and have run the cars and the line of coaches connected therewith, since June 1, 1858, on their own account, paying a rent equal to eight per cent. per annum on the amount of stock outstanding, and also the taxes and insurance on the buildings. They are also bound under their lease to make good any depreciation in the road, and to keep it throughout in perfect repair. During the year 1860, a branch was built, (under contract with the Dorchester Extension Railway Company for that part of it lying in Dorchester,) extending from the main road at Washington Village, in South Boston, to Washington Street, in Dorchester. The total cost of this branch was $\$ 18,200$. A double track in South Boston, from Broadway to Washington Village, has been located; and it is now constructed, and is in use, for about one-half the distance. 


\section{FOURTH ANNUAL REPORT}

OF THE

\section{DORCHESTER RAILWAY COMPANY.}

For the year ending November 30, 1861, under the General Statutes, Chapter 63.

\section{Condition of the Compant.}

1. Capital Stock, fixed by Charter,

. Capital Stock, as voted by the Company, .

3. Capital Stock paid in, in cash

4. Capital Stock paid in, in work and materials, by contractors and others, .

5. Funded debt, (secured by mortgage,) .

6. Floating debt, - • •

7 . Total debt, . $\quad . \quad 5 \quad$. $\quad$ :

8. Amount of above debt secured by mortgage of the road and franchise, or any property belonging to the corporation, or standing in its name,

9. Number of mortgages on road and franchise, or any property of the corporation, specifying the number and amount of mortgages on road and franchise, and each kind of property, .

10. Amount of assets on hand, exclusive of the road and equipment, and exclusive of all property on hand, used, or which is to be used, in running the road and keeping it in repair, .

\section{Cost of the Road.}

11. Amount expended for labor in excavating for the track, laying foundation and rails,

12. Amount expended for timber for foundation,

13. Amount expended for iron and other metal for rails, chairs, spikes, or other articles, used in building the road,

14. Amount expended for paving

15. Amount expended for paving stones,

16. Amount expended for engineering,

17. Amount expended for interest, salaries of officers during construction of road, and other expenses not included in any of the above items, which have been included, on the books of the company, in the cost of the road, not including items of equipment or running expenses, as mentioned below,

18.

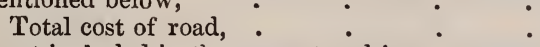

19. Amount included in the present and in past years, among the running expenses for estimated or actual depreciation of the road,

$\$ 116,20000$

$99,765 \quad 37$

10,73463

5,00000

1,46448

6,46448

$\$ 5,000$ of the above debt secured by mortgage of real estate in South Boston; there is no other mortgage or lien on the property or franchise of the corporation.

$\$ 2,086.56$; out of which sum the whole floating debt will be paid when due in December, 1851.

The original cost of construction is the same as returned by the Dorchester Avenue Railroad Company, of whom it was purchased after its completion, viz. :

$\$ 118,15042$

To which add cost of new branch built in 1860 , under contract, 18,20000

And of the double track in South Boston, 9,998 41

$\$ 146,348 \quad 83$

20. Net cost of road, . 


\section{Cost of Equipment.}

21. Number of cars and cost, .

22. Number of horses and cost,

23. Cost of omnibuses, sleighs and other vehicles, excepting cars, owned by the Company,

24. Cost of land and buildings thereon when purchased,

25. Cost of buildings used for offices, stables, \&c.,

- erected by the Company, or standing on land not owned by the Company, .

26. Cost of other articles of equipment, (specifying what,) .

27. Total cost of equipment, .

28. Amount included in the present and in past years in the running expenses for estimated or actual depreciation of any of the above items,

29. Net amount at which the equipment stands charged on the books of the Company, .

\section{Characteristics of the Road.}

30. Length of single main track,

31. Length of double main track,

32 .

Total length of road,

33. Length of branches owned by the Company, stating whether they have a single or double track,

34. Aggregate length of switches, sidings, turnouts, and other track, excepting main track and branches,

35. Total length of rail, :

36. Weight of rail used, per yard, (specifying whether of cast or rolled iron, ).

37. Maximum grade, per mile, on road, with length of grade,

38. Shortest radius of curvature, with length of curve,

39. Greatest length of single track on road between two turnouts,

40. Total length of main track which is paved,

\section{DoIngs dURING the Year.}

\section{(As returned by the Lessees.)}

41. Total number of miles run during the year,

42. Number of passengers carried in the cars,

43. Rate of speed adopted, including stops and detentions,

44. Rate of speed actually attained, including stops and detentions, .

None owned by the Company.

\section{$\$ 13,98554$}

- $\quad-$

The road being under lease, all the equipment, except the real estate, belongs to the lessees.

\section{2,594 feet. \\ 2,606 “ \\ 25,200 “}

13,524 feet of single track.

\section{2,420 feet.}

43,750 “

45 lbs. on main track, 33 lbs.

on branch. Rolled iron.

316.80 feet per mile, for 100

feet in length.

The curve at the foot of Summer Street, in Boston, is a compound curve, and, taken as a whole, has a radius of 122.15 feet, and is 111.02 feet long; the shortest radius of any 50 feet of it is 89.80 feet.

\section{3,383 feet.}

(The entire main track is - paved; the branch is un$\{$ paved, except at street or other crossings.

215,424 .

About 722,070.

\section{)}

About 7 miles per hour.

51, viz.: 12 conductors, 13 drivers, 9 shop hands, 14 stablers, 3 track-men. 
46. Total number of trips run during the year,

47. Average number of passengers each trip, .

\section{Expenditures for Working the Road.}

48. For repairs of road, including repairs of foundation, renewals of iron, and renewals of pavement, .

49. For general repairs, including repairs of cars, omnibuses and harnesses, and for shoeing horses,

50. For repairs of real estate, including repairs of buildings used as stables, offices, or for any other purposes, by the Company,

51. For wages, including the wages of every person regularly employed, excepting the president, directors, superintendent, and treasurer,

52. For interest,

53. For taxes and insurance,

54. For tolls paid other companies for the right to pass over their roads,

55. For rent paid other companies for use of their roads, .

56. For provender, - to include cost of hay, grain, straw, or other articles used for the food and bedding of horses.

57. For miscellaneous articles purchased during the year - such as harnesses, blankets, \&c., the use of which continues for one or more years - and not included in the cost of equipment, .

58. For loss on horses - that is to say, the difference between the present estimated value of the horses owned by the Company subtracted from the estimated value of those on hand at the commencement of the year, added to the cost of those purchased during the year; or if this is the first report of the Company, then the difference between the estimated value of the horses on hand and their cost-giving the present average estimated value of each horse,

59. For incidental expenses, - to include printing, president's, directors', treasurer's, and superintendent's salaries, and all expenses other than those belonging to the actual working of the road, .

60. For all other expenses

61. For amount charged on the Company's books during the year, for estimated or actual depreciation of the following property :-

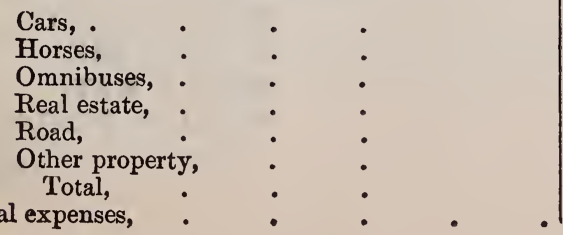

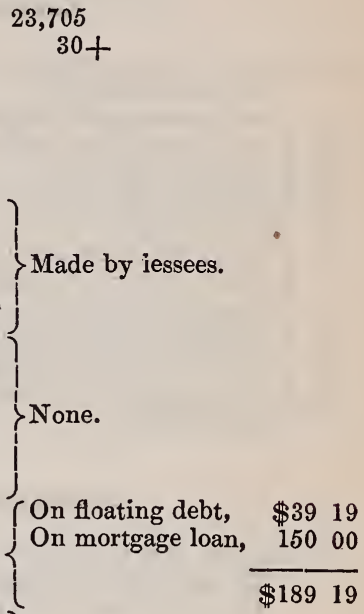




\section{EARNINGs.}

63. Received from passengers in cars and omnibuses, and for tickets sold,

64. From lessees, as toll or rent for use of road,

65. From United States mails,

66. For sales of manure,

67. From other sources,

68. Total earnings,

69. Net earnings, after deducting expenses, :

70. Surplus earnings of previous year, on hand,

71. Net earnings, as above,

72. Total surplus for payment of dividends, .

73. Dividends declared, during the year,

74. Total percentage of dividends, for the year,

75. Present surplus,

\section{Miscellaneous.}

76. Increase during the year -

Of capital stock, as fixed by the charter,

Of capital stock, as voted by the Company,

Of capital stock, paid in,

77. Increase of funded debt, during the year,

78. Increase of floating debt, during the year,

79. Decrease of funded debt, during the year,

80. Decrease of floating debt, during the year,

81. Increase of mortgage debt, during the year,

82. Decrease of mortgage debt, during the year,

83. Increase in cost of road, during the year, including amount charged for depreciation thereon,

84. Decrease in nominal cost of road, by amount charged for depreciation thereon,

85. Increase in cost of equipment, during the year, including amount charged for depreciation thereon, .

86. Decrease in cost of equipment, by sale of any portion thereof, or by amount charged for depreciation,

87. List of accidents on road during the year,

$\$$

$\$ 7,77 \overline{7} 11$

:

$-$

-

35726

7,17007

8 per cent.

$7,527 \quad 33$

$7,428 \quad 00$

$\$ 9933$

$\$ 10,10000$

5,10000

$-$

$628 \quad 69$

$-$

$5,0 \overline{0} 00$

$-$

10,11027

$\$ 7,777 \quad 11$

7,17007

(A boy, four years of age, was injured, but not seriously, in the foot; and a little girl, who had clambered upon the platform of a car while it was standing still, jumped off when it started, and her foot was sprained and bruised, but not severely. There was no permanent injury in either case.

EDWARD KING, W. R. CLARK, JOHN J. MAY, WILLIAM HENDRY, 


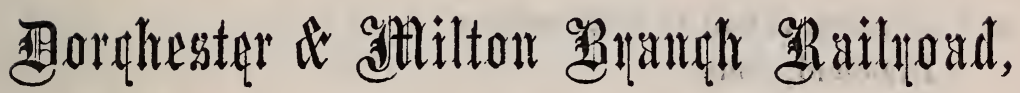

\section{FOR THE YEAR ENDING NOV. 30th, 1861.}

\section{REPORT.}

Reference is had to the report of last year, as containing answers to the several inquiries as to capital stock, shares, debt funded and floating, and rate of interest.

Also as to cost of road and equipment, amounting to the same sum as therein stated, to wit: $\$ 139,789.42$.

That report also contains statements as to the characteristics of the road, doings, expenditures, motive power, and cars, miscellaneous expenses, income dividends, mortgage debts, \&c., and is adopted as the annual return for the year 1861-no variation having been had in any material respect, except in the items of interest, and some inconsiderable variations in the ordinary expenses of repair and maintenauce. The variation from the report made last year being so small as to render any additional statement unnecessary.

Capital stock, - $\quad$ - $\quad$ - $\quad$ - $\$ 130,000.00$ No. of shares, 720.

Capital paid in per last report, - $\quad$ - $\quad 73,340.00$ Total capital paid in, - $\quad$ - $\quad 73,340.00$ Funded debt per last report, - $\quad$ - $\quad 36,900.00$ Floating debt per last report, - _ $\quad 11,355.73$

Present amount of funded and floating debt, 49,651.11 Maximum amount of debts during the year, $49,651.11$

Total cost of road, - $\quad$ - $\quad$ - $\quad$ - $\$ 136,789.42$ 
Characteristics of road same as in former returns.

The trains have been run by Old Colony and F. R. R. Co., and reference is had to their returns.

Dividend, none.

Mortgage debts per last report, _ _ - $\quad \$ 48,255.73$

Increase of Mortgage debts since last report,

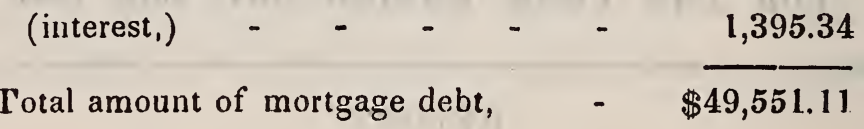

Number of mortgages on road and franchise, five.

NATH'L, F. SAFFORD,

E. P. TILESTON, Directors.

A. HOLILINGSWORTH, )

S. D. WHITNEY, Treasurer.

Suffulk, ss. December 26, 1861. Sworn to by said Amor Hollingsworth, E. P. Tileston, as true in substance, and according to the best of their knowledge and belief.

PE'IER C. JONES, Justice of the Peace.

Norfulk, ss. Jan. 1, 1862. Sworn to by Nath'l F. Safford, as true in substance, and according to his best knowledge and belief.

CHAS. ENDICOT'T, Justice of the Peace. 


\section{R E P 0 R T}

-

\section{Danvers Railroad Company,}

Report of the Danvers Railroad Corporation, for the year ending Nov. 30th, 1861, required by Chap. 63 of General Statutes.

Capital Stock ................. $\$ \$ 100,000.00$

Increase of capital since last Report ........

Capital paid in, per last Report.........65,580.00

Capital paid in, since last Report..........

Total amount of capital stock paid in ....

Number of shares of capital stock issued.....

Funded debt, per last Report............

Funded debt, paid since last Report........

Funded debt, increase of, since last Report...

Total present amount of funded debt......

Floating debt, per last Report............

Floating debt, paid since Report...........

Floating debt, increase of, since Report.....

Total present amount of fioating debt.....

Total present amount of funded and floating debt ......................

Maximum amount of debt during the year...

Average rate of interest per annum paid during the year $. . . . . . \ldots \ldots \ldots . .$.

\section{COST OF ROAD AND EQUIPMENT.}

For graduation and masonry, per last Report. $90,208.49$

For graduation and masonry, paid during the

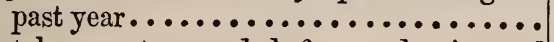

Total amount expended for graduation and masonry ....................

For wooden bridges, per last Report,.......

For wooden bridges, paid during past year,...

Total amount expended for wooden bridges,

Total amount expended for iron bridges, (if any) 
For superstructure, including fron, per last Re-

For superstructure, including iron, paid during the past year.................

Total amcunt expended for superstructure r including iron, ............... For stations, building and fixtures, per last report ...................

For stations, building and fixtures, paid cur$77,066.24$

ing the past year, ...............

Total amount expended for stations, buildings and fixtures...............

For land, land damages and fenees, per last report. ..................

For land, land clamages and fences, paid during the past year............... Total amount expended for land, lanci damages and fences, ...............

For locomotives, per last report .......... For locomotives, paid during past year...... Total amount expended for locomotives.... For passenger and baggage cars, per last re-

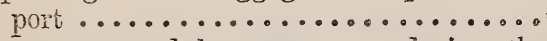

For passenger and baggage cars, during the past year, ..................

Total amount expended for passenger and baggage cars..................

For merchandise cars, per last report.......

For merchandise cars, paid during past year .

Total am't expended for merohandise cars .

For engineering per last report. .........

For engineering paid during the past year ...

Total amount expended for engineering ...

For agencies and other expenses, per last re-

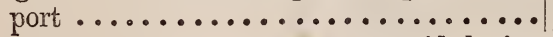
$2,615.00$ $30,821.58$

$77,066.24$ $9,374.17$

\section{$30,821.58$}

For agencies and other expenses, paid during

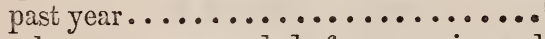

Total amount expended for agencies and other expenses .................

Total cost and equipment ........... Am't of assets or property held by the corporation in addition to the cost of the road. . CHARACTERISTICS OF ROAD.

Length of road................. Length of single main track........... 
Length of double main track...........

Length of branches owned by the company, stating whether they have a single or double track..................

Aggregate length of sidings, and other tracks, excepting main tracks and branches ....

Weight of rail, per yard, main road, ....... 1150 feet

Weight of rail, per yard, branch road....... Specify the different weights per yard....... Maximum grade, with its length, in main road 50 feet 6100 feet

Maximum grade, with length, in branch roads,

Total rise and fall in main road..........

Total rise and fall in branch roads.........

Shortest radius of curvature, with length of curve, in main road. .............

Shortest radius of curvature, with length of curve, in branch roads ...........

Total degrees of curvatuxe, in main road .... Total degrees of curvature, in branch roadis .. Total length of straight line, in main road ... Total length of straight line, in branches.... Agrregate length of wookien truss bridges ... Aggregate length of all other woorten bridges Aggregate length of iron bridges ......... Whole length of road unfensed on both sicles Number of public ways crossed at grade. .... Number of railroads crossed at grade ......

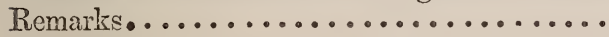
Way stations for express trains.......... Way stations for accommodation trains...... Flag stations ...................

Whole number of way stations..........

Whole number of fiag stations ..........

\section{MISCELIANEOUS.}

For salaries, office expenses, and all other expenses not inclnded in the foregoing itens.................................... 50.00

\section{1 degrees}

5 miles, 3900 feet

154 feet 
The road has been operated by the Boston \& Maine Railroad under their Lease, rent paid in advance in their guaranty of the notes of this Company-constituting the funded debt returned and the Directors refer to that corporation for report of the doings of the year

$$
\left.\begin{array}{l}
\text { GILBERT TAPLEY, } \\
\text { GEO. F. CHOATE, } \\
\text { WILLIAM D. NORTHEND, } \\
\text { CHARLES M. COX. }
\end{array}\right\} \begin{aligned}
& \text { Directors of the } \\
& \text { Danvers Railroad. }
\end{aligned}
$$

Essex, ss December 20th, 1861. Then personally appeared William D. Northend, Charles M. Cox and Gilbert Tapley and severally made oath to the truth, to the best of their knowledge and belief, of the foregoing statement by them subscribed.

Before,

GEO F. CHOATE, Justice of the Peace.

Essex, ss. Dec. 23d, 1861. Personally appeared Geo. F. Choate, and made oath that the foregoing report is true to the best of his knowledge and belief.

Before

JAMLES ROPES, Justice of the Peace. 


\section{R E P O R T}

OF THE

\section{I R E C T R S}

OF THE

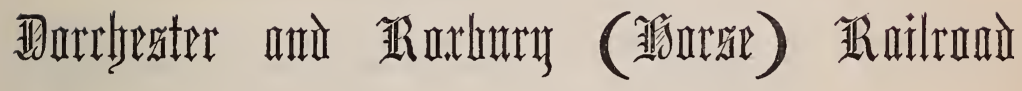

\section{COMPANY.}

FOR THE YEAR ENDING NOVEMBER 30, 1861.

\section{B O S T O N :}

WRIGHT \& POTTER, PRINTERS, 4 SPRING LANE.

1861 . 


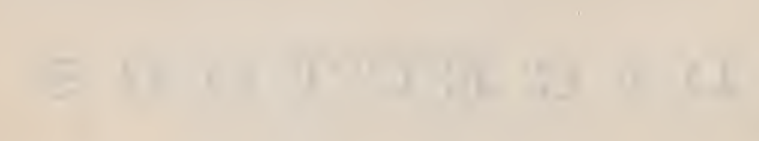

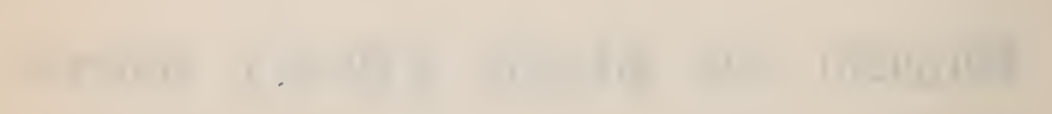




\section{REPORT OF THE DIRECTORS}

OF THE

\section{DORCHESTER \& ROXBURY (HORSE) R. R. CO.}

For the year ending November 30, 1861. General Statutes, Chap. 63, Sects. 143, 144.

\section{Condition of the Company.}

1. Capital Stock, fixed by Charter, .

$\$ 200,00000$

2. Capital Stock, as voted by the Company, . $\quad \$ 20,00000$

3. Capital Stock paid in, in cash, . . . 11,00000

4. Capital Stock paid in, in work and materials, by contractors and others,

5. Funded debt,

. $\quad . \quad . \quad$ None.

6. Floating debt, $• \quad \cdot \quad \cdot \quad \cdot \quad \cdot \quad 7,93167$

7. Total debt, . . . . .

8. Amount of above debt secured by mortgage of the road and franchise, or any property belonging to the corporation, or standing in its name,

9. Number of mortgages on road and franchise, or any property of the corporation, specifying the number and amount of mortgages on road and franchise, and each kind of property, .

10. Amount of assets on hand, exclusive of the road and equipment, and exclusive of all property on hand, used, or which is to be used, in running the road and keeping it in repair,.

\section{Cost of the Road.}

11. Amount expended for labor in excavating for the track, laying foundation and rails,

12. Amount expended for timber for foundation,

13. Amount expended for iron and other metal for rails, chairs, spikes, or other articles, used in building the road,

- None.

7,43700

[chester.

1,00000 Town of Dor-

6,437 00 To Directors.

7,93167

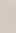

5,18321

\} 15138

14. Amount expended for paving, . . . .

15. Amount expended for paving stones, . . .

17. Amount expended for interest, salaries of officers during construction of road, and other expenses not included in any of the above items, which have been included, on the books of the company, in the cost of the road, not including items of equipment or running expenses, as

18.

Total below, - • • . among the running expenses for estimated or actual depreciation of the road, 


\section{Cost of Equipment.}

21. Number of ears and cost, .

22. Number of horses and cost,

23. Cost of omnibuses, sleighs and other vehicles, excepting cars, owned by the Company,

24. Cost of land and buildings thereon whien purchased,

25. Cost of buildings used for offices, stables, \&c., erected by the Company, or standing on land not owned by the Company,

26. Cost of other articles of equipment, (specifying what,) .

27. Total cost of equipment, :

28. Amount included in the present and in past years in the running expenses for estimated or actual depreciation of any of the above items,

29. Net amount at which the equipment stands charged on the books of the Company, .

\section{Characteristics of the Road.}

30. Length of single main track,

31. Length of double main track,

32. Total length of road,

33. Length of branches owned by the Company, stating whether they have a single or double track,

34. Aggregate length of switches, sidings, turnouts, and other track, excepting main track and branches,

35. Total length of rail, .

36 . Weight of rail used, per yard, (specifying whether of cast or rolled iron,) .

37. Maximum grade, per mile, on road, with length of grade,

38. Shortest radius of curvature, with length of curve,

39. Greatest length of single track on road between two turnouts,

40. Total length of main track which is paved,

$\$ 3,00000$

3,86896

,460 feet.

None.

7,460 feet.

None.

511 feet.

7,971 feet.

33 lbs. ; rolled.

173 feet per mile for $275 \mathrm{ft}$. 46 feet; length, 68 feet.

2,669 feet.

None.

The Road having been leased to the Metropolitan Railroad immediately on its completion, reference is made to their Report for the answers of all the following inquiries :-

\section{Doings duRing the Year.}

41. Total number of miles run during the year,

42. Number of passengers carried in the cars,

43. Rate of speed adopted, including stops and deten-

44. Rate of speed actually attained, including stops and detentions, .

45. Number of persons employed, regularly, (specifying the occupations of each,)

46. Total number of trips run during the year,

47. Average number of passengers each trip, . 
Expenditures for Working the Road.

48. For repairs of road, including repairs of foundation, renewals of iron, and renewals of pavement, .

49. For general repairs, including repairs of cars, omnibuses and harnesses, and for shoeing horses,

50. For repairs of real estate, including repairs of buildings used as stables, offices, or for any other purposes, by the Company,

51. For wages, including the wages of every person regularly employed, excepting the president, directors, superintendent, and treasurer,

52. For interest,

53. For taxes and insurance, .

54. For tolls paid other companies for the right to pass over their roads,

55. For rent paid other companies for use of their roads, .

56. For provender, - to include cost of hay, grain, straw, or other articles used for the food and bedding of horses.

57. For miscellaneous articles purchased during the year - such as harnesses, blankets, \&c., the use of which continues for one or more years - and not included in the cost of equipment, .

58. For loss on horses - that is to say, the difference between the present estimated value of the horses owned by the Company subtracted from the estimated value of those on hand at the commencement of the year, added to the cost of those purchased during the year; or if this is the first report of the Company, then the difference between the estimated value of the horses on hand and their cost - giving the present average estimated value of each horse,

59. For incidental expenses, - to include printing, president's, directors', treasurer's, and 'superintendent's salaries, and all expenses other than those belonging to the actual working of the road,

60. For all other expenses,

61. For amount charged on the Company's books during the year, for estimated or actual depreciation of the following property : -

\begin{tabular}{|c|c|}
\hline Cars, . & \\
\hline Horses, & • \\
\hline $\begin{array}{l}\text { Omnibuses, } \\
\text { Real estate, }\end{array}$ & • \\
\hline $\begin{array}{l}\text { Real estate, } \\
\text { Road, }\end{array}$ & \\
\hline Other propert & \\
\hline
\end{tabular}

62. Total,

$$
\$
$$

$$
:
$$

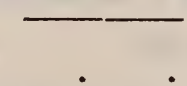

\section{Earnings.}

63. Received from passengers in cars and omnibuses, and for tickets sold,

64. From other roads, as toll or rent for use of road,

65. From United States mails, 
66. For sales of manure,

67. From other sources,

68. Total earnings,

69. Net earnings, after deducting expenses,

70. Surplus earnings of previous year, on hand,

71. Net earnings, as above,

72. Total surplus for payment of dividends, :

73. Dividends declared, during the year,

74. Total percentage of dividends, for the year,

75. Present surplus,

\section{Miscellaneous.}

76. Increase during the year -

Of capital stock, as fixed by the charter,

Of capital stock, as voted by the Company,

Of capital stock, paid in,

77. Increase of funded debt, during the year,

78. Increase of floating debt, during the year,

79. Decrease of funded debt, during the year,

80. Decrease of floating debt, during the year,

81. Increase of mortgage debt, during the year,

82. Decrease of mortgage debt, during the year,

83. Increase in cost of road, during the year, including amount charged for depreciation thereon,

84. Decrease in nominal cost of road, by amount charged for depreciation thereon,

85. Increase in cost of equipment, during the year, including amount charged for depreciation thereon, .

86. Decrease in cost of equipment, by sale of any portion thereof, or by amount charged for depreciation,

87. List of accidents on road during the year,

MARSHALL P. WILDER,

E. P. TILESTON,

WILLIAM D. SWAN,

SAMUEL GILBERT, JR.,

SAMUEL ATHERTON,

Directors of the Dorchester and Roxbury (Horse) Railroad Co.

Sufrolk, ss., December 21, 1861. Then personally appeared Marshall P. Wilder, E. P. Tileston, William D. Swan, Samuel Gilbert, Jr., and Samuel Atherton, and severally made oath to the truth of the foregoing statement, by them subscribed.

Before

EZRA FARNSWORTH, Justice of the Peace. 
THE

\section{A N NUALREPORT}

OF THE

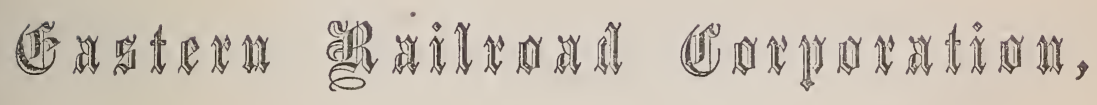

FOR THE YEAR ENDING

NOVEMBER 30,1861 .

S A L EM :

WM. IVES AND GEO. W. PEASE, PRINTERS.

1861. 



\title{
R E P O R T
}

\author{
OF THE DIRECTORS OF THE
}

\section{EASTERN RAILROADCORPORATION,}

\section{For the Year Ending November 30, 1861.}

To be returned to the Secretary of the Commonwealth, together with 1000 printed copies of the same, on or before the first Wednesday in January next.

[General Statutes, Chap. 63, Ssctions 132 to 105.

Capital Stock [being the whole amount authorized to issue, ] .

Number of shiares of capital stock issued,

Increase of Capital, since last heport, . . .

Capital paid in, per last Report, . . . .

Capital paid in, since last leport, . . .

Total smount of capital stock paid in, . . .

Funded debt, per last Report, . . . .

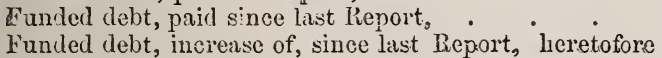
held as "property",

§Total present a mount of funded debt, : : :

Floating debt, per lasi Report, . . . .

Floating debt, paid since last Report. . . .

Floating debt, increase of, since last leport, .

Total present amount of floating debt, .

Total present amount of funded and foating debt,

Average rate of interest per annum, paid during the year,

Maximum amount of debts diring the year, .

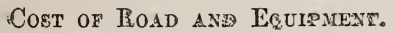

FFor graduation and masonry, per last Eeport,

For graduation and masonry, paid dering the past year

Total anount expended for graduation ars masonry,

For wooden bridges, per last Report

For wooden bridges, paid during the past year, .

Total amount expended for wooden bridges,

Total amount expended for iron bridges (if any)

For superstructure including iron, per last Report,

For superstructure, including iroks, paid during the past year,

Total amount expended for superstrecture, including iron,

For stations, buildings and fixtures, res last Report,

For stations, buildings and fixtures, paid during the past year,

Total amount expended for stations, buildings and fixtures,

Carried forward,

$$
\begin{aligned}
& 28,531 \\
& \text { IXone. } \\
& \$ 2,853,40000 \\
& 1,455,500 \quad \mathrm{C0} \\
& 75,00000 \\
& 4,59000
\end{aligned}
$$

$5 \frac{e 9}{100}$ per ct.

$2,705,50000$

748,15790

417,04581

748,15790

417,04581

$1,106,57303$

$542,267 \quad 74$

$1,106,57303$

$542,267 \quad 74$

$\$ 2,814,04448$

$\S$ We have also exchanged $\$ 8000$ for a like swm of Conway Railload Bonds, in protecting our interest therein. 
Brought forward,

For land, land damages and fences, per last Report,

For land, land damages and fences, paid during the past year,

Total amount expended for land, Iand-damages and: fences,

For locomotives, per last Report,

For locomotives, paid during the past year, .

Total amount expended for locomotives,

For passenger and baggnge cars, per last Rsport, .

For passenger and basgage cars, paid during the past jear,

Total amount expended for passenger and baggage ears

For mezchandise cars, por last Report,

For merchandise cars, paid during the prst jear,

Total amount expended for merchandise cars,

For enginecring, por lest Report, . . .

For engincering, paid during the past jear, .

Total amount expended fur engineeririg,

For ageneies and other expenses, per list Report,

For agencies amb other expenses lecreused during the past year,

Totnl anourit expended for agenoies and other cxpenses Total cost of roal and equipment,

Amount of assets or property held by the cormorition in adulition to lise cost of the roul,

702,35676

$\$ 2,814,01448$

53,20000

157,30000

53,20000

53,20000

101,66500

104,66500

$273,913 \quad 61$

278,91304

344,93721

$1 \pm 9,56702$

195,360227 $\overline{4}+300,81 \overline{1} \bar{\imath}$

437,55088

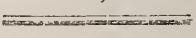

MaIN RoADl BRancres,

CIRAR:CTrmistres of ROAD.

Length of road, . . . . . Milcs.

Length of single min triak, . . Miles.

Length of double main tiack, . . Miles.

Longth of Mranches owned by the Compnny stat- S Single

ing whether they have a single or louble trask. $\}$ traik.

Aggregate length of sidingr, and other tracks, excepting main tiacks and branches,

Weight of rail, per yard, in main roar, Pounds.

Weight of rail, por Jard, in branch roads, (specify the different weights per yard)

Maximum grade, with its length, in main ? Iength road, \} 4640 iset.

Maximum grade, with its lengthe, in branch roads,

Total rise and fill in main road, .

Total rise and fill in braneh roads.

Shortest radius of curvature, with length of curve, in main road,

Shortest radius of curvature, with length of curve, in branch roads,

liadius $1140 \mathrm{ft}$.

. . Radius $1140^{\mathrm{ft}} \mathrm{f}$.

grees of curvature, in main road,

Total degrees of curvature, in branch roals, . .

Total length of straight line, in main road, . .

Total length of straight line in branches

Aggregate length of wooden truss bridges, . .

Aggregate length of all other wooden bridges, .

Aggregate length of iron bridges,

Whole length of raad unfenced on both sides,

Number of public ways crossed at grade,

Number of lailroads crossed at grade,

Remarks,

Way stations for express trains, .

Way stations for accommodation trains,

Flag stations,

Whole number of way stations,

Whole number of flag stations,

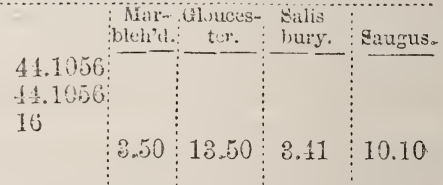

44.005 ft: $702 \mathrm{ft} 3139 \mathrm{ft} 902 \mathrm{ft} 1096 \mathrm{ft}$ $57,61,62:$

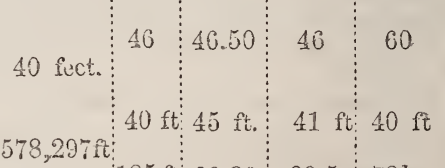

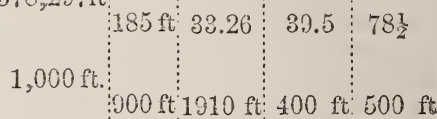

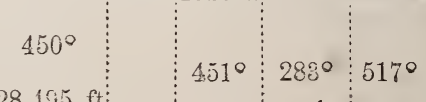

\begin{tabular}{ll|l|l|l}
28,495 & $\mathrm{ft}$ & & & \\
& 1,331 & 7,911 & 2,166 & 2,715
\end{tabular}

$2,218 \mathrm{ft}:$

$10,420 \mathrm{ft}: 165 \mathrm{ft} 420 \mathrm{ft} 106 \mathrm{ft} 665 \mathrm{ft}$ 


\section{Doings During the Year.}

Miles run by passenger trains, -

Miles run by freight trains,

Miles run by other trains,

iotal miles run,

Number of passengers carried in the cars,

Number of passenger's carried one mile,

Number of tons of merchandise carried in the cars,

Number of tons of merchandise carried one mile,

Number of passengers carried one mile, to and from other roads,

Number of tons carried one mile, to and from other roads,

Rate of speed adopted for express passenger trains, inclucting stops

Average rate of speed actually attained by express passenger trains, including stops and detentions,

Rate of speel arlopted for accommodation trains,

Ritre of specd actually attaineal by acconmodation triains, including stops and detentions,

Arorage rate of speed actually attainel by special trains, incluling stops and detcutions, -

Average rate of speci adopted for freight trains, incluting stops,

Estimated weight in tons of passenger cars (not includinr passengers) hanled one mile,

Lstimatod weight in tons of merehmilise cars (not including freight) hauled onc mile, -

\section{Expenditures for Workixg the Ro.ID.}

For repairs of road, maintenance of way, exclusire of wooden bridges, and reneivals of iron,

For repairs of wooden bridges,

For wages of switchmen, ar per nonth,

For wages of gntc-keepers, ar. per month, $\$ 20,00$

For wages of signal-men, av. per month, 435,00$\}$

For warges of watchmen, av. per month, $\$ 32,50$

Number of men employed, exolusive or those engaged in construction,

For remoring ice and snow, (this item to incluite all libor, tools, repairs, and extra steam-power used,)

For ropairs of fences, gates, houses for signal-men, gate-keepers, switchmen, tool-houses,

Tiotal for maintenance of way,

22 Miles per hour.

$2 \cdot 266 \quad 66 \quad 66$

$21 \quad 66 \quad 66 \quad 66$

$20 \quad 66 \quad 66 \quad 66$

$2266 \quad 66 \quad 66$

$12 \quad 66 \quad$ i6 6

$8,608,700$

$1,500,538$

$\$ 27,06279$

(3, 98910

13,13487

411

85887

30251

$\$ 51,20814$

\$29,517 21

$19,414 \quad 79$

10,18014

\section{Motive Power and Cars.}

For repairs of locomotives,

For new locomotives, to corer depreciation,

For repairs of passenger cars, - -

For new passenger cars, to cover depreciation, -

For repair's of merchandise cars, and other car's, -

For new merchanulise cars, to corer depreciation,

For repairs of gravel and other cars,

T'otal for maintenance of motive power and ears,

Number of engines,

Number of passenger cars, -

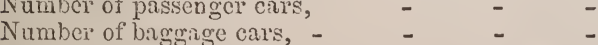

Stumber of merchandise cars, - -

Nuniber of gravel cars, - $\quad$ - $\quad$ - 


\section{Brought forward}

Misceltaneous.

For fuel used by engines during the year, viz. :-

1. Wood, number of cords, 1529 . Cost of the same,

2. Coal, number of tons, (reckoning 2,240 lbs. to the ton,) 5183. Cost of the same,

For oil used by cars and engines, gallons, 6,324, -

For waste and other material for cleaning,

For salaries, wages and incidental expenses, chargeable to passenger department,

For salaries, wages, and incidental expenses, chargeable to freight department,

For gratuities and damages, -

For taxes and insurance,

For ferries,

For repairs of station buildings, aqueducts, fixtures, furniture,

For renewals of iron, including laying down, and

For new iron laid down, deducting the value of old iron taken up,

For amount pail other companies, in tolls for passengers and freight carricd on their rouds, specifying each company,

For amount paid other companies, as rent for use of their roads, specifying eash company. (Grand Junction Railroad.) -

For salaries of president, treasurer, supcrintendent, law expenses, office expenses of the abore offices, and all other expenses not included in any of the foregoing items,

Total Miscellaneous,

Total expenditures for working the road,

Total amount of interest paid during the year.

\section{Income During the Iear.}

\section{For Passengers :-}

1. On main road, including branches owned by company, - 389,490 70

2. To and from other roacts, specifying

$$
\text { what. P. S. \& P. Roail - 41,670 } 99
$$

For Freight:-

1. On main road and branches owned by company,

2. To and from other connecting roads. U. S. Mails, P. S. \& P. Road,

Rents, -

Miscellaneous Total income,

Net earnings after deducting expenses, -

Interest

Surplus for the year

Profit and Loss Account -

Surplus last year

Total,

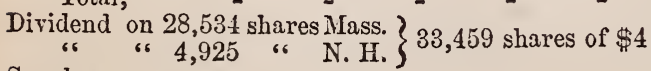

$\$ 110,41028$

6,87912

$30,417 \quad 58$

5,98355

1,22167

89,73660

$16,030 \Omega 8$

2,12379

9,118111

4,06340

29,12600

11,00000

$12,443 \quad 42$

$209,127 \quad 22$

219,58750

$491,161 \quad 69$

$100,106 \quad 85$

9,72400

$8,507 \quad 20$

16,34926

565,93900

$\$ 246,40150$

107,13923

16,15968

240,40728

$\$ 139,26227$

256,566 91

395,82918

$133,836 \quad 00$

Carried over - - $-261, \overline{99318}$ 
Amount brought over

From which has been Paid,

For Engines

"Bridges and wharf

“ Land bought at Beverly

Charged off from cost South Reading Road

\section{Surplus}

Estrmated Depreclation Beyond the Renewals, viz :

Of road and bridges,

Buildings,

Engines and cars,

\section{Mortgage Debts.}

Amount of debts secured by mortgage of road and franchise, or any property of the Corporation, per last Report,

Mortgage debt paid since last Report,

Increase of mortgage debt since last Report, -

Present amount of mortgage debts,

Number of mortgages on road and franchise, or any property of the corporation,

, per
-
-
- any

$\$ 261,99318$

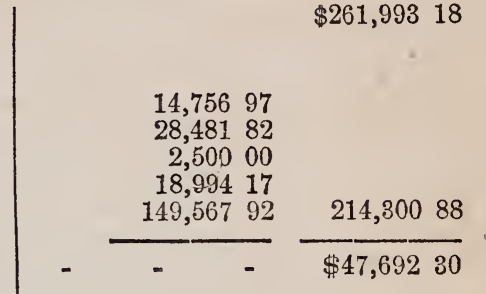

\section{GEORGE M. BROWNE, MICAJAH LUNT, F. HAVEN, \\ NATHAN D. CHASE, W. L. DWIGHT, HENRY L. WILLIAMS,}

$\$ 500,00000$

Nothing.

Nothing.

500,00000

One.

\section{Directors of the}

Eastern Railroad

Corporation.

SurfoLk, ss. December 19, 1861. Then personally appeared George M. Browne, Micajah Iunt, Nathan D. Chase, W. L. Dwight, Henry L. Williams, and F. Haven, and severally made oath to the truth of the foregoing statement by them subscribed, according to their best knowledge and belief, before me,

JOHN B. PARKER, Justice of the Peace. 


\section{A C C I DEN TS.}

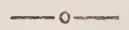

1860.

December 25. A sleigh being driven across the track, near the Salem depot, was struck by the train, and one of its occupants injured.

1861.

January 15. A man named Owens, walking on the track near Lynn, was struck by the train and somewhat injured.

March 2. A lad named Wilson fell under a passenger car at Marblehead, and was fatally injured.

March 15. Mr. White, walking on the track near Mystic River Bridge, was struck by the train and killed.

March 16. A boy in attempting to get upon the train, as it was entering the Beverly Depot, fell under the cars, and had one leg so much injured that amputation was necessary.

Narch 20. A boy named Shanghiney, was struck by a train as it was backing into Amesbury depot, and instantly killed.

May 20. J. C. Farley, (a lad) who was riding on the freight train, near Ipswich, jumped. from the train while in motion, and was fatally injured.

May 29. A passenger fell from the train near North Chelsea, and was killed.

July 5. Mr. Goldthwaite was struck by a freight train near West Beach station, and so much injured that he died a few days afterwards. 


\section{EIGHTH ANNUAL REPORT}

OF THE DIRECTORS OF THE

\section{Easton Branch Railroad Company.}

Return of the Easton Branch Railroad Corporation, for the yeur ending Nov. 30, 1861, under the Acts of 1849, Chap. 191; 1851, Chap. 102; 1854, Chap. 423; 1856, Chap. $165 ; 1857$, Chapters 40, 168, and $240 ; 1858$, Chap. 46.

\section{Capital Stock,}

Number of shares of capital stock issued, :

Increase of capital since last Report,

Capital paid in, per last Report,

Capital paid in since last Report

Total amount of capital stock paid in.

Funded debt, per last Report, .

Funded debt paid since last Report, .

Funded debt, increase of, since last Report,

Total present amount of Funded debt,

Floating debt, per last Report,

Floating debt, paid since last Report,

Floating debt, increase of, since last Report,

Total present amount of floating debt,

Total present amount of funded and floating debt,

Average rate of interest per annum, paid, during the year, .

Maximum amount of debts during the year :

\section{Cost of Road and Equipment.}

For graduation and masonry, per last Report.

For graduation and masonry, paid during the past year,

Total am't expended for graduation and masonry,

For wooden bridges, per last Report,

For wooden bridges, paid during the past year, .

Total amount expended for wooden bridges, :

Total amount expended for iron bridges, (if any,

For superstructure, including iron, per last Report,

For superstructure, including iron, paid during the past year,

Total amount expended for superstructure, including iron,

For stations, buildings and fixtures, per last Report, .

For stations, buildings and fixtures, paid during the past year, .

Total amount expended for stations, buildings and fixtures,

For land, land-damages and fences, per last Report,

For land, land damages and fences, paid during the past year,

Total amount expended for land, land-damages and fences,
$\$ 50,00000$

490.

None.

$\$ 49,32500$

None.

None

None.

None.

None.

$\$ 2,80000$.

None.

None.

2,80000

Six per cent.

$\$ 2,80000$.

$\$ 15,54126$.

Nothing.

Nothing.

Nothing.

Nothing.

Nothing.

$\$ 24,41683$.

Nothing.

$\$ 7,10148$

24,41683

Nothing.

$\$ 754725$.

7,10148

Nothing. 
For locomotives, per last Report

For locomotives, paid during the past year,

Total amount expended for locomotives,

For passenger and baggage cars, per last Report,

For passenger and baggage cars, paid during the past year,

Total amount expended for passenger and baggage cars,

For merchandise cars, per last Report, :

For merchandise cars, paid during the past year,

Total amount expended for merchandise cars,

For engineering, per last Report,

For encineering, paid during the past year,

Total amount expended for engineering, .

For agencies and other expenses, per last Report,

For agencies and other expenses, paid during the past year,

Total amount expended for agencies and other expenses

Total cost of road and equipment,

Amount of assets or property held by the corporation in addition to the cost of the road.

\section{Characteristics of Roan.}

Length of road,

Length of single main track,

Length of clouble main track, .

Length of branches owned by the company, stating whether thcy have a single or double track,

Aggregate length of sidings, and other tracks, excepting main track and branches,

Weight of rail, per yard, in main road, . . .

Weight of rail, per yard, in branch roads, (specify the different weights per yard,)

Maximum grade, with its length, in main road, .

Maximum grade, with its length, in branch roads,

Total rise and fall in main road,

Total rise and fall in branch roads, . . . .

Shortest radius of curvature, with length of curve, in main road,

Shortest radius of curvature, with length of curve, in branch roads,

Total degrees of curvature, in main road,

Total degrees of curvature, in branch roads,

Total length of straight line, in main road,

Total length of straight line in branches,

Aggregate length of wooden truss bridges,

Aggregate length of all other wooden bridges,

Aggregate length of iron bridges,

Whole length of road unfenced on both sides,

Number of public ways crossed at grade, .

Number of railroads crossed at grade,

Remarks,

Way stations for express trains,

Way stations for accommodation trains,

Flag stations,

Whole number of way stations,

Whole number of flag stations,

\author{
Owned and run \\ by \\ Providence R. R. Co. \\ $\$ 1,28745$. \\ Nothing.
}

Nothing.

$\$ 1,28745$

Nothing.

Nothing.

$3 \frac{3}{4}$ miles, 177 feet.

$3 \frac{3}{4}$ milus, 177 feet.

None.

None.

56 lbs.

None.

72 6-10 feet for $3400 \mathrm{ft}$

None.

118 feet.

None.

716 feet for 447 feet.

None.

$205^{\circ}$

None.

$1 \frac{3}{4}$ miles, 886 feet.

None.

None.

None.

None.

None.

Three.

None.

None.

None.

One.

None.

One. 


\section{DOINGS DURING THE YEAR.}

Miles run by passenger trains,

Miles run by freight trains.

Miles run by other trains,

$$
\text { Total miles run, }
$$

Number of passengers carried in the cars,

Number of passengers carried one mile, . . .

Number of tons of merchandise carried in the cars,

Number of tons of merchandise carried one mile,

Number of passengers carried one mile, to and from other roads,

Number of tons carried one mile, to and from other roads, .

Rate of speed adopted for express passenger trains including stops, .

Average rate of speed actually attained by express passenger trains, including stops and detentions, .

Rate of speed adopted for accommodation trains,

Rate of speed actually attained by accommodation trains, including stops and detentions,

Average rate of speed actually attained by special trains, including stops and detentions

Average rate of speed adcpted for freight trains, including stops,

Estimated weight in tons of passenger cars, (not including passengers, ) hauled one mile,

Estimated weight in tons of merchandise cars, (not including freight,) hauled one mile,

\section{Expenditures for Working the Road.}

For repairs of road, maintenance of way, exclusive of wooden bridges, and renewals of iron,

For repairs of wooden bridges,

For wages of switchmen, average per month, \$

For wages of gate-keepers, average per month, \$

For wages of signal-men, average per month, $\$$

For wages of watchmen, average per month, $\$$

Number of men employed, exclusive of those engaged in construction,

For removing ice and snow, (this item to include all labor, tools, repairs, and extra steam-power used,) .

For repairs of fences, gates, houses for signal-men, gate-keepers, switchmen, tool-houses,

Total for maintenance of way,

\section{Motive Power and Cars.}

For repairs of locomotives,

For new locomotives, to cover depreciation,

For repairs of passenger cars, .

For new passenger cars, to cover depreciation,

For repairs of merchandise cars,

For new merchandise cars, to cover depreciation,

For repairs of gravel and other cars,

Total for maintenance of motive power and cars,

Number of engines,

Number of passenger cars, $\quad \cdot \quad \cdot \quad \cdot \quad \cdot \quad \cdot \quad$ :

Number of baggage cars, $\quad \cdot \quad \cdot \quad \cdot \quad \cdot \quad \cdot$

Number of merchandise cars, . $\quad . \quad \cdot \quad \cdot \quad$.

4695 .

2347 .

16,606 .

66,424 .

7,661 .

30,644 .

53,436 .

28,855 .

No express trains. 30 miles per hour.

30 miles per hour.

30 miles per hour.

46,950 .

52,672 .

\section{$\$ 79287$.}

Nothing.

Nothing*

Three.

Nothing.

$\$ 79287$

Locomotives and freight cars furnished by Boston \& Proridence Railroad Co.

Passenger cars furnished by the Stoughton Branch Railroad Co. 


\section{Miscellaneous.}

For fuel used by engines during the year, viz :-

Wood, number of cords, Cost of the same, .

Coal, number of tons, (reckoning 2,240 lbs. to the ton,) Cost of same,

For oil used by cars and engines,

For waste and other material for cleaning,

For salaries, wages and incidental expenses, chargeable to passenger department,

For salaries, wages and incidental expenses, chargeable

to freight department,

For gratuities and damages, .

For taxes and insurance,

For ferries,

For repairs of station buildings, aqueducts, fixtures, furniture,

For renewals of iron, including laying down, .

For new iron laid down deducting the value of old iron taken up,

For amount paid other companies, in tolls for passengers and freight carried on their roads, specifying each company,

For amount paid other companies, as rent for use of their roads, specifying each Co.

For salaries of president, treasurer, superintendent, law expenses, office expenses of the above offices, and all other expenses not included in any of the foregoing items,

Total Miscellaneous, . . .

Total expenditures for working the road, .

Total amount of interest paid during the year,

\section{INCOME DURING THE YeAR.}

\section{For Passengers :}

1. On main road, including branches owned by comp'y

2. To and from other roads, specifying what,

For Freight:-

1. On main road and branches owned by company,

2. To and from other connecting roads,

U. S. Mails,

Rents,

Total income,

Net earnings, after deducting expenses,

\section{- Dividends.}

Three per cent. Total, .

Surplus not divided,

Surplus last year, .

Total surplus,

Estimated Depreciation beyond the Renewals, VIZ :

Of road and bridges,

Buildings,

Engines and Cars,

\author{
Operated by \\ Boston \& Prov.R.R.Co. \\ $\$ 1093$. \\ Nothing. \\ Nothing. \\ Nothing. \\ Nothing.
}

$\$ 89479$ to Boston and Providence R. R. Co.

$\$ 11738$ to the Stoughton Branch R. R. Co.

$\$ 56820$.

$\$ 1,59130$

$2,384 \quad 17$

16800

$\$ 26611$.

2,88305 .

6342.

2,04059 .

14574 .

5,39891

2,84674

1,34674 .

15,00000

46592 .

1,81266

None.

None,

None. 


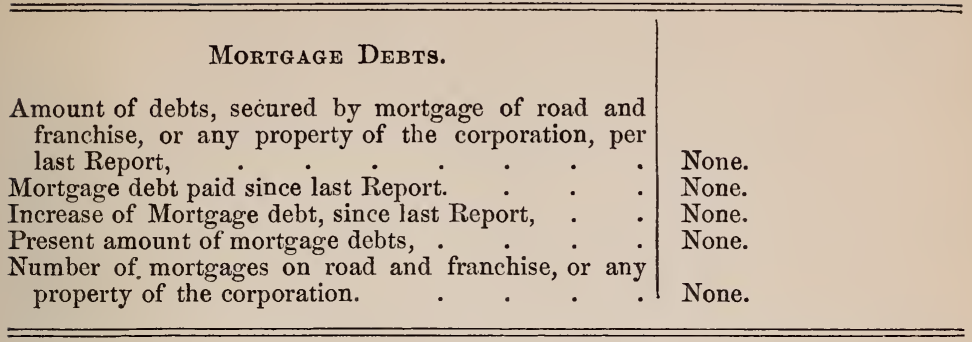
$\left.\begin{array}{l}\text { OAKES AMES, } \\ \text { OLIVER AMES, JR., } \\ \begin{array}{l}\text { A. A. GILMORE, } \\ \text { CYRUS LOTHROP, }\end{array}\end{array}\right\}$ Directors.

Bristol, ss., December 18, 1861.

Then personally appeared Oakes Ames, Oliver Ames, Jr., A. A. Gilmore and Cyrus Lothrop and severally made oath to the truth of the foregoing statement by them subscribed.

Before

JOHN H. SWAIN, Justice of the Peace. 




\title{
ANNUAL REPORT
}

\author{
OF THE
}

\section{ESSEI RAII ROAD;}

\section{FOR THE YEAR RNDING}

NOVEMBER 30,1861 .

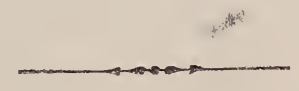

S A L $\mathrm{EM}$ :

WR. IVES AND GEO. W. PEASE....PRITTERS,

$$
1861 .
$$





\title{
REPORT
}

\author{
OF TIE DIRECTORS OF THE
}

\section{ESEX RAILPOAD CORPORATION,}

\section{For the Year Ending November 30, 1861.}

To be returned to the Secretary of the Commonwealth, together with 1000 printed copies of tho same, on or before the first Wednesday in January next.

[General Staitutes, Chap. 63, Sections 132 to 135.

Capital Stock,

Number of shares of capital stock issued, .

Increase of Capital, since last Report, . . .

Capital paid in, per last Report, . . . .

Capital prid in, since last lieport, . . .

'Total amount of capital stock paid in, . . .

Funded debt, per last Report, . . . .

Funded debt, paid since last Report, . . .

Funded debt, increase of, since last Report, .

Total present amount of funded debt, . . .

Floating debt, per last Report, . . . .

Floating debt, paid since last Report, . . .

Floating debt, increase of, since last Report, .

Total present amount of floating debt, . . . .

Total present amount of funded and floating debt,

Average rate of interest per annum, paid during the year, . . . . .

Maximum amount of debts during the year,

\section{Cost of Rond and ECUIPMEnt.}

For graduation and masonry, per last Report,

For gaduation and masonly, paid during the past year

Total wount expended for graduation and masonry,

For wow de $\eta$ bridges, per last Report, .

For woodtn bridges, paid during the past year, .

Total amourt expended for wooden bridges,

Total amouut expended for iron bridges (if any)

For superst ycture including iron, per last Report,

For superstructure, including iron, paid during the past y $\approx a r$,

Total amou at expended for superstrusture, including iron,

For stations, buildings and fixtures, per last Report,

For stations, buildings and fixtures, paid during the past year,

Total amount expended for stations, buildings and fixtures,

Carried forward,
$\$ 700,00000$

$\$ 299,10755$

280,26139

299,10755

280,26139

197,42802

$197,428 \quad 02$

$47 \overline{7,6894}$

Six per cent.

211,73218

32,37444

211,73218

$32,374 \quad 44$

190,25206

$\overline{20,78349}$

190,25206

20,783 หิ9 
Brought forward,

For land, land dimages and fences, per last Report,

For land, land damages and fences, paid during the past year,

Total amount expended for land, land-damages and fences,

For locomotives, per last Report, ${ }^{\circ} \quad \dot{0}^{\circ}$.

For locomotives, paid during the past year,

Total amount expended for locomotives, . .

For passenger and baggage cars, per last Poport, .

For passenger \& baggage cars, paid during the past year

Total amount expended for passenger and baggage cars

For merchandise cars, per last Report,

For merchandise cars, paid during the past year,

Total amount expended for merchandise cars,

For engineering, per last Report, . . .

For engineering, paid during the past year, .

l'otal amount expended for engineering,

For agencies and other expenses, per last Report,

For agencies and other expenses paid during the past year,

motal amount expended for agencies and other expenses

Total cost of road and equipment,

Amount of assets or property held by the corporation in addition to the cost of the road,

CHARACTERISTTCS OF ROAD.

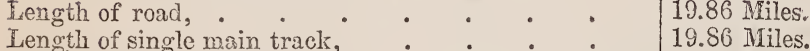

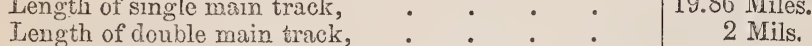

Length of branches owned by the Company stat- Single

ing whether they have a single or double track. $\}$ track.

Aggregate length of sidings, and other tracks, excepting main tracks and branches,

Weight of rail, per yard, in main road,

Weight of rail, per yard, in branch roads, (specify the different weights per yard)

Naximum grade, with its length in main road, :

Maximum grade, with its length, in branch roads,

Total rise and fall in main road, .

Total rise and fall in branch roads. $\quad$ : :

Shortest radius of curvature, with length of curve, in main road,

Shortest radius of curvature, with length of curve, in branch roads,

Total degrees of curvature, in main road, ?

Total degrees of curvature, in branch roads, .

Total length of straight line, in main road, . .

Total length of straight line in branches

Aggregate length of wooden truss bridges, :

Aggregate length of all other wooden bridges, .

Aggregate length of iron bridges,

Whole length of road unfenced on both sides, .

Number of public ways crossed at grade ${ }_{9}$.

Number of railroads crossed at grade, . .

Remarks,

Way stations for express trains,

Way stations for accommodation trains, $\quad: \quad 10$

Flag stations, . . . . . . . . 5

Whole number of way stations, : $\quad \cdot \quad \cdot \quad \cdot \quad-10$

\subsection{Miles.}

10,190 feet.

56 and 60 lbs.

25 ft. $18.810 \mathrm{ft}$. Length.

$249 \frac{1}{2}$ feet

866

Badius $477 \frac{7}{2}$ feet. 900 feet.

66 446 "6 200 66
$839937^{\prime}$
1569 .
14.6 Miles.
1.3 "6
40 feet.
3723 feet.
29
2
10
5
10
5




\section{DoINGS DURING the Year.}

Miles run by passenger trains, - _ _ _ $\quad 40,260$

Miles run by fireight trains, - $\quad$ - $\quad$ -

Miles run by other trains, - $\quad$ - $\quad$ -

18,075

Total miles run, - - _ - $\quad$ -

66,095

601,390

35,035

661,600

Number of passengers carried one mile, - -

Number of tons of merchandise carried one mile,

Number of passengers carried one mile, to and from other roads,

Number of tons carried one mile, to and from other

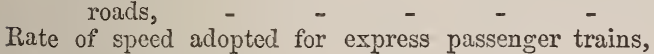
including stops

Average rate of speed actually attained by express passenger trains, including stops and detentions,

Rate of speed adopted for accommoclation trains,

Rate of speed actually attained by accommodation trains, including stops and detentions,

Average rate of speed actually attained by special trains, including stops and detentions,

Average rate of speed adopted for freight trains, including stops,

Estimated weight in tons of passenger cars (not including passengers) hauled one mile,

Estimated weight in tons of merchandise cars (not including freight) hauled one mile, - -

\section{Expenditures ror Working the RoAD.}

For repairs of road, maintenance of way, exclusive of wooden bridges, and renewals of iron,

For repairs of wooden bridges,

For wages of switchmen, av per month,

For wages of gate-keepers, av. per month,

For wages of signal-men, av. per month,

For wages of watchmen, av. per month,

Number of men employed, exclusive of those engaged in construction,

For removing ice and snow, (this item to include all labor, tools, repairs, and extra steam-power used,)

For repairs of fences, gates, houses for signal-men, gate-keepers, switehmen, tool-houses, Iotal for maintenance of way,

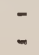

139,095

21 Miles per hour.

20 6 6 6

21 "6 "6

20 66 66 66

$12 \quad 66 \quad 66 \quad 66$

120,270

463,120

$\$ 12,08779$

\section{Motive Power and Cars.}

For repairs of locomotives,

For new locomotives, to cover depreciation,

For repairs of passenger and freight cars,

For new passenger cars, to eover depreciation,

For repairs of merchandise cars,

For new merchandise cars, to cover depreciation,

For repairs of gravel and other cars,

Total for maintenance of motive power and cars,

Number of engines,

Number of passenger cars,

Number of baggage cars, -

Number of merchandise cars,

Number of gravel cars,

Carried forward,

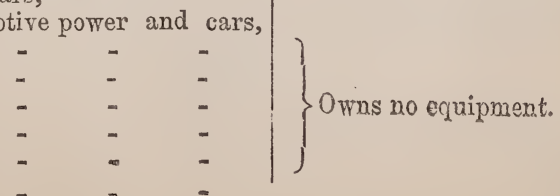

3,80453

4,38788

12,08779

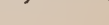


Brought forward,

Miscellaneous.

For fucl used by engines during the year, viz. :-

1. Wood, number of cords, 140 . Cest of the same,

2. Coal, number of tons, (reckoning 2;240 lbs. to the ton,) 790 . Cost of the same,

62535

4,57875

$8795 \pm$

For oil used by cars and engines, gallons, 931, -

For waste and other material for cleaning,

For salaries, wages and incidental expenses, chargeable to passenger department,

For salaries, wages, and incidental expenses, chargeable to fieight department, -

For gratuities and damages, - $\quad$ -

For taxes and insurance

For ferries,

For repairs of station buildings, aqueducts, fixtures, furniture, and other station expenses,

5,26333

3,68192

.4000

7749

5,25680

For renewals of iron, including laying down,

For new iron laid down, decheting the value of old iron taken up,

For amount paid other companies, in tells for passengers and fieight carried on their roads, specifying each company,

For amount paid other companies, as rent for use of their roads, specifying cach company, (Boston and Maine Ravil Road.)

For office expenses,

Total Miscellaneous, - $\quad$ -

Total expenditures for working the road,

Total amount of interest paid during the year.

\section{Incone During tae TelR.}

\section{For Passengers :-}

1. On main road, including branches owned by ?

2. To and from otiner rouds, specifying what - -$\}$

1. On main road and branches owned. by company, - - 25,307 56

2. To and from other connecting roads. $\quad .4,39883$

U. S. Mails,

Rients- -

Total income,

s,

$29,706 \quad 39$

46200

$8,688 \cdot 2$

56,06035

Net earnings after declueting expenses,

$10,187 \quad 69$

Interest paid in Bonded Debt - _ _

15,36641

“ due Eastern Railroad - _ _ _ $\quad 15,84614$

$31,212 \quad 55$

$\$ 21,02488$

Per cent

Surplus not divided,

Surplus last year -

Total surplus, 
Estimated Depreciation Buyond the Renewals, viz.

Of road and bridges,

Buildings,

Engines and cars,

\section{Mortgage Debts.}

Amount of debts secured by mortgange of road and franchise, or any property of the Corporation, per last Report,

Mortgage debt paid since last Report, Increase of mortgage debt since last Report, Present amount of mortgage debts,

Number of mortgages on road and franchise, or any property of the corporation, -

DAVID PINGREE, N. WESTON, STEPHEN A. CHASE, J. N. SAUNDERSON,
Directors of the Essex Railroad Corporation.

Essex, ss. December 27, 1861. Then personally appeared David Pingree, Nathaniel Weston, and J. N. Saunderson, and sererally made oath, and Stephen A. Chase made affirmation, that the foregoing statement by them subscribed is true, according to their best knowledge and belief. Before me,

MARK HASIKELL, Justice of the Peace. 



\section{R E P O R T}

Or THE

\section{FITCHBURG RAILROAD}

\section{CORPORATION.}

FOR THE YEAR ENDING NOVEMBE $30,1861$.

B O S T O N :

1861. 



\title{
R E P O R T
}

OF THE

\section{FITOII URRG IRAIROAD}

\author{
C O R P O R A T I O N.
}

Report of the Directors of the Fitchburg Railroad Corporation for the year ending November 30, 1861.

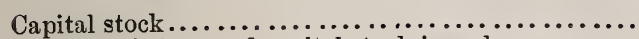

Number of shares of capital stock issued, ..........

Increase of capital, since last report,............

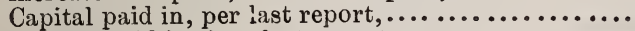

Capital paid in since last report,...............

'Iotal amount of capital stock paid in,.........

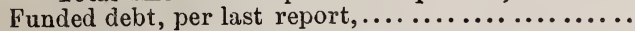

Funded debt, paid since last report, ............

Funded debt, increase of, since last report,........

Total present amount of funded debt,..........

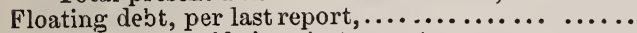

Floating debt, paid since last report,............

Floating debt, increase of, since last report, ........

Total present amount of floating debt, ............ Total present amount of funded and floating debt,... Average rate of interest per annum, paid during the

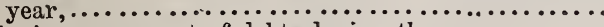

Maximum amount of debts during the year,.......

\section{Cost of Road and Equipment.}

For graduation and masonry, per last report,...... For graduation and masonry, paid during the, past

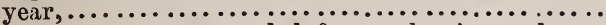

Total amount expended for graduation and ma-

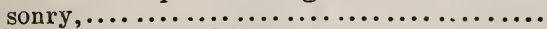

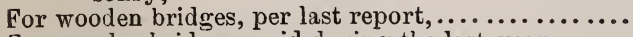
For wooden bridges, paid during the last year, ......

Total amount expended for wooden turidges, ... Total amount expended for iron bridges (if any,).... For superstructure, including iron, per last report,...
$\$ 3,540,00000$

35,400

None.

$3,540,00000$

None.

\}

$\$ 3,540,00000$

This Corporation has no debt

$\$ 757,69616$

None.

300,00000

$\$ 757,696 \quad 16$

None.

None.

300,00000

905,00000 
For superstructure, including iron, paid during the past year,...............................

Total amount expended for superstructure, including

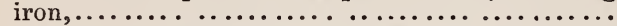

For stations, buildings and fixtures, per last report, for stations, buildings and fixtures paid during the past year,........................... Total amount expended for stations, buildings and

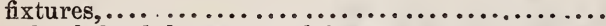
For land, land-damages and fences, per last report, For land, land-damages and fences, during the past

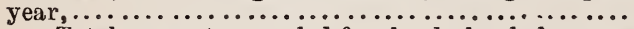

Total amount expended for land, land damages

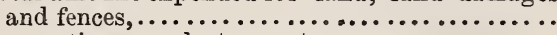

For locomotives, per last report, ..................

For locomotives, paid during the past year,..........

Tutal amount expended for locomotives, ..............

For passenger and baggage cars, per last report,....

For passenger and baggage cars, paid during the

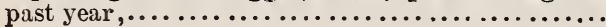
Total amount expended for passenger and bag-

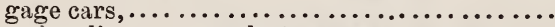
For merchandise cars, per last report, ...............

Fur merchandise cars, paid during the past year,.... Total amount expended fur merchandise cars,....

For engineering, per last report,$\ldots \ldots \ldots \ldots \ldots \ldots \ldots$

For engineering, paid during the past year, ..........

Total amount expended for engineering, ........

For agencies and other expenses, per last report.....

For agencies and other expenses paid during the past

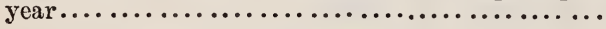

Total cost of road and equipment,........... Amount of assets or property held by the corporation in addition to the cost of the road,............

\section{Characteristics of Road.}

Length of road,$\ldots \ldots \ldots \ldots \ldots \ldots \ldots \ldots \ldots \ldots . .$.

Length of single main track,..................

Length of double main track,.$\ldots \ldots \ldots \ldots \ldots \ldots \ldots$.

Length of branches owned by the company, stating whether they have a single or double track,.......

Aggregate length of sidings, and other tracks, excepting main track and branches,..$\ldots \ldots \ldots \ldots \ldots$.

Weight of rail, per yard, in main road,................

Weight of rail, per yard, in branch roads, (specify the different weights, per yard, )................ Maximum grade, with its length, in main road,...... Maximum grade, with its length, in branch roads,... Total rise and fall in main road, $. . . \ldots \ldots \ldots . . . . . .$. Total rise and fall in branch roads, .................

Shortest radius of curvature, with length of curve, in main road, ................................

Shortest radius of curvature, with length of curve, in branch roads,.............................. Total degrees of curvature, in main road,............ Total degrees of curvature, in branch roads, ......... Total length of straight line, in main road,........... Total length of straight line, in branches, ............. Aggregate length of wooden truss bridges,........... Aggregate length of all other wooden bridges,......... Aggregate length of iron bridges,..............

None.

445,00000

905,00000

None.

732,96627

445,00000

None.

None.

$$
150,00000
$$

150,00000

31,00000

None.

None.

169,14932

31,00000

169,14932

None.

$$
49,18825
$$

None.

None.

$\$ 3,540,00000$

263,90095

5) and 93-100 mil

None.

50 93-100 miles.

30 93-100 miles. single track

22 63-100 miles

56 to 63 pounds.

$49,50,53,56$.

46 feet 5 12-100 miles long.

50 feet, 5190 feet long.

$739 \frac{1}{2}$ feet in 312 feet fall.

484 feet.

\}

\} 818 feet, 500 feet long.

38.5 feet, 530 feet long.

$1694 \frac{1}{2}$.

$1879 \frac{1}{3}$

$3467-100$ miles.

$205 \%-100$ miles.

1406 feet.

5990 feet.

None. 
Whole length of road unfenced on both sides,........ Number of public ways crossed at grade,.......... Number of railroads crossed at grade,............. Remarks, .............................. Way stations for express trains, ............... Way stations for accommodation trains,...........

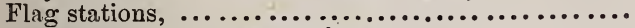
Whole number of way stations, ................ Whole number of flag stations, ................

\section{Doings during the Year.}

Miles run by passenger trains, ................

Miles run by freight trains, .................

Miles run by other trains, $\ldots \ldots \ldots \ldots \ldots \ldots \ldots \ldots \ldots \ldots$

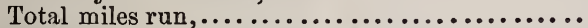

Number of passengers carried in the cars, ..........

Number of passengers carried one mile,............

Number of tons of merchandise carried in the cars,...

Number of tons of merchandise carried one mile,....

Number of passengers carried one mile, to and from

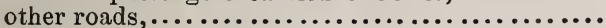

Number of tons carried one mile, to and from other

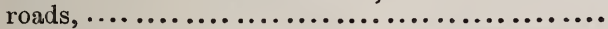

Rate of speed adopted for express passenger trains,

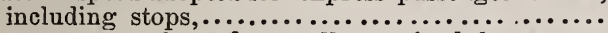

Average rate of speed actually attained by express passenger trains, including stops and detentions,...

Rate of speed adopted for accommodation trains,....

Rate of speed actually attained by accommodation trains, including stops and detentions, ...........

Average rate of speed actually attained by special trains, including stops and detentions,...........

Average rate of speed adopted for freight trains, in-

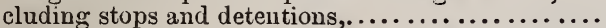

Estimated weight in tons of passenger cars, (not including passengers,) hauled one mile,...........

Estimated weight in tons of merchandise cars, (not including freight, ) hanled one mile,.............

\section{Expenditures tor Working the Road.}

For repairs of road, maintenance of way, exclusive of wooden bridges, and renewals of iron,..........

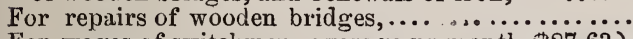

For wages of switclimen, average pr month, $\$ 27,63$

For wages of gate-keepers, average pr month, 19,21

For wages of signal-men, average pr month, 35,00

For wages of watchmen, average pr month, 30,64

Number of men employed, exclusive of those engaged

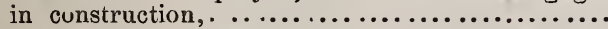

For removing ice and snow, (this item to include all labor, tools. repairs, and extra steam-power used,) For repairs of fences, gates, houses for signal-men, gate-keepers, switchmen, tool-houses,............

Total for maintenance of way,.................

\section{Motive Power and Cars.}

For repairs of locomotives, ................. For new locomotives, to cover depreciation, ........

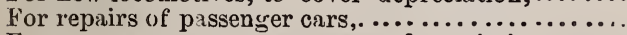
For new passenger cars, to cover depreciation, .......

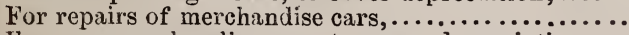
For new merchandise cars, to cover depreciation,... For repairs of gravel and other cars,............
None.

116 on main road and branches 5

None.

9

15

13 on main road and branches.

30

189,790

152,306

7.188

688,157

$10,420,495$

$32 \div, 500$

$7,789,515$

$3,139,978$

$5,281,883$

None run.

None run.

21 miles per hour.

21 miles per hour.

17 miles per hour

10 miles per hour.

$5,210,247$

$13,445,680$

$\left\{\begin{array}{c}61,47249 \\ 7,15372 \\ 10,27793\end{array}\right.$

348 men.

4,504 82

3,75556

87,16452

32,63561

None.

7,39863

None.

13,57267

3,55989

2438

349,284 
Total for maintenance of motive power and cars,

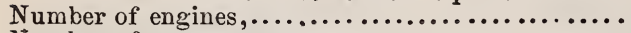
Number of passenger cars, $. \ldots \ldots \ldots \ldots \ldots \ldots \ldots . . . .$.

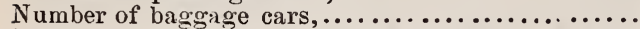
Number of merchandise cars, 2468 wheel, 34 wheel Number of gravel cars, .....................

\section{Miscellaneous.}

For fuel used by engines, during the year, viz.,..... 1. Wood, number of cords, 2130 . Cost of the

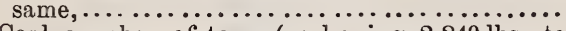
2. Coal, number of tons, (reckoning 2,240 lbs. to

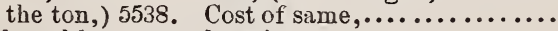

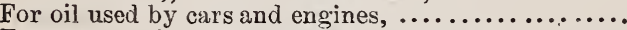

For waste and other material for cleaning,.........

For salaries, wages and incidental expenses, chargea-

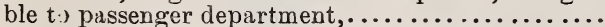

For salaries, wages and incidental expenses, chargeable to freight department,...................

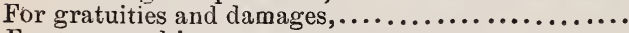

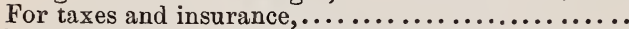

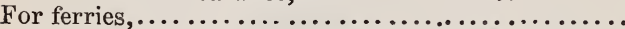

For repairs of station buildings, aqueducts, fixtures,

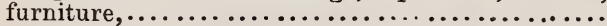

For renewals of iron, (laying down included else-

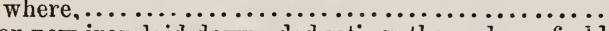

For new iron laid down, deducting the value of old

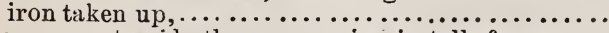

For amount paid other companies, in tolls for passengers and freight carried on their roads, specifying each company,$\ldots \ldots \ldots \ldots \ldots \ldots \ldots \ldots \ldots \ldots \ldots . . . \ldots \ldots$

For amount paid other companies, as rent for use of their roads, specifying each company............

For salaries of president, treasurer, superintendent, law expenses, cffice expenses of the above offices, and all other expenses not included in any of the

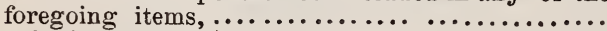

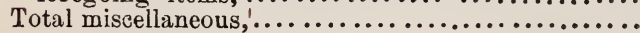

Total expenditures for working the road,..........

Total amount of interest paid during the year,.......

\section{Income during the year.}

\section{For Passengers:-}

1. On main road, including branches owned by

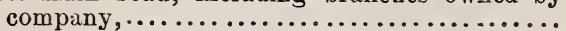

2. To and from other roals, specifyiug what:-

For Freight:-

1. On main road, and branches owned by com-

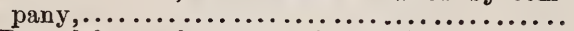

2. To and from other connecting roads,............

U. S. mails,

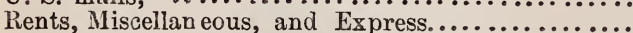

Total income,..........................

Net earnings, deducting expenses, $\ldots \ldots \ldots \ldots \ldots \ldots \ldots$
29

28

88 wheel, 24 wheel. 3568 wheel 2984 wheel. 40

7,958 99

31,24966

5,49194

1,127 36

27,26404

52,07668

3,07 ) 78

None

6,98251

14,31719

6,673 33

15,07364

None.

None.

10,45750

181,74862

326,10432

214,51782

153,47537

61,04245

307,13438

167,93600

139,19838

217,05466
9,94167

11,56511

543,15898 


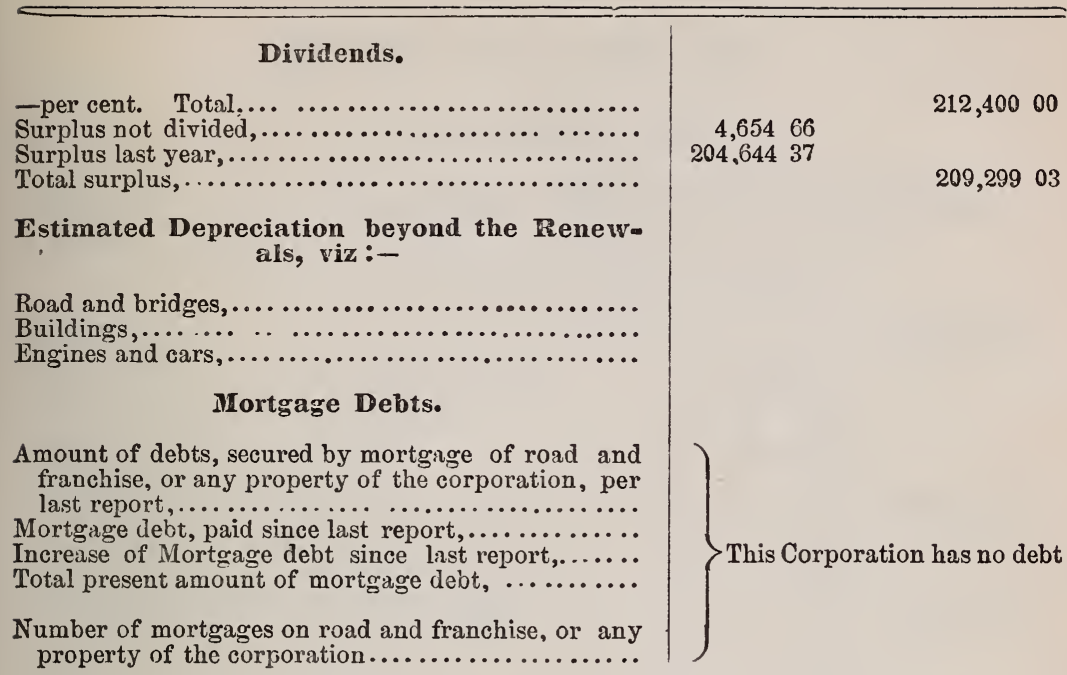

The foregoing report is respectfully submitted by

$\left.\begin{array}{l}\text { JOHN J. SWINT, } \\ \text { P. B. BRIGHAM, } \\ \text { WM. A. BRIGHAM, }\end{array}\right\} \begin{gathered}\text { Directors of the } \\ \text { Fitchburg Railroad } \\ \text { Corporation. }\end{gathered}$

Boston, December 28, 1861.

SuFroLK, ss. December 28, 1861.

Then personally appeared John J. Swift, P. B. Brigham and William A. Brigham, and severally made oath to the truth of the foregoing statement, by them subscribed, according to their best knowledge and belief.

Before,

W. B. STEARNS, Justice of the Peace.

Accidents. - February 5. A child of P. Tainter while crossin ${ }^{*}$ the track in front of an approaching train caught his foot between the rail and a plank, was thrown down and his leg thereby injured.

March 16. Charles A. Faulkner was fatally injured while crossing the track at Porter's.

April 19. John M'Lean, breakman, fell while climbing upon a car in the yard at Charlestown, and had his leg broken.

April 19. Harriet Haskell had her leg broken near Shirley Station. She saw the train approaching, but thinking she had ample time attempted to cross in front of the engine and was hit by the cow-catcher.

July 13. Michael Hennessy attempted to drive across the track in front of an approaching train which came in contact with his team, injuring his arm, killing the horse and breaki. $g$ the wagon.

August 1. Ellen Kerrigan, a child about two years old, was run over and fatally injured at a curve in the road. She was sitting upon the track at play.

October 13. George Swan, breakman, was found dead upon the track in Somerville, having fallen from his train. 



\section{R E P O R T}

OF THE DIRECTORS OF THE

\section{Fitchburg \& Worcester Railroad Corporation,}

For the Year Ending November 30, 1861.

\begin{tabular}{l|}
\hline \hline Capital stock, - \\
[Fixed by vote of Directors, Dec. 23d, 1857,] \\
Number of shares of capital stock issued, \\
Increase of capital since last Report, - \\
Capital paid in, per last Report, \\
Capital paid in, since last Report, \\
Total amount of capital stock paid in, \\
Funded debt, per last Report, \\
Funded debt paid since last Report, - \\
Funded debt, increase of, since last Report, \\
Total present amount of funded debt, \\
Floating debt, per last Report, \\
Floating debt, paid since last Report, - \\
Floating debt, increase of, since last Report, \\
Total present amount of floating debt, \\
Total present amount of funded and floating debt, \\
Average rate of interest per antium, paid during the year,
\end{tabular}

Average rate of interest per an:um, paid during the year,

Maximum amount of debts during the year,

Cost of Road and Equipment.

For graduation and Masonry, per last Report, -

For graduation and masonry, paid during the past year,

Total amount expended for graduation and masonry,

For wooden bridges, per last Report,

For wooden bridges, paid during the past year,

Total amount expended for wooden bridges,

Total amount expended for iron bridges, (if $\varepsilon n y$ ),

For superstructure, including iron, per last Report,

For superstructure including iron, paid during the past year,

Total amount expended for superstructurc, including iron,

For stations, buildings and fixtures, per last Report,

For stations, buildings and fixtures, paid during the past year,

Total amount expended for stations, buildings and fixtures,

For land, land-damages and fences, per last Report,

For land, land-damages and fences, paid during the past year,

Total amount expended for land, land-damages and ferices,

For locomotives, per last Repor

For locomotives, paid during the past year,

Total amount expended for locomotives, -

For passenger and baggage cars, per last Report,

For passenger and baggage cars, paid during the past

Total amount expended for passenger and baggage cars,

For merchandise cars per last Report,
$\$ 275,000$

2012 shares. 500

$217,325.70$

500

54,100

1,300

5,429

471

$217,825.70$

$\$ 500,000$

.

$55,400.00$

$5,900.00$

$61,300.00$

6 per cent.

61,300

$\$ 105,801.32$

None.

$1,677.92$

$105,801,32$

None.

None.

$100,267.83$

None.

21,991.79

$100,267.83$

None.

$32,092.88$

$21,991.79$

None.

None.

$18,867.19$

$32,092.88$

$18,867.19$

$6,594.24$

None.

$14,765.12$ 
For merchandise cars, paid during the past year,

Total amount expended for merchandise cars,

For engineering, per last Report,

For engineering, paid during the past year, -

Total amount expended for engineering, -

For agencies and other expenses, per last Report,

For agencies and other expenses, paid during the past year, - - - - -

Total amount expended for agencies and other ex-

penses, - -
Total cost of road and equipment, -

Amount of assets or property held by the corporation in addition to the cost of the road,

[Taken from reserved fund, and credited to construction account, Dec. 23, 1857,]

[Total cost of road,]

\section{Characteristics of Road.}

Length of road,

Length of single main track,

Length of double main track,

Length of branches owned by the company, stating whether they have a single or double track,

Aggregate length of sidings, and other tracks, excepting main track and branches,

Weight of rail per yard, in main road, -

Weight of rail per yard, in branch roads, (specify the different weights per yard), - -

Maximum grade, with its length, in main road,

Maximum grade, with its length, in branch roads,

Total rise and fall in main road,

Total rise and fall in branch roads,

Shortest radius of curvature, with length of curve, in

main road, -
Shortest radius of curvature, with length of curve, in branch roads,

Total degrees of curvature in main road,

Total degrees of curvature in branch roads, -

Total length of straight line in main road, -

Total length of straight line in branches, -

Aggregate length of wooden truss bridges, -

Aggregate length of all other wooden bridges, -

Aggregate length of iron bridges,

Whole length of road unfenced on both sides,

Number of public ways crossed at grade,

Number of railroads crossed at grade, -

Remarks,

Way stations for express trains,

Way stations for accommodation trains,

Flag stations, - - _ -

Whole number of way stations, - -

Whole number of flag stations, -

\section{Doings DURING the Year.}

Miles run by passenger trains, -

Miles run by freight trains,

Miles run by other trains,

Total miles run,

Number of passengers carried in the cars,

Number of passengers carried one mile,

Number of tons of merchandise carried in the cars,

Number of tons of merchandise carried one mile,
None.

$7,746.59$

$14,765.12$

None.

$$
24,079.81
$$

None.

None.

$58,884,69$

$275,000.00$

13.993 miles.

13.994 miles.

None.

None.

2.372 miles.

54 pounds.

None. 39.6 feet per mile for 3.902 miles,
except for .023 of a mile of 61 .077 feet to a mile, at the crossing of the Fitchburg Railroad.

304.3 feet.

None.

800 feet; length of curve 702 feet.

None.

$805^{\circ} 48^{\prime}$

None.

7.369 miles.

None.

All bridges have been re-

\} built of stone.

All fenced.

17

1

No express trains.

4

3

4

3
25,464

7,749

360

40,003

337,496

25,337

314,287 
Number of passengers carried one mile, to and from other roads,

Number of tons carried one mile, to and from other roads,

Rate of speed adopted for express passenger trains, including stops,

Average rate of speed actually attained by express passenger trains, including stops and detentions,

Rate of speed adopted for accommodation trains,

Rate of speed actually attained by accommodation trains,

including stops and detentions, -
Average rate of speed actually attained by special trains, including stops and detentions,

Average rate of speed adopted for freight trains, including stops,

Estimated weight in tons, of passenger cars, (not including passengers), hauled one mile,

Estimated weight in tons, of merchandise cars, (not including freight), hauled one mile,

\section{Expenditures for Working the Road.}

For repairs of road, maintenance of way, exclusive of wooden bridges, and renewals of iron,

For repairs of wooden bridges,

For wages of switchmen, average per month, \$

For wages of gate-keepers, average per month, $\$$

For wages of signal-men, average per month, $\$$

Far wages of watchmen, average per month, $\$$

Number of men employed exclusive of those engaged in construction,

For removing ice and snow, (this item to include all labor, tools, repairs, and extra steam power used),

For repairs of fences, gates, houses for signal men, gatekeepers, switchmen, tool houses,

Total for maintenance of way,

\section{Motive Power and Cars.}

For repairs of locomotives, - - -

For new locomotives to cover depreciation, -

For repairs of passenger cars, - - -

For new passenger cars, to cover depreciation,

For repairs of merchandise cars,

For new merchandise cars to cover depreciation,

For repairs of gravel and other cars,

Total for maintenance of motive power and cars,

Number of engines,

Number of passenger cars,

Number of baggage cars,

Number of merchandise cars,

Number of gravel cars,

\section{Misceltaneous.}

For fuel used by engines during the year, viz :

Wood, number of cords, 580. Cost of the same,

Coal, number of tons, (reckoning 2,240 lbs. to the ton,) 146. Cost of same,

For oil used for cars and engines,

For waste and other material for cleaning,

For salaries, wages, and incidental expenses, chargeable to passenger department,

For salaries, wages, and incidental expenses, chargeable to freight department,

For gratuities and damages,

For taxes and insurance,

For ferries,
304,442

307,206

22 miles per hour.

22 miles per hour.

$101-2$ miles per hour.

Not estimated.

Not estimated.

$4,454.15$

None.

260.90

15

158.27

$4,873.32$

887.68

709.97

936.85

$2,534.50$

3

3

1

14-26 of 37 long cars.

$3,551.99$

614.35

53.88

$2,484.95$

$2,876.76$

75.85

394.50 
For repairs of station buildings, aqueducts, fixtures, furniture [of this item there was paid for land,

For renewals of iron, including laying down, -

For new iron laid down,

For amount paid other companies, in tolls for passengers and freight carried on their roads, specifying each company.

For amount paid other companies, as rent for use of their roads, specifying each company,

For salaries of president, treasurer, superintendent, law expenses, office expenses of the above offices, and all other expenses, not included in any of the foregoing items, -

Total miscellaneous,

Total expenditures for working the road, -

Total amount of interest paid during the year,

\section{INCOME DURING THE YeAR.}

For Passengers :

1. On main road, including branches owned by company,

2. To and from other roads, specifying what,

For Freight:

1. On main road and branches owned by company,

2. To and from other connecting roads,

U. S. Mails,

Rents,

Total income,

Net earnings, after deducting expenses,

Dividends.

6 per cent. Total [on 1 st and $2 \mathrm{~d}$ class preferred stock], Surplus not divided, - $\quad-\quad$ - $\quad$ -

$\begin{array}{ccccc}\text { Surplus last year, } & - & - & - & -\end{array}$

$1,745.53$

\}$\quad 2,126.95$

$4,827.18$

$1,745.53$

$18,749.94$

$26,157.76$

$3,526.22$

$\$ 13,935.85$

$16,332.96$

$1,195.83$

$2,551.93$

$33,820.57$

$7,662.81$

$\$ 11,640.00$

$9,177.86$

$1,674.45$

Estimated Depreciation Beyond the Renewals, viz:

Of Road and Bridges,

Buildings,

Engines and cars,

\section{Mortgage Debts.}

Amount of debts secured by mortgage of road and franchise, or any property of the corporation, per last Report, - - - -

Mortgage debt paid since last Report, - -

Increase of mortgage debt since last Report, -

Present amount of mortgage debts, -

Number of mortgages on road and franchise, or any property of the corporation,

$$
\begin{aligned}
& \text { None. } \$ 54,100 \\
& 1,300
\end{aligned}
$$

$55,400.00$

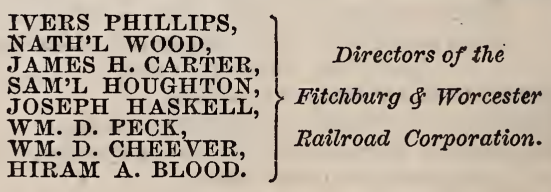

WorCester, ss. December 23, 1861. Then personally appeared Ivers Phillips, Nath'1 Wood, James H. Carter, Sam'l Houghton, Wm. D. Peck, Joseph Haskell, W. D. Cheever, and $\mathrm{H}$. A. Blood, and severally made oath to the truth of the foregoing statement by them subscribed. 


\section{NINTH ANNUAL REPORT}

- OF THE-

Hampshire and Hampden Railroad Company,

FOR 1861. 



\section{NINTH ANNUAL REPORT}

OF THE

\section{Hampshire \& Hampden Railroad Company.}

Report of the Hampshire \& Hampden Railroad, under the General Statutes, Chapter 63, Sections 132 to 135 .

Capital Stock,

Number of shares of capital stock issued,

Increase of capital, since last Report,

Capital paid in, per last Report,

Capital paid in since last Report,

Total amount of capital stock paid in,

Funded debt, per last Report.

Funded debt paid since last Report, .

Funded debt, increase of, since last Report, .

Total present amount of funded debt, .

Floating debt, per last Report,

Floating debt paid since last Report,

Floating debt, increase of, since last Report,

Total present amount of floating debt,

Total present amount of funded and floating debt,

Average rate of interest per annum, paid during the year,

Maximum amount of debts diring the year,

\section{Cost of RoAd and EQUiPMENT.}

For graduation and masonry, per last Report,

For graduation and masonry, paid during the past year,

Total amount expended for graduation and masonry, .

For wooden bridges, per last Report,

For wooden bridges, paid during the past year, Total amount expended for wooden bridges.

Total amount expended for iron bridges, (if any,)

For superstructure, including iron, per last Report,

For superstructure, including iron, paid during the past year,

Total amount expended for superstructure, including iron,

For stations, buildings and fixtures, per last Report,

For stations, buildings and fixtures, paid during the past year,
$\$ 375,000,00$

$\$ 292,950,90$

$303,014,10$

$78,577,70$

$303,014,00$

$19,129,20$

$97,706,90$

$400,720,90$

Six per cent.

$\$ 191,637,76$

$26,065,33$

$191,637,76$

$26,065,33$

$198,547,69$

$198,547,69$

$33,115,97$ 
Total amount expended for stations, buildings and fixtures,

For land, land-damages and fences, per last Report,

For land, land damages and fences, paid during the past year,

Total amount expended for land, land-damaages and fences,

For locomotives, per last Report, owned by New Haven \& Northampton Co.

For locomotives, paid during the past year, :

Total amount expended for locomotives, owned by New Haven \& Northampton Co.

For passenger and baggage cars, per last Report,

For passenger and baggage cars, paid during the past year, by New Haven \& N. Co.

Total amount expended for passenger and baggage cars, by New Haven \& N. Co.

For merchandise cars, per last report,

For merchandise cars, paid during the past year, Total amount expended for merchandise cars,

For engineering,agencies, discount on bonds,\&c. per last Report,

For engineering, paid during the past year,

Total amount expended for engineering, agencies, discount on bonds, \& c.

Total cost of road and equipment,

Amount of assets or property held by the corporation in addition to the cost of the road,

\section{Characteristics OF Road.}

Length of Roads, 25 miles in Mass.\& 4.78 in Ct.

Length of single main track,

Length of double main track,

Length of branches owned by the Company, stating whether they have a single or double track,

Aggregate length of sidings, and other tracks, excepting main tracks and branches,

Weight of rail, per yard, in main road,

Weight of rail, per yard, in branch roads, :

Specify the different weights per yard,

Maximum grade, with its length, in main road,

Maximum grade, with its length, in branch roads,

Total rise and fall in main road,

Total rise and fall in branch roads

Shortest radius of curvature, with length of curve in main road,

Shortest radius of curvature, with length of curve, in branch roads,

Total degrees of curvature, in main road,

Total degrees of curvature, in branch roads,

Total length of straight line, in main road, . Total length of straight line, in branches, Aggregate length of wooden truss bridges, . Aggregate length of all other wooden bridges, Aggregate length of iron bridges,

29.78 miles.

29.78 miles.

$51,453,61$

$23,619,89$

$23,619,89$

$5,128,56$

$5,128,56$

$77,112,26$

$77,112,26$

$\$ 596,681,07$

3 miles

56 and $58 \mathrm{lbs}$.

40 feet for 5 miles.

335 feet rise, $273 \mathrm{ft}$. fall.

1000 feet, $1500 \mathrm{ft}$. long.

$1003^{\circ}$

16.10 miles.

842 feet.

136 feet.

None. 
Whole length of road unfenced on both sides,

Number of public ways crossed at grade, .

Number of rail roads crossed at grade,

Remarks,
Way stations for express trains,

Way stations for accommodation trains,

Flag stations,

Whole number of way stations, $5^{\circ}$ in Mass. 1 in Conn.

Whole number of flag stations, $\cdot{ }^{\circ}$

\section{DoINGS DURING THE YeaR.}

Miles run by passenger trains,

Miles run by freight trains, .

Miles run by other trains, . . $\quad$.

Total miles run,

Number of passengers carried in the cars,

Number of passengers carried one mile,

Number of tons of merchandise carried in the cars,

Number of tons of merchandise carried one mile,

Number of passengers carried one mile, to and from other roads,

Number of tons carried one mile, to and from other roads, .

Rate of speed adopted for express passenger trains, including stops,

Average rate of speed actually attained by - express passenger trains, including stops and detentions,

Rate of speed adopted for accommodation trains,

Rate of speed actually attained by accommodation trains, including stops and detentions,

Average rate of speed actually attained by special trains, including stops and detentions,

Average rate of speed adopted for freight trains, including stops,

Estimated weight in tons of passenger cars, (not including passengers,) hauled one mile,

Estimated weight in tons of merchandise cars, (not including freight,) hauled one mile, .

\section{EXPENDITURES FOR WORKING THE ROAD.}

For repairs of Road, maintenance of way exclusive of wooden bridges, and renewals of iron, including $2000 \mathrm{ft}$. new turnouts,

For repairs of wooden bridges,

For wages of switchmen, average per month, $\$ 26.00$,

For wages of gate-keepers, average per month, None.

For wages of signal-men, average per month, None.

For wages of watchmen, average per month, $\$ 25.00$.

Number of men employed, exclusive of those engaged in construction,
3 miles.

34 in Mass. and 4 in Conn.

One, Western Railroad.

2.
4.
2.
6.
2.

2.

31,294

18,642

1,580

29,079

51,516

331,257

18.310

$.326,382$

110,155

388,977

26 miles per hour.

26 miles per hour.

16 miles per hour.

16 miles per hour.

16 miles per hour.

$\$ 7,043,67$

276,00

40. 
For removing ice and snow, (this item to include all labor, tools, repairs, and extra steam-power used,)

For repairs of fences, gates, houses for signalmen, gate-keepers, switchmen, tool-houses, Total for maintenance of way,

\section{Motive Power and Cars.}

For repairs of locomotives,

For new locomotives, to cover depreciation, .

For repairs of passenger cars, and Freight Rents paid N. Y. \& N. H. R. R. Co.

For new passenger cars, to cover depreciation,

For repairs of merchandise cars,

For new merchandise cars, to cover depreciation,

For repairs of gravel and other cars,

Total for maintenance of motive power and cars,

Number of engines, owned by New Haven and Northampton $\mathrm{Co}$.

Number of passenger cars, owned by New Haven \& Northampton Co.

Number of baggage cars, owned by New Haven $\&$ Northampton Co.

Number of merchandise cars, . . .

Number of gravel cars,

\section{Miscellaneous.}

For fuel used by engines during the year. viz.: Wood, number of cords, 965. Cost of the same,

Coal, number of tons, (reckoning 2,240 lbs. to the ton,) -.. Cost of Coal,

For oil used by cars and engines,

For waste and other material for cleaning, :

For salaries, wages, and incidental expenses, chargeable to passenger department,

For salaries, wages, and incidental expenses, chargeable to freight department, .

For gratuities and damages, .

For taxes and insurance,

For ferries, . . . None.

For repairs of station buildings, aqueducts, fixtures, furniture,

For renewals of iron, including laying down,

For new iron laid down,

For amount paid other companies, in tolls for passengers and freight carried on their roads, specifying each company,

For amount paid other companies, as rent for use of their roads, specifying each company,

For Finishing Telegraph Line,

For salaries of president, treasurer, superintendent, law expenses, office expenses of the above offices, and all other expenses not included in any of the foregoing items, Total Miscellaneous,

Total expenditures for working the road,
$\$ 1,133,99$

70,00

$\$ 8,523,66$

$\$ 893,83$

$2,669,32$

•

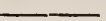

$\$ 2,963,15$

3

2

I

$\$ 3,515,95$

427,17

80,03

$10,002,68$

272,00

68,64

$1,287,50$

6,10

$1,705,21$ 
INCOME DURING THE YeAR.

For Passengers:-

On main road, including branches owned by company,

For Freight :-

On main road and branches owned by company,

U. S. Mails,

Rents, and .

Total income,

Net earnings, after deducting expenses,

\section{Drvidends.}

per cent. Total,

Surplus not divided,

Surplus, last year,

Total surplus,

\section{Mortgage Debts.}

Amount of debts secured by mortgage of road and franchise, or any property of the Corporation, per last Report,

Mortgage debt, paid since last Report,

Increase of mortgage debt, since last Report,

Present amount of mortgage debt,

Number of mortgages on road and franchise, or any property of the Corporation, .

$\$ 303,014,00$
\$ $28,600,35$

$14,241,33$

$2,195,99$

479,89

$303,014,00$

Two.

\section{NoTE.}

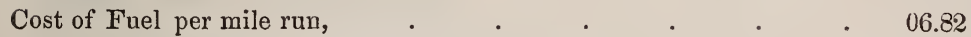

" Oil and Waste per mile run, . $\quad . \quad 0.0 .00 .98$

“ Repairs of Engines, per mile run, . . . . . 01.73

Feet of Wood used " " . . . . . . . 2.39

Total cost of Operating Road " " . . . . . . 56.06

6

"6

" in lengtll, per year,

$\$ 972,53$

This Road is leased to the New Haven \& Northampton Co. for Nine Hundred and Ninety Nine years, the lessees to pay Running Expenses, keep the Road in Repair, pay the Interest on First. Mortgage Bonds, and pay the Bonds at maturity; and includes the Farmington Valley Railroad, $4 \frac{3}{4}$ miles long, in Connecticut, as per lease. The Equipment is owned by the New Haven and Northampton Company. 


\section{ACCIDENTS.}

March 9.-Theodore Bartlett, acting Brakeman, was eaught between two cars while coupling, at Westfield, and injured so be died same night. He was not the regular Brakeman, had no authority for being with the train, and was specially warned not to attempt the coupling, but persisted in doing so.

June 12.-William N. Lee, an intemperate man, was run over, at Granby, while trying to jump on to a passing freight train, and was injured so he died the same day.

Signed,

$\left.\begin{array}{l}\text { WM. JOHNSON, } \\ \text { JOSEPH E. SHEFFIELD, } \\ \text { S. D. PARDEE, } \\ \text { IRA YEAMANS, JR. }\end{array}\right\} \begin{gathered}\text { Directors of the } \\ \text { Hampshire and } \\ \text { Hampden Rail } \\ \text { Road Corporation. }\end{gathered}$

New Haven County, ss., December 26, 1861. Then personally appeared Wm. Johnson, Joseph E. Sheffield, and Stephen D. Pardee, and severally made oath to the truth of the foregoing statement by them subscribed, according to their best knowledge and belief.

Before me, JOSEPH DOWNS, Notary Public.

State of New York, City and County of New YoRk, ss. On this 27th day of December, 1861, personally appeared before me Ira Yeamans, Jr. and personally made oath to the truth of the foregoing statement by him subscribed, to the best of his knowledge and belief.

R. M. HEDDEN, Notary Public. 


\section{HARTFORD AND NEW HAVEN RAIL- ROAD COMPANY.}

Report of the Directors of the Hartford and New Haven Railroad Corporation for the year ending November 30, 1861.

Capital Stock, [allowed by the Charter in Mass., ] Number of shares of capital stock issued,

Increase of capital, since last Report, Capital paid in, per last Report,

Capital paid in since last Report,

Total amount of capital stock paid in, in Mass. and Conn.,

Funded debt, per last Report,

Funded debt paid since last Report

Funded debt, increase of since last Report,

Total present amount of funded debt,

Floating debt, per last Report,

Floating debt paid since last Report,

Floating debt, increase of, since last Report,

Total present amount of floating debt,

Total present amount of funded and floating debt,

Average rate of interest per annum, paid during the year,

Maximum amount of debts during the year, Cost of Road and EQuipment.

For graduation and masonry, per last Report,

For graduation and masonry, paid during the past year,

Total amount expended for graduation and masonry,

For wooden bridges, per last Report,

For wooden bridges, paid during the past year,

Total amount expended for wooden bridges,
$\$ 300,000$

23,500

( The cap. stock has been merged in the cap.stock of H.\& N.H.R.R.Co., in Conn.,accord'g to the provisions of the chart'r and amend'nts thereof.

$\$ 2,350,000$

929,000

2,000

927,000

927,000

6 per cent.

927,000

$247,895.27$ 
Total amount expended for iron bridges, (if any,)

For superstructure, including iron, per last Report,

For superstructure, including iron, paid during the past year,

Total amount expended for superstructure, including iron,

For stations, buildings and fixtures, per last Report,

For stations, buildings and fixtures, paid during the past year,

Total amount expended for stations, buildings and fixtures,

For land, land-damages and fences, per last Report,

For land, land-damages and fences, paid during the past year,

Total amount expended for land,

For locomotives, per last Report,

For locomotives, paid during the past year,

Total amount expended for locomotives,

For passenger and baggage cars, per last Rep't,

For passenger and baggage cars, paid during the past year,

Total amount expended for passenger and baggage cars,

For merchandise cars, per last Report,

For merchandise cars, paid during the past year, Total amount expended for merchandise cars,

For engineering, per last Report,

For engineering, paid during the past year,

Total amount expended for engineering,

For agencies and other expenses, per last Report,

For agencies and other expenses, paid during the past year,

Total amount expended for agencies and other expenses,

'Total cost of road and equipment,

Amount of assets or property held by the cor poration in addition to the cost of the road,

\section{Characteristics of Road.}

Length of road,

Lenoth of single main track

Length of double main track, . . .

Length of branches owned by the Company, stating whether they have a single or double track,

Aggregate length $\dot{\vec{h}}$ of sidings, and $\dot{\vec{d}}$ other tracks, excepting main track and branches, .
$247,895.27$

$17,132.39$

$17,132.39$

$44,267.77$
$5 \frac{87}{100}$ miles.

$5 \frac{87}{100} \quad 6$

$2 \frac{48}{3 \frac{2}{0}} \quad$ " 
Weight of rail, per yard, in main road,

Weight of rail, per yard, in branch roads, (specify the different weights per yard,)

Maximum grade, with its length, in main road,

Maximum grade, with its length, in branch roads,

Total rise and fall in main road,

Total rise and fall in branch roads,

Shortest radius of curvature, with length of curve, in main road,

Shortest radius of curvature, with length of curve, in branch roads,

Total degrees of curvature, in main road,

Total degrees of curvature, in branch roads,

Total length of straight line, in main road,

Total length of straight line, in branches,

Aggregate length of wooden truss bridges,

Aggregate length of all other wooden bridges,

Aggregate length of iron bridges,

Whole length of road unfenced on both sides,

Number of public ways crossed at grade, .

Number of railroads crossed at grade, .

Remarks,

Way stations for express trains,

Way stations for accommodation trains, .

Flag stations,

Whole number of way stations, . . .

Whole number of flag stations,

DoIngs DURING THE Year.

$\left.\begin{array}{l}\text { Miles run by passenger trains, . . . . } \\ \text { Miles run by freight trains, . . . }\end{array}\right\}$

Miles run by other trains, . . . .

Total miles run,

Number of passengers carried in the cars,

Number of passengers carried one mile,

Number of tons of merchandise carried in the cars,

Number of tons of merchandise carried one mile,

Number of passengers carried one mile, to and from other roads,

Number of tons carried one mile, to and from other roads,

Rate of speed adopted for express passenger trains, including stops,

Average rate of speed actually attained by express passenger trains, including stops and detentions,

Rate of speed adopted for accommodation trains,

Rate of speed actually attained by accommodation trains, including stops and detentions,
57 lbs.

$57 \mathrm{lbs}$.

$17 \frac{53}{100} \mathrm{ft}$; length $\frac{5 \frac{2}{1}}{0} \overline{0}$

$31 \frac{6}{1} \frac{1}{0}$

$477 \frac{1}{2} \mathrm{ft}$; length $\frac{1}{10}$ mile.

$227^{\circ}$

$4 \frac{25}{10}$

one, Long Meadow.

one.

$1,052,578$

113,461

567,305

462,509

302,322

33 miles.

33 miles.

27 miles. 
Average rate of speed actually attained by special trains, including stops and detentions,

Average rate of speed adopted for freight trains, including stops,

Estimated weight in tons of passenger cars, (not including passengers, hauled one mile,

Estimated weight in tons of merchandise cars, (not including freight,) hauled one mile, .

Expenditures for Working THe RoAd.

For repairs of road, maintenance of way, exclusive of wooden bridges, and renewals of iron,

For repairs of wooden bridges,

For wages of switchmen, average per month, $\$ 30.50$,

For wages of gate-keepers, average per month, $\$ 26.00$

For wages of signal-men, average per month,

For wages of watchmen, average per month, $\$ 30.00$,

Number of men employed, exclusive of those engaged in construction, .

For removing ice and snow, (this item to include all labor, tools, repairs, and extra steampower used,)

For repairs of fences, gates, houses for signalmen, gate-keepers, switchmen, tool-houses,

Total for maintenance of way,

Motive Power and Cars.

For repairs of locomotives,

For new locomotives, to cover depreciation,

For repairs of passenger cars,

For new passenger cars, to cover depreciation,

For repairs of merchanise cars, .

For new merchandise cars, to cover depreciation,

For repairs of gravel and other cars,

Total for maintenance of motive power and cars,

Number of engines,

Number of passenger cars,

Number of baggage cars,

Number of merchandise cars,

Number of gravel cars,

\section{Miscellaneous.}

For fuel used by engines during the year, viz. :-

Wood, number of cords, ___ Cost of the same,

Coal, number of tons, (reckoning 2,240 lbs. to the ton,)

For oil used by cars and engines,

For waste and other material for cleaning,
27 miles.

12

Operated and paid by the H. \& N. H. R. R. Co., in Conn.

Owned and operated by the H. \& N. H. R. R. Co., as per former Report. 
For salaries, wages and incidental expenses, chargeable to passenger department,

For salaries, wages, and incidental expenses, chargeable to freight department,

For gratuities and damages,

For taxes and insurance,

For ferries,

For repairs of station buildings, aqueducts, fixtures, furniture, . . . . .

For renewals of iron, including laying down,

For new iron laid down, deducting the value of old iron taken up,

For amount paid other companies, in tolls for passengers and freight carried on their roads, specifying each company,

For amount paid other companies, as rent for use of their road, specifying each company,

For salaries of president, treasurer, superintendent, law expenses, office expenses, of the above offices, and all other expenses not included in any of the foregoing items,

Total Miscellaneous,

Total expenditures for working the road,

Total amount of interest paid during the year, Income During the Year.

For Passengers :-

1. On main road including branches owned by company, · $\cdot \dot{0} \cdot \dot{0}$

2. To and from other roads, specifying what, For Freight:-

1. On main road and branches owned by company,

2. To and from other connecting roads,

U. S. Mails,

Rents,

Total income,

Net earning after deducting expenses, .

\section{Dividends.}

Per cent. Total,

Surplus not divided,

Surplus last year,

Total surplus,

Estimated Depreciation beyond the ReNEWALS, VIZ. :

Of roads and bridges,

Buildings,

Engines and cars,

Mortgage Debts.

Amount of debts secured by mortgage of road and franchise, or any property of the corporation, per last Report,
Paid by the H. \& N. H.

R. R. Co., in Conn., as performer report.

To the H. \& N. H. R. R. Co., in Conn., as per former Report.

To the H. \& N. H. R. R. Co., in Conn., as per former Report. 
Mortgage debt paid since last Report, Increase of mortgage debt since last Report, Present amount of mortgage debts,

Number of mortgages on road and franchise, or any property of the corporation,

$\left.\begin{array}{l}\text { CHARLES. F POND, } \\ \text { JULIUS CATLIN, } \\ \text { EZRA C. READ, } \\ \text { SAMUEL H. PARSONS, } \\ \text { CHESTER W. CHAPIN, }\end{array}\right\} \begin{gathered}\text { Directors of the Hartford } \\ \text { and New Haven } \\ \text { Railroad Corporation. }\end{gathered}$

Hartford County, ss. December 23, 1861.

Then personally appeared, Charles F. Pond, Julius Catlin, Ezra C. Read, and Samuel H. Parsons, and severally made oath to the truth of the foregoing statement by them subscribed, to their best knowledge and belief.

\section{Before}

JOHN T. McMANUS,

Notary Public.

Hampden County, ss.

December 25, 1861.

Then personally appeared, Chester W. Chapin, and made oath to the truth of the foregoing statement, by him subscribed, to the best of his knowledge and belief.

Before

WILLIAM K. BAKER, Justice of the Peace. 



\section{REPORT}

OF THE

\section{I R E T O R S}

OF THE

\section{HORN POND BRANCH RAILROAD}

\section{CORPORATION.}

FOR THE YEAR ENDING NOVEMBER 30, 1861.

B OSTON:

WRIGHT \& POTTER, PRINTERS, 4 SPRING LANE. 



\section{REPORT OF THE DIRECTORS}

OF THE

\section{HORN POND BRANCH R. R. CORPORATION.}

For the year ending November 30, 1861. General Statutes, Chap.63, Sects. 132-135.

1. Capital stock,

2. Number of shares of capital stock issued, :

3. Increase of capital, since last report,

4. Capital paid in, per last report, .

5. Capital paid in, since last report, .

6. Total amount of capital stock paid in, .

7. Funded debt, per last report,

8. Funded debt, paid since last report,

9. Funded debt, increase of, since last report,

10. Total present amount of funded debt, .

11. Floating debt, per last report, .

12. Floating debt, paid since last report, .

13. Floating debt, increase of, since last report,

14. Total present amount of floating debt, .

15. Total present amount of funded and floating debt, .

16. Average rate of interest per annum, paid during the year,

17. Maximum amount of debts during the year,

\section{Cost of Road and Equipment.}

18. For graduation and masonry, per last report,

19. For graduation and masonry, paid during the past year, masonry,

21. For wooden bridges, per last report,

22. For wooden bridges, paid during the past year, .

23. Total amount expended for wooden bridges,

24. Total amount expended for iron bridges (if any),

25. For superstructure, including iron, per last report,

26. For superstructure, including iron, paid during the past year,

27. Total amount expended for superstructure, including iron,

28. For stations, buildings and fixtures, per last report,

29. For stations, buildings and fixtures, paid during the past year, .

30

Total amount expended for stations, buildings and fixtures, .

31. For land, land-damages and fences, per last report,

32. For land, land-damages and fences, paid during the past year,

33. Total amount expended for land, land-damages and fences,

.

(1)

$\begin{array}{cc}- & \$ 10,00000 \\ - & - \\ \$ 2,000 & - \\ - & - \\ - & 2,00000 \\ - & - \\ - & -\end{array}$

$13,238 \quad 46$

$-$

$13,238 \quad 46$

13,23846

$\$ 1,76696$

$\$ 3,946 \quad 05$

1,76696

$-$

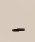

-

- 
34. For locomotives, per last report,

35. For locomotives, paid during the past year,

36 .

Total amount expended for locomotives,

37. For passenger and baggage cars, per last report

38. For passenger and baggage cars, paid during the

39. past year,

Total amount expended for passenger and baggage cars,

40. For merchandise cars, per last report,

41. For merchandise cars, paid during the past year, .

42. Total amount expended for merchandise cars,

43. For engineering, per last report, .

44. For engineering, paid during the past year

45. Total amount expended for engineering,

46. For agencies and other expenses, per last report, .

47. For agencies and other expenses, paid during the

48. Total amount expended for agencies and other expenses,

Total sost of road and equipment, :

49.

50. Amount of assets or property held by the corporation in addition to the cost of the road, .

Characteristics of Road.

51. Length of road,

52. Length of single main track,

53. Length of double main track,

54. Length of branches owned by the Company, stating whether they have a single or double track,

55. Aggregate length of sidings, and other tracks, excepting main track and branches,

56. Weight of rail, per yard, in main road,

57. Weight of rail, per yard, in branch roads, (specify the different weights per vard,)

58. Maximum grade, with its length, in main road,

59. Maximum grade, with its length, in branch roads,

60. Total rise and tall in main road,

61. Total rise and fall in branch roads,

62. Shortest radius of curvature, with length of curve, in main road,

63. Shortest rodius of curvature, with length of curve, in brauch roads,

64. Total degrees of curvature, in main road,

65. Total degrees of curvature, in branch roads,

66. Total length of straight line, in main road,

67. Total length of straight line, in branches,

68. Aggregate length of wooden truss bridges,

69. Aggregate length of all other wooden bridges,

70. Aggregate length of iron bridges, .

71 Whole length of road unfenced on both sides,

72. Number ot public ways crossed at grade, .

73. Number of railroads crossed at grade,

74. Pemarks, .

75. Way stations for express trains, •

76. Way stations for accommodation trains,

77. Flag statious,

78. Whole number of way stations,

79. Whole number of flag stations,
Nothing; road being operated by Boston and Lowell Railroad.

$\$ 924 \quad 15$

Nothing; road being operated by Boston and Lowell Railroad.

\begin{abstract}
About 3,500 feet.
A bout 3,500 feet.

None.
\end{abstract}

None.

56 lbs.

$380 ; 6 \mathrm{ft}$. per mile for $450 \mathrm{ft}$.

1,707 feet.

501,629 feet for 775,554 feet.

217 deg. 9 min. 14 sec.

650 fəet.

One.

None.

None.

None.

One.

None.

One. 


\section{Doings During the Year.}

80. Miles run by passenger trains, .

81. Miles run by freight trains, .

82. Miles run by other trains,. .

83. Total miles run, $\cdot$.

85. Number of passengers carried one mile,

86. Number of tons of merchandise carried in the cars,

87. Number of tons of merchandise carried one mile,

88. Number of passengers carried one mile, to and from other roads,

89. Number of tons carried one mile, to and from other roads, . . . . . .

90. Rate of speed adopted for express passenger trains, including stops, .

91. Average rate of speed actually attained by express passenger trains, including stops and detentions,

92. Rate of speed adopted for accommodation trains, .

93. Rate of speed actually attained by accommodation trains, including stops and detentions, .

94. Average rate of speed actually attained by special trains, including stops and detentions, .

95. A verage rate of speed adopted for freight trains, including stops, . . . . .

96. Estimated weight in tons of passenger cars, (not including passengers,) hauled one mile,

97. Estimated weight in tons of merchandise cars, (not including freight, ) hauled one mile, .

\section{EXPENDITURES FOR WoRKing the ROAD.}

98. For repairs of road, maintenance of way, exclu- $\quad$ sive of wooden bridges, and renewals of iron, .

99. For repairs of wooden bridges,

100. For wages of switchmen, average per month, .

101. For wages of gate-keepers, average per month, .

102. For wages of signal-men, average per month, .

103. For wages of watchmen, average per month, .

104. Number of men employed, exclusive of those engaged in construction, .

105. For removing ice and snow, (this item to include all labor, tools, repairs, and extra steam-power used,) .

106. For repairs of fences, gates, houses for signal-men, gate-keepers, switchmen, tool-houses, .

107.

Total for maintenance of way,

\section{Motive Power and Cars.}

108. For repairs of locomotives,

109. For new locomotives, to cover depreciation,

110. For repairs of passenger cars,
111. For new passenger cars, to cover depreciation, .
None.

575 miles.

None.

575 miles.

None.

None.

20,228 tons, carried about 3,500 feet.

None.

20,228 tons.

No such trains.

8 miles per hour.

None hauled.

19,000 .

Road operated by Boston and Lowell Railroad.

Road operated by Boston and Lowell Railroad. 
112. For repairs of merchandise cars, .

113. For new merchandise cars, to cover depreciation,

114. For repairs of gravel and other cars,

115. Total for maintenance of motive power and

116. Number of engines

117. Number of passenger cars,

118. Number of baggage cars, .

119. Number of merchandise cars,

120. Number of gravel cars, .

\section{Miscellaneous.}

121. For fuel used by engines during the year, viz. :1. Wood, number of cords, - Cost of the same,

2. Coal, number of tons, (reckoning $2,240 \mathrm{lbs}$. to the ton,) . Cost of same,

122. For oil used by cars and engines,

123. For waste and other material for cleaning,

124. For salaries, wages and incidental expenses, chargeable to passenger department,

125. For salaries, wages and incidental expenses, chargeable to freight department,

126. For gratuities and damages,

127. For taxes and insurance,

128. For ferries,

129. For repairs of station buildings, aqueducts, fixtures, furniture,

130. For renewals of iron, including laying down, .

131. For new iron laid down, deducting the value of old iron taken up,

132. For amount paid other companies, in tolls for passengers and freight carried on their roads, specifying each company,

133. For amount paid other companies, as rent for use of their roads, specifying each company, .

134. For salaries of president, treasurer, superintendent, law expenses, office expenses of the above offices, and all other expenses not included in any of the foregoing items,

135.
Road operated by Boston and Lowell Railroad.
Road operated by Boston and Lowell Railroad.

136. Total expenditures for working the road,

137. Total amount of interest paid during the year,

\section{INCOME DURING THE Year.}

138. For Passengers :-

1. On main road, including branches owned by company,

2. To and from other roads, specifying what, 139. For Freight:-

1. On main road and branches owned by company,

2. To and from other connecting roads,

140. U. S. Mails,

141. Rents,

142. Total income,

143. Net earnings, after deducting expenses, .

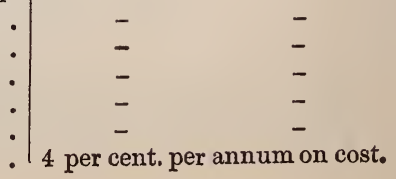




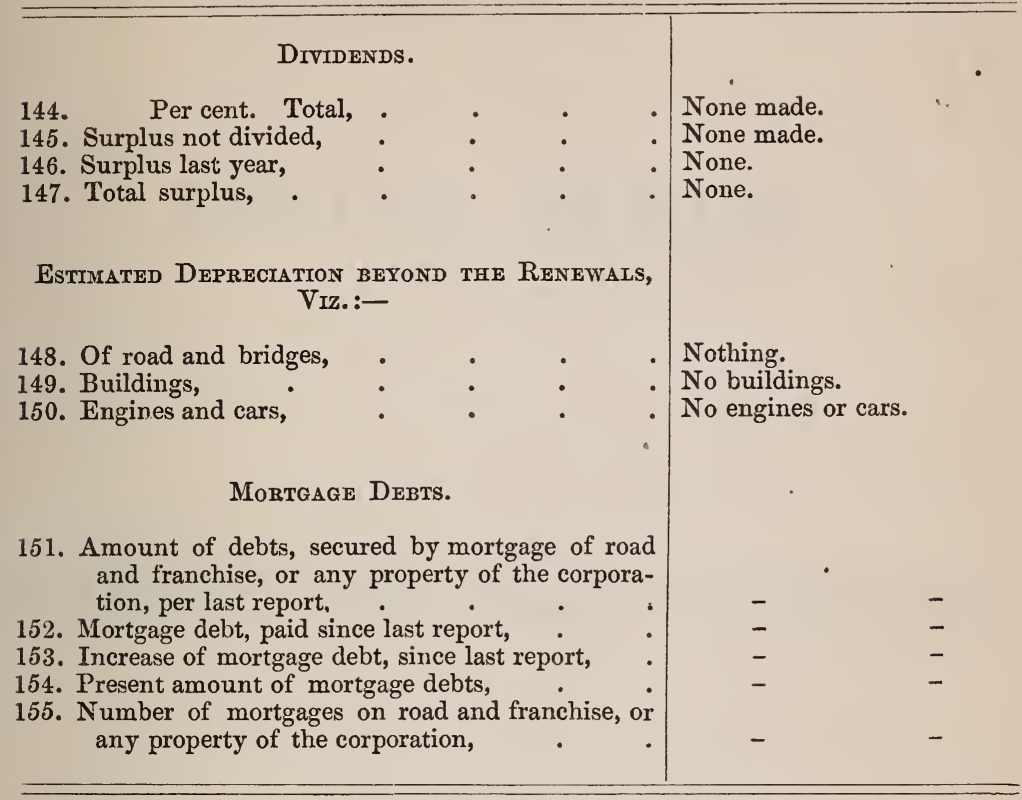

GEORGE DRAPER,

DANIEL DRAPER,

S. HANCOCK, JR.,

WM. P. DRAPER,

Directors of the Horn Pond Branch Railroad Corporation.

Suffork, ss., December 31, 1861. Then personally appeared George Draper, Daniel Draper, S. Hancock, Jr., and Wm. P. Draper, and severally made oath to the truth of the foregoing statement, by them subscribed.

Before

DANIEL SHARP, Justice of the Peace. 



\title{
SEVENTEENTH
}

\section{ANNUAL REPORT}

OF THE

\section{LEXINGTON AND WEST CAMBRIDGE}

\author{
R A I L R 0 A D C 0 M PA NY,
}

1861 .

BOSTON:

PRESS OF T. R. MARVIN \& SON, 42 CONGRESS STREET. 1861 . 
ix 


\section{SEVENTEENTH ANNUAL REPORT}

OF THE

\section{LEXINGTON AND WEST CAMBRIDGE RAIL- ROAD COMPANY.}

Capital stock,

Number of shares of capital stock issued,

Increase of capital, since last report,

Capital paid in, per last report,

Capital paid in, since last report,

Total amount of capital stock paid in

Funded debt, per last report,

Funded debt, paid since last report,

Funded debt, increase of, since last report,

Total present amount of funded debt,

Floating debt, per last report,

Floating debt, paid since last report,

Floating debt, increase of, since last report,

Total present amount of floating debt,

Total present amount of funded and floating debt, .

Average rate of interest per annum, paid during the year, .

Maximum amount of debts during the year,

\section{Cost of Road and Equipment.}

For graduation and masonry, per last report,

For graduation and masonry paid during the past year,

Total amount expended for graduation and masonry,

For wooden bridges, per last report,

For wooden bridges paid during the past year,

Total amount expended for wooden bridges,

Total amount expended for iron bridges, (if any,) .

For superstructure, including iron, per last report, .

For superstructure, including iron, paid during the past year,

Total amount expended for superstructure, including iron, .

For stations, buildings and fixtures, per last report,

For stations, buildings and fixtures, paid during the past year,

Total amount expended for stations, buildings and fixtures,

For land, land-damages and fences, per last report, For land, jland-damages and fences, paid during the past year,

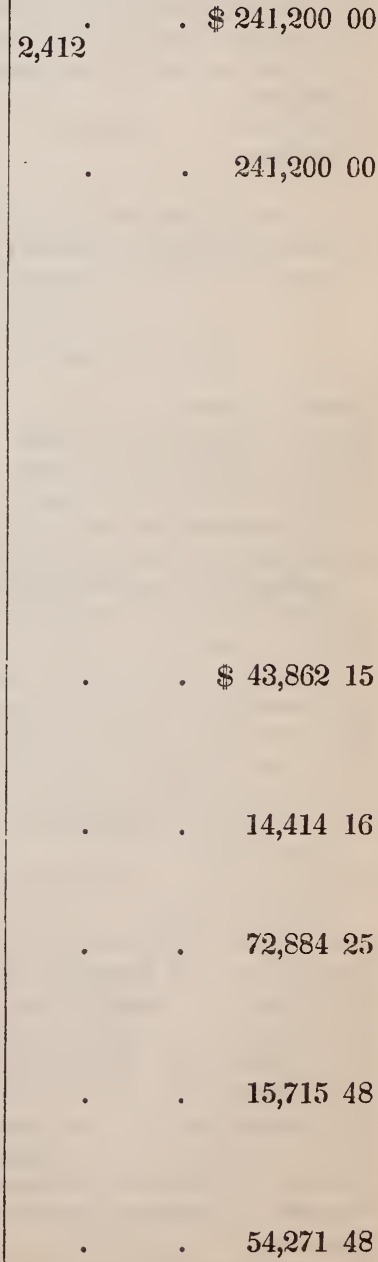


Total amount expended for land, land-damages and fences,

For locomotives, per last report, . .

For locomotives, paid during the past year,

Total amount expended for locomotives, .

For passenger and baggage cars, per last report,

For passenger and baggage cars, paid during the past year,

Total amount expended for passenger and baggage cars,

For merchandise cars, per last report,

For merchandise cars, paid during the past year,

Total amount expended for merchandise cars,

For engineering, per last report,

For engineering, paid during the past year,

Total amount expended for engineering, .

For agencies and other expenses, per last report,

For agencies and other expenses, paid during the past year,

Total amount expended for agencies and other expenses,

Total cost of road and equipment, .

Amount of assets or property held by the corporation in addition to the cost of the road, .

\section{Characteristics of Road.}

Length of road,

Length of single main track,

Length of double main track,

Length of branches owned by the company, stating whether they have a single or double track, .

Aggregate length of sidings, and other tracks, excepting main tracks and branches,

Weight of rail per yard in main road,

Weight of rail per yard in branch roads, (specify the different weights per yard,)

Maximum grade, with its length, in main road,

Maximuın grade, with its length, in branch roads, .

Total rise and fall in main road,

Total rise and fall in branch roads,

Shortest radius of curvature, with length of curve, in main road,

Shortest radius of curvature, with length of curve, in branch roads, .

Total degrees of curvature in main road, :

Total degrees of curvature in branch roads,

Total length of straight line in main road, .

Total length of straight line in branches, .

Aggregate length of wooden truss bridges,

Aggregate length of all other wooden bridges,

Aggregate length of iron bridges, .

Whole length of road unfenced on both sides,

Number of public ways crossed at grade, .

Number of railroads crossed at grade,

Remarks,

Way stations for express train,

Way stations for accommodation trains,

$6,632-1,000$ miles.

66

66

3,20000

6,17534

23,43489

$\$ 251,25775$

20,90800

3,250 feet.

56 and 60 pounds.

56 feet and 89-1,000 miles.

$211-2=10$ feet rise.

\} $7-13-1,000$ in fall.

1,000 feet; 980 feet long.

405 feet.

4.232-1,000 miles.

80 feet.

None.

300 rods.

7

None.

None.

6 
Flag stations, . . . . . . . 4

Whole number of way stations, $\quad . \quad$. $\quad: 6$

Whole number of flag stations, $\quad$. $\quad .44$

\section{DoINGS DURING the Year.}

Miles run by passenger trains, . . . . . 15,006

Miles run by freight trains, $\quad . \quad \quad . \quad . \quad 567$

Miles run by other trains, . . . . .

Total miles run, Number of passengers carried in the cars, .

Number of passengers carried one mile,

Number of tons of merchandise carried in the cars,

Number of tons of merchandise carried one mile,

Number of passengers carried one mile, to and from other roads,

Number of tons carried one mile to and from other roads,

Rate of speed adopted for express passenger trains, including stops, .

Average rate of speed actually attained by express passenger trains, including stops and detentions,

Rate of speed adopted for accommodation trains,

Rate of speed actually attained by accommodation trains, including stops and detentions,

Average rate of speed actually attained by special trains, including stops and detentions,

Average rate of speed adopted for freight trains, including stops, . . . .

Estimated weight in tons of passenger cars (not including passengers), hauled one mile, .

Estimated weight in tons of merchandise cars (not including freight), hauled one mile,

\section{EXPENDITURES For WORKING THE ROAD.}

For repairs of road, maintenance of way, exclusive of wooden bridges, and renewals of iron,

For repairs of wooden bridges

For wages of switchmen, average per month, $\$ 30,30,26=86$,

For wages of gate-keepers, average per month, $\$$ month, $\$-$ of signal-men, average per
month, $\$$ - Total,

For wages of watchmen, average per month $\$$

Number of men employed exclusive of those engaged in construction,

For removing ice and snow, (this item to include all labor, tools, repairs, and extra steam-power used,)

For repairs of fences, gates, houses for signal-men, gate-keepers, switchmen, tool-houses,

20 miles.

16 “

$14 \quad 6$

No means of ascertaining.

15,573

107,735

458,087

24,992

60,488

429,062

52,622

Total for maintenance of way,

1,03200

12525

3000 


\section{Motive Power and Cars.}

For repairs of locomotives,

For new locomotives, to cover depreciation,

For repairs of passenger cars,

For new passenger cars, to cover depreciation,

For repairs of merchandise cars,

For new merchandise cars, to cover depreciation,

For repairs of gravel and other cars,

Total for maintenance of motive power and cars,

Number of engines,

Number of passenger cars,

Number of baggage cars, .

Number of merchandise cars,

Number of gravel cars,

\section{Miscellaneous.}

For fuel used by engines during the year, viz. :

Wood, number of cords, 250. Cost of the same, Coal, number of tons, (reckoning 2,240 lbs. to the ton, ) 100. Cost of the same,

For oil used by cars and engines,

For waste and other material for cleaning,

For salaries, wages and incidental expenses, chargeable to passenger department,

For salaries, wages and incidental expenses, chargeable to freight department,

For gratuities and damages,

For taxes and insurance, .

For ferries,

For repairs of station buildings, aqueducts, fixtures, furniture,

For renewals of iron, including laying down,

For new iron laid down, deducting the value of old iron taken up,

For amount paid other companies, in tolls for passengers and freight carried on their roads, specifying each company,

For amount paid other companies, as rent for use of their roads, specifying each company,

For new car house,

For salaries of president, treasurer, superintendent, law expenses, office expenses of the above offices, and all other expenses not included in any of the foregoing items,

Total Miscellaneous,

Total expenditures for working the road, .

Total amount of interest paid during the year,

\section{INCOME DURING THE YEAR.}

\section{For passengers :-}

1.- On main road, including branches owned by company,

2.-To and from other roads, specifying what,
$\$ 67494$

33826

7127

$\$ 1,08447$

$\$ 1,74474$

15725

2000

2,68543

3,30576

15850

49912

94105

1,336 49

10,84834

$\$ 15,48704$ 
For freight:-

1.- On main road and branches owned by com2.-To and from other connecting roads, U. S. mails, Rents,

Total income,

Net earnings, after deducting expenses,

\section{Dividends.}

3 per cent. Total, Surplus not divided, Surplus last year, Total Surplus,

Estimated Depreciation beyond the RenewALS, viz.:

Of road and bridges,

Building,

Engines and cars,

\section{Mortgage Debts.}

Amount of debts, secured by mortgage of road and franchise, or any property of the corporation, per last report,

Mortgage debt, paid since last report,

Increase of mortgage debt since last report,

Present amount of mortgage debt, .

Number of mortgages on road and franchise, or any property of the corporation, .

$\$ 6,391 \% 6$

43268

5000

$\$ 20,59881$

5,11177

$\$ 9,00000$

$\$ 20000$

5000

40000

CHARLES HUDSON,

SAMUEL BUTTERFIELD, JAMES DANA, ARTHUR T. LYMAN, ADDISON GAGE,

A. W. FARRAR, Divectors of the Railroad Corporation. 
Suffouk, ss. December 26, 1861 . Then personally appeared Samuel Butterfield, Addison Gage, Arthur T. Lyman, James Dana, A. W. Farrar, and severally made oath to the truth of the foregoing statement, by them subscribed, as true, according to the best of their knowledge and belief. Before

Chardes Hudson, Justice of the Peace throughout the State.

Sufrour, ss. December 26, 1861. Personally appeared Charles Hudson, and made oath that the within statement, by him subscribed, is true, according to his best knowledge and belief. Before me,

E. Pearson, Justice of the Peace. 


\title{
SIX'TEENTH ANNUAL REPORT
}

\author{
OF THE DIRECTORS OF THE
}

\section{Lowell and Lawrence Railroad Company,}

FOR THE YEAR ENDING NOVEMBER 30, 1861.

\author{
Capital Stock. \\ Number of shares of capital stock issued, \\ Incresse of capital since last report, \\ Capital pali in, per last report, \\ Capital paid in, since last report, \\ Total amount of capital stock paid in, \\ Funded debt, per last rejurt. \\ Funded debt, paid since last report, \\ Funded debt, increase of since last report, \\ Tutal present amount of runded debt. \\ Nloating debt, per last report, \\ Floating debt, paid since last report, \\ Floating detit, increase it, since lasf report, \\ Tutsl prisent amisunt of floatius debt, \\ Total present amount of fundesd anil Hoating debt, \\ Averagt rate of interest per annum, paid during the year, \\ Maximum amount of debts during the year. \\ Surplus-Contra, \\ Paid from earnings-Contra

\section{COST OF ROAD AND EQUIPMENT.}

For graduation and masonry, per list report,

For gralustion and masonry, pali during the past year.

Totil amoint expended fior graduation and masonry,

For wooden tridges, per last repo't,

For wooden tridges, paid during the past year.

Total annure afuended for wonden tridges,

Total am wuse sxiended for iron brldges (if any),

For superstructure, including iron, per last ruport,

For supesstructure, including lron, puid during the past year,

Tistal amount Axpended for'supe, s: ructure, including iron

For statims, buildings and fixtures, par last report,

For statious, building and fixtures paid during the past year,

Total amuunt $\mathrm{x}$ [mended for stations, buildings and fixtures,

For lani, lan i-danuges and Yences, per last report,

For land, land-lawnages nnd fonces, piaid during the past year,

Total amount expended for land, land-damages and fonces,

For lncomotives, per last report,

For lucomotives, paid during the past year.

Totil anount expended for locomutives.

For passenger aut laggage cars, per last report,

For jassenger and baggage cars, paid during the past year Total anount $\theta x$ pended for flassenger and baggage cars,

For marchandlse cars, per last report.

Fur merchandise cars, paid during the past year,

Tutal amount expended for murchantlise cars,

Finr enguneering, per last report.

For engineering, patd during the past year,

Total amount expended for engineering,

For asencies and other expenses, per last report.

For ugancies and other expenses, paid furing the past vaar,

Total amounc oxpended for agencies aud uther expenses,

\section{2,000 \\ None. \\ 200,00000 \\ None. \\ 75,00000 \\ None. \\ None. \\ 75,00000 \\ 19,91616 \\ 4,26119 \\ None \\ 15,65500 \\ 6 per cent. 97,65500 \\ 90,65500 \\ $\$ 300,00000$ \\ 200,00000 \\ 76.29727 \\ 366,95227}

77,51632

Nothing.

5,304 61

Nothing.

Nothing.

161,41637

Nothing.

15,108 I8

Nothing.

45,37881

Nothing.

15,15325

Nothing.

7,00060

Nothing.

8,12143

Nothing.

8,19783

Nothing.

21264

Nothing.

77,51692

3,30461

161,41637

15.10819

15,378 81

15,15325

7,00060

8,12148

8,19785

21264 
Balance of interest on loan during construction and paid stockholders,

Discount on bonds,

Total cost of road and equipment,

A mount of assets or property held by the corporation in addition to the cost of the road,
9,74805

10,00000

19,74805

$\$ 363,15812$

3,79415

8,79415

$\$ 366,95227$

\section{CHARACTERISTICS OF ROAD.}

Length of road,

Length of single main track,

Length of double main track,

Length of branches owned by the Company, stating whether they have a single or double track,

Aggregate length of sidings, and other tracks, excepting main tracks and branches,

Weight of rail, per yard, in main road,

Weight of rail, per yard, in branch roads, (specify the different weight per yard,)

Maximum grade, with its length, in main road,

Maximum grade, with its length, in branch roads,

Total rise and fall in main road,

Total rise and fall in branch roads,

Shortest radius of curvature, with length of curve, in main road,

Shortest radius of curvature, with length of curve, in branch roads,

Total degrees of curvature, in main road,

Total degrees of curvature in branch roads,

Total length of straight line, iu main road,

Total length of straight line, in branches,

Aggregate length of wooden truss bridges,

Aggregate length of all other wooden bridges,

Aggregate length of iron bridges,

Whole length of road unfenced on both sides,

Number of public ways crossed at grade,

Number of railroads crossed at grade,

Remarks,

Way stations for express trains,

Way stations for accommodation trains,

Flag stations,

Whole number of way stations,

Whole number of flag stations,

\section{DOATGS DURING THE YEAR.}

Miles run by passenger trains,

Miles run by freight trains,

Miles run by other trains,

Total miles run,

Number of passengers carried in the cars,

Number of passengers carried one mile,

Number of tons of merchandise carried in the cars,

Number of tons of merchandise carr:ed one mile,

Number of passengers carried one mile, to and from other roads,

Number of tons carried one mile, to and from other roads,

Nate of speed adonted for express passenger trains, including stops,

Average rate of speed actually attained by express passenger trains, including stops and detentions.

Rate of speed adopted for accommodation trains.

Rate of speed actually attained by accommodation trains, including stops and detentions.

Average rate of speed actually attained by special trains, including stops and detentions.

Average rate of speed adopted for freight trains, including stops. Estimated weight in tons of passenger cars (not including passeogers) hauled one mile,

Estimated weight in tons of merchandise cars (not including freight) hauled one mile,
12.35 miles

12.35 miles.

None.

None.

2 miles 1.500 feet.

$58 \mathrm{lbs}$.

45.40

None.

Rise,115.77; fall, 162.70.

None.

1.146 feet; length, 1,100 feet.

None.

$420^{\circ}$

None.

8.86 miles.

None.

None.

400 feet.

None.

All fenced or otherwise protected.

12

2

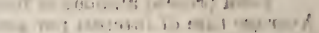

None.

None. _ itit it it?

5

None.

Operated by the Boston \& Lowell Railroad Corporation, under contract. A copy is annexed to the report of 1858.
None. 3()$^{\prime}$. 
EXPENDITURES FOR WORKING THE ROAD.

For repairs of road, maintenance of way, exclusive of wooden bridges, and renewals of iron,

For repairs of wooden bridges,

For wages of switchmen, average per month,

For wages of gate-keepers, average per month,

For wages of signal men, average per month,

For wages of watchmen, average per month, $\$$ engaged in con-

Number of

struction,

For removing ice and snow, (this item to

repairs, and extra steates, houses for signal-men, gate-keepers,

For repairs of fences, gates,

Total for maintenance of way,

\section{MOTIVE POWER AND CARS.}

For repairs of locomotives

For new locomotives, to cover depreciation,

For repairs of passenger cars,

For new passenger cars, to cover depreciation,

For repairs of merchandise cars,

For new merchandise cars, to cover depreciation,

For repairs of gravel and other cars,

Total for maintenance of motive power and cars,

Number of engines,

Number of passenger cars,

Number of baggage cars,

Number of merchandise cars,

Number of gravel cars,

\section{MISCELLANEOUS.}

For fuel used by engines during the year, viz:-

Wood, number of cords. Cost of the same,

Coal, number of tons, (reckoning 2,240 lbs. to the ton.) Cost of same,

For oil used by cars and engines,

For waste and other material for cleaning,

For salaries, wages, and incidental expenses, chargeable to passenger department,

For salaries, wages, and incidental expenses, chargeable to freight department,

For gratuities and damages,

For taxes and insurance,

For ferries,

For repairs of station bulldings, aqueducts, fixtures, furniture

For renewals of iron, including laying down,

For new iron laid down, deducting the value of old iron taken up

For a mount paid other companies, in tolls for passengers and

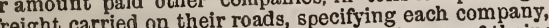

For amount paid other companies, as rent for use of their roads, specifying each company,

salaries of president, treasurer, superintendent, law expenters and all other pexpes, office not included in any of the foregoing items,

Tutal miscellaneous,

Total expenditures,

Total amount of interest paid during the year,

Total expense and interest,

\section{INCOME DURING THE YEAR.}

For Passengers :-

On main road, including branches owned by company,

1. To and from other roads, suecifying what,

For Freight:-

On main road and branches owned by company,

1. To and from other connecting roads,

U. S. Mails,

Rents

Total income,

Net earnings after deducting expenses,
Paid by Boston \& Lowell Railroad Corporation.

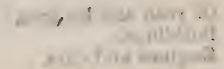

$\int+1+1$

Run by Boston \& Lowell Rallroad Corporation.

Railroad Corporation.

26994

18016

45010

45010

5,50083

$\$ 5,95093$

Operated by Boston and Lowell Railroad Corporation under contract, who pay six per cent. on 363,00000 
6 Per cent. Total,

Surplus not divided,

Surplus last year,

Total surplus,

ESTIMATED DEPRECIATION BEYOND THE RENEW-

Of road and bridges,

DIVIDENDS.

Buildings,

Engines and cars,

ALs, viz. :

\section{MORTGAGE DEBTS.}

Amuunt of debts secured by mortgage of road and franchise, or any property of the corporation, per last report,

Mortgage debt paid since last report,

Incresse of mortgage debt since last report.

Present amount if mortgage debts, siumber of mortgages on road and franchise, or any property of
the corporation,

Sidnex Spalding, A. W. Buttrick, IsAaC FarRington, Otis Allen,

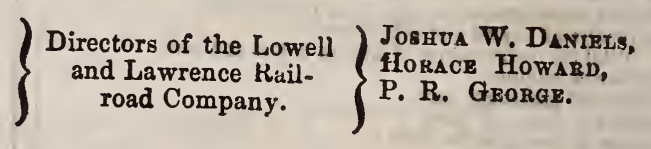

Mrdndesex, ss - Then personally appeared Sidney Spalding, A. W. Buttrick, Isaac Farrington, Otis Allen, Joshua W. Daniels, Horace Howard, and P. $\boldsymbol{R}_{\text {. }}$ George, and severally made oath to the truth of the foregoing statement by them subscribed, according to their best knowledge and belief. Before

Luwzex, December 9, 1861.

F. H. NOURSE, Justice of the Peace. 


\section{REPORT OF THE DIRECTORS}

OF THE

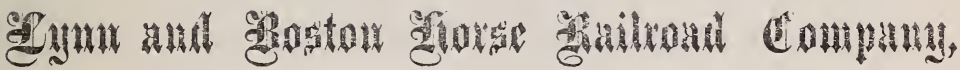

For the Year ending November 30, 1861.

\section{Cundition of the Company.}

Capital Stock, fixed by charter,

Capital Stock, as voted by the Company,

$\$ 200,000 \quad 00$ $100,000 \quad 00$

Capital Stock, paid in, in cash,

$39,800 \quad 00$

Capital Stock, paid in, in work and materials,

by contractors and others,

$43,500 \cdot 00$

Funded debt,

Floating debt,

$37,500 \quad 00$

43,02386

Total debt, 80,52386

Amount above debt secured by mortgage of the road and franchise, or any property belonging to the Corporation, or standing in its name,

Number of mortgages on road and franchise, or any property of the Corporation, specifying the number and amount of mortgages on road and franchise, and each kind of property, One Mortgage on road.

Amount of assets on hand, exclusive of the road and equipment, and exclusive of all property on hand, used, or which is to be used, in running the road and keeping it in 
A mount expended for lubor in excavating for the track, laying foundation and rails, Amount expended for timber for fonndation, Amount expended for iron and other metal for rails, chairs, spikes, or other articles, ased in building the road,

Amount expended for paving,

A mount expended for paving stones,

Amount expended for engineering,

Amount expented for interest, salaries of officers during construction of road, and other expenses not included in any of the above items, which have been included, on the books of the Company, in the cost of the road, not including items of equipment or running expenses, as mentioned below, 'T'otal cost of road,

- Amount included in the present and in past years, among the running expenses for estimated or actual depreciation of the road, Net cost of road,

\section{Cost of Equipment.}

No. of cars and cost-21 cars, $\$ 700$ each

No. of horses and cost-61 horses, \$112.50 each, Cost of omnibuses, sleighs, and other vehicles, excepting cars, owned by the Company,

Cost of land, and buildings thereon when purchased,

Cost of buildings used for offices, stables, \&c., erected by the Company, or standing on lind not owned by the Company,

Cost of other articles of equipments, (specifying what)

10 sets car-wheels and axles, 
142 collars, $\$ 42600$

33 sets harnesses, extra reins, \&c.,

90 blankets, 1,19000

18000

Furniture in office, blacksmith's tools, and articles in stables,

85324

Total cost of equipment, 41,27174

Amount included in the present and in past years in the running expenses for estimated or actual depreciation of any of the above items,

Net amount at which the cquipment stands charged on the books of the Company,

Characteristics of the Poad.

Length of single main track, $11 \frac{1}{2}$ miles. Length of double main track,

Total length of road,

Length of branches owned by the Company, stating whether they have a single or double track,

Aggregate length of switches, sidings, turnouts, and other track, excepting main track and branches,

Total length of rail,

Weight of rail used, per yard, (specifying whether of cast or rolled iron)

3000 feet.

About $12 \frac{1}{4}$ miles.

Maximum grade per mile on road, with length

of grade,

Shortest radius of curvature, with length of curve,

Greatest length of single track on road between two turnouts,

Total length of main track which is paved,

About 1 mile.

Doings During the Year.

Total number of miles run during the year, 
$N_{\text {L . . . u }}$ passengers carried in the cars,

Rate of speed adopted, includ ng stops and detentions,

Rate of speed actually attained, including stops and detentions,

Number of persons employed regulaly, (specifying the occupations of each, )-1 treasurer, 1 clerk, 1 superintendent, 17 conductors, 17 drivers. 2 painters, 1 cabinet maker, 3 blacksmiths, 2 ferrymen, 21 men in stables,

66 men.

Total number of trips run during the year, Average number of passengers each trip,

7 miles per hour.

7 miles per hour.

12,328

$20 \frac{1}{2}$

Expenditures for Working the Road.

For repairs of road, including repairs of foundation, renewals of iron, and renewals of pavements,

For general repairs, including repairs of cars, omnibusses, aud harnesses, and for shoeing horses,

For repairs of real estate, including repairs of building used as stables, offices, or for any other purposes by the Company,

For wages, including the wages of every person regularly employed, excepting the President, Directors, Superintendent, and Treasurer,

For interest,

I'or taxes and insurance,

For tolls paid other companies, for the right to pass over their roads,

For rent paid other companies for use of their roads, 
s.: p.viner,-to include cost of hay, grain, straw, and other articles used for food and bedding of horses,

For miscellaneous articles purchased during the year-such as harnesses, blankets, \&c., the use of which continues for one or more years - and not included in the cost of equipment,

For loss on horses - that is to say, the difference between the present estimated value of the horses owned by the Company, subtracted from the estimated value of those on hand at the commencement of the year, added to the cost of those purchased during the year; or if this is the first report of the Company, then the difference between the estimated value of the horses on hand and their cost-giving the present estimated value of each horse,

For incidental expenses,- to include printing, President's, Directors', Treasurer's, and Superintendent's salaries, and all expenses other than those belonging to the actual working of the road,

For all other expenses,

For amount charged on the Company's books, during the ye.r, for estimated or actual depreciation of the following property :-

Cars,

Horses,

Omnibuses,

Real Fistate.

Road,

Other property,

Total,

Total expenses, 


\section{Earnings.}

Received from passengers in cars and omnibuses, and for tickets sold,

From other roads, as toll or rent for use of road,

From United tates mails,

1250

For sales of manure,

From other sources,

Total earnings,

Net earnings, after deducting expenses.

Surplus earnings of previous year on hand,

Net earnings, as above,

Total surplus for payment of dividends,

Dividends declared during the year,

Total percentage of dividends for the year,

Present surplus,

\section{Miscellaneous.}

Increase during the year-

Of capital stock, as fixed by the charter,

Of capital stock, as voted by the Company,

Of capital stock, paid in.

Increase of funded debt, during the year, Increase of floating debt, during the year, Decrease of funded debt, during the year, Decrease of flonting debt, during the year, Increase of mortgage debt, during the year, Decrease of mortgage debt, during the year, Increase in cost of road, during the year, including amount charged for depreciation thereon,

Decrease in nominal cost of road, by amount charged for depreciation thereon,

Increase in cost of equipment, during the year, including amount charged for depreciation thereon, 
Decrease in cost of equipment, by the sale of any portion thereof, or by amount charged for depreciation,

List of Accidents on the Road during the Year.

One man slightly injured.

One boy do. do.

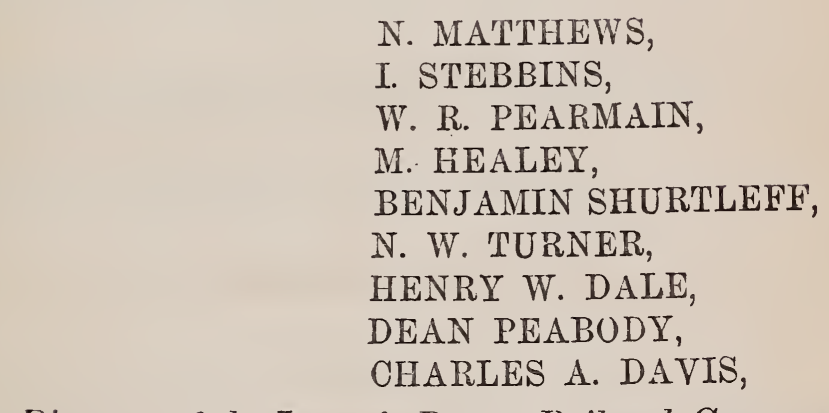

Directors of the Lynn \&. Boston Railroad Company.

SuFfolk, ss. December 18, 1861.

Then personally appeared N. Matthews, I. Stebbins, W. R. Pearmain, Mark Healey, Benj. Shurtleff, N. W. Turner, Henry W. Dale, Dean Peabody, and Charles A. Davis, and severally made oath to the truth of the foregoing statement by them subscribed.

Before me,

WM. A. WILLIAMSON,

- Justice of the Peace. 



\section{R E P O R T}

or THE

\section{R E C T O R $\mathbf{S}$}

\section{OF THE MARLBOROUGH AND FELTONVILLE BRANCH RAILROAD CORPORATION.}

\section{For the Year Ending November 30, 1861.}

1. Capital Stock,

$\$ 27,500$

2. Number of shares of capital stock issued, ......_._..._._._- 275

3. In rrease of capital, since last Report, None.

4. Capital paid in, per last Report. $\$ 27.500$

5. Capital paid in, since last Report._._._._._._._._. None.

6. Total amount of capital stock paid in,

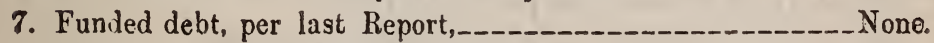

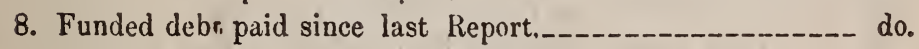

9. Funded debt, increase of, since last Report,_-______._._. do.

10. Total present amount of funded debt,_............- do.

11. Floating deht, per last Report._........................ do.

12. Flouting debt paid since last Report._._._._._._._._..... do.

13. Floating debt, increase of, since last Report,_._._._..... do.

14. Total present arnount of fluating debt,.............. do.

15. Total present amount of funded and floating debt,-.-- do.

16. Average rate of intercst per annum, paid during the year,... dn.

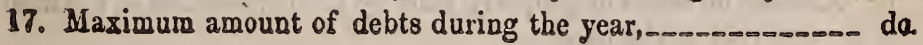




\section{COST OF ROAD AND EQUIPMEN'T.}

13. For griduation and masonry, per last Report.

19. For gradustion and $m$ isonry, paid during the past year.

20. T'utal amount expended for graduation and masonry.

21. For wonten brilges per last Report.

22. For wood n bridges, paid during the past year.

23. 'Total amonnt expended for wooden bridges.

24. Toial annunt expended for iron bridges (if any).

2.). For superstructure, induding iron, per last Report.

23. For superstructure, in sluding irun. paid during the past year.

27. ['utal a a cut expendel for saperstrueture. including iron.

8 23. Fur stations, buillings and fixtures, per last Report.

29. For stations, buidinges and fixtures, paid during the past ycar.

5. I. I otal aununt expended for stations, liniadings and fixtures

31. For land, land damages aid fonces per last Report.

32. For land land-inminges and fences, paid diring the past year.

33. Total amount expended for land, land-damages and fences

3 t. For losomitives. per last Report.

35. For locomotives, puid during the past year.

36. T'otal a llourit expended for leconotires.

37. For passenger and baygage cars, per last Report.

33. For passenger and bagrgage cars, paid during the past year.

39. Total amomnt expended for passenger and baggage cars.

40. For merchanelise curs, per last Report.

41. For merchondise curs, paid during the past year.

42. 'intal amount expended for merchancise cars.

4\%. For engineering, per last Repurt.

4t. For engineering. paid during t e past year.

45. Tutal anount expended for cngincering.

46. For agencies and oiher expenses, per last Report.

47. Fur agencies and other expeuses, paid during the past jear.

43. Total anount expcnded for agencies and other expenses.

49. Total cost of road and equipment.

50. Amsunt of assets or property held by the corporation in addition to the cost of the road. 


\section{CHARACTERISIICS OF ROAD.}

61. Tength of road,

52. Length of single main track.

53. Length of double main truck, ._._._._._. . . _._._._. Nine.

54. Length of branches owned by the Compiny, stating whetliet they have a single or double track,._................ do.

65. Aggregate kength of sidings, aud other tracks, excepting main track and branuhes....................... dn.

66. Weight of rail, per yard, in main road,.............. 52 lbs

57. Weight of ruil, per pard, in biandh roads, (specify the different weights per yard, ) _............. 2 lba

8. Naximum grade, with its length, in main road......... $97 \mathrm{ft}$ per mile for 3200 fto

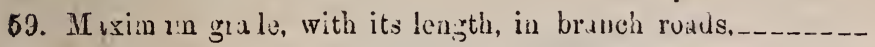

60. Total rise and fall in maiu road. 47 ft. per mile for $: 200 \mathrm{ft}$

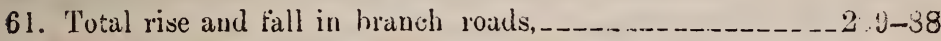

62. Shortest radius of curvature, with length of curve. in main road, -

63. Shortest radius of curvature, with length of curve, in bratuch

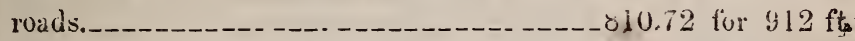
64. Total degrees of eurvature, in wain ruad....._._. $649=y^{\prime} 3^{\prime \prime}$

65. Total degrees of eurvature, in brandh rouds,..._._._. $549^{\circ} 9^{\prime} 3^{\prime \prime}$ 66. Total leugth of straight line, in maiu road. : 010.10 t.t., in ail $1 \frac{1}{2}$ miles

67. Total length of straight line, iu brauches. i 010.10 tt., in ail $1 \frac{1}{2}$ wiles 68. Aggregate len rth of wooden triss bridges, 69. Aggregate iength of all other wouden bridges._-_._._._. 194 f 70. Aggregate length of iron bridges, 71. Whole length of road unfenced on both sines,

72. Nurnber of public ways crusscu at grade, _. -

73. Number of raiiroads crossed at grade,

74. liemarks,

75. Way stations for express truins,

76. Way stations for accommodation trains,

77. Flug stations,

78. Whole number of way stations

79. Whole number of Hag stations, 


\section{DOINAS DURING THE YEAR.}

80. Miles run by passenger trains.

81. Miles run by freight trains.

82. Miles run by other trains.

83. Total miles run.

84. Number of passengers carried in the cars.

85. Number of passengers carried one mile.

86. Number of tous of merchandise carried in the cars.

87. Number of tons of merchandise carried one mile.

88. Number of passengers carried one mile, to and from other road.

89. Number of tons carried one mile, to and from other roadis.

90. Rite of spzed alopted for express passenger trains, including stope.

91. Average rate of speed actually attained by express passenger trains, including stops and detentions.

92. Rate of speed adopted for accommodation trains.

93. Rate of speed actually attained by accominoration trains, including stops and detentions.

94. A verage rate of speed actually attained by special trains, including stops and detentions.

95. Average rate of speed adopted for freight trains, including stops.

96. Estimated weight in tons of passenger cars (not including pasengers) hauled onc mile.

97. Estimated weight in tons of merchandise cars (not including freight) hauled one mile.

\section{EXPENDITURES FOR WORKING THE ROAD.}

98. For repairs of road, maintenance of way, exclusive of pooden bridges, and renewals of iron.

99. For repairs of wooden bridges.

100. For wages of switchmen, average per month,

101. For wages of gate-keepers, average per month,

102. For wages of signal-men, average per month,

103. For wages of watchmen, average per month,

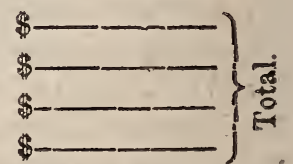

101. Number of men employed, exclusive of those engaged in construction.

105. For removing ice and snow, (this item to include all labor, tools, repairs, and extra steam-power used.)

103. For repairs of fences, gates, houses for signal-men, gate-keepera. switchmen, tool-houses.

107. Total for maintenance of way. 


\section{MOTIVE POWER AND CARS.}

108. For repairs of locomotives.

109. For new locomotives, to cover depreciation.

110. For repairs of passenger cars.

111. For new passenger cars, to cover depreciation.

112. For repairs of merchandise cars.

113. For new merchandise cars, to cover depreciation.

114. For repairs of gravel and other cars.

115. Total for maintenance of motive power and esra.

116. Number of engines.

117. Number of passenger cars.

118. Number of baggage cars.

119. Number of merchandise cars.

120. Number of gravel cars,

\section{MISCELLANEOUS.}

121. For fuel used by engines during the year, viz. :-

1. Wood, number of cords._ Cost of the same.

2. Coal, number of tons, (reckoning 2,240 lbs. to the ton, ) Cost of same.

122. For oil used by cars and engines.

123. For waste and other material for cleaning.

124. For saluries, wages and incidental expenses, chargeable to passenger department.

125. For salaries, wages and incidental expenses, chargeable to freight department.

126. For gratuities and damages.

127. For taxes and insurance.

128. For ferries.

129. For repairs of station buildings, acqueducts, fixtures, furniture.

130. For renewals of iron, including laying down.

131. For new iron laid down, deducting the value of old iron taken up.

132. For amount paid other companies, in toll's for passengers and freight carried on their roads, specifying each company.

133. For amount paid other companies, as rent for use of their roads, specifying each company.

134. For salaries of president, treasurer, superintendent, law expenses, oftice expenses of the above offices, and all other expenses not included in any of the foregoing items, ................ \$467 41

135. Total Mliscellaneous. 
- Miscellaneous (Continced.)

135. Total expenditures for working the road. , Reported by the 137. T'utal amount of interest paid during the year. $\}$ Fitchburg R. B. Co.

INCOME DURING THE YEAR.

138 For Passongers :-

1. On min road, including branches owned by company.

2. To and from other rouds, specifying what.

139. For Freight:-

1. Ou main road and branches owned by company.

2. 'To and from other connecting roads.

140. U. S. Hails.

141. lients.

14.) T'otal income, $\$ 2,534$ :

143. Net earuings ufter deductiug expenses,

DIVIDENDS.

144. Per cent. Total,_-_-__-__-_ \$1,650 00

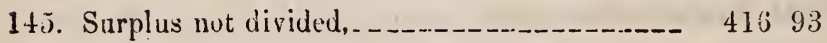

146. Surplus last year,-_-_-_-_-_-_-_-_-_-_ 5133

I47. Total surpius, _-_..._._.

ESTIMATED DEPREGATION BEYOND THE RENEWALS, Vaz:

143. Of roads and bridges ? Reported by the

149. Buildings.

150. Engines and cars.

Fitchburg Railruad Company.

\section{MORIGAGE DEBT'S.}

151. Amount of debts secured by mortgage of road and franchise, of any property of the Cerpuration, per last Repurt,

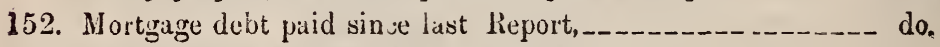

153. Increase of mortgage dent since last Report,_._________-_ do.

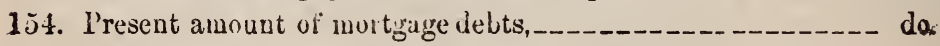

155. Number of mintgages on road and franolise, or any property of Curroration.

LAMBER [ BIGLLOW, )

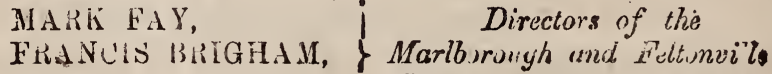
T. M. MLLES, ivil. E. bisfuidad, 
MrddLISEx, 8s., December 24, 1861.

Then personally appearod Lambert Bigelow, Mark Fat, Fraxois Brigham, T. M. Miles, and WM. E. BrighaM, and severally made oath to the truth of the foregoing statement by them subscribed.
BuFORE:
O. W. ALBEE, Justice of the Peace 



\section{ANNUAL REPORT}

O F T H E

\section{MALDEN AND MELROSE RAILROAD}

TO $\mathrm{T}$ H $\mathrm{E}$

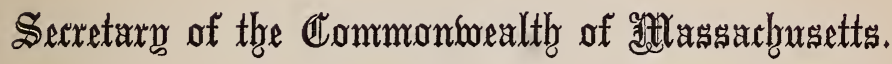

FOR THE YEAR ENDING NOVEMBER 30th, 1861.

CHARLESTOWN :

$\begin{array}{llll}\text { PRINTED } & \text { BY } & \text { W. W. WHEILDON. }\end{array}$

1861 . 

OF THE

\section{MALDEN AND MELROSE RAILROAD COMPANY.}

For the Year ending November 30 th, 1861.

Report of the Directors of the Malden and Melrose Railroad Company, under General Statutes, Chapter 68. Sects. 148, 144.

CoNdition OF THE COMPANY.

Capital stock, fixed by charter, -

Capital stock, as voted by the company,

Capital stock paid in, in cash, - - -

Capital stock paid in, in work and materials, by contractors and others, - $\quad$ - $\quad$ -

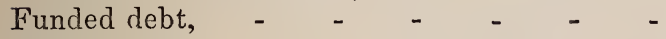

Floating debt, - $\quad-\quad$ - $\quad$ - $\quad$ -

Total debt, - $\quad$ - $\quad$ - $\quad$ -

Amount of above debt secured by mortgage of the road and franchise, or any property belonging to the corporation, or standing in its name,

Number of mortgages on road and franchise, or any property of the corporation, specifying the number and amount of mortgages on road and franchise, and each kind of property,

Amount of assets on hand, exclusive of the road and equipment, and exclusive of all property on hand, used, or which is to be used, in running the road and keeping it in repair,

\section{Cost of the Road.}

Amount expended for labor in excavating for the track, laying foundations and rails,

Amount expended in timber for foundation, -

Amount expended for iron and other metal for rails, chairs, spikes, or other articles, used in building the road,

Amount expended for paving

Amount expended for paving stones, - -

Amount expended for engineering, - -

Amount expended for interest, salaries of officers during construction of road, and other expenses not included in any of the above items, which have been included, on the books of the company, in the cost of the road, not including items of equipment or running expenses, as mentioned below,

Total cost of road, - $\quad$ - $\quad$ -

Amount included in the present and in past years, among the running expenses for estimated or actual depreciation of the road, -
$73,100 \quad 00$

$\$ 200,000 \quad 00$

$200,000 \quad 00$

$165,000 \quad 00$

55,18673

$128,286 \quad 73$

$*$

99,52323

The Road was built by contract, and it is impossible for the Directors to state the cost of the different items.

60,20046

Nothing.

* There are four mortgages - one for $\$ 15,000$ on Road to secure bonds, of which $\$ 14,700$ are issued; one for $\$ 60,000$ on road, franchise and equipment, to secure bonds of which, $\$ 58,400$ have been issued; one to secure $\$ 1,21040$, and one to secure $\$ \$ 4000$. The last two are on real estate owned by the Company. 


\section{Cost of Equipment.}

Number of cars and cost, - $\quad$ - $\quad$ - 42 Number of horses and cost, - $\quad-\quad-277$ Cost of omnibuses, sleighs and other vehicles, excepting cars, owned by the company,

Cost of land and buildings thereon when purchased,

Cost of buildings used for offices, stables, \&c., erected by the company, or standing on land not owned by the company,

Cost of other articles of equipment, (specifying what,)

Total cost of equipment, - $\quad$ - $\quad$ -

Amount included in the present and in past years in the running expenses for estimated or actual depreciation of any of the above items,

Net amount at which the equipment stands charged on the books of the company,

\section{Characteristics of the Road.}

Length of single main track,

Length of double main track,

Total length of road, - _ _ _ -

Length of branches owned by the company, stating whether they have a single or double track,

Aggregate length of switches, sidings, turnouts and other track, excepting main track and branches,

Total length of rail, - $\quad$ - $\quad$ - $\quad$ -

Weight of rail used, per yard, (specifying whether of cast or rolled iron,)

Maximum grade, per mile on road, with length of grade,

Shortest radius of curvature, with length of curve,

Greatest length of single track on road between two turnouts, -

Total length of main track which is paved, -

\section{DoINgs DURING the Year.}

Total number of miles run during the year, Number of passengers carried in the cars, Rate of speed adopted, including stops and detentions,

Rate of speed actually attained, including stops and detentions,

Number of persons employed, regularly, (specifying the occupations of each,)

Total number of trips run during the year, -

Average number of passengers each trip,
$34,216 \quad 75$

34,62500

11,73666

8,93391

8,04435

130,65081 Note A. 228,20748

Kept equal in value by charging to expense the repairs and loss.

228,20748

18,006 feet.

None.

18,006 feet.

None.

1,000 feet.

19,006 feet.

33,45 and $55 \frac{1}{4} \mathrm{lbs}$.

Rolled iron.

5 feet for $100 \mathrm{ft}$. or 264 feet per mile at Bayley's Hill.

70 feet radius, $110 \mathrm{ft}$. lgth. at Malden Cen. $60 \mathrm{ft}$. radius, cor. of Main and Alford sts. Charlestown.

About 6,000 feet. 603,951 $2,944,146$

8 miles.

7 miles.

See Note B. 89,531

$32 \frac{88}{100}$ 
EXPENDITURES For Working tHe RoAd.

For repairs of road, including repairs of foundation, renewals of iron, and renewals of pavement,

For general repairs, including repairs of cars, omnibuses and harnesses, and for shoeing horses, - - - - - - -

For repairs of real estate, including repairs of buildings used as stables, offices, or for any other purposes, by the company,

For wages, including the wages of every person regularly employed, excepting the president, directors, superintendent and treasurer,

For interest and coupons, - $\quad-\quad-\quad$ -

For taxes and insurance, - $\quad$ - $\quad$ -

For tolls paid other companies for the right to pass over their roads,

For rent paid other companies for use of their roads,

For provender, - to include cost of hay, grain, straw, or other articles used for the food or bedding of horses,

For miscellaneous articles purchased during the year - such as harnesses, blankets, \&c., the use of which continues for one or more years - and not included in the cost of equipment,

For loss on horses - that is to say, the difference between the present estimated value of the horses owned by the company subtracted from the estimated value of those on hand at the commencement of the year, added to the cost of those purchased during the year; or if this is the first report of the company, then the difference between the estimated value of the horses on hand and their cost - giving the present av. estimated value of each horse,

For incidental expenses, - to include printing, president's, directors', treasurer's and superintendent's salaries, and all expenses other than those belonging to the actual working of the road,

For all other expenses, including tolls, - -

For amount charged on the company's books during the year, for estimated or actual depreciation of the following property: -

Cars,

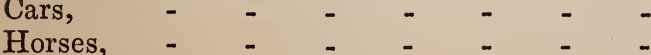

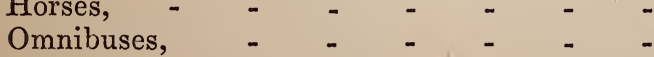

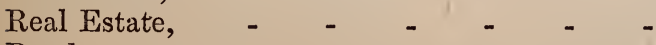

Road,

Other property,

Total,

Total expenses, -
1,50041

3,82289

66221

51,66983

$15,769 \quad 05$

1,30222

28,44550 Middlesex

5,62700 Chelsea.

1,45833 Somerville

6,622 30 Medford.

80000 Clift'dale.

$29,045 \quad 18$

Charged elsewhere.

2,66350

$11,604 \quad 16$

$8,345 \quad 80$

The values of these are kept equal by charging repairs and renewals to expense account. 


\section{EARnings.}

Received from passengers in cars and omnibuses, and for tickets sold,

From other roads, as toll or rent for use of road, From United States mails, - $\quad$ - $\quad$ -

For sales of manure, - $\quad$ - $\quad$ - $\quad$ -

From other sources, - $\quad$ - $\quad$ - $\quad$ -

Total earnings, - $\quad$ - $\quad$ - $\quad$ - $\quad$ -

Net earnings, after deducting expenses, -

Surplus earnings of previous year, - -

Net earnings, as above, - - - -

Total surplus for payment of dividends, -

Dividends declared, during the year, - -

Total per centage of dividends, for the year, -

Present surplus, after payment of dividends, -

\section{Miscellaneous.}

Increase during the year -

Of capital stock, as fixed by the charter, -

Of capital stock, as voted by the company, Of capital stock, paid in,

Increase of funded debt, during the year,

Increase of floating debt, during the year,

Decrease of funded debt, during the year, -

Decrease of floating debt, during the year, -

Increase of mortgage debt, during the year, -

Decrease of mortgage debt, during the year, -

Increase in cost of road, during the year, including amount charged for depreciation thereon,

Decrease in nominal cost of road, by amount charged for depreciation thereon,

Increase in cost of equipment, during the year, including amount charged for depreciation thereon,

Decrease in cost of equipment, by sale of any portion thereof, or by amount charged for depreciation,

\section{List of Accidents on Road, during the year.}

April 27 th. - A little boy, two years old, run under a car, while in motion, his leg was crushed by the wheel, and required amputation.
152,27229

Included elsewhere.

2846

1,65500

$19,767 \quad 50$

4,38487

$9,052 \quad 94$

4,38487

13,43781

Two.

43781

Nothing.

$5,800 \quad 00$

13,27212

Nothing.

2,29020

Net incr. per books, 2,04342

\section{DIREOTORS=}

WM. J. EAMES.

GEO. A. WHITING.

CHAS. E. POWERS.

WM. A. RICHARDSON.
J. E. M. GILLEY.

GRINFILL BLAKE.

JOHN H. BLAKE.

E. F. HODGES.

GEO. W. PALMER. 


\section{COMMONWEALTH OF MATSACHUSETTS.}

SUFFoLK, ss.

Boston, December 28, 1861.

Then personally appeared the above named Eames, Powers, Gilley, Whiting, and Hodges, and severally made oath that the foregoing statement, by them subscribed, is true, to the best of their knowledge and belief.

Before me,

L. M. CHILD, Justice of the Peace.

NOTE A.

Office, stable, shop, car, and road furniture - harnesses, snow ploughs, \&c., \&c., $\quad$ - $\quad$ - $\quad$ - $\quad$ - $\quad$ - $\quad$ - $\quad$ - 13,65081

Extension of Middlesex Road in Charlestown and Boston, switches and turnouts, the lease of the Middlesex, Somerville, and Medford Railroads, for the unexpired time of their Charters, with privileges purchased by this Company, 117,00000

NOTE B.

1 President.

1 Treasurer.

1 Managing Director.

1 Superintendent.

3 Clerks.

6 Overseers of stables.

29 Conductors.

30 Car drivers.

3 Shifters.
3 Mechanics - (car shop.)

2 Painters.

5 Blacksmiths.

6 Watchmen.

21 Hostlers.

2 Switchmen.

3 Roadmen.

1 Harness maker.

2 Flag men.

1 Harness cleaner.

121 Regularly employed in November, 1861. 



\title{
S E C O N D
}

\section{ANNUAL REPORT}

OF THE

\section{MEDFORD AND CHARLESTOWN RAILROAD}

\author{
т о т н Е
}

Secretary of the commonwealth of and assatbusetts.

FOR THE YEAR ENDING NOVEMBER 30th, 1861.

\section{CHARLESTOWN :}

PRINTED BY W. W. WHEILDON. 

OF THE

\section{MEDFORD AND CHARLESTOWN RAILROAD CO.}

For the Year ending November 30th, 1861.

Report of the Directors of the Medford and Charlestown Railroad Company, under General Statutes, Chapter 63. Sects. 143, 144.

\section{Condition of the Compant.}

Capital stock, fixed by charter, -

Capital stock, as voted by the company,

Capital stock paid in, in cash,

Capital stock paid in, in work and materials, by contractors and others,

Funded debt,

Floating debt,

Total debt,

Amount of above debt secured by mortgage of the road and franchise, or any property belonging to the corporation, or standing in its name,

Number of mortgages on road and franchise, or any property of the corporation, specifying the number and amount of mortgages on road and franchise, and each kind of property,

Amount of assets on hand, exclusive of the road and equipment, and exclusive of all property on hand, used, or which is to be used, in running the road and keeping it in repair

Cost of the Road.

Amount expended for labor in excavating for the track, laying foundations and rails,

Amount expended in timber for foundation, -

Amount expended for iron and other metal for rails, chairs, spikes, or other articles, used in building the road,

Amount expended for paving,

Amount expended for paving stones, - -

Amount expended for engineering, - -

Amount expended for interest, salaries of officers during construction of road, and other expenses not included in any of the above items, which have been included, on the books of the company, in the cost of the road, not including items of equipment or running expenses, as mentioned below,

Total cost of road,

Amount included in the present and in past years, among the running expenses for estimated or actual depreciation of the road, -

Net cost of road,
$\$ 200,000$

25,000

4,250

\section{7,750}

This Corporation now holds the entire road from Charles'wn line to Medford square. That part of the road from Charlestown line to the top of Winter Hill in Somerville is held under a perpetual lease from the Somerville Horse Railroad Company by whom it was constructed.

There is one mortgage for $\$ 12,000$, on that part of the road in the town of Somerville.

That part of the road from Medford square to the top of Winter Hill was built by contract and cost $\$ 22,000$. The cost of Winter Hill Branch was $\$ 12,000,-$ paid in bonds secured by mortgage, making the whole cost of the road $\$ 34,000$. 


\section{Cost of Equipment.}

Number of cars and cost, Number of horses and cost,

Cost of omnibuses, sleighs and other vehicles, excepting cars, owned by the company,

Cost of land and buildings thereon when purchased, -

Cost of buildings used for offices, stables, \&c., erected by the company, or standing on land not owned by the company,

Cost of other articles of equipment, (specifying what,)

Total cost of equipment, - $\quad$ - $\quad$ -

Amount included in the present and in past years in the running expenses for estimated or actual depreciation of any of the above items,

Net amount at which the equipment stands charged on the books of the company,

Characteristics of the Road.

Length of single main track,

Length of double main track,

Total length of road, -

Length of branches owned by the company, stating whether they have a single or double track,

Aggregate length of switches, sidings, turnouts and other track, excepting main track and branches,

Total length of rail

Weight of rail used, per yard, (specifying whether of cast or rolled iron,)

Maximum grade, per mile on road, with length of grade,

Shortest radius of curvature, with length of curve,

Greatest length of single track on road between two turnouts, - - - - - -

Total length of main track which is paved, -

DoIngs DuRING the Year.

Total number of miles run during the year, -

Number of passengers carried in the cars, -

Rate of speed adopted, including stops and detentions,

Rate of speed actually attained, including stops and detentions,

Number of persons employed, regularly, (specifying the occupations of each,)

Total number of trips run during the year, -

Average number of passengers each trip,
The road is equipped and run by Lessee.

The Corporation have no information as to the cost.

15,658 feet.

None.

15,658 feet.

None.

\section{1,386 feet.}

34,088 '6

7 All rolled, 13,554 ft. at 28 lbs. per yd.$18,172 \mathrm{ft}$. at $33 \mathrm{lbs}$. per yd., $2,372 \mathrm{ft}$. at 45 lbs. per yd.

242 feet in 936 feet ) 200 feet radius and 96 feet length of curve.

2,800 feet. 1,186 '6

The road being leased for a term of years it is impossible for the Corporation to answer. 
EXPENDITURES FOR Working the ROAD.

For repairs of road, including repairs of foundation, renewals of iron, and renewals of pavement,

For general repairs, including repairs of cars, omnibuses and harnesses, and for shoeing horses,

For repairs of real estate, including repairs of buildings used as stables, offices, or for any other purposes, by the company,

For wages, including the wages of every person regularly employed, excepting the president, directors, superintendent and treasurer,

For interest,

For taxes and insurance, - $\quad$ - _ -

For tolls paid other companies for the right to pass over their roads,

For rent paid other companies for use of their roads,

For provender, - to include cost of hay, grain, straw, or other articles used for the food or bedding of horses,

For miscellaneous articles purchased during the year - such as harnesses, blankets, \&c., the use of which continues for one or more years - and not included in the cost of equipment,

For loss on horses - that is to say, the difference between the present estimated value of the horses owned by the company subtracted from the estimated value of those on hand at the commencement of the year, added to the cost of those purchased during the year; or if this is the first report of the company, then the difference between the estimated value of the horses on hand and their cost - giving the present av. estimated value of each horse,

For incidental expenses, - to include printing, president's, directors', treasurer's and superintendent's salaries, and all expenses other than those belonging to the actual working of the road,

For all other expenses, - - - -

For amount charged on the company's books during the year, for estimated or actual deCars, preciation of the following property:-

Horses

Omnibuses,

Real Estate,

Road,

Other property,

Total,

Total expenses,
All expenses for repairs and working the road are paid by the Lessee. 


\section{EARNings.}

Received from passengers in cars and omnibuses, and for tickets sold,

From other roads, as toll or rent for use of road, From United States mails,

For sales of manure, -

From other sources, -

Total earnings, - $\quad$ - $\quad$ - $\quad$ - $\quad$ -

Net earnings, after deducting expenses, -

Surplus earnings of previous year, on hand, -

Net earnings, as above,

Total surplus for payment of dividends, -

Dividends declared, during the year, - -

Total per centage of dividends, for the year, -

Present surplus, -

\section{Miscellaneous.}

Increase during the year -

Of capital stock, as fixed by the charter, -

Of capital stock, as voted by the company, Of capital stock, paid in,

Increase of funded debt, during the year, -

Increase of floating debt, during the year, -

Decrease of funded debt, during the year, -

Decrease of floating debt, during the year, -

Increase of mortgage debt, during the year, -

Decrease of mortgage debt, during the year, -

Increase in cost of road, during the year, including amount charged for depreciation thereon,

Decrease in nominal cost of road, by amount charged for depreciation thereon,

Increase in cost of equipment, during the year, including amount charged for depreciation thereon,

Decrease in cost of equipment, by sale of any portion thereof, or by amount charged for depreciation

List of accidents on road during the year,

The road is now leased to the Malden and Melrose Railroad Co., for the remainder of the charter.
Amount received for rent, $\$ 1,12665$.

Amount due for rent to November 1 , not yetpaid,\$1,950 00 . There has been one dividend of 3 per cent. declared and paid.

\section{IUTHER FARWELL, PETER C. HALL, JAMES O. CURTIS, ELIHU C. BAKER, JOSEPH JAMES,}

Directors of the Medford and Charlestown Railroad Company. 


\section{COMMONWEALTH OF MASSACHUSETTS.}

Middlesex, ss. December 31, 1861.

Then personally appeared Luther Farwell, Peter C. Hall, James O. Curtis, Joseph James, and Elihu C. Baker, and severally made oath to the truth of the foregoing statement by them subscribed.

Before me,

BENJAMIN F. HAYES, Justice of the Peace. 



\title{
T H I R T E E N T H
}

\section{ANNUAL RETURN}

OF THE

\section{MEDWAY BRANCH RAILROAD}

\author{
COR P ORATI O N.
}

FOR THE YEAR ENDING NOV. 30, 1861.

$$
\text { B O S T O N : }
$$

WILIIAM FRASER, PRINTER, 1 1-2 THTER STIEHT. 


\title{
'TH IRTEENTH REPORT
}

\author{
OF THE
}

\section{MEDWAY BRANCH RAILROAD COMPANY.}

Capital Stock,.......................\$35,000 00

Capital Stock paid in as per last report,.......... 29,00000

'Total amount of Capital Stock, paid in,........... 29,00000

Number of share of Capital Stock,............. 29000

Floating debt, per last report,................. 3,78500

Maximum of floating debt,................... $\quad{ }_{4,012}^{22}$

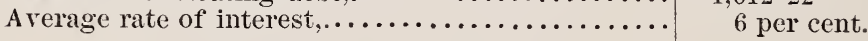

'Total cost of Road, no equipment, ........... 37,908 i5

\section{CHARACTERISTICS OF ROAD.}

Length of Road,$\ldots \ldots \ldots \ldots \ldots \ldots \ldots \ldots \ldots \ldots$.

Aggregate length of siding tracks,..............

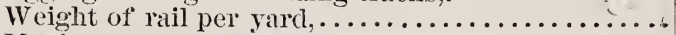

Maximum grade, with its length in main road,......

'Total rise and fall in road,.....................

Shortest radius or curvature with length of

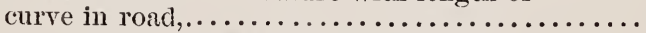

'Total degree of curvature in main road, ...........

Total length of straight line in main road,..........

Aggregate length of wooden truss bridges, ........

Aggregate length of all bridges,.................

Whole length of road unfenced,.................

Number of public ways crossed at grade, ..........

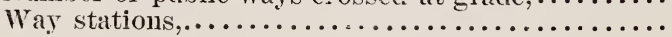

36 -10 miles.

3,262 feet.

40 to 42 pounds.

54 feet for 1100 feet.

70 feet.

70 feet for 500 feet.

$42^{\circ} 50^{\prime}$

13,800 feet.

107 feet.

250 feet.

40 feet.

2

1

The road has been mu by contract part of the year, no income to the road.

$\left.\begin{array}{l}\text { HOLMES AMMIDOWN, } \\ \text { JACOB W. PIERCE, } \\ \text { JACOB EDWARIS, JR. }\end{array}\right\} \begin{gathered}\text { Directors } \\ \text { of the } \\ \text { Medway Branch Railroad. }\end{gathered}$

Suffolk, ss. 1)ecember 31, 1861. Then personally appeared Messrs. H. Ammidown, Jacob W. Pierce and Jacob Edward, Jr., and made oath that the foregoing statement by them signed, is true, to their best knowledge and belief.

Before me,

THOMAS J. LEE, Justice of the Peace. 
Ninth

\section{ANNUAL REPOHT}

or Tiff

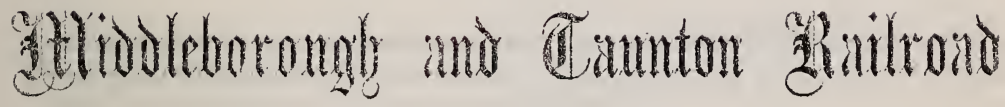

\section{COMPANY.}

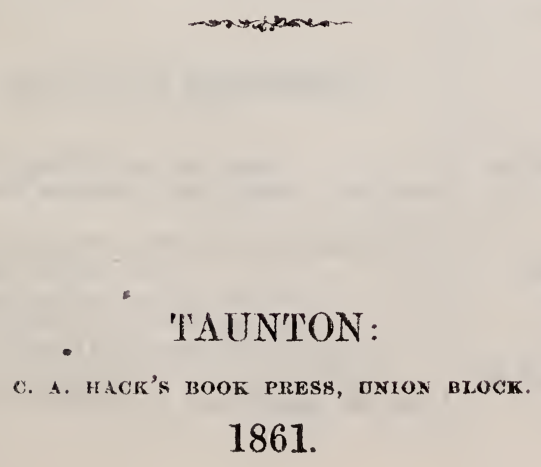




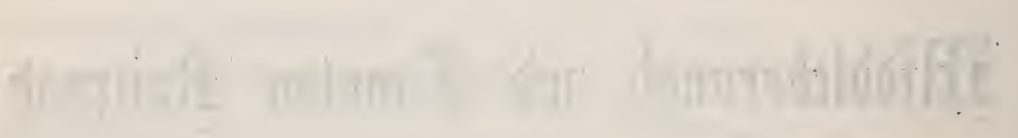

watemox:- 


\section{Jintf Alumual Repot}

Or Trte

\section{MIDDLEBOROUGH AND TAUNTON R. R.}

\section{COMPANY.}

Report of the Middieboro' and Taunton Rail Road, for the year ending November 30th, 1861.-General Statutes, chap. 63, sections 132 to 135.

\section{Capital Stock,}

Increase of Capital since iast Report

Capital paid in per last report,

Capital paid in since last report,

Total amount of Capital Stock paid in,

Nnmber of shares of Capital Stock issued,

Funded debt, per last report,

Funded debt paid, since last report,

Funded debt, increase of, since last report,

Floating debt, per last report,

Floating debt paid since last report,

Floating debt, increase of, since last report,

Total present amount of floating debt,

Total present amount of funded and floating debt, Maximum amount of debts during the year,

A verage rate of interest per annum, paid during the year,

\section{COS'T OF ROAD AND EQUTPMEN'T.}

For graduation and masonry, per last report,

For graduation and masonry, paid during the past year,

Total amount expended for graduation and masonry,

For wooden bridges, per last report,

For wooden bridges, paid during the past year,

'Total amount expended for wooden lridges,

'Total amount expended for iron bridges, (if any,)

For superstructure, including iron, per last report,

For superstructure, including iron, paid during the past year,
$\$ 150,00000$

$\$ 148,46700$

12540

1485

148,59240

7,80000

3,79998

11,59998

11,59998

6 per cent.

45,89914

38415

$45,899 \quad 14$

38415

56,02412 


\section{MIDDLEBOROUGH AND TAUNTON R. R.}

Total amount expendel for superstructure, including iron,

For stations, buildings, and fixtures, per last report,

For stations, buildings, and fixtmes, paid during the past year,

Total amount expended for stations, buildings and fixtures,

For land, land damages, and fences, per last report,

For land, land damages, and fences, paid during the past year,

Total amount expended for land, land damages, and fences,

For locomotives, per last report, . . . . . .

For locomotives, paid during the pest ycar, .

Total amount expended for locomotives,

For passenger and baggage cars per last report,

For passenger and baggage cars, paid during the past year,

Total amount expended for passenger and baggage cars,

For merchandise ears per last report,

For merchandise cars paid during the pist year.

Total amount expended for merchandise cars,

Tor engineering per last report,

for engineering paid during the past ycar,

Total amount expended for engineering,

For agencies and other expenses per last report,

For agencies and other expenses paid during the past year,

Total amount expended for agencies and other expenses,

Total cost of road and equipment,

Amount of assets of property held by the corporation in addition to the cost of the road,

\section{CHARACTERISTICS OF THE ROAD.}

Length of road,

Length of single main track, $\quad \cdot \quad \cdot \quad \cdot \quad \cdot \quad \cdot$

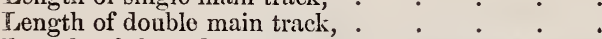

Length of branches owned by the Company, stating whether they have a single or double track,

Aggregate length of sidings and other tracks, excepting main tracks and branches,

Weight of rail per yard, in main road,

Weight of rail per yard, in branch roads,

Specify the different weights per yard,

Maximum grade, with its length, in main road,

Maximum grade, with its length, in branch roads,

Total rise and fall in main road, .

Total rise and fall in branch roads,

Shortest radius of curvature, with length of curve, in 'main road,

Shortest radius of curvature, with length of curve in branch roads,

3,99129

56,02412

18,00457

3,99129

$18,00+57$

9,28097

$2,5774.3$

9,28097

$2,577+3:$

9,13469

9,13463

3,94729

$3,9472 !$

4,69914

4,69914

$15: ;, 94279$

8,14887

8 536-1000 miles.

8 536-1000 miles.

2,955 fect.

$49 \mathrm{lbs}$.

$42 \mathrm{ft}$. in 4280

184 feet.

860 feet in 1174 feet. 


\section{MIDDLEBOROUGH AND TAUNTON R. R.}

Total degrees of curvature, in main road,

Total degrees of curvature in branch roads,

Total length of straight line in main road

Total length of straight line in branches,

Aggregate length of wooden truss bridges,

Aggregrate length of all other wooden bridges,

Aggregate length of iron bridges,

Whole length of road unfenced on both sides,

Number of public ways crossed at grade,

Number of railroads crossed at grade,

Remarks,

Way stations for express trains,

Way stations for accommodation tring, . .

Mlag stations,

Whole number of was stations,

Whole number of flag stations,

\section{DOINGS DURING TIIE YEAR.}

Miles run by passenger trains,

Miles run by freight tiains

Miles run by other trains,

Total miles run,

Number of passengers carried in the cars

Number of passengers carried one mile,

Number of tons of merchandise carried in the cars,

Number of tons of merchandise carricd one mile,

Number of passengers carried one mile to and from other roads,

Number of tons carried one mile to and from other roads,

Rate of speed adopted for express passenger trains, including stops,

Average rate of speed actually attained by express passenger trains, including stops and detentions, .

Rate of speed adopted for accommodation trains,

Rate of speed actnally attained by accommodation trains, including stops and detentions,

Average rate of speed actually attained by special trains, including stops and detentions,

Average rate of specd adopted for freight trains, includstops and detentions,

Sstimated weight in tons, of passenger cars, (not including passengers, ) lauled one mile

Tstimated weight in tons, of merchandise cars, (not including freight, ) hauled one mile,

\section{GXPENDITURES FOR WOIKING THE ROAD}

For repairs of road, maintenance of way, exclusive of wooden bridges and renewal of iron,

Wor repairs of wooden bridges,

For wages of switchmen, average per month,

For wages of gate-keepers, average per month,

For wages of signal men, average per month,

for wages of watchmen, average per month,

\section{0 degrecs.}

37,310 feet.

900 feet.

11

1.

3.

1.

3.

\section{0,655}

8,986

16,213

131,361 .

9,068 tous, $\quad 259$ lbs

60,843 " $1,46 \%$ :

129,049

56,606 tons, $1,547 \mathrm{lhs}$

25 miles per hour.

25 miles per hour.

14 miles per howr

$2,488 \quad 40$

28333 
Number of men employed, exclusive of thoso engaged in construction,

For removing ice and snow, (this item to include all labor, tools, repairs, and extra steam power used,

For repairs of fences, gates, houses for signal-men, gate keepers, switchmen, tool-houses,

Total for maintenance of way,

\section{MOTIVE POIVER AND CARS.}

For repairs of locomotives,

For new locomotives, to cover depreciation,

For repairs of passenger cars, . . . .

For new passenger cars to cover depreciation, .

For repairs of merchandise cars,

For new merchandise cars to cover depreciation, .

Total for maintenance of motive power and cars :

Number of engines,

Number of passenger cars, $\quad \cdot \quad \cdot \quad \cdot \quad \cdot$

Number of baggage cars, $\quad: \quad \cdot \quad \cdot \quad \cdot \quad \cdot \quad \cdot$

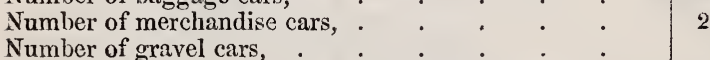

\section{MISCELLANEOUS.}

For fuel used by engines during the year, viz:-

Wood and Coal, cost of the same,

For Stations, Cars, Machine shop, \&c.,

For oil used by ears and engines,

For waste and other material for cleaning,

For salaries, wages, and ineidental expenses, elargeable to passenger department, .

For salaries, wages and incidental expenses, chargeable to freight department,

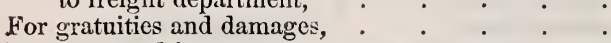

For taxes and insurance, $\quad . \quad . \quad . \quad . \quad$.

For ferries,

For repairs of station buildings, aqueducts, fixtures, and furniture, .

For renewals of iron, including laying down, .

For new iron laid down during the year, dedueting the value of old rail taken up,

For amount paid other companies, in tolls for passengers and freight carried on their roads, specifying each company, O C. \& F. R. R., Cape Cod, 'Taunton Branch, and N. B. \& T. R. R. Cos.,

For amount paid other companies, as rent for use of thicir roads, specifying each company,

For salaries of president, treasurer, superintendent, law expenses, office expenses of the above offices and all other expenses not included in any of the foregoing items,

Total Miscellaneous,

Total expenditures for working the road,

41058

30661

$1396 \%$ 


\section{MIDDLEBOROUGH AND TAUNTON R. R. ?}

\section{INCOME DURING THE YEAR.}

For Passengers :-

1. On main road, including branches owned by company,

2. To and from other roads, specifying what, Old Colony \& Fall River and New Bedford and 'Taunton.

For Freight:-

1. On main road and branches owned by company,

2. To and from other connecting roads,

U. S. Mails,

Rents and Interest,

Total income,

Loss,

\section{DIVIDENDS.}

Per cent. Total Surplus not divided, Surplus last year, Total surplus,
55899

8,34997

36283

9,60514

69492

19,57185

8366

\section{ESTIMATED DEPRECIATION BEYOND THE}

RENEWALS, viz :-

Roads and bridges, .

Buildings,

Engines and cars, .

\section{MORTGAGE DEBTS.}

Amount of debts, secured by mortgage of road and franchise, or any property of the Corporation, per last report,

Mortgage debt, paid since last report,

Increase of mortgage debt, since last report,

Present amount of mortgage debt,

Number of mortgages on road and franchise, or any property of the Corporation, 


\section{MIDDLEBOROUGH AND TAUNTON R. R.}

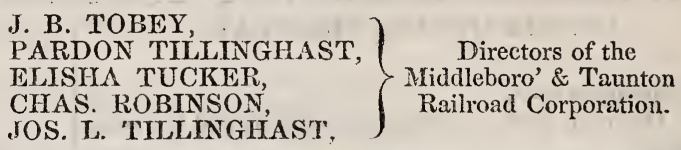

Surrolk ss. December 27th, 1861 . Then personally appeared J. S. Tillinghast and affirmed, and J. B. Tobey, P. Tillinghast, E. Tucker, and Charles Robinson, who severally rade oath to the truth of the foregoing statement by them subscriberl.

Before me,

E. PICKFRING, Justice of the Peace. 
T HE

\section{SIXTH RETURN}

OF THE

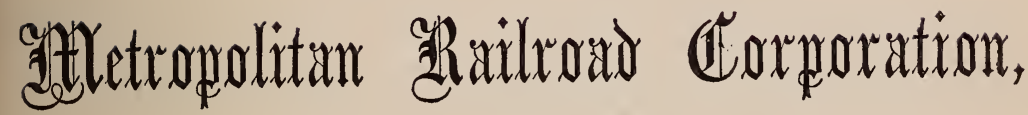

FOR THE

\section{YEAR ENDING NOVEMBER 30,}

\section{1.}

[UNDER ACTS OF 1857, CHAPTERS 40 AND 240.]

BOSTON:

HENRY W. DUTTON \& SON, PRINTERS,

90 and 92 Washington Street.

1862. 



\section{RETURN}

FOR THE YEAR ENDING NOVEMBER 30,

\section{1.}

\section{CONDITION OF THE COMPANY.}

Capital Stock, fixed by Charter, . . . . . $\$ 800,00000$

Capital Stock, as voted by the Company, . . . . 600,00000

Capital Stock paid in, in cash, . . . . . 490,000 00

Capital Stock paid in, in work and materials, by contractors, and others, . . . . . . . . . 110,00000

Funded Debt, . $\quad . \quad$. $\quad$. $\quad . \quad$. $\quad . \quad$. None.

Floating Debt (less mortgages), . . . . . . . 30,68106

Total Debt, . . . . . . . . . $\quad$. $75,773 \mathbf{7 4}$

A mount of above debt secured by mortgage of the road and franchise, or any property belonging to the Corporation, or standing in its name, . . . . . .

Number of mortgages on road and franchise, or any property of the Corporation, specifying the number and Four; on real amount of mortgages on road and franchise, and each estate and bond kind of property, . . . . . . . . Boston.

A mount of assets on hand, exclusive of the road and equipment, and exclusive of all property on hand, used or which is to be used in running the road and keeping it in repair, 


\section{COST OF THE ROAD.}

Amount expended for labor in excavating for the track, laying foundation and rails, . . . . . Amount expended for timber for foundation, . . . 28,241 04 Amount expended for iron and other metal for rails, chairs, spikes, or other articles used in building the road, . 138,452 04 Amount expended for paving stones, . . . . . . Amount expended for engineering, . . . . 7,83260 Amount expended for interest, salaries of officers during construction of road, and other expenses not included in any of the above items, which have been included, on the books of the Company, in the cost of the road, not including items of equipment or running expenses, as mentioned below,

96,70025

Total cost of road, . $\quad . \quad . \quad . \quad . \quad . \quad . \$ 400,50090$

Amount included in the present and in past years, among the running expenses for estimated or actual depreciation of the road, . . . . . . . . .

Net cost of road, . $\quad . \quad$. $\quad . \quad$. $\quad . \quad$. $\$ 374,00090$

\section{COST OF EQUIPMENT.}

Number of cars and cost, $-82, \quad$. . . . . . . $\$ 64,63790$

Number of horses and cost, -500, . . . . . . 66,116 44

Cost of omnibuses, sleighs and other vehicles, excepting - cars, owned by the Company, . . . . .

Cost of land and buildings thereon when purchased, (less mortgages, ) . . . . . . . .

$35,398 \quad 72$

53,21708

Cost of buildings used for offices, stables, \&c., erected by the Company, or standing on land not owned by the Company, . . . . . . . .

Cost of other articles of equipment, (specifying what):Office furniture, snow-ploughs, harnesses, stable fixtures, tools, \&c., . . . . . . . . 
Amount included in the present and in past years in the running expenses for estimated or actual depreciation of any of the above items, . . . . . 18,500 00

Net amount at which the equipment stands charged on the books of the Company, . $\quad$. $\quad . \quad$. $\quad$. $\$ 277,66623$

\section{CHARACTERISTICS OF THE ROAD.}

Length of single main track, . . . . 11,758 feet.

Length of double main track, . . . 9,575 "

Total length of road, . . . . . . 70,070 “

Length of branches owned by the Company, sta-

ting whether they have a single or double $\left\{\begin{array}{lll}36,592 & \text { " single. } \\ 12,145 \text { " double. }\end{array}\right.$

Aggregate length of switches, sidings, turnouts,

and other track, excepting main track and

branches, . . . . . . 6,121 "

Total length of rail, (equal to a single track, $18 \frac{28}{5} \frac{89}{4} \frac{8}{4}$ miles.

Weight of rail used, per yard, (specifying whether

of cast or rolled iron,) . . . . . 33 to $54 \mathrm{lbs}$. (rolled.)

Maximum grade per mile on road, with length of

grade, . . . . . . . 261 feet, for 500 feet.

Shortest radius of curvature, with length of curve, $32 \frac{40}{100}$ feet, for $46 \mathrm{ft}$.

Greatest length of single track on road between

two turnouts, . . . . . . 4,306 feet.

Total length of main track which is paved, . whole length.

\section{DOINGS DURING THE YEAR.}

Total number of miles run during the year, . . 1,252,019

Number of passengers carried in the cars, . . 5,810,119

Rate of speed adopted, including stops and deten: tions, . . . . . . . . average 6 miles.

Rate of speed actually attained, including stops and

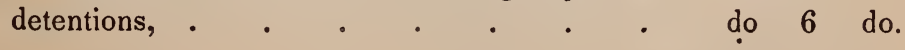


Number of persons employed, regularly, (specifying the occupations of each,) . . . . . . . 228 President, Superintendent, Treasurer, Superintendent's Clerk, 3 Receivers, 2 Foremen, 28 Mechanics, 57 Conductors, 57 Drivers, 35 Hostlers, 12 Watchmen, 7 Trackmen, 3 Starters, 6 Switchmen, 14 Helpers.

Total number of trips run during the year, . . . 384,385 Average number of passengers each trip, . . . $\quad 15$

\section{EXPENDITURES FOR WORKING THE ROAD.}

For repairs of road, including repairs of foundation, re. newals of iron, and renewals of pavement, . .

For general repairs, including repairs of cars, omnibuses and harnesses, and for shoeing horses, . . .

For repairs of real estate, including repairs of buildings used as stables, offices, or for any other purposes, by the Company,

For wages, including the wages of every person regularly employed, excepting the President, Directors, Superintendent and Treasurer, . . . . .

For interest, . . . . . . . . . . 4,549 52

For taxes and insurance, . . . . . . . $\quad$. 3,42586

For tolls paid other companies for the right to pass over their roads, . . . . . . . .

none.

For rent paid other companies for use of their roads, . For provender, - to include cost of hay, grain, straw, or other articles used for the food and bedding of horses,

For miscellaneous articles purchased during the yearsuch as harnesses, blankets, \&c., the use of which continues for one or more years-and not included in the cost of equipment, . . . . . . .

For loss on horses-that is to say, the difference between the present estimated value of the horses owned by the Company, subtracted from the estimated value of those on hand at the commencement of the year, added to the cost of those purchased during the year; or if this is the first report of the Company, then the difference between the estimated value of the horses on hand and their cost-giving the present average estimated value of each horse, 
For incidental expenses,-10 inciude printing,President's, 7 Directors', Treasurer's and Superintendent's salaries, and all expenses other than those belonging to the actual working of the road, (See Note A,)

For all other expenses,

\section{NOTE (A.)}

Salaries, (President, Superintendent and Treasurer,) . $\$ 9,30257$

Clearing snow from streets, . . . . . . 4,548 30

Legal expenses, . . . . . . . . 3,71500

Oil, fluid and gas, $\quad . \quad$. $\quad . \quad$. $\quad . \quad$. $\quad . \quad$. 3,59835

Rents, (offices, stables, \&c.,) . . . . . . . . $\quad$. 3,53566

Damages, . . . . . . . . . . 2,553 36

Books, stationery and printing, . . . . . . 1,12890

Watering streets, . . . . . . . . . 1,11250

Water tax, . . . . . . . . 68000

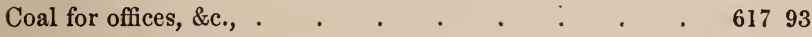

Horse doctor and medicines, . . . . . . 25448

Tickets, . . . . . . . . . . 21750

Gas regulators and burners, . . . . . . . 7266

Advertising, . . . . . . . . . . 6525

Music, (May morning,) . . . , . . . 2500

Pasturing horses, . . . . . . . . . 11034

Sundry expenses, . $\quad . \quad$. $\quad . \quad$. $\quad . \quad$. $\quad . \quad 1,69819$

$\$ 33,23599$

For amount charged on the Company's books during the year, for estimated or actual depreciation of the following property :-

Cars, .

Horses,

Omnibuses, .

Real Estate,

Road,

Other property,

Total,

Total expenses, 


\section{EARNINGS.}

Received from passengers in cars and omnibuses, and for tickets sold

From other roads, as toll or rent for use of road, From United States mails, . . . . . . . 25195

For sales of manure, . $\quad$. $\quad$. $\quad$. $\quad$. $\quad$. $\quad$. 3,18658

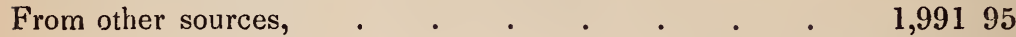

Total earnings, . . . . . . . . $\$ 286,27015$

Net earnings, after deducting expenses, . . . . 48,422 11

Surplus earnings of previous year on hand, . . . 4 41,221 33 Net earnings, as above, . $\quad . \quad$. . . . . 48,422 11

Total surplus for payment of dividends, . . . . 89,64344 Dividends declared, during the year, . . . . 48,00000 Total percentage of dividends, for the year, . . $\quad$. 8 per cent. Present surplus, . . . . . . . . . . 41,64344

\section{MISCELLANEOUS.}

Increase during the year-

Of capital stock, as fixed by the charter, . . . none.

Of capital stock, as voted by the Company, . . none.

Of capital stock, paid in, . . . . . none.

Increase of funded debt, during the year, . . . none.

Increase of floating debt, during the year, . . . 14,748 33

Decrease of funded debt, during the year, . . . none.

Decrease of floating debt, during the year, . . . none.

Increase of mortgage debt, during the year, . . . none.

Decrease of mortgage debt, during the year, . . . $\quad 5,00716$

Increase in cost of road, during the year, including amount charged for depreciation thereon, . . . .

Decrease in nominal cost of road, by amount charged for depreciation thereon,

7,01242

26,50000

Increase in cost of equipment, during the year, including amount charged for depreciation thereon,

5,32968

Decrease in cost of equipment, by sale of any portion thereof, or by amount charged for depreciation, 
List of accidents on road during the year:-

January 2. Four horses, attached to a sleigh, ran away and fatally injured a boy.

February 9. Four horses, attached to a sleigh, ran away and severely injured the conductor and one passenger.

June 14. Two women, riding in a chaise by the side of the track, drove their horse immediately in front of a car while in motion, and were thrown from the chaise-both were injured-one fatally.

July 12. A man attempting to jump from one car to another while in motion, fell under the wheels and was run over.-Severely injured.

September 18. A boy ran in front of a car while in motion, and had a bone of his ankle broken.

November 30. Five persons have been slightly injured at different times, by jumping from the cars while in motion, without giving notice to the conductor.

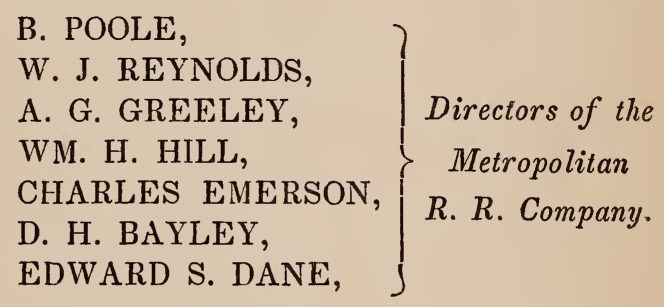

Suffolk, ss. December 9, 1861.

Then personally appeared B. Poole, W. J. Reynolds, A. G. Greeley, Wm. H. Hill, Charles Emerson, D. H. Bayley, Edward S. Dane, and severally made oath to the truth of the foregoing statement by them subscribed. Before me,

O. H. SPURR, Justice of the Peace. 





$$
\text { S I } \mathrm{X} \quad \mathrm{T} H
$$

\title{
ANNUAL REPORT
}

\author{
O F T H E
}

\section{MIDDLESEX RAILROAD COMPANY}

T O TH E

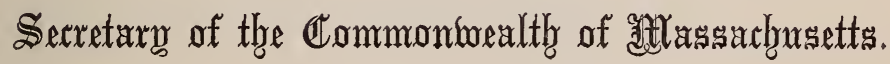

FOR THE YEAR ENDING NOVEMBER 30th, 1861.

\section{CHARLESTOWN :}

PRINTED BY W. W. WHEILDON. 



\section{MIDDLESE RAILROAD COMPANY.}

For the Year ending November 30th, 1861.

Report of the Directors of the Middlesex Railroad Company, under General Statutes, Chapter 6\%. Sects. 14\%, 144.

\section{Condition of the Company.}

Capital stock, fixed by charter, - -

Capital stock, as voted by the company,

Capital stock paid in, in cash, _ _ -

Capital stock paid in, in work and materials, by contractors and others,

Funded debt,

Floating debt, - $\quad-\quad+\quad-\quad-\quad-\quad-$

Total debt,

Amount of above debt secured by mortgage of the road and franchise, or any property belonging to the corporation, or standing in its name,

Number of mortgages on road and franchise, or any property of the corporation, specifying the number and amount of mortgages on road and franchise, and each kind of property,

Amount of assets on hand, exclusive of the road and equipment, and exclusive of all property on hand, used, or which is to be used, in running the road and keeping it in repair,

COST OF THE ROAD.

Amount expended for labor in excavating for the track, laying foundations and rails,

Amount expended in timber for foundation, -

Amount expended for iron and other metal for rails, chairs, spikes, or other articles, used in building the road,

Amount expended for paving, - $\quad$ -

Amount expended for paving stones, - -

Amount expended for engineering, - -

Amount expended for interest, salaries of officers during construction of road, and other expenses not included in any of the above items, which have been included, on the books of the company, in the cost of the road, not including items of equipment or running expenses, as mentioned below, - _ -

Total cost of road, - $\quad$ - $\quad$ -

Amount included in the present and in past years, among the running expenses for estimated or actual depreciation of the road, -
$\$ 400,00000$

$\$ 350,00000$

$\$ 348,000 \quad 00$

Nothing.

66

60,00

Unclaimed div. 60,00

Nothing.

None.

$\$ 170$

This Road was built by contract. Items unknown.

348,00000

Unknown; borne by lessee. 


\section{Cost of Equipment.}

Number of cars and cost, -

Number of horses and cost,

Cost of omnibuses, sleighs and other vehicles, excepting cars, owned by the company,

Cost of land and buildings thereon when purchased,

Cost of buildings used for offices, stables, \&c., erected by the company, or standing on land not owned by the company,

Cost of other articles of equipment, (specifying what,)

Total cost of equipment,

Amount included in the present and in past years in the running expenses for estimated or actual depreciation of any of the above items,

Net amount at which the equipment stands charged on the books of the company,

\section{Characteristics of the Road.}

Length of single main track,

Length of double main track,

Total length of road, -

Length of branches owned by the company, stating whether they have a single or double track,

Aggregate length of switches, sidings, turnouts and other track, excepting main track and branches,

Total length of rail

Weight of rail used, per yard, (specifying whether of cast or rolled iron,)

Maximum grade, per mile on road, with length of grade,

Shortest radius of curvature, with length of curve,

Greatest length of single track on road between two turnouts, -

Total length of main track which is paved, -

\section{Doings DURING the Year.}

Total number of miles run during the year, -

Number of passengers carried in the cars,

Rate of speed adopted, including stops and detentions,

Rate of speed actually attained, including stops and detentions,

Number of persons employed, regularly, (specifying the occupations of each,)

Total number of trips run during the year, -

Average number of passengers each trip,
This Road is under lease to the Malden and Melrose Railroad Co., who furnish the entire equipment.

$11,442 \frac{1}{2} \mathrm{ft}$.

10,119 66

$21,561 \frac{1}{2}$ ،6

Somerville Branch, $2,276 \mathrm{ft}$. single track.

Bunker Hill Branch, $5,633 \mathrm{ft}$. single track.

$944 \mathrm{ft}$.

12 miles $1859 \mathrm{ft}$.

\} 80 lbs. Cast iron.

56 lbs. Wrought iron.

$251 \mathrm{ft}$. Length $400 \mathrm{ft}$. ) Radius $36 \mathrm{ft}$. Length of $\operatorname{arc} 58 \mathrm{ft}$.

$2,782 \mathrm{ft}$. $21,561 \frac{1}{2}$ ،

Unknown.

Treasurer and Clerk.

Unknown. 
EXPenditures for Working the ROAD.

For repairs of road, including repairs of foundation, renewals of iron, and renewals of pavement,

For general repairs, including repairs of cars, omnibuses and harnesses, and for shoeing horses,

For repairs of real estate, including repairs of buildings used as stables, offices, or for any other purposes, by the company,

For wages, including the wages of every person regularly employed, excepting the president, directors, superintendent and treasurer, -

For interest,

For taxes and insurance, - $\quad$ -

For tolls paid other companies for the right to pass over their roads,

For rent paid other companies for use of their roads,

For provender, - to include cost of hay, grain, straw, or other articles used for the food or bedding of horses,

For miscellaneous articles purchased during the year - such as harnesses, blankets, \&c., the use of which continues for one or more years - and not included in the cost of equipment,

For loss on horses - that is to say, the difference between the present estimated value of the horses owned by the company subtracted from the estimated value of those on hand at the commencement of the year, added to the cost of those purchased during the year; or if this is the first report of the company, then the difference between the estimated value of the horses on hand and their cost - giving the present av. estimated value of each horse,

For incidental expenses, - to include printing, president's, directors', treasurer's and superintendent's salaries, and all expenses other than those belonging to the actual working of the road,

For all other expenses,

For amount charged on the company's books during the year, for estimated or actual depreciation of the following property:-

\section{Cars,}

Horses,

Omnibuses,

Real Estate,

Road,

Other property, -

Total,

Total expenses, -
Unknown.

$575 \quad 50$

Nothing.

Borne by lessee. 


\section{Earnings.}

Received from passengers in cars and omnibuses, and for tickets sold,

From other roads, as toll or rent for use of road,

From United States mails, - - - -

For sales of manure, - $\quad$ - $\quad$ -

From other sources, - $\quad$ - $\quad$ -

Total earnings, - $\quad$ - $\quad$ - $\quad$ - $\quad$ -

Net earnings, after deducting expenses, -

Surplus earnings of previous year, on hand, -

Net earnings, as above,

Total surplus for payment of dividends, -

Dividends declared, during the year, - -

Total per centage of dividends, for the year, -

Present surplus;

\section{Miscellaneous.}

Increase during the year-

Of capital stock, as fixed by the charter, -

Of capital stock, as voted by the company,

Of capital stock, paid in,

Increase of funded debt, during the year, -

Increase of floating debt, during the year, -

Decrease of funded debt, during the year, -

Decrease of floating debt, during the year, -

Increase of mortgage debt, during the year, -

Decrease of mortgage debt, during the year, -

Increase in cost of road, during the year, including amount charged for depreciation thereon,

Decrease in nominal cost of road, by amount charged for depreciation thereon,

Increase in cost of equipment, during the year, including amount charged for depreciation thereon,

Decrease in cost of equipment, by sale of any portion thereof, or by amount charged for depreciation, -

List of accidents on road during the year, -
Received by lessee. $28,525 \quad 50$

Received by lessee.

$28,525 \quad 50$

27,840

None.

27,840

27,840

27,840

8 per cent.

$11,63333 \%$

None.

None.

None.

None.

\$12

None.

None.

None.

None.

Nothing.

None.

Unknown. Owned by lessee.

Reported by lessee.

*This amount includes Rent accrued not yet due.

Note. - This Road is leased to the Malden and Melrose Railroad Company, who pay a semi-annual rental equal to 4 per cent. (or 8 per cent. per annum) on each share of the capital stock of the Middlesex Railroad Company - also other necessary expenses.

JOHN H. BLAKE, FRANKLIN DARRACOTT, E. F. HODGES, GEO. W. PALMER, 


\section{COMMONWEALTH OF MASSACHUSETTS.}

SufFoLK, ss.

Boston, December 26, 1861.

Then personally appeared the said Blake, Darracott, Hodges, and Palmer, and severally made oath that the foregoing statement, by them subscribed, is true, according to their best knowledge and belief.

Before me,

WILLIAM STANDISH, Justice of the Peace. 



\section{FOU R T H}

\section{ANNUAL RETURN}

OF THE

\section{MIDLAND RAILROAD}

\section{CORPORA TION.}

FOR THE YEAR ENDING NOVEMBER 30, 1861.

BOS TON :

WRIGHT \& POTTER, PRINTERS, 4 SPRING LANE.

1861 . 


\section{FOURTH ANNUAL RETURN}

OF THE

\section{MIDLAND RAILROAD CORPORATION.}

Return of the Midland Railroad Corporation, for the year ending November 30, 1861, required by Acts of 1849, Chap. 191; 1851, Chap. 102; 1854, Chap. 423; 1856, Chap. 165 ; 1857, Chaps. 40, 168, and 240; and 1858, Chap. 46.

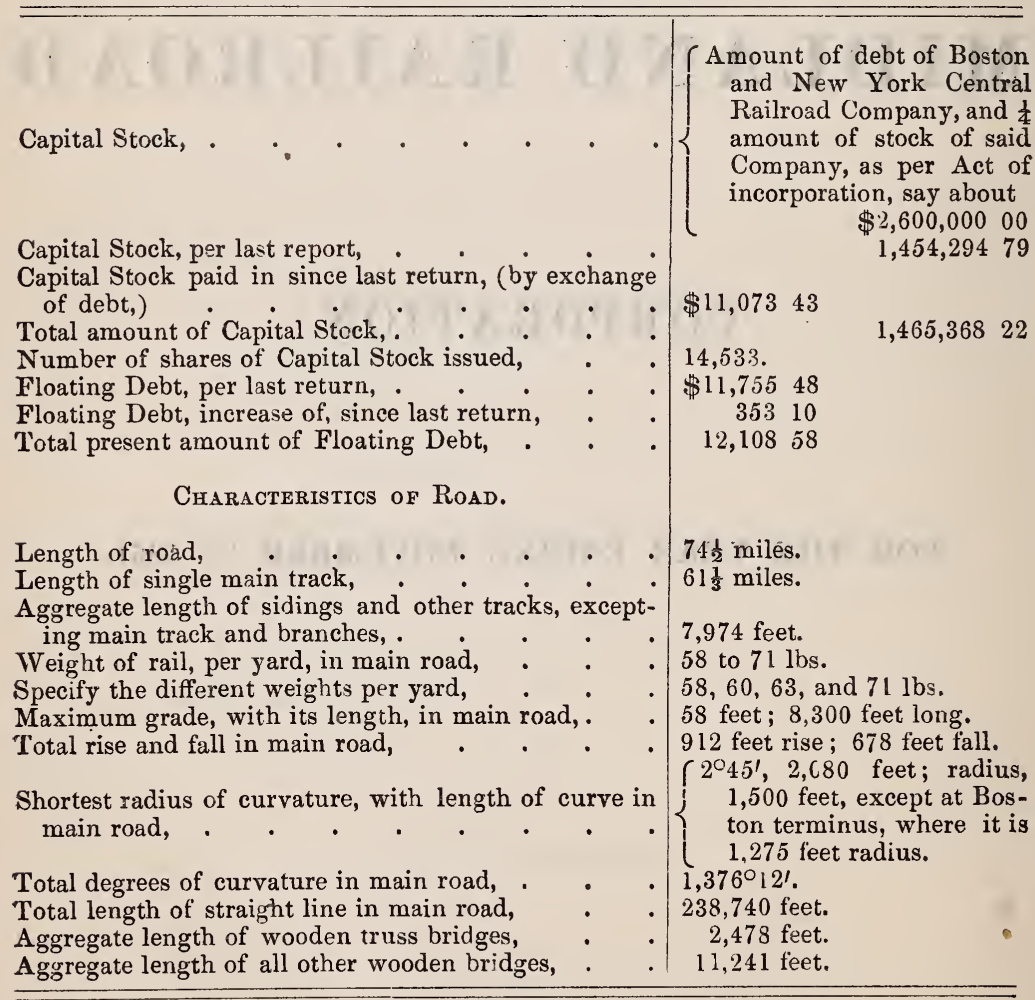

In submitting their Fourth Annual Return, the Directors would say, that the Midland Railroad Corporation was incorporated for the purpose of succeeding to the property of the Boston and New York Central Railroad Company, by arranging with the various classes of creditors of said Boston and New York Central Railroad Company, to exchange their debts for stock in the new Company. 
Claims to the amount of $\$ 1,465,365.22$ have been exchanged, and stock to the amount of 14,533 shares have been issued therefor; but the claims for land damage, and the bonds secured by the mortgage of the Norfolk County Railroad have not been purchased, therefore the Company have not been able to run their road.

That portion between Dedham and Blackstone has been operated by the Trustees, under the mortgage of the Norfolk County Railroad.

For the above reasons, the report of this Company is more brief than the reports of railroads in active operation.

A. G. FARWELL.

J. W. CLARK.

WARREN HUNT.

ALEXANDER DE WITT.

Sufrouk, ss., December 31, A. D. 1861. Personally appeared A. G. Farwell, J. W. Clark, Warren Hunt, Alexander De Witt, and severally made oath that the above return is true, according to their best knowledge and belief.

Before me,

SAMUEL W. BATES, Justice of the Peace. 



\section{FIRST ANNUAL REPORT}

OF THE

\section{MIDLANI) LAND DAMAGE COMPANY.}

'The Midland Land Damage Company, Chartered by the Legislature of Massachusetts, and approved by the Governor April 9, 1861, was organized June 7 th last, in accordance with the provisions of their Charter, and the parties named in the first section of their Act of Incorporation, unanimously roted to accept said Act, and filed the ccrtificate thercof with the Secretary of State, June 8th, 1861.

In consequence of the failure of The Midland Railroad Company to accept of the provisions of the Act, this Company find themselves under the necessity of waiting further action till the Midland Charter expires, as provided in said Act. .

$$
\left.\begin{array}{l}
\text { JOSEPH W. WARD, } \\
\text { S'JEPHEN BAKER, } \\
\text { EDWARD CRANE, } \\
\text { J. S. 'T. CUSHING, } \\
\text { O. S. SANFORD. }
\end{array}\right\}
$$

Sufrolk, ss. Dec. 13, 1861.

Then personally appearsd, the above named Joseph W. Ward, Stephen Baker, Edward Crane, J. S. T. Cushing, and O. S. Sanford, and acknowledged the above to be true to the best of their belief and knowledge.

DANIEL SHARP, Justice of the Peace. 



\section{commontoalth of actlassachusetts.}

ANNUAL REPORT OF 'THE MILFORD \& WOONSOCKE'T RAILROAD CORPORATION, ENDING NOVEMBER 30. 1861.

The Milford \& Woonsocket Railroad Corporation would respectfinlly report to the Legislature,

That the road is not yet built, but that all necessary surveys hare been made, and the means secured for the building of the road, whenever that portion of the New-York \& Boston Railroad between Bellingham and Woonsocket, Rhode Island, if eompleted.

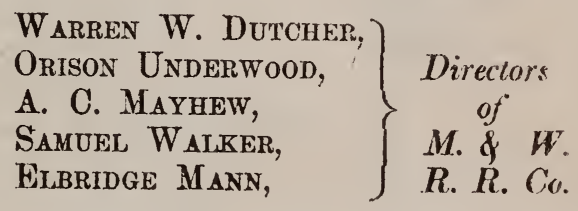

WOHCESTER, SS.

December 21 st, 1861.

'Then personally appeared 0 . Underwood, Eilbridge Maun. Samuel Walker, Warren W. Dutcher and A. C. Mayhew, abovemaned, and made oath that the foregoing return is true, according to their best knowledge and belief.

Before me,

T. G. Kavr,

Justice of the Pease. 
atham

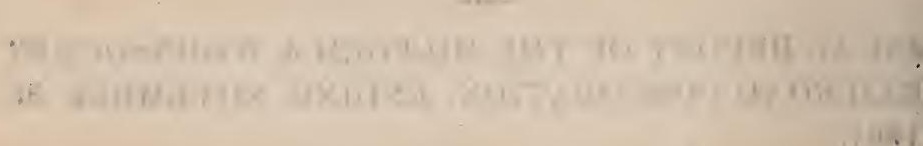

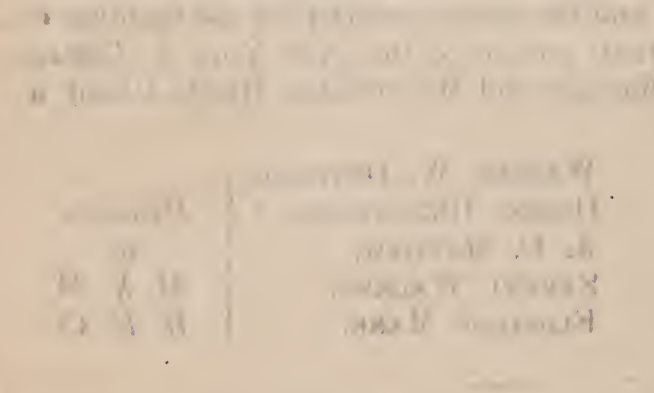

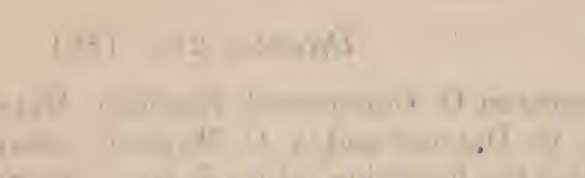

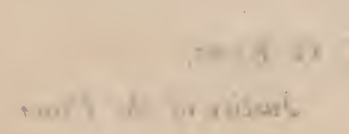




\section{REPORT OF THE DIRECTORS}

OF THE

\section{NASHUA AND LOWELL RAILROAD CORPORATION,}

For the Year ending Nov. 30, 1861.

Capital Stock,

Number of shares of capital stock issued,

Increase of Capital, since last report, .

Capital paid in, per last report, .

Capital paid in, since last report,

Total a mount of capital stock paid in, :

Fuuded debt, per last report,

Funded debt, paid since last report,

Funded debt, increase of, since last report,

Total present amount of funded debt, .

Floating debt, per last report,

Floating debt, paid since last report

Floating debt, increase of, since last report,

Total present amount of floating debt,

Total present amount of funded and floating debt,

Average rate of interest per annum, paid dur-

ing the year,

Maximum amount of debts during the year,

\section{Cost of Road and Equipment.}

For graduation and masonry, per last report, .116,827 63

For graduation and masonry, paid during the

Total amount expended for graduation and ma-

sonry,

For wooden bridges, per last report,

For wooden bridges, paid during the past year, Nons0 35

Total amount expended for wooden bridges,

Total amount expended for iron bridges,

For superstructure, including iron, per last report,

For superstructure, including iron, paid during the past year,

Total amount expended for superstructure, including iron
6,000

$\$ 600,00000$

. None.

600.00000

- None.

600,00000

.

This Corporation has no debt. 
For stations, buildings and fixtures, per last report,

For stations, buildings and fixtures, paid during the past year,

ended for stations, . None.

and fixturt expended for stations, buildings

For land, land-damages and fences, per last report,

For land, land-damages and fences, paid during

the past year, . . . None.

Total amount expended for land, land damages and fences,

For locomotives, per last report,

For locomotives, paid during the past year, .None.

Total amount expended for locomotives,

For passenger and baggage ears, per last report, 13,792 71

93,19695

For passenger and baggage cars, paid during

the past year, ${ }^{\text {Total a mount expended for passenger and bag- }}$ gage cars, None.

For merchandise cars, per last report, : $\quad 35,65109$

For merchandise cars, paid during the past year, None.

Total amount expended for merchandise cars,

For engineering, per last report,

21,51061

For engineering, paid during the past year, .None.

Total a mount expended for engineering,

For agencies and other expenses, per last re-

For agencies and other expenses, paid during the past year, . . . .

Total amount expended for agencies and other expenses,

Total cost of road and equipment, .

Amount of assets or property held by the corporation in addition to the cost of the road.Real Estate at Lorvell and Chelmsford not used for the immediate purposes of the Road, $\$ 11,93743$; working materials for use of Road, $\$ 37,79511$, and balance of surplus funds in notes and cash.

\section{Characteristics of Road。}

Length of Road,

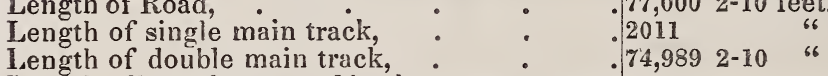

Length of branches owned by the company, stat-

ing whether they have a single or double track, None.

Aggregate length of sidings, and other tracks, excepting main track and branches, . 3 miles.

Weight of rail, per yard, in main road, . $56 \mathrm{lbs}$.

Weight of rail, per yard, in branch roads, (specify the different weights, per yard,) .

Maximum grade, with its length, in main road, 12 7-10 ft. pr. mile. 4135

Maximum grade, with its length, in branch

roads, None.

Total rise and fall in branch roads, : None.

Shortest radius of curvature, with length of

Shortest radius of curvature, with length of curve in branch roads, . 
Total degrees of curvature in main road, .1770.

Total degrees of curvature in branch roads, None.

"Total length of straight line in main road, .7 22-100 miles.

Total length of straight line in branches, . None.

Aggregate length of wooden truss bridges, .530 feet.

A ggregate length of all other wooden bridges, $664 \quad 66$

Aggregate length of iron bridges, None.

Whole length of road unfenced on both sides, None.

Number of public ways crossed at grade, . 10.

Number of railroads crossed at grade, . $\quad 1$.

Remarks, • • • • . *

Way stations for express trains, $\quad: \quad$ None.

Way stations for accommodation trains, 2.

Flag stations, . 3.

Whole number of way stations, $\quad{ }^{\circ}$.

Whole number of flag stations, . $\quad: \quad 3$.

DoINGS DURING THE YEAR.
[Including our proporlion on Wilton, Stony Brook, Salem \& Lowell and Lowell \& Lawrence Railroads.]

Miles run by passenger trains, . . . 82,532

Miles run by freight trains, $\quad . \quad \quad \quad . \quad 78,171$

Miles run by other trains, $\quad: \quad$ None.

Total miles run, . $\quad . \quad$. 160,703

Number of passengers carried in the cars, $\quad \mathbf{2 7 3 , 3 0 5}$

Number of passengers carried one mile, $3,446,140$

Number of tons merchandise carried in the cars, 166,399

Number of tons merchandise carried one mile, $2,818,035$

Number of passengers carried one mile, to and from other roads, $\quad 1,185,664$

Number of tons carried one mile, to and from other roads, $1,866,738$

Rate of speed adopted for express passenger?

$\begin{gathered}\text { trains, including stops, } \\ \text { Average rate of speed actually attained by ex- }\end{gathered} \mid$ None run. press passenger trains, including stops and detentions,

Rate of speed adopted for accommodation trains, tion trains, including stops and detentions, .25 miles per hour.

Average rate of speed actually attained by special trains, including stops and detentions, 25 miles per hour.

Average rate of speed adopted for freight trains, including stops, .

Estimated weight in tons of passenger cars, (not includiug passengers, ) hauled one mile,

Estimated weight in tons of merchandise cars, (not including freight,) hauled one mile, )

\section{Expenditures for Working the Road.}

For repairs of road, maintenance of way, exclusive of wooden bridges, and renewals of

For repairs of wooden bridges, :

For wages of switchmen, average pr. mo. \$

For wages of gate keepers, average "6 "\$

$\left.\begin{array}{llll}\text { For wages of gate keepers, average " } & \text { " } & \$ \\ \text { For wages of signal-men, average } & \text { " } & \$ & \$\end{array}\right\}$

Number of men employed, exclusive of those engaged in construction,

10 miles per hour.

Cars not weighed. 
For removing ice and snow, (this item to include all labor, tools, repairs, and extra steam power used.)

For repairs of fenees, gates, houses for signalmen, gate-keepers, switchmen, tool-houses,

Total for maintenance of way,

1,45349

Motive Power and Cars.

For repairs of locomotives,

For new locomotives to cover depreciation,

For repairs of passenger cars,

For new passenger cars, to cover . 4,775 83

For repairs of merchandise cars, For repairs of merchandise cars,
tion,

For repairs of gravel and other cars,

Total for maintenance of motive power and cars

Number of engines,

Number of pas senger cars, $\quad: \quad \vdots \quad: 12$.

Number of baggage cars, : : 7 . 7 .

Number of merchandise cars, : $\quad$ : 337.

Number of gravel cars, . $\quad$. $\quad$ Included in above.

\section{Miscellaneods.}

For fuel used by the engines during the year,viz: $\$ 11,52062$

Wood, number of cords, 2,209. Cost of the same,

Coal, number of tons, (reckoning 2,240 lbs. to

the ton,) 1,000. Cost of the same, .

For oil used by cars and engines, . $\quad 3,08105$

For waste and other material for cleaning, Included in above.

For salaries, wages and incidental expenses, chargeable to passenger department,

For salaries, wages and incidental expenses, chargeable to freight department

For gratuities and damages,

For taxes and insurance,

For ferries,

For repair's of station buildings, aqueducts, fixtures, furniture,

For renewals of iron, including laying down,

For new iron laid down, deducting the value of old iron taken up,

For amount paid other companies, in tolls for ? passengers and freight carried on their roads, specifying each company, . .

For amount paid other companies, as rent for use of their roads, specifying each company. Stony Brook R. R.

Lowell \& Lawrence R. R. per contract,

Sal, 651 80 5,48700 Salem \& Lowell R.R. per contract, 5,425 00
Wilton R. R.

For salaries of president, treasurer, superintendent, law expenses, office expenses of the above offices, and all other expenses, not included in any of the foregoing items,

Total miscellaneous

11,24912

24,55195

1,58119

$3,766 \quad 12$

1,96802

$7,315 \quad 47$

19,03803

29,06265

hing.

Nothing.

cluded in above.

Nothing.

,

31,66380

Total expenditures for working the road,

Total amount of interest paid during the year, Nothing. 


\section{Income During the Year.}

For Passengers :-

1. On main road, including branohes owned?

2. To and from otherroads,specifying what, $\} \$ \$ 80,07610$

For Freight:-

1. On main road and branches owned by ?

$\left.\begin{array}{l}\text { Company, } \\ \text { 2. To and from other connecting roads, }\end{array}.\right\}\left\{\begin{array}{rl}111,837 & 30 \\ 2,890 & 16\end{array}\right.$

U. S. Mails, • • • • • . 2,89016

Express, Interest, and miscellaneous receipts, $\quad \begin{aligned} & 9,571 \\ & 22\end{aligned}$

Total Income, . . . . .

Net earnings, after deducting expenses,

\section{Dividends.}

8 per cent. Total, Surplus not divided, as per memo.* $\$ 3,82953$, . 103,94263

Total surplus,

Estimated Depreciation beyond the ReNEWALS, VIZ :

Road and bridges,

Building,

Engiues and cars,

\section{Mortgage Debts.}

Amount of debts, secured by mortgage of road and franchise, or any property of the Corporation, per last report,

Mortgage debt, paid since last report,

Increase of mortgage debt since last report,

Present amount of mortgage debts, any property of the corporation,

* Contingent Fund has been reduced during the year, by the following payments :

For land bought of Wm. E. Livingston, at Lowell,

6 Registering Deeds,

• • • • • . . . $\quad \begin{array}{r}300 \\ \hline\end{array}$

"s Land bought of Robert Brinley, at Tyngsboro', • . • . • . $\quad . \quad 1,50000$

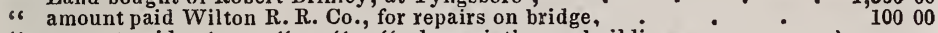

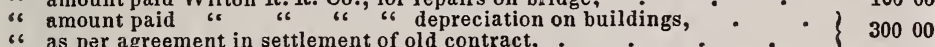

is as per agreement in settlement of old contract, * amount paid Wilton R. R. Co., their proportion of suspense acc't, $\quad$ • $\quad 92653$

is amount paid Wilton R. R. Co., their proportion of suspense acc't, $\frac{92653}{\$ 3,82953}$

\section{Accidents.}

Dec. 5, 1860.-Hiram Bellows, brakeman on passenger train, had his leg broken in consequence of the misplacement of a switch, in the Repair Shop Yard, at Nashua.

$\mathcal{N}$ ov. 30, 1861.-Nathaniel B. Jones, freight conduetor, was killed by coming in contact with a bridge, in Tyngsborough. 


\section{WILTON RAILROAD CONTRACT.}

This Indenture, made this second day of May, A. D., 1860, between the Wilton Railroad Company, established by the laws of the State of New.Hampshire, of the first part, and the Nashua and Lowell Railroad Corporation, established by the laws of the State of New-Hampshire and by the laws of the Commonwealth of Massachusetts, of the second part ;

WITNESSETH :-

That whereas, by the laws of the said States, respectively, Railroad Corporations are authorized and empowered to contract with each other for the use of their roads and for the transportation of freight or passengers, and the conducting of all business connected therewith on their road, upon such conditions as may be mutually agreed upon by the parties and whereas the mutual interest of the parties and of the public is helieved to have been promoted by the use and management of the railroad of the party of the first part, during the past seven years, by the party of the second part under the consent and approval of the proper Jegal authorities, and in the opinion of the parties hereto, the extension of a similar arrangement from and after the termination of the present lease on the first day of April, 1860, would operate beneficially for all concerned,-

Now, therefore, the said Wilton Raslroad Company, party of the first part, in consideration of the covenauts herein contained, on the part of the Nashua and Lowell Railroad Corporation, party of the second part, to be kept and performed, and for the purposes and objects aforesaid, doth deliver up to said second party, their successors and assigns, and put them in full possession of the whole of their said Wilton Railroad, extending from the Nashua \& Lowell Railroad in the City of Nishua to the village of East Wilton, including all turnouts, switches, turntables, station houses, buildings and other property, whether included in the ir location or not; all of which is duly inventoried and appraised by appraisers mutually agreed upon in the schedule thereof, hereunto annexed. Meaning hereby to deliver up to said Nashua \& Lowell Railroad Corporation, and put them in possession of, as aforesaid, all the property of said Wilton Railroad Comiany, of every description whatsoever, both real and personal, whether the same be particularly described herein or not; with the exception only of the bills, books of accounts, notes receivable, and all other debts and claims now due to the said Wilton Railroad Company on its own separate account. To have and to bold the same, all and singular, to the said Nashua \& Lowell Railroad Corporation for the term of eighteen years, commencing on the first day of April, A. D., one thousand eight hundred and sixty. Provided however, that if the Legislature of New Hampshire shall refuse to sanction the same, and if the Governor and Council and the Railroad Commissioners of said State shall refuse to endorse their approval upon the same at the times and in the manner now provided by law, then this contract shall terminate from and after such final refusal; otherwise to remain in full force for the time above specified.

And the said second party may use, run, operate, monage, control and administer the said railroad and property of the party of the first part, as fully as said party of the first part might do, and in such manner as said party of the second part shall determine upon; may transport passengers, freight and mails over and upon the same, and do and transact any other business authorized by the charter of said Wilton Railroad Company ; and for the purposes and objects above set forth, and in consideration of the stipulations and things herein provided to be done and performed by said second party, said party of the first part do hereby deliver up and entrust their said railroad and other property to said party of the second part, for the term of eighteen years, or as aforesaid, and do delegate to them all their powers to manage and regulate the same, and to collect tolls and income thereon, for the sole benefit of said second party. 
And whereas the buildings and depor arrangements of the party of the first part at East Wilton, are now of a temporary character, and unsuited to the wants of the business, said party of the first part hereby agrees to reconstruct and re-arrange the same during the summer of 1860 , at their own separate expense, upon such plans, and in such permanent style of structure as shall be satisfactory to the party of the second part, at an expense not exceeding six thousand dollars over and above the value of the present structures.

The said fist party also agree on their part, to warrant and defend the said second party in quiet possession of the said road and property, during the tertn aforesaid, against the claims and demands, or attempto ed seizure or possession of said road or property, by any and all persons, creditors, or claimants, upon suits or demands against said first party, other than claims growing out of the operation of the said Wilton Railroad by the said second party, under this contract; and, at its own separate cost and expense, to keep up its corporate organization and official Board of Directors during the continuance of this agreement, and to pass and perform all such official acts as may from time to time become necessary for the legal and proper management of the road and property.

And said party of the second part, for themselves, their successors and assigns, in consideration of the premises, do hereby agree, for and during the term of eighteen years, or as aforesaid, to manage said property in accordance with the provisions of the charter of the Wilton Railroad, to do and perform all the transportation of persons and freight, upon and over the railroad of the party of the first part, and to run and operate said railroad in such manner and with such number of trains thereon, to be run at such times, as in their judgment the public interest and the interest of the party of the second part may from time to time require; to pay all taxes legally assessed upon said railroad and property, and to collect the tolls and income thereof, as full satisfaction for the managiug, operating and running of the same; and that they will at their own cost and expense, maintain the said Wilton Railroad, as well as its real estate, embankments, bridges, tracks, fences, depots, and other buildings, and all other property hereby entrusted to them, nnd return the same or similar property, in lieu of such as may be sold, destroyed, or worn out, to be then appraised by men mutually agreed upon, at the expiration of the term herein nsentioned, in absolutely as good order and condition as the same may now be, (reasonable wear and tear of buildngs or any extraordinary loss by act ot God only excepted, or make good the deficiency, in money.

And if the parties hereto shall be unable to inutually agree upon appraisers as aforesaid, each party shall name one appraiser, and the two so named shall choose a third, and the decision of said three appraiser's, or a majority of them, shall be binding upon the parties.

And the party of the second part further agrees to pay the party of the first part, in consideration of the premises anil the agreements and grants of the party of the first part, herein contained, the sum of Fourteen Thousand Dollars annually. Payment of said sum to be made at the office of the Nashua \& Lowell Railroad Corporation in the City of Nashua, one half thereof, or Seven 'Thousand Dollars, on the first day of November, and the other half or like sum, on the first day of May in each and every year during the continuance and for the time of this agreement: and also to grant to the officers for the time being of said Wilton Railroad Company, not exceeding seven in number, a fiee pass over the said Wilton Railroad, and over the Nashua \& Lowell Ruilroad, on regular passenger trains, during the continuance of this coutract, they taking all risk of personal damages, detention, or injury, or loss of baggage, from any cause whatsoever, upon said passage.

Provided, however, that if from accident or depression of business, or other adequate cause, the net earnings of the said Nashua \& Lowell Railroad as apportioned under contracts now existing, or that may hereafter, during the continuance of this agreement, exist between the 
Nashua \& Lowell and other connecting Railroad Corporations, including this agreement, be reduced in any one year from April to April, below the rate of six per cent. per annum upon its capital stock for the time being, then, and in such case, the said Wilton Railroad Company shall be entitled to receive from the Nashua \& Lowell Railroad Corporation, in lieu of the annual rent named as aforesaid, for such year, a dividend upon its capital stock, hereby nominally fixed for this purpose, at two hundred and thirty-three thousand dollars, not exceeding the net rate of per centum earned upon the said capital stock of the Nashua \& Lowell Railroad for the time being. That is to say, in no event shall the Wilton Railroad be entitled in any one year to any larger rate per cent. of earnings under this contract, upon their nominal capital, stated above, than is earned by the Nashua \& Lowell road upon its own capital stock for the time being, for the said current year, over and above all payments and contingencies.

And said party of the second part also agree to save harmless the said party of the first part from all suits, processes, and costs, expenses and damages, incident thereto, which shall arise in consequence of any accident happening on said Wilton Railroad, while in the hands of the second party, or by reason of the running of the same by them, or for any act, or neglect, or doing, of the said party of the second part; and further, to annually make all such returns and specifications to the Directors of the Wilton Railroad Company as said Directors may require in order to enable them to make all requisite reports to the Isegislature of New Hampshrre.

On the termination of this contract in 1878 , the said first party shall assume and carry out any contract made by said second party for transportation of U. S. Mails over said Wilton Railroad, which from its terms necessarily extends beyond such time ; or in case of termination of this contract from any cause, at or within said limited term, the first party shall assume and carry out for a period not exceeding one year after such termination, any and all contracts made by said second party for the transportation of freight, persons, or expresses, over said road. The income on such nail, express, freight, or passenger contracts upon said Wilton Railroad, to inure to the benefit of said first party from and after such termination.

In case the 'Treasurer of the Nashua \& Lowell Railroad is elected or appointed Treasurer of the Wilton Railroad, and shall accept said election or appointment, he shall perform all the duties appertaining thereto, at the office of the Nashua \& Lowell Railroad Co., and without charge to the said Wilton Railroad for such services or office rent. Provided, however, that he shall give to said Wilton Raılroad Co. a separate and distinct bond for the faithful performance of said duties, and the Nashua \& Lowell Railroad Co. are in no way to be accountable for his acts in such capacity.

And in case such Treasurer of the Nashua \& Lowell Railroad is offered such appointment to the office of Treasurer of the Wilton Railroad, and declines to accept the same, it shall be the duty of said party of the second part to pay such other person as may be appointed by the Wilton Railroad to the said office of Treasurer, a fair compensation for services in said office, not exceeding two hundred dollars per annum.

If any dispute shall arise from any of the provisions of this indenture, or upon any matter pertinent thereto, the same shall be submitted to the arbitration of three men; one to be appointed by each party, and the third by the two so appointed; and the decision of such men or a major part thereof, shall be binding and conclusive upon the parties.

This contract shall take effect on the first day of April, A. D., 1860, and continue in force for the term of eighteen years, unless annulled as aforesaid, or unless annulled by vote of the stockholders of either road, as hereinafter provided: it being understood and agreed that either of said corporations shall have the power to terminate the same at their first meeting, next succeeding the date hereof, and not afterwards, during its legal continuance as aforesaid, except by mutual consent. 
In witness whereof, the respective parties, by their duly authorized agents, have hereunto subscribed and affixed the seals of said corporations, this thirtieth day of May, A. D., one thousand eight hundred and sixty.

The Nashua \& Lowell Railroad Corporation by F. B. CROWNINSHIELD, E. SPALDING.

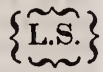

In presence of

Geo. Strark,

WM. P. Ainsworth.

The Wilton Railroad Company by

C. C. BOUTWELL. WILLIAM RAMSDELL.

\section{STA'TE OF NEW HAMPSHIRE.}

JuNe 29th, 1860.

In accordance with the laws of the State passed June, A. D., 1850, entitled an act in amendment of the laws in relation to Railroad Corporations, we hereby sunction and approve the foregoing lease for the term of five years from April 1st, 1860, to April 1st, 1865.
A. H. DUNLAP, $\left.\begin{array}{l}\text { MERRILL C.FORIST, } \\ \text { J. C. TILTON, }\end{array}\right\} \begin{aligned} & \text { Railroad } \\ & \text { Commissioners. }\end{aligned}$

Council Chamber, Concord, July 3d, 1860 . $\}$

At a meeting of the Governor and Council July 3d, 1860, the foregoing lease is approved.

ICHABOD GOODWIN, Governor.

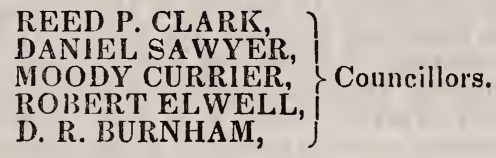




\section{STONY BROOK RAILROAD CONTRACT.}

This Indenture, made the twenty-eighth day of May, A. D., 1860, between the Stony Brook Railroad Corporation, established by the laws of the Commonwealth of Massachusetts, of the first part, and the Nashua \& Lowell Railroad Corporation, established by the laws of the Commonwealth of Massachusetts, and by the lans of the State of New Hampshire, of the second part,

WITNESSETH-

That whereas by the laws of said States, respectively, Railroad Corporations are authorized and empowered to contract with each other for the use of their roads, and for the transportation of freight, or passengers, and the conducting of all business connected therewith on their road, upon such conditions as may be mutually agreed upon, the parties hereto by virtue of such authority, did on the thirtieth day of March, one thousand eight hundred and forty-eight, enter into a contract for the operation and management of the road of the party of the first part, by the party of the second part, which contract is still in force and in full operation; and, whereas it is helieved by both parties that under certain provisions of said contract, differences and legal controversies are liable to arise, and which differences and legal controversies it is for the true interest of the parties hereto to avoid. Now, therefore, for the purpose of entering upon a more complete and satisfactory arrangement, such as the experience of the parties leads them to believe to be for their mutual advantage, and for the best interest of the public, it is hereby mutually agreed that, upon the execution and entering upon of this contract, the agreement of March, 1848, aforesaid, shall cease and terminate, and shall not be re-opened, litigated, or arbitrated, for or on account of any claim whatever of either party against the other.

And the said Stony Brook Railroad Corporation, party of the first part, in consideration of the covenants herein contained, on the part of the Nashua \& Lowell Railroad Corporation, party of the second part, to be kept and performed, and for the purposes a foresaid, doth deliver up to the said second party, their successors and assigns, and put them in full possession of the whole of their said Stony Brook Railroad, extending from the Nashua \& Lowell Railroad in North Chelmsforl, to the Fitchburg Railroad, the Worcester \& Nashua Railroad, and the Peterborough and Shirley Railroad, at Groton Junction; including all turnouts, switches, turntables, station houses, buildings, and other property, whether included in their location or not; all of which is duly inventoried and appraised by appraisers mutually agreed upon, in the schedule thereof hereunto annexed. Meaning hereby to deliver up to said Nashua \& Lowell Railroad Corporation, and put them in possession of, as aforesaid, all the property of said Stony Brook Railroad Coinpany of every description whatsoever, both real and personal, whether the same be particularly described herein or not; with the exception only of the bills, books of accounts, notes receivable, and all other debts and claims now due to the said Stony Brook Railroad Company, on its own separate account. To have and to hold the same, all and singular, to the said Nashua \& Lowell Railroad Corporation for the term of nineteen years, commencing on the first day of October, A. D., one thousand eight hundred and fifty-nine.

And the said second party may use, run, operate, manage, control, and administer the said Railroad and property of the party of the first part, as fully as said party of the first part might do-may transport freight, passengers and mails over and upon the same, and do and transact any other business authorized by the charter of sairl Stony Brook Railroad Company : and, for the purposes and objects above set forth, and in consideration of the stipulations and things herein provided to be done and performed by said second party, said party of the first part does hereby deliver: up and intrust their suid Railroad and other property to said party of the second part, for the term of nineteen years, as 
aforesaid, and do delegate to them all their powers to manage and regulate the same, and to collect tolls and income thereon, for the sole benefit of said second party.

The said first party also agree on their part to warrant and defend the said second party in the quiet possession of the said road and property, during the term aforesaid, against the claims and demands, or attempted seizure or possession of said road or property, by any and all persons, creditors or claimants, upon suits or demands against said first farty ; and at its own separate cost and expense to keep up its corporate organization and official Board of Directors, during the continuance of this agreement, and to pass and perform all such official acts as may from time to time become necessary for the legal and proper management of the road and property.

And said party of the second part, for themselves, their successors and assigns, in consideration of the premises do hereby agree for and during the term of nineteen years as aforesaid, to manage said property, to do and perform all the transportation of persons and freight, upon and over the Railroad of the party of the first part, and to furnish, manage, run and operate said Railroad at all times in a proper and suitable manner, so as to accommodate the public and the business of said road, and to collect the tolls and income thereof, as full satisfaction for the managing, operating and running of the same; and that they will at their own cost and expense maintain the said Stony Brook Railroad, as well as its real estate, embankments, bridges, tracks, depots and other buildings, and all other property hereby intrusted to them, and return the same or similar property, in lieu of such as may be sold, destroyed, or worll out, (to be then appraised by men mutually agreed upon, at the expiration of the term herein mentioned, in absolutely as good order and condition as the same may now be, (ordinary wear and tear, and loss of buildings hy fire or tornado excepted, or make good the deficiency in money. And if the parties hereto shall be unable to $\mathrm{mu}-$ tually agree upon appraisers as aforesaid, each party shall name one appraiser, and the two so named shall choose a third, and the decision of said three apprassers, or a majority of them, shall be binding upon the parties.

All taxes assessed on the said property in the manner now provided by law, are to be paid by the second party, as also any special tax on such property, over and above the property-tax upon the Stockholders. But in case the Legislature shall levy a tax upon the Stony Brook Railroad, in lieu of the tax now assessed upon the Stockholders, the same shall be pard by the first party.

And the party of the second part further agrees to pay the party of the first part, in consideration of the premises and agreements, and grants of the party of the first part herein contained, the sum of Seventeen Thousand and Seven Hundred dollars annually. Payment of said sum to be made at the office of the Nashua \& Lowell Railroad Corporation, in the City of Nashua, one half thereof, or Eight Thousand Eight Hundred and Fity Wollars, on the first day of May, and the other half or like sum on the first day of November, in each and every year during the continuance, and for the time of this agreement. And also to grant to the officers for the time being of said Stony Brook Railroad Company, not exceeding seven in number, a free pass over the said Stony Brook Railrnad and over the Nashua \& Lowell Railroad, on regular passenger trains, during the continuance of this contract, they taking the risk of all personal damage, detention, or injury or loss of baggage, Irom any cause whatsoever upon said passage.

And said party of the second part also agree to save harmless the said party of the first part, from all suits, processes and costs, expenses and damages incident thereto, which shall arise in consequence of any accideut happening on said Stony Brook Railroad. while in the hands of the second party, or by reason of the running of the same by them, or from any act or neglect or doing of the said party of second part: and further, to annually make all such returns and specifications to the Directors of 
the Stony Brook Railroad Company, as said Directors may require in order to enable them to make all requisite reports to the Legislature of Massachusetts.

On the termination of this contract, the said first party shall assume and carry out, for a period not exceeding one year after such termination at the time aforesaid, any and all contracts made by said secorid party, for the transportation of mails, persons, expresses or freight, over said road. The income from such contracts upon said Stony Brook Road to inure to the benefit of said first party, from and after such termination.

This contract shall relate back and take effect upon and from the first day of October, A.D., 1859, and continue in force for the term of nineteen years thereafter, unless annulled by a vote of the Stockholders of either road as hereinafter provided; it being understood and agreed that either of said Corporations shall have the power to terminate the same at their first annual meeting next succeeding the date hereof, and not afterwards, and in case either Corporation shall so annul the same, then by such act the original contract of March 1848 a foresaid shall he fully revived, and the Stony Brook Railroad shall be run and operated by the Nashua \& Lowell Railroad Corporation, under the provisions of the same, for the full term therein provided.

If any dispute shall arise from any of the provisions of this indenture, or upon any matter pertinent thereto, the same shall be submitter to the arbitration of three men; one to be appointed by each party, and the third by the two so appointed; and the decision of such men, or a major part thereof, shall be binding and conclusive upoti the parties.

In witness where of the said parties have, by their committees duly nuthorized thereto, hereunto subscribed and affixed the respective seals of said Corporations, this twenty-eighth day of May, A. D., 1860.

Stony Brook Railroad Corporation, by their Committee,

TAPPAN WENTWOR'TH, JOHN WRIGH'T, SEIVALL G. MA'CK.

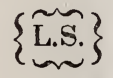

Witness :

Tim. G. TwEed, JR.,

Mial C. Farnswortu.

The Nashua \& Lowell Railroad Corporation, by their Committee, DANIEL S. RICHARDSON, $\{\widetilde{\text { L.S. }}\}$
J. G. ABBOT'T.

\section{COMMONWEALTH OF MASSACHUSETTS.}

Middesex, Ss., May 28th, 1860.

Then Tappan Wentworth, John Wright and Sewall G. Mack persol]ally appeared and acknowledged the foregoing instrument to be the free act and deed of the Stony Brook Railroad Corporation.

ANDREW F. JEWETr, Justice of the Peace. 


\section{Twenty-Third}

\section{ANNUAL REPORT}

()) Tris

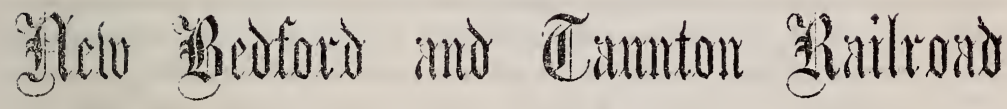

\section{(OMPANY.}

\section{TAUNTON:}

c. A. HACK'S BOOK PRESA, JNION BLOCK.

1861. 


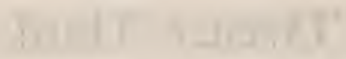

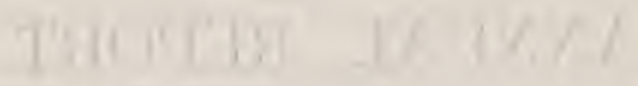

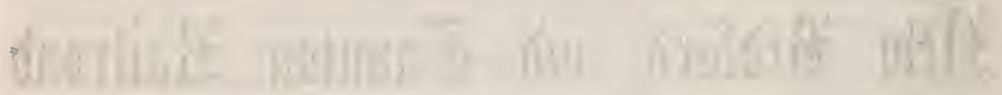

$$
\text { Barowaki }
$$

- Brikathi

$$
\text { - } x y+
$$




\section{Ementn=(C)iro Innual Report}

OF NII

\section{NEW BEDFORD AND TAUNTON R. R.}

\section{COMPANY.}

Report of the Directors of the $\mathrm{New}$ Bedford and Taunton Railvoad, for the year endixg Nov. 30, 1861, including the Fuirhaven Branch Railioad for 5 months, purchased. July 1, 1861, under the provisions of the 80th chapter of the Acts of the Legislature, of the year 1861 .

Capital Stock,

Increase of Capital since last Report . . .

Capital paid in per last report, . . . , ,

Capital paid in since last report,
Total amount of Capital Stock paid in,

Number of shares of Capital Stock issued,

Funded debt, per last report,

Funded debt paid, since last report,

Funded debt, increase of, since last report,

Total present amount of funded debt,

Floating debt, per last report,

Floating debt, increase of, since last report,

Total present amount of floating debt,
Total present amount of funded and floating debt,

Naximum amount of debts during the year,

Average rate of interest per annum, paid during the year,

\section{COST OF ROAD AND EQUIPMENT.}

For graduation and masonry, per last report,

For graduation and masonry, paid during the past

Total amount expended for graduation and masonry,

\section{For wooden bridges, per last report,}

For wooden bridges, paid during the past year,

Total amount expended for wooden bridges,

Total amount expended for iron bridges, (if any,)

For superstructure, including iron, per last report,

For superstructure, including iron, paid during the past year,

$\$ 500,00000$

5000

500,00000

213,00000

213,00000

18,60000

89,90000

108,50000

321,50000

333,500 00

6 per cent.

158,10801

5,10385

158,10801

5,10385

149,54800 


\section{NEW BEDFORD AND TAUNTON R. R.}

Total amount expended for superstructure, including iron,

For stations, buildings, and fixtures, per last report,

for stations, buildings, and fixtures, paid during the past year, jound for stations, buildings and fixtures,

For land, land damages, and fences, per last report,

For land, land damages, and fences, paid during the past year,

Total amount expended for land, land damages, and fences,

For locomotives, per last report,

For locomotives, paid during the past year,

Total amount expended for locomotives,

For passenger and baggage cars per last report,

For passenger and baggage cars, paid during the past year,

Total amount expended for passenger and baggage cars,

For merchandise cars per last report

For merchandise cars paid during the past year, .

Total amount expended for merchandise cars, .

For engineering per last report,

For engineering paid during the past year, . .

Total amount expended for engineering, . .

For agencies and other expenses per last report, .

For agencies and other expenses paid during the past year,

Total amount expended for agencies and other expenses,

Total cost of road and equipment,

Amount of assets of property held by the corporation in addition to the cost of the road,

\section{CHARACTERISTICS OF THE ROAD.}

Length of road,

Length of single main track,

Length of double main track,

Length of branches owned by the Company, stating whether they have a single or double track,

Aggregate length of sidings and other tracks, excepting main tracks and branches,

Weight of rail per yard, in main road

Weight of rail per yard, in branch roads,

Specify the different weights per yard,

Maximum grade, with its length, in main road,

Maximum grade, with its length, in branch roads,

Total rise and fall in main road, .

Total rise and fall in branch roads,

Shortest radius of curvature, with length of curve, in main road,

Shortest radius of curvature, with length of curve in branch roads,

57,74915

$149,5+804$

32145

92,42159

58,07060

17,00646

1,67097

15,16128

1,46774

$16,6290 \cdot 2$

18,42500

48250

18,90750

15,69397

15,69397

19,94473

$19,9447: 3$

553,01470

20 13-100 miles.

20 13-100 miles.

7,731 feet; single track.

5,647 feet.

50 lbs.

$56 \mathrm{lbs}$.

$40 \mathrm{ft}$. per m. for $1 \frac{1}{2}$ miles. $65 \mathrm{ft}$. per mile; $600 \mathrm{ft}$. 361 feet.

20 feet.

1906 feet in 1100 feet.

250 feet in 300 feet. 
Total degrees of currature, in main road,

Total degrees of curvature in branch roads,

Total length of straight line in main road,

Total length of straight line in branches, Aggregate length of woolen truss bridges, Aggregate length of all other wooden bridges, Aggregate length of iren bridges,

Whole length of road infenced on both sides,

Number of public ways crossed at grade,

Number of railroads crossed at grade,

liemarks,

Way stations for express trains,

Way stations for accommodation trains,

Flag stations,

Whole number of way stations,

Whole number of flag stations,

\section{DOINGS DURING THE YEAR.}

Miles run by passenger trains,

Miles run by freight trains

Miles run by other trains,

'Total miles run, [See note at end of report.]

Number of passengers carried in the cars,

Number of passengers carried one mile,

Number of tons of merchandise carried in the cars,

Number of tons of merchandise carried one mile,

Number of passengers carried one mile to and from other roads,

Number of tons earrierl one mile to and from other roads,

Rate of speed adopted for express passenger trains, including stops,

Arerage rate of speed actually attained by express passenger trains, including stops and detentions, .

Rate of speed adopted for accommodation trains,

Rate of speed actually attained by accommodation trains, including stops and detentions,

Average rate of speed actually attained by special trins, inchiding stops and detentions,

Average rate of speen adopted for freight trains, includstops and detentions,

Wistimated weight in tons, of passenger cars, (not including passengers,) haxled one wile,

Fstimated weight in tons, of merchandise cars, (not including freight,) hanled one mile,

\section{EXPENDITURES FOR WORKING THE R()AD.}

Nor repairs of road, maintenance of way, exclusive of wooden bridges and renewal of iron,

For repairs of wooden bridges,

For wages of switchmen, average per month,

For wages of gate-keepers, average per month,

For wages of signal men, average per month,

For wages of watchmen, average per month,
160 degrees.

87 degrees, $45 \mathrm{~min}$.

$17 \frac{3}{4}$ miles.

281 feet.

13,995 feet.

19

1

1.

6.

1.

6.

37,108

14,350

62

51,520

96,612

$1,329,871$

36,445 tons, $\quad 26 \mathrm{lbs}$

$\$ 20,638$ « 1,913 .

$1,035,611$

332,355 tons, 431 lis

24 miles per hour.

24 miles per hour.

15 miles por hour.

$\$ 37.50$

10.00

6.00

40.00
12,17229

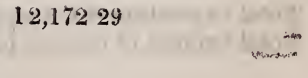

2,43324 
- Number of men employed, exclusive of those engaged in construction,

For removing ice and snow, (this item to include all labor, tools, repairs, and extra steam power used,

For repairs of fences, gates, houses for signal-men, gate keepers, switchmen, tool-houses,

Total for maintenance of way,

116

\section{MOTIVE POWER AND CARS.}

For repairs of locomotives,

For new locomotives, to cover depreciation, :

For repairs of passenger cars, . . . .

For new passenger cars to cover depreciation, .

For repairs of merchandise cars, . . .

For new merchandise cars to cover depreciation, :

For repairs of gravel and other cars,

Total for maintenance of motive power and cars .

Number of engines,

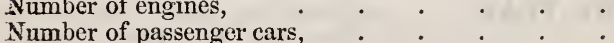

Number of baggage cars, $\quad . \quad \cdot \quad \cdot \quad \cdot \quad \cdot \quad \cdot$

Number of merchandise cars, $: \quad: \quad . \quad$.

Number of gravel cars, . $. \quad . \quad . \quad . \quad$.

\section{MISCELLANEOUS.}

Eor fuel used by engines during the year, viz:-

Wood and Coal, cost of the same,

For Stations, Cars, Machine shop, \&c.,

For oil used by cars and engines,

For waste and other material for cleaning,

For salaries, wages, and incidental expenses, chargcable to passenger department, .

For salaries, wages and incidental expenses, chargeable to freight department,

for gratuities and damages, $\quad: \quad \cdot \quad \cdot \quad \cdot \quad \cdot \quad \cdot$

For taxes and insurance, $\quad \cdot \quad \cdot \quad \cdot \quad \cdot \quad:$

\section{For ferries,}

For repairs of station buildings, aqueducts, fixtures, and furniture, .

For renewals of iron, including laying down, .

For new iron laid down during the year, dedacting the value of old rail taken up,

For amount paid other companies, in tolls for passengers and freight carried on their roads, specifying each company, Taunton Branch Rail Road Co.,

For amount paid other companies, as rent for use of their roads, specifying each company,

For salaries of president, treasurer, superintendent, law expenses, office expenses of the above offices and all other expenses not included in any of the foregoing items,

Total Miscellaneous,

Total expenditures for working the road,

Total amount of interest paid during the year,

3,57576

1,86636

2,21173

8

17

5

$\{10,19868$

1,85654

8,49086

8,70847

66086

66627

25052

39,68927

5,32780

75,84927

98,10865 


\section{NEW BEDFORD AND TAUNTON R. R.}

\section{INCOME DURING THE YEAR.}

Tieceived from Taunton Branch Rail Road Co., under agrecment with them,

For Passengers :-

1. On main road, including branches owned by company,

2. To and from other roads, specifying what Old Colony and Fall River, Taunton Branch and Middleboro' and 'Taunton,

For Freight :-

1. On main road and branches owned by company,

2. To and from other connecting roads,

U. S. Mails,

Rents, $\$ 855^{\circ}$ Income of Fairhaven Br., $\$ 69346^{\circ}$

Total income, . . . .

Net earnings after deducting expenses, . . .

\section{DIVIDENDS.}

2 Per cent. Tetal Surplus not divided, Surplus last year, Total surplus,
3,60135

9,56331

62,91206

6,57050

36,31610

2,50375

1,54881

123,01588

23,23940

10,00000

13,23940

38,10262

\section{ESTIMATED DEPRECIATION BEYOND THE RENEWALS, viz :-}

Roads and bridges, .

Buildings,

Engines and cars,

\section{MORTGAGE DEBTS.}

Amount of debts, secured by mortgage of road and franchise, or any property of the Corporation, per last report,

Mortgage debt, paid since last report,

Increase of mortgage debt, since last report,

Present amount of mortgage debt,

Number of mortgages on road and franchise, or any property of the Corporation, 
COST OF FAIRHAVEN BRANCH ROAD AND EQUIPMENT.

For graduation and misunry, per last report,

For graduation and masonry, paid during the past year,

Total amount expended for graduation and masoiry,

For wooden bridges, per last report,

For wooden bridges, paid during the past year,

Total amount expended for wooden bridges,

'Total amount expended for iron bridges, (if any,)

For superstructure, including iron, per liast report,

For: superstructure, including iron, paid during the past year,

Total amount expended for superstructure, inclinding iron,

For stations, buildings and fixtnres, per last report,

For stations, buildings and fixtures, paid during the past year,

Total amount expended for stations, buildings and fixtures,

For land, land damages, and fences, per last report,

For land, land damages and fences, paid during the past year,

Total amount expended for land, land damages, and fences,

For locomotives, per last report,

For locomotives, paid durino the past year,

Total amount expended for locomotives, .

For passenger and baggage cars, per last report .

For passenger and baggage cars, paid during the past year,

Total amount expended for passenger and baggage cars

For merchandise cars per last report,

For merchandise cars, paid during the past year,

Total amount expended for merchandise cars, .

For engineering, per last report,

For engineering, paid during the past year, . .

Total amount expended for engineering, .

For agencies and other expenses, per last report, .

For agencies and other expenses, paid during the past year,

Total amount expended for ageneies and other expenses,

Total cost of road and equipment,

Amount of assets of property held by the corporation in addition to the cost of the road,

Ferry-boat and slips,

Two wharves,

Real estate.
71,71003

71,71009

1,07380

1,07380

$8 \pi, 29412$

87,29412

19,125228

19,05228

17,30700

17,30700

17,00000

17,00000

7,35000

7,35000

7,30000

7,30000

5,12812

5,12812

18,91921

18,91921

252,13462

33,38189

11,98349

$\begin{array}{ll}2,50000 & 47,86538\end{array}$ 


\section{CHARACTERISTICS OF THE FAIRUAVEN \\ BRANCH ROAD.}

Length of road,

Length of single main track,

Length of double main track, . . . . .

Length of branches owned by the Company, stating whether they lave a single or donble track,

Aggregate length of sidings and otler tracks, excepting main tracks and branches,

Weight of rail per yard, in main road,

Weight of rail per yard, in branch roads,

Specify the different weights per yard,

Maximum grade, with its length, in main road,

Maximum grade, with its length, in branch roads,

Total rise and fall in main road,

Total rise and fall in branch roads,

Shortest radius of curvature, with length of curve, in main road,

Shortest rarlius of curvature, with length of curve in branch roads,

Total degrees of curvature, in main roail

Total degrees of curvature in branch roads,

Total length of straight line in main road,

'Total length of straight line in branches,

Aggregate length of wooden truss bridges,

Aggregate length of all other wooden bridges,

Agmiegate length of iron bridges,

Whote length of road unfenced on both sides, .

Number of public ways crossed at grade,

Number of railroads crossed at grade, . . .

liemarks,

Way stations for express trains,

Way stations for accommodation trains, . . .

Flag stations,

Whole number of way stations,

Whole number of flag stations,

\section{1)OINGS DURING FIVE MONTHS ON FAIR- HAVEN BRANCH ROAD.}

Miles run by passenger trains,

Miles run by freight trains

Miles run by other trains,

Total miles run,

Number of passengers carried in the cars,

Number of passengers carried one mile,

Number of tons of merchandise carried in the cars,

Number of tons of merchandise carricd one mile,

Number of passengers carried one mile to and from other roads,

Number of tons carried one mile to and from other roads,
15 11-100 miles.

15 11-100 miles.

68-100 miles.

56 lbs.

24. $24-100 \mathrm{ft}$, in $126-100 \mathrm{~m}$

$52 \frac{1}{2}$ feet.

1720 feet in 1801 feet.

260 degrees, $55 \mathrm{~min}$.

$1256-100$ miles.

110 feet.

22

2.

2.

15,129

188,665

3,114 tons,

44,716

96,805

43,015 tons, 


\section{NEW BEDFORD AND TAUNTON R. R.}

Rate of speed adopted for express passenger trains, including stops, .

A rerage rate of speed actually attained by express passenger trains, including stops and detentions,

Rate of speed adopted for accommodation trains,

Rate of speed actually attained by accommodation trains, including stops and detentions,

Average rate of speed actually attained by special trains, including stops and detentions,

Average rate of speed adopted for freight trains, includstops and detentions,

Estimated weight in tons, of passenger cars, (not including passengers,) hauled one mile

Estimated weight in tons, of merchandise cars, (not including freight,) hauled one milc,

\section{EXPENDITURES FOR WORKING THE FAIR-}

\section{HAVEN BRANCH ROAD, FIVE MONTHS.}

For repairs of road, maintenance of way, exclusive of wooden bridges and renewal of iron,

For repairs of wooden bridges,

For wages of switchmen, average per month,

For wages of gate-keepers, average per month,

For wages of signal men, average per month,

For wages of watchmen, average per month,

Number of men employed, exclusive of those $\quad 30.00$

For removing ice and snow, (this item to include all labor, tools, repairs, and extra steam power used,

For repairs of fences, gates, houses for signal-men, gate keepers, switchmen, tool-houses,

Total for maintenance of way, . . . .

\section{MOTIVE POWER AND CARS. FAIRHAVEN} BRANCH, FIVE MONTHS.

For repairs of locomotives,

For new locomotives, to cover depreciation,

For repairs of passenger cars,

For new passenger cars to cover depreciation,

For repairs of merche

For new merchandise cars to cover depreciation.

For repairs of gravel and other cars,

Total for maintenance of motive power and cars .
28 miles per hour.

28 miles per hour.

15 miles per hour.

3,39438

37100

32

3,76538

52411

41945

38430

300

1,33086 


\section{MISCEJLANEOUS. FAIRHAVEN BRANCH,} FIVE MONTHS.

For fuel used by engines during the year, viz:-

Wøod, number of cords, 112. Cost of the same,

Coal, number of tons, (reckening 2,240 lbs. to the ton,) 105. Cost of coal,

Coal used for Ferry Boats and Stations, 348 tons,

For oil used by cars engines, and shops,

For waste and other material for cleaning,

For salaries, wages, and incidental expenses, chargeable to passenger department, .

For salaries, wages and incidental expenses, chargeable to freight department,

For gratuities and damages, : $\quad: \quad \cdot \quad \cdot \quad$ :

For taxes and insurance, . . . . .

For ferries,

For repairs of station baildings, aqueducts, fixtares, and furniture,

For renewals of iren, including laying down, : :

For new iron laid down during the ycar,

Wor amount paid other companies, in tolls for passengers and freight carried on their roads, specifying each company, Cape Cod Rail Road Co.,

For amount paid other companies, as rent for use of their roads, specifying each company,

For salaries of president, treasurer, superintendent, law expenses, office expenses of the above offices and all other expenses not included in any of the foregoing items,

Total Miscellaneous,

Total expenditures for working the road,

Total ameunt of interest paid during five months,

\section{3




\section{NEW BEDFORD AND TAUNTON R. R.}

INCOME ON FAIRHAVEN BRANCH, DURING IIVE MONTHS.

\section{For Passengers:-}

1. On main road, including bianches owned by company,

2. 'To and from other roads, specifying what, . For Freight:-

1. On main road and branches owned by company,

2. To and from other connectirg roads,

U. S. Mails,

Rents, $\$ 28854$ Ferry, $\$ 1,76600$.

Total income, . $\quad . \quad . \quad . \quad$.

Net earnings after deducting expenses, . . .

JOSEYH GRINNELE, T. MANDELL, GEO. HOWLAND, JR., WARD M. PARKER, CHARLES L. WOOD, T. S. HATHAWAY, D. R. GREENE,

29,19174
1,70516

$17,4,2235$

18635

7,11501

$\therefore 0833$

2,05454

\section{6}

Directors of the N. Besiford \& Tawnton R. R. Corporation.

Bristor ss. December 25th, 1861 . Then personally appeared Joseph Grinnell; T. Mandell, Geo. Howland Jr., W. M. Parker, Charles L. Wood, Thos. S. Hathaway, and D. R. Greene, and severally made oath or affirmation to the truth of the foregoing statement, by them subscribed.

Before, Thomas M. James, Justice of the Peace.

The Cars and Engines on the New Bedford and Taunton Rail Road, are owned by the Corporation, in common with the Taunton Branch Rail Road Corporation, and the two roads are operated at their joint expense.

In addition to the number of miles run on the New Bedford and Taunton Rail Road, the Passenger Cars belonging to this Corporation and the Taunton Branch Rail Road have run on the Boston and Providence Pail Road, 38,864 miles, of the expense of which, this Corporation has paid 20-31 parts ; and the Freight Cars, belongjointly to this Corporation and the Taunton Branch Rail Road, have run on the Boston aud Providence Rail Road, 29,948 miles, of the expense of which, this Corporation has paid 48 per cent.

JULy 9TH, 1861. J. F. Gerald was thrown from carriage, by collision with Locomotive, and severely injured. 
For engineering, paid during the past year.........

Total amount expended for engineering.............

For agencies and other expenses, per last Report ...

For agencies and other expenses, paid during the past year....

Total amount expended for agencies and other expenses.................................

Total cost of road and equipment..............

Amount of assets or property held by the corporation in addition to the cost of road................

Nothing.

91,67655

13,20532

10000

\section{Characteristics of Road.}

Length of road.........................

Length of single main track....................

Length of double main track....................

Length of branches owned by the Compariy, stating whether they have a single or double track.......

Aggregate length of sidings, and other tracks, excepting main track and branches...............

Weight of rail per yard, in main road.............

Weight of rail per yard, in branch roads, (specify the different weights per yard, $). \ldots \ldots \ldots \ldots \ldots \ldots$.

Maximum grade, with its length, in main road......

Maximum grade, with its length, in branch roads...

Total rise and fall in main road...............

Total rise and fall in branch roads................

Shortest radius of curvature, with length of curve, in main road............................

Shortest radius of curvature, with length of curve, in branch roads............................

Total degrees of curvature in main road.............

Total degrees of curvature in branch roads........

Total length of straight line, in main road...........

Total length of straight line, in branches...........

Aggregate length of wooden truss bridges......... .

Aggregate length of all other wooden bridges.......

Aggregate length of iron bridges..................

Whole length of road unfenced on both sides........

Number of public ways crossed at grade..... ......

Number of railroads crossed at grade.............

Remarks: .................................

Way stations for express trains...................

Way stations for accommodation trains...........

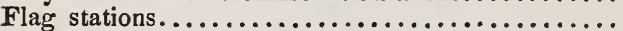

Whole number of way stations..................

Whole number of flag stations...................

DoINGS DURING THE Year.

Miles run by passenger trains.................

Miles run by freight trains.....................

Miles run by otler trains...........................

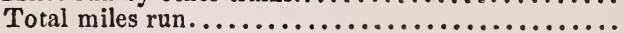

Number of passengers carried in the cars.............

Number of passengers carried one mile............

Number of tons of merchandise carried in the cars..

Number of tons of merchandise carried one mile....

Number of passengers carried one mile, to and from

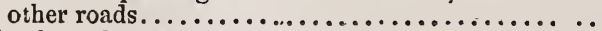

Number of tons carried one mile, to and from other roads.

Rate of speed adopted for express passenger trains, including stops...........................

Average rate of speed actually attained by express passenger trains, including stops and detentions...

26 miles, 5,168 feet. 26 miles, 5,168 feet.

None.

None.

12,646 feet.

50 lbs.

None.

$55 \mathrm{ft}$. for $3,000 \mathrm{ft}$.

None.

430 feet.

None.

$695 \mathrm{ft}$. curv., length $1100 \mathrm{ft}$ 。

None.

$790^{\circ}$.

None.

20 miles, $1172 \mathrm{ft}$.

None.

None.

$415 \mathrm{ft}$.

None.

All fenced.

33

1

11

$91,776 \quad 55$

597,38633

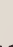

The road has been opers ated by the Boston and Maine Railroad, under Lease. 
Rate of speed adopted for accommodation trains.... Rate of speed actually attained by accommodation trains, including stops and detentions.

Average rate of speed actually attained by special trains, including stops and detentions............

Average rate of speed adopted for freight trains, in-

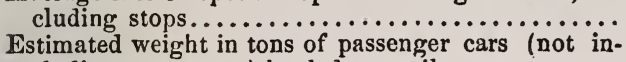
cluding passengers) hauled one mile.............

Estimated weight in tons of merchandise cars (not including freight) hauled one mile..............

\section{Expenditures for Working the Road.}

For repairs of road, maintenance of way, exclusive of wooden bridges and renewals of iron.............

For repairs of wooden bridges.................

For wages of switchmen, average per month. $\$$. ;

For wages of gate-keepers, average per month, $\$$

For wages of signal-men, average per month, $\$$. For wages of watchmen, average per month, $\$ .$. Number of men employed, exclusive of those en-

For removing ice and snow, (this item to include all labor, tools, repairs, and extra steam power used)..

For repairs of fences. gates, houses for signal-men, gate-keepers, switchmen, tool houses............

Total maintenance of way......................

\section{Motive Power and Cars.}

For repairs of locomotives................... For new locomotives, to cover depreciation.......... For repairs of passenger cars................. For new passenger cars, to cover depreciation....... For repairs of merchandise cars................. For new merchandise cars, to cover depreciation.... For repairs of gravel and other cars............. Total for maintenance of motive power and cars.... Number of engines........................ Number of passenger cars...................... Number of baggage cars. . . . . . . . . . . . . . . . . .

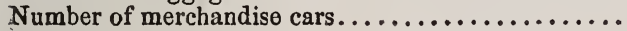

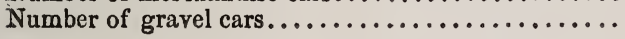

\section{Miscellaneots.}

For fuel used by engines during the year, viz: Wood, number of cards . Cost of the same... Coal, number of tons, (reckoning 2,240 lbs. to the

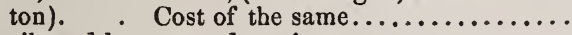
For oil used by cars and engines.................. For waste and other material for cleaning........... For salaries, wages and incidental expenses, charge able to passenger department................. For salaries, wages, and incidental expenses, chargeable to freight department...................

For gratuities and damages.....................

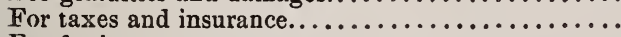

For ferries...............................

For repairs of station buildings, aqueducts, fixtures,

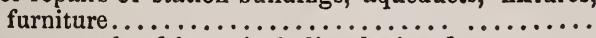
For renewals of iron, including laying down....... For new iron laid down, deducting the value of old iron taken up...........................

For amount paid other companies, in tolls for pas- 
sengers and freight carried on their roads, specifying each company........................

For amount paid other companies, as rent for the use of their roads, specifying each company ..........

For salaries of president, treasurer, superintendent, law expenses. offic expenses for the above offices, and all other expenses not included in the forego-

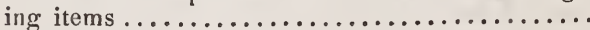

Total miscellaneous ..........................

Total expenditurcs for working the road...........

Total amount of interest paid during the year......

\section{INCOME DURING THE YEAR.}

For Passengers :-

1. On main road, including branches owned by company .............................

2. To and from other roads, specifying what........ For Freight:-

1. On main road and branches owned by companp. .

2. To and from other connecting roads............

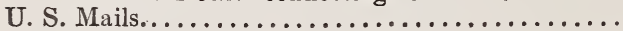

Rents................................

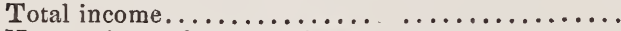

Net earnings after deducting expenses..........

\section{Dividends.}

- per cent. Total.

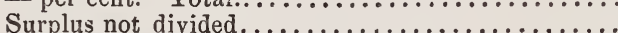

Surplus last year...........................

Total surplus..

\section{Estimated Depreciation beyond the Renew-} ALS, VIZ:

Of roads and bridges.....................

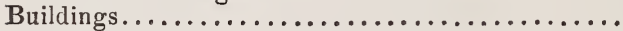

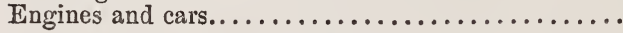

\section{Mortgage Debts.}

Amount of debt secured by mortgage of rôad and franchise, or any property of the corporation, per

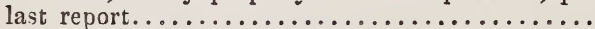
Mortgage debt paid since last report............. Increase of mortgage debt since last report......... Present amount of mortgage debt............... Number of mortgages on road and franchise, or any property of the corporation.

The Funded Debt is Bonds secured by Mortgage.

\section{GEORGE J. TENNEY, \\ W. N. CLEA VELAND, \\ SAMUEL LITTLE, EDWARD KIMBALL,}

Directors of the Newburyport Railroad Corporation,

Georgetown, Dec. 16, 1861. Essex, ss. Then personally appeared George J. Tenney, W. N. Cleaveland, Samuel Little, and Edward Kimball, and severally made oath to the truth of the foregoing statement by them subscribed.

Before me,

GEO. COGSWELL, Justice of the Peace. 


\title{
R E P O R T
}

\section{TRUSTEES}

\section{Mlew-fondon, Millintantic and plalmer}

\author{
RAILROAD COMPANY,
}

From Dec, I, 1860, to April 1, 1861.

NEW-LONDON :

STARR \& FARNHAM, PRINTERS, COR. STATE ANDD MAIN STS.

1861. 



\section{R E'I U R N}

OF THE

\section{TRUSTEES}

\section{OF THE NEW-LONDON, WILLIMANTIC AND PALMER R. R. CORPORATION.}

Return of the Trustees New.London, Willimantic and Palmer Raitroad Corporation, required by the Acts of. Mass. Chap. 63, Sec. 132, 135.

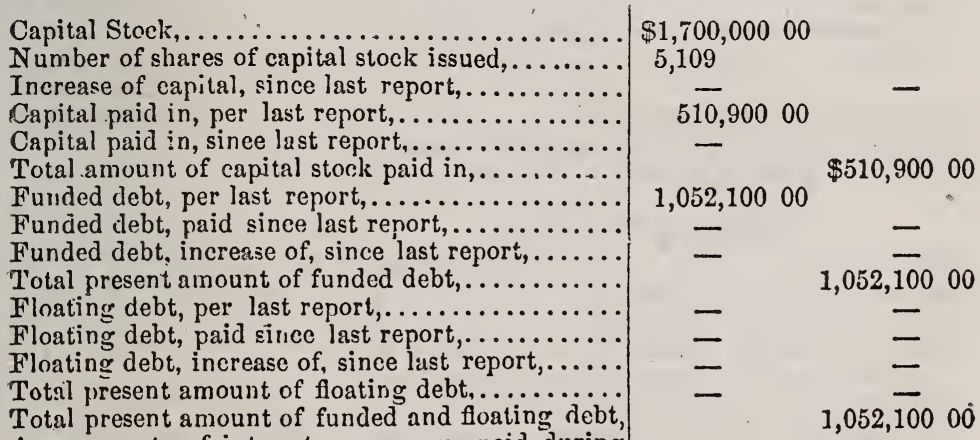

Average rate of interest per annum, paid during

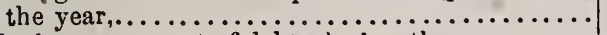
Maximum amount of debts during the year,.....

Cost of Road and EQuipuent.

For graduation and masonry, per last report,..... For graduation and masonry, paid during past year Total amount expended for graduation \& masonry, Fur wonden bridges, per last report,........... For wooden bridges, paid during the past year,.. Total amount expended for wonden bridges,..... Total amount of iron bridges (if any,)........... For superstructure, including iron, por last report,
$\$ 1,700,00000$

5,109

$5 \overline{10,900} 00$

No interest paid.

$\$ 412,49144$

84,96508

$\$ 412,491 \quad 44$

$84, \overline{965} 08$

406,97320 
For superstructure, including iror, paid Juring the

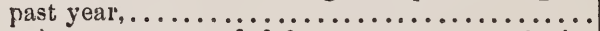

Total amuunt expended for superstructure, inclu.

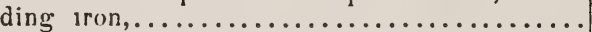

For stations, buildings and fixtures, per last report,

For stations, buildings and fixtures, paid during the

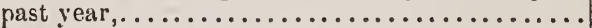

Total amount expended tor stations, buildings and

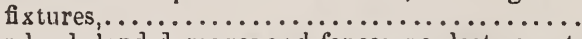

For land, land damages and fences, per last report,

For land, land damages and fences, paid during

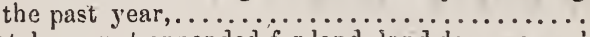

Total amount expended for land, Jand damages and

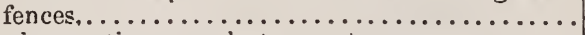

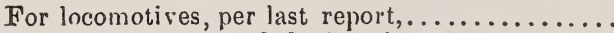

For locomotives, raid during the past year,......

Total amount expended for locomotives,.........

For passenger and baggage cars, per last report,..

For passenger and baggage cars, paid during the

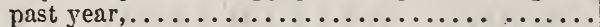

Total amount expended for passenger and baggage

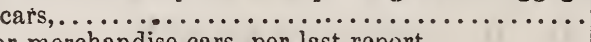

For merchandise cars, per last report,...........

For mercluandise cars, paid during the past year,

Total amount expended for merchandise cars,....

For engineering, per last report................

For engineeering, paid during the past year,.....

Total amcunt expended for engineering..........

For agencies and other expenses, per last report,...

For agencies and other expenses, paid during the

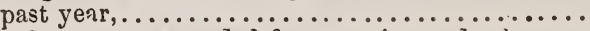

Total amount expended for agencies and other ex.

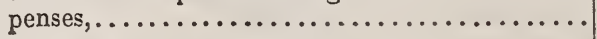

$\$ 85,22180$

$\$ 406,97320$

199,36298

85,22180

115,58374

199,36298

$115, \overrightarrow{583} 74$

58,57487
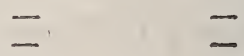

$207,215 \quad 53$

Total cost of rond and equipment,............

Amount of assets or property held by the corporation in addition to the cost of the road,........

\section{Characteristics of Road.}

Length of road,............ (9 miles in Mass.)

Length of single main track,.................

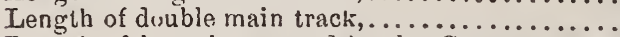

Length of branches owned by the Company, stating whether they have a single or double track,

- Aggregate length of sidings and other tracks, excepting main tracks and branches, ...........

Weight of rail, per yard, in main road, ............

Weight of rail, per yard, in branch road,..........

Specify the different weights, per yard,..........

Maximum grade, with its length, in main road,...

Maximum grade, with its length, in branch roads,

Total rise and fall in main road,..............

Total riss and fall in branch roads,................

Shortest radius of curvature, with length of curve, in main road,.........................

Shortest radius of curvature, with length of curve,

in branch roads.........................

Total degrees of curvature in main road,..........

Total degrees of curvature in branch roads,......

66 miles total.

$\$ 1,573,56864$

About 5 miles.

$56 \mathrm{lbs}$.

66 feet.

$1,0 \overline{85}$ feet.

$293^{\circ}-400$ foet long. 
Total length of straight line, in main road,....... Total length of straight line, in branches,....... Aggregate length of wooden truss bridges,....... A ggregate iength of all other wooden bridges,.... A ggregate length of iron bridges, ............... Whole length of road unfenced on both sides,.... Number of public ways crossed at grade,........ Number of railroads crossed at grade,............

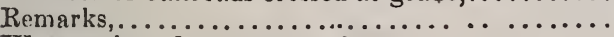
Way stations for express trains,................ Way stations for accommodation trains,.........

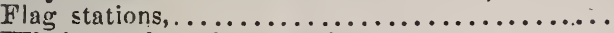
Whole number of way stations, ..............

Whole number of flag stations, .................

\section{Doings During Four Months.}

Miles run by passenger trains, . . . . . . . . . . .

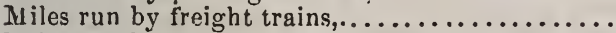
Miles run by other trains,.$\ldots \ldots \ldots \ldots \ldots \ldots \ldots$.

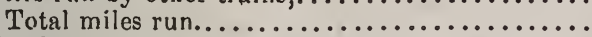
Number of prassengers carried in the cars,......... Number of passengers carried one mile,......... Number of tons of merchandise carried in the cars, Number of tons of merchandise carried one mile,. Number of passengers carried one mile, to and from

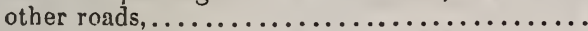

Number of tons carried one mile, to and from oth. er roads,

Rate of speed adopted for express passenget trains,

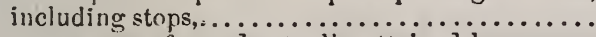

A verage rate of speed actually attained by express passenger trains, including stups and detentions, Rateo of speed adopted for accominodation trains,.. Rate of speed actually attained by accommodation trains, includirg stops and detentions..........

Average rate of speed actually attained by special trains, including stons and detentions...........

A verage rate of speed adopted for freight trains, including stops and detentions...............

Estimated weight in tons of passenger cars, (not including passengers, ) hauled one mile,........

Estimated weight in tons of merchandise cars, (not including freight, ) hauled one mile,...........

\section{Expenditures for Working the Road.}

For repairs of road, maintenance of way, exclusive of wooden bridges, and renewals of iron,......

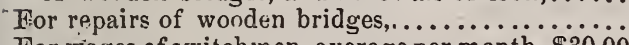
For wages of switchinen, averəge per month, $\$ 3000$ For wages of gate-keepers, average per $m$ 'th, $\$$ For wages of signai-men, a verage per month, $\$ 3000$ For wages of watchmen, average per month, $\$ 3000$ Number of men employed, exclusive of those en-

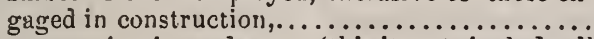

For removing ice and snow, (this item to include al) labor, tools, repairs, and extra steam rower used.. For repairs of fences, gates, houses for signal men, gate. keepers, switclimen, tool houses, ..........

Total for maintenance of way, ...............

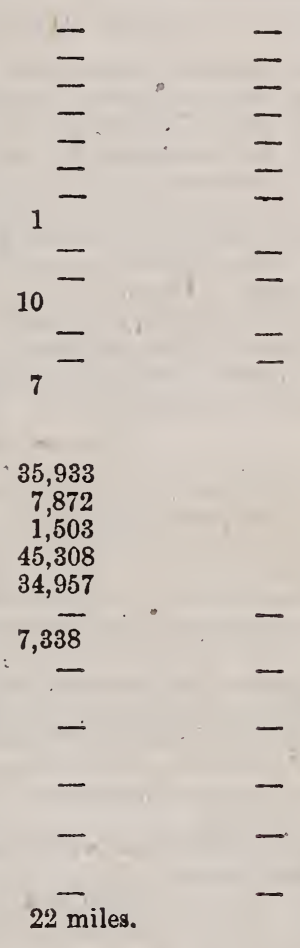

\section{5 miles.}

20 miles.

12 miles. 


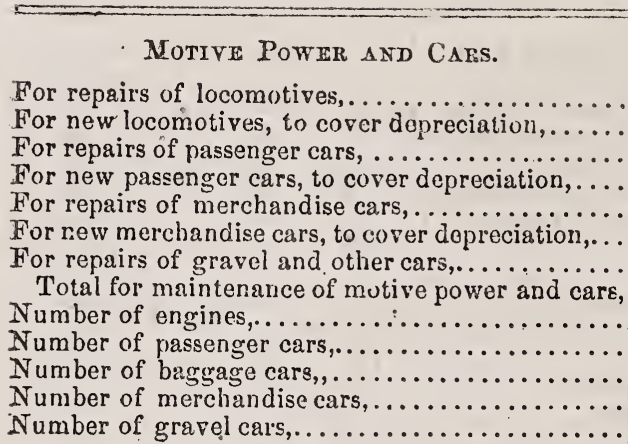

\section{Miscellaneous.}

For fuel used by engines during the year, viz:Wood, number of cords. Cost of the same. Coa!, number of tons, (reckoning 2,240 $\mathrm{tbs}$, to the ton.) - Cost of coal.

For oil used by cars and engines,.....................

For waste and other material for cleaning........

For salaries, wages and incidental expenses, chargeable to passenger department,................

For salaries, wages and incidental expenses, charge able to freight department,..................

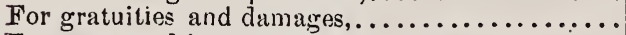

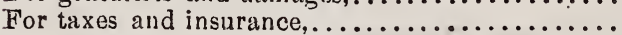

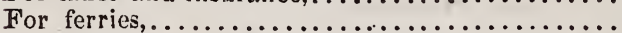

For repairs of station buildings, aqueducts, flxtures,

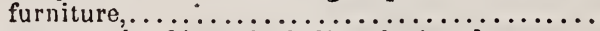

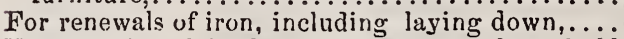

For new iron laid down, deducting value of old

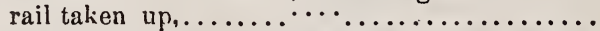

For amount paid other companies in tolla for passengers and freight carried on their roads, specify-

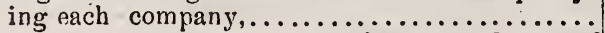

For amount paid other cumpanies as rent for use of their roads, specifying each company,.........

Fior salaries of president, treasurer, suprintendent, law expenses, office expenses of the sbove offices, and all other expenses not included in any of the foregoing items,.........................

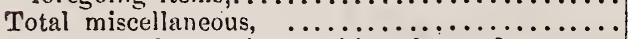

Total expenditures for working the road,.......

Total amount of interest paid during the year,....

\section{Income During Four Months.}

\section{For Passengers :-}

1. On main road including branches owned by

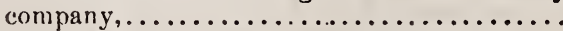
2. To and from other roads, specifying what,... For Freight:

1. On main road and branches owned by company

2. To and frem other connecting roads,........

U. S. Malls and Express, ....................

Rents and miscellaneous, ...................

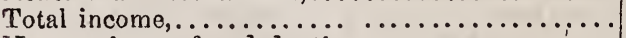

Net earnings, after deducting expenses,............

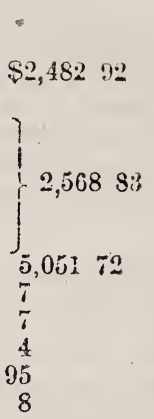

\section{.}

$\$ 2,48292$

2,568 S:

$5,051 \quad 72$

$\$ 4,21500$

29400

11,34025

$20 \quad 25$

31800

45000

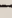

3.01700

$\$ 21,31035$

$31,163 \quad 34$

$\$ 14,54278$

$13,848 \cdot 92$

$\overline{1,667} 00$

1,50653

$\$ 31,56523$

40189 
DIVIDISNDS.

-per cent. Total

Surplus not divided

Surplus last year,

Total surplus,....

ESTIMATRD DEPRECIATION BEYOND THE RENEWALS, VIZ :-

Rond and bridges,

Building

Engines and cars

\section{Mortgage Debt5,}

A mount of debts, secured by mortgage of road and franchise, or any property of the corporation, per last report, .

Mortgage debt, paid since last report,

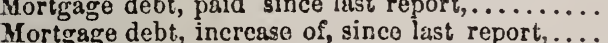

Total present amount of mortgage debt,..........

Number of mortgages on road and franchise, or

any property of the corporation,............ Three.

HENRY P. HAVEN, , Trustees of the New-London. WillimanA. (. LIPPITT, $\}$ tic and Palmer Railroad Corporation.

New-Lonnos, Cons., ss., December 23, 1861.

Then personally appeared Heury P. Haven and Andrew C. Lippitt, Trustees of the New London, Willimantic and Palmer Railroad, and severally made oath to the truth of the foregoing statement by them subscribed.

Beforc

PETER D. IRISH, Justice of the Peace. 



\section{FIFTH ANNUAL REPORT}

OF THE

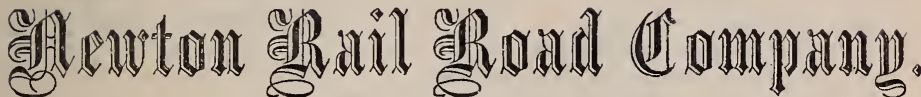

Return of the Neuton Railroad Company for the year ending November 30, 1861, under the General Statutes, Chapter 63, Sect. 143 and 144.

\section{Condition of the Company.}

Capital stock, fixed by charter _ _ _ _ Capital stock, as voted by the Company - -

Capital stock paid, in cash - - - -

Capital stock paid in, in work and materials, by contractors and others

Funded debt,

Floating debt,

Total debt,

Amount of above debt secured by mortgage of road and franchise, or any property belonging to the corporation, or standing in its name,

Number of mortgages on road and franchise, or any property of the corporation, specifying the number and amount of mortgages on road and franchise, and each kind of property,

Amount of assets on hand, exclusive of the road and equipment, and exclusive of all property on hand, used, or which is to be used, in running the road and keeping it in repair, - -

\section{Cost of the Road.}

Amounts expended for labor in excavating for the track, laying foundation and rails,

Amount expended for timber for foundation, -

Amount expended for iron and other metals for rails, chairs, spikes, or other articles, used in building the road.

Amount expended for pavin

Amount expended for paving stones,

Amount expended for engine

Amount expended for alterationg, - - ing switches, turnouts,

Amount expended for interest, salaries of officers during construction of road, and other expenses not included in any of the above items, which have been included on the books of the Company, in the cost of road, and not including items of equipment or running expenses, as mentioned below,

Total cost of road,

Amount included in the present and in past years among the ruming expenses for estimated or actual depreciation of the road,

Net cost of road,

\section{$\$ 75,00000$ \\ $28,000 \quad 00$}

$\$ 150,000 \quad 00$

None.

1,02080

The road was built by contract, embracing all labor and all materials except iron, and the stables, for $\$ 9,950$.

$\$ 9,458 \quad 54$

\} Nothing.

$\$ 1,086 \quad 43$

3,10679

$\$ 74306$

$\$ 24,34482$

None. 


\section{Cost of Equipment.}

Number of cars and cost,

Number of horses and cost

Cost of Omnibusses, sleighs, and other vehicles, excepting cars, owned by the company,

Cost of land and buildings thereon when purchased,

Cost of buildings used for offices, stables, \&c., erected by the company, or standing on land not owned by the company,

Cost of other articles of equipment, specifying what,

Total cost of equiqment,

Amount included in the present and past years in the running expenses for estimated or actual depreciation of any of the above items,

Net amount at which the equipment stands charged on the books of the company,

\section{Characteristics of the Road.}

Length of single main track,

Length of double main track, -

Total length of road, - - _ - -

Length of branches owned by the company, stating whether they have a single or double track,

Aggregate length of switches, sidings, turnouts, and other track, excepting main track and branches,

Total length of rail, $\quad$ - $\quad$ - $\quad$ - $\quad$ -

Weight of rail used, per yard, specifying whether of cast or rolled iron, - - - - -

Maximum grade, per mile, on road, with length of grade,

Shortest radius of curve, with length of curve,

Greatest length of single track on road between two turn-outs, - - - - - -

Total length of main track which is paved, -

\section{Doings during the Year.}

Total number of miles run during the year,

Number of passengers carried in the cars,

Rates of speed adopted, including stops and detensions,

Rates of speed actually attained, including stops and detensions, - $\quad-\quad$ - $\quad$ -

Number of persons employed, regularly, (specifying the occupation of each,)

Total number of trips run during the year

Average number of passengers each trip,

\section{Expenditures for working the Road.}

For repairs of road, including repairs of foundation, renewals of iron, and renewals of pavement,

For general repairs, including repairs of cars, omnibusses and harnesses, and for shoeing horses,

For repairs of real estate, including repairs of buildings used as stables, offices, or for any other purposes, by the Company,
The road is leased, the lessees equiping and operating it.

\section{$\$ 800 \quad 00$}

\$\$\$ 1,70000

Nothing.

$\$ 2,50000$

Nothing.

2 7-8 miles.

No double track.

2 7-8 miles.

None.

55 rods.

3 miles.

33 lbs., rolled iron.

264 feet for 100 feet long. 150 feet.

1 1-6 mile.

None.

51,858

223,228

8 miles per hour.

8 miles per hour.

3 drivers, 5 conductors. 8643

$258-10$

Nothing. 
For wages, including the wages of every person:; regularly employed, excepting the president, directors, superintendent and treasurer,

For interest,

For taxes and insurance, $\quad-\quad-\quad-\quad-$

For tolls paid other companies for the right to pass over their roads,

For rent paid other companies for use of their roads,

For provender, (to include cost of hay, grain, straw, or other articles used for the food and bedding of horses,

For miscellaneous articles purchased during the year, (such as harnesses, blankets, \&c., the use of which continues for one or more years,) and not included in the cost of equipment,

For loss on horses, (that is to say, the difference between the present estimated value of the horses owned by the Company, subtracted from the estimated value of those on hand at the commencement of the year, added to the cost of those purchased during the year; or if this is the first report of the Company, then the difference bctween the estimated value of the horses on hand and their cost,) giving the present average estimated value of each horse,

For incidental expenses, to include printing, president's, directors', treasurer's and superintendent's salaries, and all expenses other than those belonging to the actual working of the road, For all other expenses,

For amount charged on the Company's books during the year, for estimated or actual depreciation of the following property:-

Cars,

Horses,

Omnibusses,

Real Estate

Road,

Other property,

Total expenses, Total, -

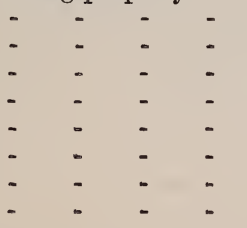

Nothing.

Nothing.

$\$ 2100$

$\$ 8954$

Earnings.

Received from passengers in cars and omnibuses, and for tickets sold,

From lessees, as toll or rent for use of road,

From United States Mails,

For sales of manure,

From other sources,

Total earnings,

Net earnings after deducting expenses,

Surplus earnings of previous year, on hand,

Net earnings, as above.

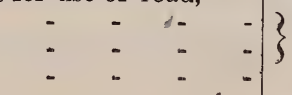

Nothing.

$\$ 177800$

Total surplus for payment of dividends, -

Dividends declared during the year, ( 2 of )

Total percentage of dividends for the year,

Present surplus,

Nothing.

$\$ 3000$

$\$ 180800$

$\$ 169746$

$\$ 1252$

$\$ 169746$

$\$ 170998$

- 3 per cent.

6 per cent.

$\$ 2998$ 


\section{Miscellaneous.}

Increase during the year:-

Of capital stock, as fixed by the charter, - None.

Of capital stock, as voted by the Company, - None.

Of capital stock, paid in, - $\quad$ - $\quad$ - $\quad$ - $\$ 20000$

Increase of funded debt, during the year, - )

Increase of floating debt, during the year, -

Decrease of funded debt, during the year, -

Decrease of floating debt, during the year, -

Increase of mortgage debt, during the year, -

Decrease of mortgaged debt, during the year, -

Increase in cost of road, during the year, including amount charged for depreciation thereon,

Decrease in nominal cost of the road, amount charged for depreciation thereon,

Increase in cost of equipment during the year, including amount charged for depreciation thereon,

Decrease in cost of equipment, by sale of any portion thereof, or by amount charged for depreciation,

List of accidents on the road during the year,

None.

W. C. STRONG,

GRANVILLE FULLER,

ISAAC PRATT, JR.,

J. F. TAYLOR,

A majority of the Directors of the Newton Railroad Company.

MIDDLESEX, SS. Dec. 18th, 1861. Then personally appeared W. C. Strong, Granville Fuller and Isaac Pratt, Jr., and severally made oath to the truth of the foregoing statement by them subscribed, according to their best knowledge and belief.

Before GEORGE B. BIGELOW, Justice of the Peace.

MIDDLESEX, SS. Dec. 25th, 1861. Then personally appeared Jacob F. Taylor, and made oath that the foregoing statement by him subscribed is true, according to his best knowledge and belief.

Before

GEORGE B. BIGELOW, Justice of the Peace. 


\section{R E P O R T}

OF THE TRUSTEES OF THE BONDHOLDERS OF THE

\section{Norfolk County RaIlroad CoRporation,}

For the Year Ending November 30, 1861.

Capital stock,

Number of shares of capital stock issued,

Increase of capital since last Report, - -

Capital paid in, per last Report, -

Capital paid in, since last Report, -

Total amount of capital stock paid in, -

Funded debt, per last Report,

Funded debt paid since last Report, - .

Funded debt, increase of, since last Keport, -

Total present amount of funded debt, -

Floating debt, per last Report, - -

Floating debt, paid since last Report, - -

Total present amount of floating debt, -

Average rate of interest per annum, paid during the year,

Maximum amount of debts during the year, -

\section{Cost of Road and Equipment.}

For graduation and Masonry, per last Report, -

For graduation and masonry, paid during the past year,

Total amount expended for graduation and masonry,

For wooden bridges, per last Report, -

For wooden bridges, paid during the past year,
Total amount expended for wooden bridges,

Total amount expended for iron bridges, (if any),

For superstructure, including iron, per last Report,

For superstructure including iron, paid during the past

Total amount expended for superstructurc, including iron,

For stations, buildings and fixtures, per last Report,

For stations, buildings and fixtures, paid during the past year,

Total amount expended for stations, buildings and fixtures,

For land, land-damages and fences, per last Report,

For land, land-damages and fences, paid during the past year,

Total amount expended for land, land-damages and fences,

For locomotives, per last Report, - $\quad$ -

For locomotives, paid during the past year, -
Total amount expended for locomotives, -

For passenger and baggage cars, per last Report,

For passenger and baggage cars, paid during the past

Total amount expended for passenger and baggage

For merchandise cars per last Report, - 
For merchandise cars, paid during the past year,

Total amount expended for merchandise cars,

For engineering, per last Report,

For engineering, paid during the past year, -

Total amount expended for engineering, -

For agencies and other expenses, per last Report,

For agencies and other expenses, paid during the past year,

Total amount expended for angencies and other expenses,

Total cost of road and equipment, -

Amount of assets or property held by the corporation in addition to the cost of the road,

Characteristics of Road.

Length of road,

Length of single main track, - - -

Length of double main track, - - -

Length of branches owned by the company, stating whether they have a single or double track,

Aggregate length of sidings, and other tracks, excepting main track and branches,

Weight of rail per yard, in main road, -

Weight of rail per yard, in branch roads, (specify the different weights per yard),

Maximum grade, with its length, in main road,

Maximum grade, with its length, in branch roads,

Total rise and fall in main road,

Total rise and fall in branch roads,

Shortest radius of curvature, with length of curve, in main road,

Shortest radius of curvature, with length of curve, in branch roads,

Total degrees of curvature in main road,

Total degrees of curvature in branch roads,

Total length of straight line in main road,

Total length of straight line in branches,

Aggregate length of wooden truss bridges,

Aggregate length of all other wooden bridges,

Aggregate length of iron bridges,

Whole length of road unfenced on both sides,

Number of public ways crossed at grade,

Number of railroads crossed at grade,

Remarks,

Way stations for express trains, a

Way stations for accommodation trains,

Flag stations,

Whole number of way stations,

Whole number of flag stations,

Miles run by passenger trains, - -

Miles run by freight trains, -

Miles run by other trains, -

Total miles run, - - - -

Number of passengers carried in the cars, -

Number of passengers carried one mile,

Number of tons of merchandise carried in the cars,

Number of tons of merchandise carried one mile,

Number of passengers carried one mile, to and from other roads,

Number of tons carried one mile, to and from other roads,

Rate of speed adopted for express passenger trains, including stops,

Average rate of speed actually attained by express passenger trains, including stops and detentions,
These questions are not

answered because the

. Trustees have not the

facts in their posses-

sion to answer them.

26 miles.
Nineteen.

None.

Five.

Six.

Eight.

Twelve.

Eight.

28,928

16,224

630

81,926

$1,027,512$

17,220

302,428

805,372

235,020

24 miles per hour.

24 66
45,782 
Rate of speed adopted for accommodation trains,

Rate of speed actually attained by accommodation trains, including stops and detentions, - -

Average rate of speed actually attained by special trains, including stops and detentions,

Average rate of speed adopted for freight trains, including stops,

Estimated weight in tons, of passenger cars, (not including passengers), hauled one mile,

Estimated weight in tons, of merchandise cars, (not including freight), hauled one mile,

Expenditures for Working the Road.

For repairs of road, maintenance of way, exclusive of wooden bridges, and renewals of iron, -

For repairs of wooden bridges,

For wages of switchmen, average per month, $\$$

For wages of gate-keepers, average per month, $\$$

For wages of signal-men, average per month, $\$$

Far wages of watchmen, average per month, \$

Number of men employed exclusive of those engaged in construction,

-

For removing ice and snow, (this item to include all labor, tools, repairs, and extra steam power used),

For repairs of fences, gates, houses for signal men, gatekeepers, switchmen, tool houses,

Total for maintenance of way, - -

Motive Power and Cars.

For repairs of locomotives, - -

For repairs of passenger cars, -

For new passenger cars, to cover depreciation,

For repairs of merchandise cars,

For new merchandise cars to cover depreciation,

For repairs of gravel and other cars,

Total for maintenance of motive power and cars,

Number of engines,

Number of passenger cars, -

Number of baggage cars, -

Number of merchandise cars, -

Number of gravel cars, -

\section{Miscellaneous.}

For fuel used by engines during the year, viz :

Wood, number of cords, 105. Cost of the same,

Coal, number of tons, (reckoning 2,240 lbs. to the ton,) 720. Cost of same,

For oil used for cars and engines,

For waste and other materials used for cleaning,

For salaries, wages, and incidental expenses, chargeable

to passenger department,
For salaries, wages, and incidental expenses, chargeable to freight department,

For gratuities and damages,

For taxes and insurance,

For ferries,

For repairs of station buildings, aqueducts, fixtures, furniture,

For renewals of iron, including laying down, -

For new iron laid down, deducting the value of old iron taken up,

For amount paid other companies, in tolls for passengers and freight carried on their roads, specifying each company,
18 miles per hour.

18 “ “
16 “
9

$1,220,320$

868,804

$10,600.63$

424.65

696.00

49

266.57

25.00

$12,012.85$

$2,853.88$

370.67

$2,913.68$

Three.

$6,138.23$

Six.

Two.

Fifty-six.

Ten.

423.25

$4,276.99$

606.61

70.66

$4,303.78$

$3,878.74$

67.28

68.74

105.20

562.50

$7,866.33$ 
For amount paid other companies, as rent for use of their roads, specifying each company, -

For salaries of president, treasurer, superintendent, law expenses, office expenses of the above offices, and all other expenses, not included in any of the foregoing items,

Total miscellaneous, - - -

Total expenditures for working the road, -

Total amount of interest paid during the year,

INCOME DURING THE YEAR.

\section{For Passengers :}

1. On main road, including branches owned by com-

2. To and from other roads, specifying what,

For Freight :

1. On main road and branches owned by company,

2. To and from other connecting roads,

U. S. Mails,

\section{Rents,}

Total income,

Net earnings, after deducting expenses,

\section{Dividends.}

11 per cent. Total, Surplus not divided, Surplus last year,

Total surplus,

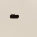

-

$-$

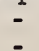

$-$

$-$

$-$

$-$

$-$

$-$
$5,540.11$

$27,770.19$

$45,921.27$

$30,774.99$

$19,022.94$

$2,090.75$

$3,115.00$

$55,003.68$

$9,082.41$

$46,821.22$

$20,389.25$

$58,128.06$

Estimated Depreciation Beyond the Renewals, viz: Of Road and Bridges, Buildings, Engines and cars,

\section{Mortgage Debts.}

Amount of debts secured by mortgage of road and franchise, or any property of the corporation, per last Report,

Mortgage debt paid since last Report, -

Increase of mortgage debt since last Report, -

Present amount of mortgage debts,

Number of mortgages on road and franchise, or any property of the corporation,

\section{ISAAC DAVIS,} J. W. CONVERSE,

Trustees of the Bondholders WELCOME FARNUM, $\} \begin{aligned} & \text { of the Norlroad Corporation. } \\ & \text { Railk County }\end{aligned}$

Sufrolk, ss., December 20th, 1861.

Then personally appeared J. W. Converse and Welcome Farnum, and severally made oath to the truth of the foregoing statement by them subscribed.

Before

PAUL, P. TODD, Justice of the Peace.

Worcester, ss., December 21, 1861.

Then personally appeared Isaac Davis, and made oath to the truth of the foregoing statement by him subscribed.

Before me,

CALEB DANA, Justice of the Peace. 


\section{TWENTY-SIX'TH ANNUAL REPOR'T}

OF THE

\section{NoRWICH \& Worcester RaILROAD COMPaNy.}

To the Honorable the Legislature of the Commonwealth of Massachusetts : The Directors of the Norwich \& Worcester Railroad Company respectfully submit their return and report of their doings during the year ending November 30th, 1861, as required by law.

Capital stock, - - - - -

Number of shares of capital stock issued, -

Increase of capital since last Report, -

Capital paid in, per last Report, -

Capital paid in, since last Report, -

Total amount of capital stock paid in, -

Funded [and deferred] debt, per last Report, -

Funded debt paid since last Report,

Funded debt, increase of, since last Report, -

Total present amount of funded [and deferred] debt,

Floating debt, per last Report,

Floating debt, paid since last Report, -

Floating debt, increase of, since last Report, -

Total present amourit of floating debt, -

Total present amount of funded, [deferred] and floating debt,

Average rate of interest per annum, paid during the year,

Maximum amount of debts during the year, -

Cost of Road and Equipment.

For graduation and masonry, per last Report, -

For graduation and masonry, paid during the past year,

Total amount expended for graduation and masonry,

For wooden bridges, per last Report,

For wooden bridges, paid during the past year,

Total amount expended for wooden bridges.

Total amount expended for iron bridges, (if $\varepsilon n y$ ),

For superstructure, including iron, per last Report,

For superstructure including iron, paid during the past year,

Total amount expended for superstructurc, including iron,

For stations, buildings and fixtures, per last Report,

For stations, buildings and fixtures; paid during the past year,

Total amount expended for stations, buildings and fixtures,

For land, land-damages and fences, per last Report,

For land, land-damages and fences, paid during the past year,

Total amount expended for land, land-damages and fences,

For locomotives, per last Report

For locomotives, paid during th

Total amount expended for locomotives, -
21,255

$\$ 2,825,000.00$

$2,122,500.00$

$630,600.00$

$2,122,500.00$

$178,700.00$

$25,986.02$

$36,491.19$

$62,477.21$

$871,777.21$

Six and one-half of one per cent.

$936,738.11$

$\$ 614,529.92$

$32,750.59$

$614,529.92$

$32,750.59$

$357,181.48$

$357,181.48$

$49,168.93$

$142,591.71$

$49,168.93$

$75,540.44$ 
For passenger and baggage cars, per last Report,

For passenger and baggage cars, paid during the past year, year,
Total amount expended for passenger and baggage cars,

For merchandise cars per last Report, - -

For merchandise cars, paid during the past year,

Total amount expended for merchandise cars,

For engineering, per last Report,

For engineering, paid during the past year, -

Total amount expended for engineering, -

For agencies and other expenses, per last Report,

For agencies and other expenses, paid during the past year,

Total amount expended for agencies and other ex-

penses,
Total cost of road and equipment, -

Amount of assets or property held by the corporation in addition to the cost of the road,

\section{Characteristics of Road.}

Length of road,

Length of single main track, -

Length of double main track,

Length of branches owned by the company, stating whether they have a single or double track,

Aggregate length of sidings, and other tracks, excepting main tracks and branches,

Weight of rail per yard, in main road, -

Weight of rail per yard, in branch roads, (specify the different weights per yard),

Maximum grade, with its length, in main road,

Maximum grade, with its length, in branch roads,

Total rise and fall in main road,

Total rise and fall in branch roads,

Shortest radius of curvature, with length of curve, in main road,

Shortest radius of curvature, with length of curve, in branch roads,

Total degrees of curvature in main road,

Total degrees of curvature in branch roads,

Total length of straight line in main road, -

Total length of straight line in branches, -

Aggregate length of wooden truss bridges, -

Aggregate length of all other wooden bridges, -

Aggregate length of iron bridges,

Whole length of road unfenced on both sides,

Number of public ways crossed at grade,

Number of railroads crossed at grade, -

Remarks,

Way stations for express trains, - -

Way stations for accommodation trains,

Flag stations, - - - -

Whole number of way stations,

Whole number of flag stations,

\section{Doings during the Year.}

Miles run by passenger trains,

Miles run by freight trains,

[Miles run by express freight trains,] -

Miles run by other trains,

Total miles run,

Number of passengers carried in the cars,
$\$ 31,524.88$

$31,524.88$

$42,646.25$

$42,646.25$

$69,499.50 \frac{1}{2}$

$69,499.50 \frac{1}{2}$

$1,198.260 .50 \frac{1}{2}$

$2,613,694.21$

$388,935.65$

59 4-10 miles.

59 4-10 miles.

1 8-10 miles.

7 miles-single.

6 7-10 miles.

56 and $60 \mathrm{lbs}$.

56 and $60 \mathrm{lbs}$.

32 feet for 13,265 feet.

815.74

1,910 feet for 3,639 feet \} in Massachusetts.

$424^{\circ} 30^{\prime}$ in Mass.

12 8-10 miles in Mass.

1309 feet.

74

\{ 2 - Western, and Prov.

Hartford \& Fishkill.

3

14

4

17

4

149,498 miles.

79,573 "

41,204 “

4,273

149,960 
Number of passengers carried one mile,

Number of tons of merchandise carried in the cars,

Number of tons of merchandise carried one mile,

Number of passengers carried one mile, to and from other roads,

Number of tons carried one mile, to and from other roads,

Rate of speed adopted for exlress passenger trains, including stops,

Average rate of speed actually attained by express passenger trains, including stops and detentions,

Rate of speed adopted for accommodation trains,

Rate of speed actually attained by accommodation trains,

including stops and detentions, -
Average rate of speed actually attained by special trains,

including stops and detentions, -
Average rate of speed adopted for freight trains, including stops,

Estimated weight in tons, of passenger cars, (not including passengers), hauled one mile,

Estimated weight in tons, of merchandise cars, (not including freight), hauled one mile,

\section{Expenditures for Working the Road.}

For repairs of road, maintenance of way, exclusive of wooden bridges, and renewals of iron, -

For repairs of wooden bridges,

For wages of switchmen, average per month, $\$ 28$,

For wages of gate-keepers, average per month, $\$ 36$, ङ For wages of signal-men, average per month, $\$ 13$, Far wages of watchmen, average per month, $\$ 33$,

Number of men employed exclusive of those engaged in construction,

For removing ice and snow, (this item to include all labor, tools, repairs, and extra steam power used),

For repairs of fences, gates, houses for signal men, gatekeepers, switchmen, tool houses,

Total for maintenance of way, -

\section{Motive Power and Cars.}

For repairs of locomotives, - - -

For new locomotives to cover depreciation, -

For repairs of passenger cars, - -
For new passenger cars, to cover depreciation,

For repairs of merchandise cars, - . -

For new merchandise cars to cover depreciation,

For repairs of gravel and other cars, - -

Total for inaintenance of motive power and cars,

Number of engines,

Number of passenger cars;

Number of baggage cars,

Number of merchandise cars,

Number of gravel cars,

\section{Miscellaneous.}

For fuel used by engines during the year, viz :

Wood, number of cords, Cost of the same, Coal, number of tons, (reckoning 2,240 lbs. to the ton,)

Cost of same,

For oil used by cars and engines,

For waste and other material for cleaning,

For salaries, wages, and incidental expenses, chargeable to passenger department,

For salaries, wages, and incidental expenses, chargeable to freight department,
$3,124,757$
95,530
$5,036,955$

$1,077,840$

30 miles per hour.

30 miles per hour.

20 " "

20 miles per hour.

22 miles per hour.

$7 \frac{1}{2}$ miles per hour.

$5,000,000$

$12,000,000$

$\$ 28,023.55$

556.44

$5,174.01$

206 men.

$2,155.66$

29.89

$35,939.55$

$\$ 12,977.49$

$2,652.12$

$4,965.00$

$7,667.71$

$13,850.21$

$1,389.34$

Fourteen.

$43,501.87$

Eighteen.

Two.

Three hundred and eight.

Five.

$\$ 25,567.69$

$2,321.43$

$3,542.07$

507.77

$16,260.48$

$29,654.78$ 
For gratuities and damages, -
For taxes and insurance,
For ferries,
For repairs of station buildings, aqueducts, fixtures,
furniture,
For renewals of iron, including laying down, -
For new iron laid down, deducting the value of old iron
taken up, -
For amount paid other companies, in tolls for passen-
gers and freight carried on their roads, specifying
each company. -
For amount paid other companies, as rent for use of
their roads, specifying each company, -

For salaries of president, treasurer, superintendent, law expenses, office expenses of the above offices, and all other expenses, not included in any of the foregoing items,

Total miscellaneous,

Total expenditures for workin

Total amount of interest paid during the year,

[Total expenses and interest,] -

\section{INCOME DURING THE YeAR.}

For Passengers :

1. On main road, including branches owned by company,

2. To and from other roads, specifying what, [Boston \& Worcester; Worcester \& Nashua ; Providence, Hartford \& Fishkill ; New London \& Northern Railroads, ]

For Freight :

1. On main road and branches owned by company,

2. To and from other connecting roads, [Boston \& Worcester; Worcester \& Nashua; Providence, Hartford \& Fishkill; New London \& Northern Railroads, ]

U. S. Mails,

Rents, $[\$ 1,043.66$; other income, $\$ 5,736.93$,

Total income,

Net earnings, after deducting expenses [and interest],

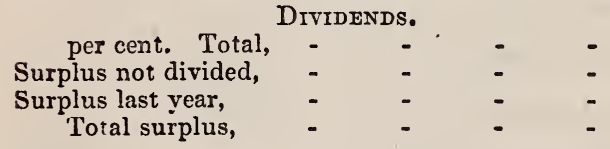

Estimated Depreciation Beyond the Renewals, viz: Of Road and Bridges,

Buildings,

Engines and cars,

\section{Mortgage Debts.}

Amount of debts secured by mortgage of road and franchise, or any property of the corporation, per last Report,

Mortgage debt paid since last Report,

Increase of mortgage debt since last Report, -

-Present amount of mortgage debts, -

Number of mortgages on road and franchise, or any property of the corporation,
955.82

$1,684.01$

$3,418.72$

129.64

$16,402.88$

$179,886.71$

$40,712.14$

$100,445.29$

$220,598.85$

$\$ 66,516.89$

$42,382.71$

$108,899.60$

$121,850.64$

$44,193.90$

$166,044.54$

$6,787.49$

$6,780.59$

$13,568.08$

$288,512.22$

$67,913.37$
$\$ 630,600.00$

$178,700.00$

$809,300.00$

Five. 
March 8th, 1861. Dwight Ray, while intoxicated on the Railroad track, about two miles North of Jewett City, was run over by express freight train and killed.

All of which is respectfully submitted, with the Report of the Commissioners of the Commonwealth of Massachusetts and State of Connecticut, as required by law.

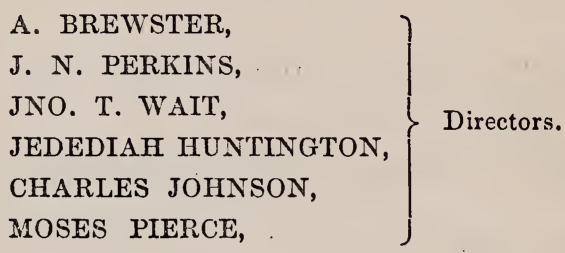

\section{State of Connecticut, ? County of New London, ss. $\}$}

Personally appeared before me, on the 26th day of December, A. D. 1861, the above-named A. Brewster, J. N. Perkins, Jno. T. Wait, Jedediah Huntington, Charles Johnson, and Moses Pierce, and made solemn oath that the within accounts by them subseribed were true, according to their best knowledge and belief.

LEVI H. GODDARD,

Justice of the Peace. 
TWENTY-SIXTH ANNUAL REPORT OF THE COMMISSIONERS OF THE STATES OF MASSACHUSETTS AND CONNECTICUT.

The undersigned, having been called upon to examine the accounts of the Norwich \& Worcester Rail Road Company relative to the Expenditures of the Road and to decide what portion of said expenditures are to be applied to the different sections of the road, report that on the 25 th day of December, A. D. 1861, we examined the accounts of said Company to the 30 th November, 1861, and found that there had been expended for the Road in Connecticut to the 30th of November, 1861, the sum of

$\$ 1,840,597.60$

That there had been expended in Massachusetts to the 30th of

November, 1861, the sum of

$773,096.61$

Making the whole cost of the Road to the 30 th of November, 1861,

$2,613,694.21$

They further report that the accounts of the Expenditures on the Road in each State have been kept scparate and distinct, as required by the Charter; that the Receipts of the Company for twelve months ending November 30 th, 1861, were

$\$ 288,512.22$

Expenditures were for Repairs of Road, Cars, Locornotives, new

Locomotives, Bridges, Station Houses, Fuel, Passenger and

Freight Expenses, \&c., \&c.

$179,886.71$

$108,625.51$

From which deduct interest,

$40,712.14$

Leaving Net, after paying expenses and interest,

$67,913.37$

Of which we have set down to Massachusetts, one-third,

$22,637.79$

And to Connecticut, two-thirds,

$45,275.58$

$67,913.37$

All of which is respectfully submitted.

CHARLES I. PUTNAM,

Commissioner for Massachusetts.

THOMAS ROBINSON,

Commissioner for Connecticut. 




\title{
EIGHTH ANNUAL REPORT
}

OF THE

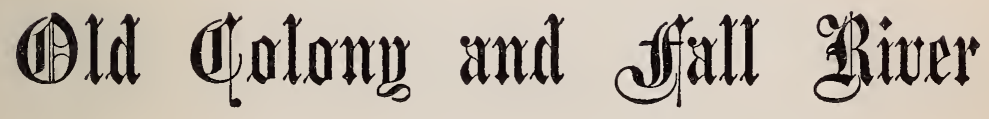

\author{
RAILROAD COMPANY.
}





\title{
RETURN OF THE OLD COLONY AND FALL RIVER RAILRI)AD COMPANY,
}

\author{
FOR THE YEAR ENDING NOVEMBER 30, 1861.
}

Required by Acts of 1849 , Chap. 191 ; 1851, Chap. 102 ; 1854, Chap. 423; 1856, Chap. 165 ; 1857, Clapters 40, 168 and 240 ; and 1858, Chap. 46.

Capital stock, [authorized by charters,] Number of shares of capital stock issued, Increase of capital, since last report, . Capital paid in, per last report, . Capital paid in, since last report, ${ }^{2}$. Total amount of capital stock paid in, . Funded debt, per last report, . Funded debt, paid since last report, . Funded debt, increase of, since last report, Total present amount of funded debt, . Floating debt, per last report,

Floating debt, paid since last report, . Floating debt, increase of, since last report, Total present amount of floating debt, Total present amount of funded and floating debt, Average rate of interest per annum, paid during the year, Maximum amount of debts during the year,

\section{Cost of Road and Equipment.}

For cost of Abington Branch, per last report,

For graduation and masonry, per last report,

For graduation and masonry, paid during the past year,

Total am't expended for graduation and masonry,

For wooden bridges, per last report,

For wooden bridges, paid during the past year,

Total amount expended for wooden bridges,

Total amount expended for iron bridges (if any,)

For superstructure, including iron, per last report,

For superstructure, including iron, paid during the past year,

Total amount expended for superstructure, including iron,

For stations, buildings and fixtures, per last report,

For stations, buildings and fixtures, paid during the past year, (\$2,779 86 charged in expenses,)

Total amount expended for stations buildings and fixtures, excepting am't charged in expenses,

For land, land-damages and fences, per last report,

For land, land-damages and fences, paid during the past year,

Total amount expended for land, land-damages and fences, excepting am't charged in exp's,

$$
\begin{array}{cccc}
30,151 & \$ 3,300,000 & 00 \\
\$ 3,015,100 & 00 & - & \\
- & & - & \\
107,000 & 00 & 3,015,100 & 00 \\
26,000 & 00 & & \\
- & & - & \\
76,500 & 00 & & \\
- & & - & \\
45,278 & 00 & & \\
& & 121,778 & 00 \\
& & 202,778 & 00
\end{array}
$$

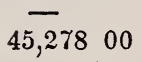

Nearly six per cent.

$245,278 \quad 00$

$129,098 \quad 87$

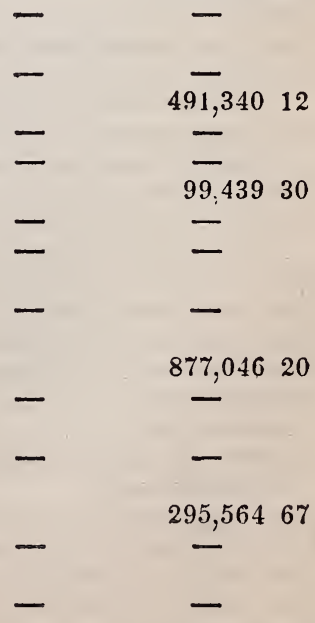

851,05132 
For locomotives, per last report, .

For locomotives, paid during the past year,

Total amount expended for locomotives,

For passenger and baggage cars, per last report,

For passenger and baggage cars, paid during the past year, (\$1,900 00) charged in expenses, )

Total amount expended for passenger and baggage cars, excepting arn't charged in expenses,

For merchandise cars, per last report,

For merchandise cars, pard during the past year, (new cars built at shop, charged in expenses: 8 long flat and box ca s, 33 giavel cars.)

Total amount expended for merchandise cars,

For engineering, per last report,

For engineering, paid during past year, .

Total amount expended for engineering,

For agencies and other expenses, per last report,

For agencies and other expenses, paid during the past year,

Total amount expended for agencies and other expenses,

Total cost of road and equipment,

Less charged off for deterioration,

Amount of assets or property held by the corporation in addition to the cost of the road, (the surplus earnings after deducting the dividend to be paid in January,).

\section{Characteristics of Road.}

Length of road,

Length of single main track,

Length of double main track,

Length of branches owned by the company, stating whether they have a single or double track,

Aggiegate length of sidings, and other tracks, excepting main tracks and branches, .

Weight of rail, per yard, in main road,

Weight of rail, per yard, in branch roads, (specify the different weights per yard,)

Maximum grade, with its length in main road,

Maximum grade, with its length in branch roads.

Total rise and fall in main road, .

Total rise and fall in branch roads,

Shortest radius of curvature, with length of curve in main road,

Shortest radius of curvature, with length of curve in branch roads,

Total degrees of curvature in main road,

Total degrees of curvature in branch roads,

Total length of straight line in main road,

Total length of straight line in branches,

Aggregate length of wooden truss bridges,

Aggregate length of all other wooden bridges,

Aggregate length of iron bridges,

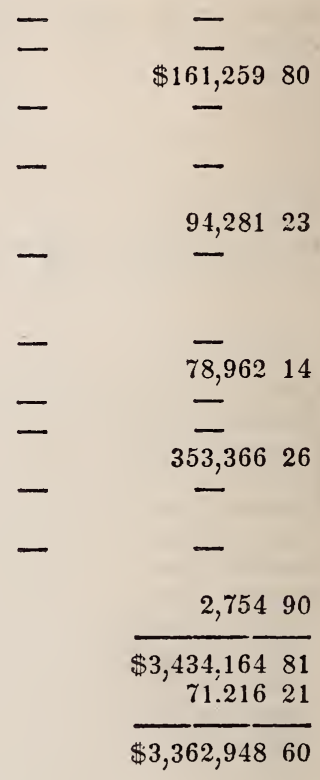

$\$ 729,526 \quad 69$

79 1-2 miles.

79 1-2 miles.

11 1-2 miles.

7 3-4 miles, single track.

15 miles.

54 to $60 \mathrm{lbs}$.

50 to 56 lbs.

44 85-100 for 400 feet.

39 $6-10$ for 875 feet.

1,383 feet.

148 feet.

520 feet for 450 feet.

301 feet for 140 feet.

$1,538^{\circ}$.

$178^{\circ}$.

60 miles 2,550 feet.

5 miles 4,708 feet.

284 feet.

1.500 feet.

None. 
Whole length of road unfenced on both sides; .

Number of public ways crossed at grade,

Number of railroads crossed at grade, .

Remarks, .

Way stations for express trains,

Way stations for accommodation trains,

Flag stations,

Whole number of way stations, :

Whole number of flag stations, .

\section{DoINgS DURING the Year.}

Miles run by passenger trains,

Miles run by freight trains,

Miles run by other trains,

Total miles run,

Number of passengers carried in the cars,

Number of passengers cariied one mile, .

Number of tons of merchandise carried in the cars,

Number of tons of merchandise carried one mile,

Number of passengers carried one mile, to and from oiher roads,

Number of tons carried one mile, to and from other roads,

Rate of speed adopted for express passenger trains, including stops,

Average rate of speed actually attained by express passenger trains, inclu.ling stops and deteutious,

Rate of speed adopted for accommodation trains,

Rate of speed actually attained by arcommodation trains, iurluding stops and delentions, .

Average rate of speed actually attained by special trairis, iucluding stops and detentions, .

Average rate of speed adopted for freight trains,

iucluding stops,
Estimated weight in tons of passenger cars, (not including pas-engers), hauled one mile, (not includiug freight), hauled une mile,

\section{Expenditures for Working the Road.}

For repairs of road, maintenance of way, exclusive of wooden bridges, and renewals of iron,

For repairs of wooden bridges,

For wagres of switchmen, average per month, $\$ 30$

For wayes of gate-keepers, average permonth, $\$ 33$

For wages of signal-men, average per month, \$25

For wages of watchmen, average per month, $\$ 33$

Number of men employed, exclusive of those engaged in construction,

For removing ice and snow, (this item to include all labor, tools, repairs, and extra steam-power used,)

For repairs of fences, gates, houses for signalmen, gate-keepers, switchmen, tool-houses,

Total for maintenance of way: .

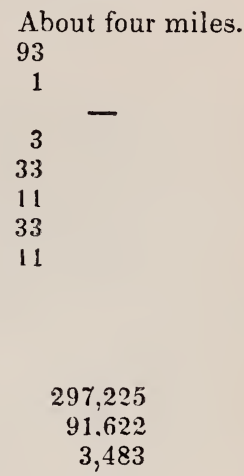

About four miles. 93

1

3

33

11

33

11

297,225

91.622

3,483

957373

$13,280,415$

142,242

$4,885,063$

$5,834,424$

$1,141,809$

33 miles per hour.

33 miles per hour. 23 miles per hour.

23 miles per hour.

20 miles per hour.

12 miles per hour.

$11,200,000$

$3,216,000$

392,330

$\$ 42,80278$

5.02371

3,22400

$1,193+1$

$2,842 \quad 16$

3,30202

320 


\section{Motive Power and Cars.}

For repairs of locomotives,

For new locomotives, to cover depreciation,

For repairs of passenger cars,

For new passenger cars, to cover depreciation,

For repairs of merchandise cars, .

For new merchandise cars, to cover depreciation, [40 new cars built at shop.]

For repairs of gravel and other cars,

Total for maintenance of motive power and cars,

Number of engines,

Number of passenger cars,

Number of baggace cars, .

Number of merchandise cars

Number of gravel cars,

\section{Miscejdaneous.}

For fuel used by engines during the year, viz:

Wood, number of cords, $\longrightarrow$ Cost of the same,

Coal, number of tons, (reckoning $2,240 \mathrm{lbs}$. to the ton, ) Cost of the same,

For oil used by cars and engines

For waste and other material for eleaning,

For salaries, wages and incidental expenses, chargeable to passenger department, .

For salaries, wages and incidental' expenses, chargeable to freight department,

For gratuities and damages,

For taxes and insurance, .

For ferries, .

For repairs of station buildings, aqueducts, fixtures, furniture, .

For station buildings,

For renewals of iron, including laying down,

For new iron laid down, deducting the value of old iron taken up, $(\$ 25,91547$,

For amount paid other companies, in tolls for passengers and freight carried on their roads, specifying each company,

For amount paid other companies, as rent for use of their roads, specifying each company,

For salaries of president, treasurer, law expenses, office expenses of the above offices, and all other expenses not included in any of the foregoing items, .

For U. S. Mails,

Total Miscellaneous,

Total expenditures for working the road,

Total amount of interest paid during the year, on Bonded debt and Bills payable,
$\$ 19,53650$

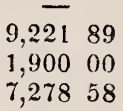

$4,81 \overline{7} 02$

27

49

15

412

included in the above.

$\$ 6,430 \quad 23$

25,28581

$6,077 \quad 77$

88183

43,36451

31,24471

$16,490 \quad 00$

7,88280

3,63903

$2,779 \quad 86$

$25,915 \quad 47$

$10.122 \quad 00$

1,30500
$42,753 \quad 99$ 
INCOME DURING THE YEAR.

For Passengers :- $\$ 326,986$ 50-say,

1. On main road, including brauches owned by company,

2. To and from other roads, specifying what :Cape Cod and Fairhaven Branch, South Shore, Taunton and New Bedford, Middleboro' and Taunton, Doichester and Milton Branch,

For Freight:-\$151,073 77,-say,

1. On main road and branches own-u by company,

2. To and from other connectir roads:-Cape Cod and Fairhaven Broch, South Shore, Taunton and New Bosilord, Middleboro' and Taunton, Dorcheoter and Milton Branch,

\section{U. S. Mails,}

Rents,
Running Dorchester and Milton trains,

Totạli income,

Net earnings, after deducting expenses, .

\section{DIVIDENDS.}

6 per cent. Total,

Surplus not divided,

Surplus last year, .

Total surplus,

Estimated Depreciation beyond the ReNEWALS, VIZ.:

Of road and bridges,

Buildings, .

Engines and cars, .

\section{Mortgage Debts.}

Amount of debts, secured by mortgage of road and franchise, or any property of the Corporation, per last report,

Mortgage debt, paid since last report,

Increase of mortgage debt since last report,

Present amount of mortgage debts,
Number of mortgages on road and franchise, or any property of the corporation,
$\$ 268,630 \quad 17$

$\sim, 35633$

$128,564 \quad 69$

22,50908

$10,750 \quad 00$

$13,321 \quad 10$

3,18940

505,32077

208,73547

180,90600

$27,829 \quad 47$

701,69722 


\section{ACCIDENTS.}

$A_{y}, r i l, 1861$-J. F. McClair, of Quincy, unlawfully walking upon the track, fell agains st the engine when passing him, and was fatally injured.

April. Mr. "Snell, of Bridgewater, unlawfully walking upon the track, was hit by an engine, w? nat fally injured.

Sept. 3. Emma F. C. Thater, a child, while playing upon the track in the yard of the Boston Depot, was hit $t^{-4}$ by a train and her arm badly crushed.

Sept. 12.-Patrick Sullivan, a wrakeman on a freight train, fell from the cars, the train passing over fatally injuring thim.

Oct. 3.-M. W. Dwight jumped from a car ii near Campello Station, and was killed,-the train was at full speed.

Oct. 3.-Timothy Sullivan, of Braintree, had his tó 't badly crushed at Harrison Square.

Oct. 28.-Mrs. O'Neil, of Quincy, run against a train, and was ilis-tantly killed.

ALEXANDER HOLME:S,

JAMES H. BEAL,

C. C. GILBERT.

F. B. CROWNINSHIELD,

GEORGE A. KETTELL.

\section{Commonwealth of Massachusetts.}

Plymouth, ss. December 28, 1861. Then personally appeared Alexander Holmes, James H. Beal, and C. C. Gilbert, and severally made oath to the truth of the foregoing statement, by them subscribed.

\section{Before Joseph S. BeaL, Justice of the Peace.}

Suffole, ss. December 30,1861. Then personally appeared F. B. Crowninshield and George A. Kettell, and made oath to the truth of the foregoing statement, by them subscribed, according to their best knowledge and belief.

Before William A. Richardson, Justice of the Peace. 


\section{REPORT}

OF THE

\section{PITTSFIELD \& NORTH ADAMS RAILROAD,}

FOR THE YEAR ENDING NOVEMBER 30, 1861.

Under the Acts of 1849, Chap. 191; 1851, Chap. 102; 1854, Chap. 423 ; 1856, Chap. 165; 1857, Chapters 40, 168 and 240.

Capital Stock.

Number of Shares of capital stock issued..........

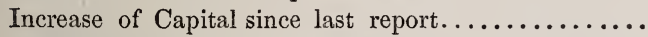

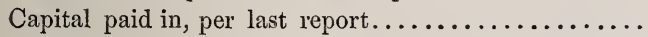

Capital paid in, since last report...............

Total Amount of Capital Stock paid in...........

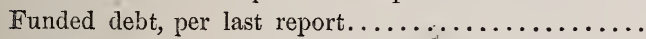

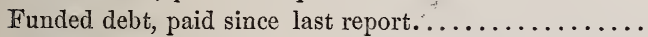

Funded debt, increase of, since last report.........

Total present amount of funded debt.............

Floating debt, per last report...............

Floating debt, paid since last report............

Floating debt, increase of, since last report.........

Total present amount of floating debt.............

Total present amount of funded and floating debt......

Average rate of interest per annum paid during the year.

Maximum amount of debts during the year.........

\section{Cost of Road and Equipment.}

For graduation and masonry, per last report........ For graduation and masonry, paid during the past year. Total amount expended for graduation and masonry.. For wooden bridges, per last report............. For wooden bridges, paid during the past year....... Total amount expended for wooden bridges......... Total amount expended for iron bridges (if any)..... For superstructure, including iron, per last report..... For superstructure, including iron, paid during the

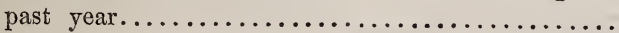

Total amount expended for superstructure, including

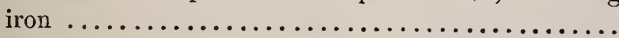

For stations, buildings and fixtures, per last report.... For stations, buildings and fixtures, paid during the

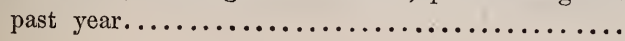

$\$ 500,00000$

4500

$450,000 \quad 00$

450,00000

$108,827 \quad 47$

$108,827 \quad 47$

7,24400

$7,244 \quad 00$

1,30362

201,39531

201,39531 
Total amount expended for stations, buildings and fixtures

29,31133

For land, land damages and fences, per last report....

For land, land damages and fences, paid during the past year.

Total amount expended for land, land damages and

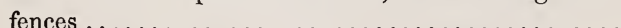

For locomotives, per last report................

For locomotives, paid during the past year..........

Total amount expended for locomotives............

For passenger and baggage cars per last report........

For passenger and baggage cars, paid during the past year ...

Total amount expended for passenger and baggage cars

For merchandise cars, per last report..............

For merchandise cars, paid during the past year......

Total amount expended for merchandise cars........

For engineering per last report.................

For engineering, paid during the past year..........

Total amount expended for engineering.............

For agencies and other expenses per last report.......

For agencies and other expenses paid during the past

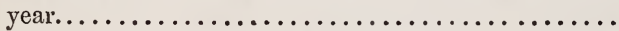

Total amount expended for agencies and other expenses

Total cost of road and equipment..............

Amount of assets of property held by the corporation in addition to the cost of the road...............

$63,742 \quad 95$

63,74295

7,00000

7,00000

$4,247 \quad 43$

4.24743

20,60556

20,60556

Characteristics of Road.

Length of road.

Length of single main track..................

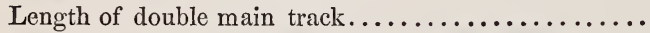

Length of branches owned by the company, stating whether they have a single or double track.........

Aggregate length of sidings, and other tracks, excepting main track and branches....................

Weight of rail per yard, in main road...............

Weight of rail per yard, in branch roads. (Specify the different weights per yard) $\ldots \ldots \ldots \ldots \ldots \ldots \ldots$.

Maximum grade, with its length, in main road.......

Maximum grade, with its length, in branch roads.....

Total rise and fall in main road.................

Total rise and fall in branch roads.................

Shortest radius of curvature, with length of curve, in

main road..............................

Shortest radius of curvature, with length of curve in

branch roads.

Total degrees of curvature in main road............

Total degrees of curvature in branch roads...........

Total length of straight line in main road...........

18.65 miles.

18.65 miles.

0.70 miles.

56 pounds.

$\$ 443,677 \quad 67$

66 feet-222 feet long.

365 feet.

477 1-2 feet-722 feet long.

$710^{\circ}$ 
Total length of straight line in branches...........

Aggregate length of wooden truss bridges..........

Aggregate length of all other wooden bridges........

Aggregate length of iron bridges...............

Whole length of road unfenced on both sides........

Number of public ways crossed at grade...........

Number of railroads crossed at grade............

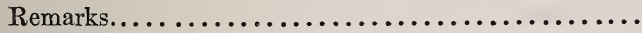

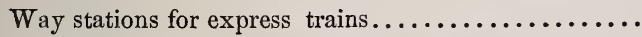

Way stations for accommodation trains...........

Flag stations........................

Whole number of way stations...............

Whole number of flag stations . . . . . . . . . . . .

\section{DoIngs DURING THE Year.}

Miles run by passenger trains............... Miles run by freight trains.................. Miles run by other trains. . . . . . . . . . . . . . Total miles run ....................... Number of passengers carried in the cars.......... Number of passengers, carried one mile........... Number of tons of merchandise carried in the cars.... Number of tons of merchandise carried one mile...... Number of passengers carried one mile to and from

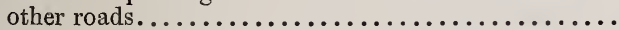

Number of tons carried one mile to and from other roads

Rate of speed adopted for express passenger trains, in-

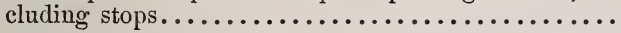

Average rate of speed actually attained by express passenger trains, including stops and detentions........

Rate of speed adopted for accommodation trains......

Rate of speed actually attained by accommodation trains, including stops and detentions...............

Average rate of speed actually attained by special trains,

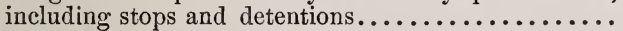

Average rate of speed adopted for freight trains, inclu-

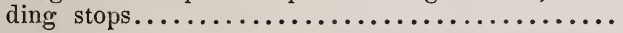

Estimated weight in tons of passenger cars, (not including passengers) hauled one mile..............

Estimated weight in tons of merchandise cars, (not including freight) hauled one mile...............

\section{Expenditures for Working the Road.}

For repairs of road, maintenance of way, exclusive of wooden bridges and renewals of iron............

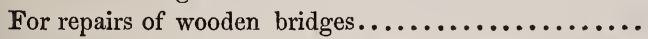

For wages of switchmen, average per month. ....\$26

For wages of gate-keepers, average per month....\$20

For wages of signal men, average per month.....\$20

For wages of watchmen, average per month.....\$30
364 feet.

30 feet.

4 2

4

27.880
27,880

40,259

552,432

19,835

314,280

145,112

265,615
20 miles per hour.

20 miles per hour.

20 miles per hour.

$\$ 3,72903$

6258 
Number of men employed, exclusive of those engaged

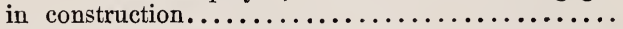

For removing ice and snow, (this item to include all labor, tools, repairs, and extra steam power used)...

For repairs of fences, gates, houses for signal men, gate keepers, switchmen, tool-houses................

Total for maintenance of way..............

Average No. 28.

54000

12500

\section{Motive Power and Cars.}

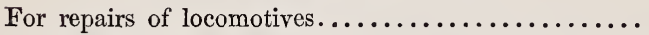

For new locomotives, to cover depreciation..........

For repairs of passenger cars..................

For new passenger cars, to cover depreciation.........

For repairs of merchandise cars. ................

For new merchandise cars, to cover depreciation......

For repairs of gravel and other cars..............

Total for maintenance of motive power and cars. .

Number of Engines....................... I

Number of passenger cars.................. 2

Number of baggage cars................... 1

$\$ 1,47235$

15000

1,13067

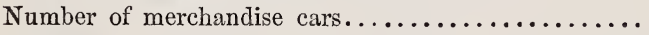

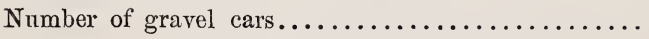

\section{MISCELLANEOUS.}

For fuel used by engines during the year, viz:

Wood, number of cords, $897 \quad$ Cost of the same..

Coal, number of tons, (reckoning 2,240 lbs to the ton,)

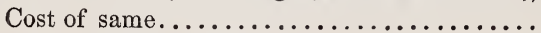

For Oil used by engines and cars................

For waste and other material for cleaning...........

For salaries, wages and incidental expenses, chargea-

ble to passenger department................

For salaries, wages and incidental expenses, chargea-

ble to freight department..................

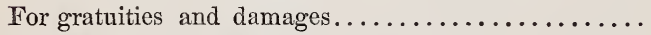

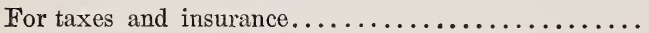

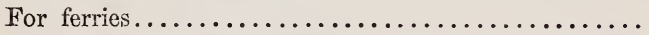

For repairs of station buildings, acqueducts, fixtures,

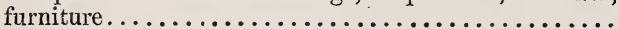

For renewals of iron, including laying down........

For new iron laid down, deducting the value of old iron

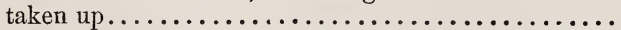

For amount paid other companies, in tolls for passengers and freight carried on their roads, specifying each company ...

For amount paid other companies, as rent for use of their roads, specifying each company.................

For salaries of president, treasurer, superintendent, law expenses, office expenses of the above offices, and all other expenses not included in any of the foregoing items.................................

Total Miscellaneous..................... 
Total expenditures for working the road............

17,47818

Total amount of interest paid during the year........

Income During the Year.

For Passengers :-

1. On main road, including branches owned by company

2. To and from other roads, specifying what.....

$15,965 \quad 07$

For Freight :-

1. On main road and branches owned by company.

2. To and from other connecting roads...........

U. S. Marls ...............................

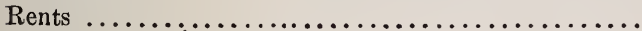

Total income.

Net earnings, after deducting expenses.............

Balance made up by Western Railroad..........

$36,538 \quad 37$

19,06019

7,93981

Dividends.

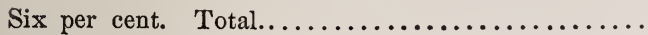

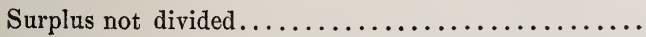

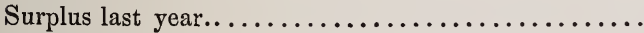

Total Surplus.

Estimated Depreciation beyond the Renewals, $\mathrm{VIZ}$.

Road and Bridges.

Buildings

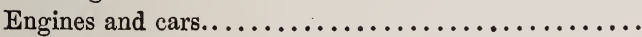

\section{Mortgage Debts.}

Amount of debts secured by mortgage of road and franchise, or any property of the corporation, per last report

Mortgage debt, paid since last report

Mortrage debt, increase of, since last report. .........

Present amount of Mortgage debts ...............

Number of Mortgages on road and franchise, or any property of the corporation.

C. W. CHAPIN, WILLIAM H. SWIFT, ROBERT CAMPBELL, JOSIAH STICKNEY, STEPHEN FAIRBANKS, Directors.

\section{COMMONWEALTH OF MASSACHUSETTS.}

SUFFOLK, ss.

Boston, December 24, 1861.

Then personally appeared C. W. Chapin, William H. Swift, Robert Campbell, Josiah Stickney and Stephen Fairbanks, and severally made oath to the truth of the foregoing statement by them subscribed, 



\section{R F P R T}

OF THE DIRECTORS OE THE

\section{Providence \& Worcester Railroad Corporation,}

FOR THE YEAR ENDING NOVEMBER 30, 1861.

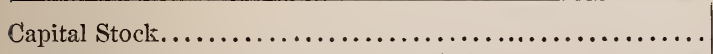

Number of sliares of capital stock issued .........16,000

Increase of capital since last Report..................

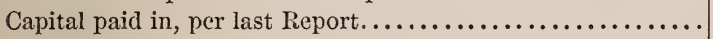

Capital paid in since last Report.

Total amount of capital stock paid in.

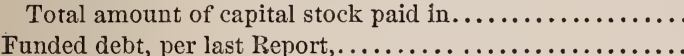

Funded debt, paid since last Report.

Funded debt, increase of, since last Report.

Total present amount of funded debt. ....

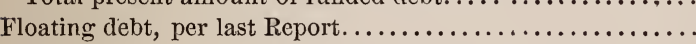

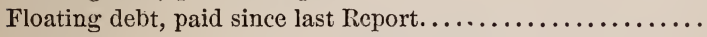

Floating debt, increase of, since last Report.

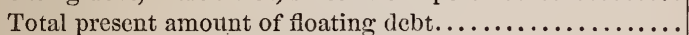

Total present amount of funded and floating debt........

Average rate of interest per annum, paid during the year....

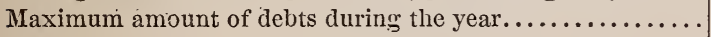

\section{Cost of Road and Equipment.}

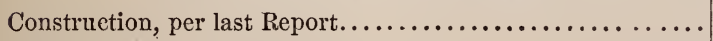

Received during the past year for land......... 6.25

Balance to credit "income," year $1861 \ldots \ldots \ldots \ldots \ldots 6,288.81$

Balance to credit " income," year $1861 \ldots \ldots . . . \ldots \ldots . . .68 .288 .81$

Total present amount of construction $\ldots \ldots \ldots \ldots \ldots \ldots \ldots$
$\$ 1,600,000.00$

None.

$1,560,200.00$

$39,800.00$

$200,000.00$

$53,000.00$

$147,000.00$

None.

6 per cent.

$\$ 1,442,470.59$

$6,295.06$

(1)


For graduation and masonry, per last Report..............

For graduation and masonry, paid during the past year....

Total amount expended for graduation and masonry....

For wooden bridges, paid during the past year.............

Total amount expended for wooden bridges..............

Total amount expended for iron bridges, (if any)..........

For superstructure, including iron, per last Report..........

For superstructure, including iron, paid during the past year

Total amount expended for superstructure, including iron.

For stations, buildings and fixtures, per last Report.........

For stations, buildings and fixtures, paid during the past year

Total amount expended for stations, buildings and fixtures

For land, land-damages and fences, per last Report.........

For land, land-damages and fences, paid during the past year

Total amount expended for land, land-damages and fences.

For locomotives, per last Report.......................

For locomotives, paid during the past year...............

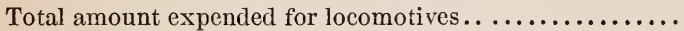

For passenger and merchandise cars, per last Report.........

For passenger and merchandise cars, paid during the past year

Total amount expended for passenger and merchandise cars.

For merchandise cars, per last Report...................

For merchandise cars, paid during the past year............

Total amount expended for merchandise cars .............

For engineering, per last Report.......................

For engineering, paid during the past year.................

Total amount expended for engineering.

For agencies and other expenses, per last Report...........

For agencies and other expenses paid during the past year...

Total amount expended for agencies and other expenses...

Total present amount of construction and equipment......

Amount of assets or property held by the corporation in addition to the cost of the road........................

\section{Characteristics of Road.}

Length of road ...

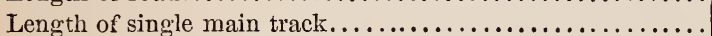

Length of double main track...........................

Length of branches owned by the Company, stating whether they have a single or double track....................

Aggregate length of sidings, and other tracks, excepting main tracks and branches..........................

Weight of rail per yard, in main road...................

Weight of rail per yard, in branch roads, (specify the different

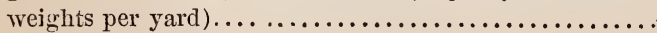

Maximum grade, with its length in, main road............

Maximum grade, with its length in branch roads............

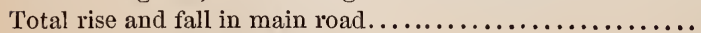

Total rise and fall in branch roads........................

Shortest radius of curvature, with length of curve, in main

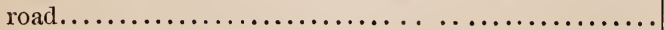

Shortest radius of curvature, with length of curve in branch

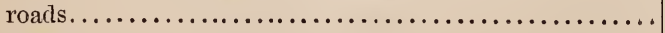

Total degrees of curvature, in main road................
$105,642.46$

$8,250.00$

$113,892.46$

$148,923.08$

None.

$148,923.08$

$1,698,991.07$

43 41-100 miles.

37 miles.

6 41-100 miles.

One.

81-2 miles.

56 to 63 pounds.

$27 \mathrm{ft}$. per mile for $4300 \mathrm{ft}$.

Rise, 526 feet; fall $56 \mathrm{ft}$.

716 feet for 875 feet.

$2546^{\circ} 30^{\prime}$ 
Total degrees of curvature, in branch roarls.

Total length of straight line, in main road

Total length of straight line, in branches.

Aggregate length of wooden truss bridges................

Aggregate length of all other wooden bridges..............

Aggregate length of iron bridges.......................

Whole length of road unfenced on both sides................

Number of public ways crossed at grade...................

Number of railroads crossed at grade...................

Remarks.......................................

Way stations for express trains.

Way stations for accommodation trains...................

Flag stations....................................

Whole number of way stations......................

Whole number of flag stations...................... 3

\section{DoINGS DURING The Year.}

Miles run by passenger trains.

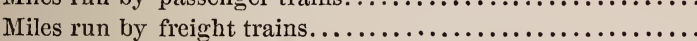

Miles run by other trains.

Total miles run.

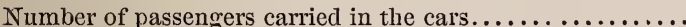

Number of passengers carried one mile..................

Number of tons of merchandise carried in the cars ..........

Number of tons of merchandise carried one mile.

Number of passengers carried one mile, to and from other roads.

Number of tons carried one mile, to and from other roads. .

Rate of speed adopted for express passenger trains, including stops......................................

Average rate of speed actually attained by express passenger

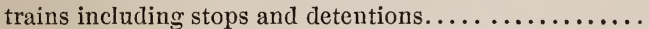

Rate of speed adopted for accommodation trains.

Rate of speed actually attained by accommodation trains, in

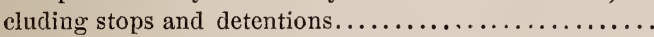

Average rate of speed actually attained by special trains, including stops and detentions.

Average rate of speed adopted for freiglt trains, including stops.

Estimated weight in tons of passenger cars (not including passengers) hauled one mile.......................

Estimated weight in tons of merchandise cars (not including freight) hauled one mile.

\section{EXPENDITURES FOR WORKIXG THE ROAD.}

For repairs of road, maintenance of way, exclusive of wooden bridges, and renewals of iron.......................

For repairs of wooden bridges........................

For wages of switchmen, average per month............

For wages of gate-keepers, average per month............

For wages of signal-men, average per month............

For wages of watchmen, average per month.............

Number of men employed, exclusive of those engaged in construction...................................
28 3-4 miles.

3855 feet.

1300 feet.

None.

None.

43

1

None run.

18

3

18

124,149

80,994

None.

617,584

205,143

$5,200,259$

141,753

$4,571,036$

203,787

$1,393,218$

20 miles per hour.

25 miles per hour.

10 miles per hour.

$3,050,300$

$8,250,090$

The duties of these men are mixed up with other duties as station laborers. 
For removing ice and snow, (this item to include all labor, tools, repairs, and extra steam-power used)...

For repairs of fences, gates, houses for signal-men, gatekeepers, switchmen, tool-houses....................

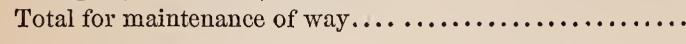

\section{- Motive Power and Cars.}

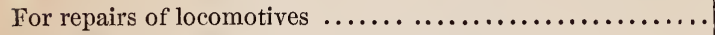

For new locomotives, to cover depreciation...............

For repairs of passengers cars. . . . . . . . . . . . . . . . . . . . . .

For new passenger cars, to cover depreciation.............

For repairs of merchandise cars..........................

For new merchandise cars.............................

For repairs of gravel and other cars $\ldots \ldots \ldots \ldots \ldots \ldots \ldots \ldots . . .6$.

Total for maintenance of motive power and cars.........

Number of engines................................

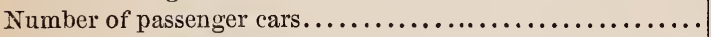

Number of baggage cars. .............................

Number of merchandise cars...........................

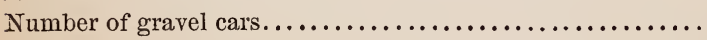

\section{Miscellaneous.}

For fuel used by engines during the year, viz:

Wood, number of cords, 300 . Cost of the same, $\$ 1,050.00$ )

Coal, number of tons, (reckoning 2,240 lbs. to the ton,) $\left.{ }^{\prime}\right\}$

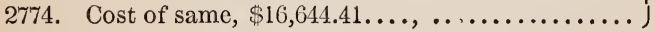

For oil used by cars and engines.......................

For waste and other material for cleaning.................

For salaries, wages and incidental expenses, chargeable to passenger department............................

For salaries, wages and incidental expenses, chargeable to freight department...............................

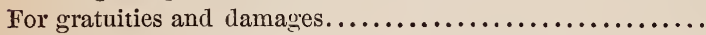

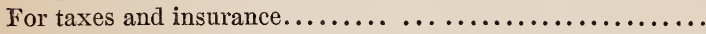

For ferries......................................

For repairs of station buildings, acqueducts, fixtures, furniture

For renewals of iron, including laying down.............

For new iron laid down, deducting the value of old iron taken up..........................................

For amount paid other companies, in tolls for passengers and freight carried on their roads, specifying each company..

For amount paid other companies, as rent for use of their roads, specifying each company.

For salaries of President, Treasurer Superintendent, law expenses, office expenses of the above offices, and all other expenses not included in any of the foregoing items.....

Total miscellaneous............................

Total expenditures for working the road..................

Total amount of interest paid during the year..............
$41,580.02$

$\$ 15,884.37$

$2,800.47$

$5,930.05$

$6,773.77$

$31,388.66$

$\$ 17,694.41$

$2,819.18$

743.32

$21,462.73$

27,169.92

425.00

$2,466.08$

6,019.23

$17,012.58$

$95,812.45$

$168,781.13$

$10,810.92$

5,65283 


\section{INCOME DURING THE YEAR.}

For Passengers:

1. On main road, including branches owned by company.

$\$ 120,081.79$

2. To and from other roads, specifying what...

For Freight:

1. On main road and branches owned by the company

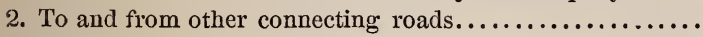

U. S. Mails. ....................................

Rents.................................................

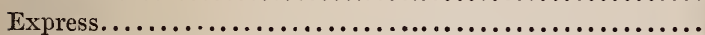

Total income...................................

Net earnings, after deducting expenses................

\section{DIVIDENDS.}

8 per cent. Total

Surplus not divided.................................

Surplus last year.................................

Total surplus...................................

$175,614.62$

$5,114.25$

$2,140.37$

$5,277.00$

$308,228.03$

$139,446.90$

None.

None.

None.

\section{Estimated Depreciation beyond the Renewals, viz}

Of road and bridges.

Buildings and cars.

\section{Mortgage Debts.}

Amount of debts secured by mortgage of road and franchise, or any property of the corporation, per last Report......

Mortgage debt, paid since last Report.....................

Increase of mortgage debt since last Report................

Present amount of mortgage debts.....................

Number of mortgages on road and franchise, or any property of the Corporation. 


\section{RECORD OF ACCIDENTS}

On the Providence \& Worcester Railroad, for the year ending Nov. 30, 1861.

December 29, 1860. Dennis Tonney, on the night of December 29, having fallen in a cattle guard, and being unobserved by the engineer, was killed by a passing locomotive. The accident occurred in the city of Providence.

Oстовеr 19, 1861. Ann Ferguson, (intoxicated,) while lying upon the track near Pawtucket, was run over by a car used by a repair party, and injured. The night being dark, she was not discovered in season to prevent the collision.

Respectfully submitted by

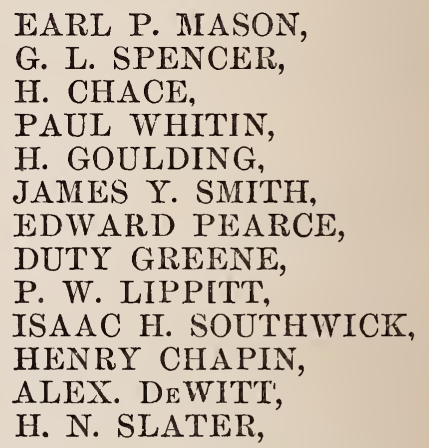

Directors of the Providence \& Worcester Ruilroad Company.

Providence, R. I., December 21st, 1861.

Providence, ss. December 21, 1861.

Then personally appeared the persons whose names are subscribed to this report, and severally made oath to the truth of the foregoing statement by them subscribed. Before

HENRY L. BOWEN, Justice of the Peace.

Providence, December 23d, 1861.

The undersigned, Commissioners of the Providence and Worcester Railroad Company having examined this Report, believe it to be correct, and herewith approve the same.

WILLIAM S. DENNY,

Commissioner for Massachusetts.

JOHN R. BARTLETT,

Commissioner for Rhode Island. 


\section{Report of the Commissioners of the Providence and Worcester Railroad Company to the Legislatures of Massachusetts and Rhode Island.}

At a meeting of the Commissioners of the Providence and Worcester Railroad Company, at the Company's office in Providence, on the 23d day of December, 1861, for the purpose of investigating the accounts and expenditures of said Company, and for deciding what sums are applicable to that part of the road lying in the State of Rhode Island, and also what part is chargeable to that portion of the road lying in Massachusetts; and having examined the accounts of said Company, we find that the net expenditures for construction and equipment to the thirtieth of November, 1860, were

There has been expended, during the year, for the purchase of one locomotive $\$ 1,697,036.13$

$\$ 1,705,286.13$

From which should be deducted for the sale of real estate........ 6.25

Net earnings of the road from Nov. 30,1860 to Nov. $30,1861 \ldots \ldots .139,446.90$

$$
139,453.15
$$

Less interest on funded debt $\ldots \ldots \ldots \ldots \ldots \ldots \ldots \ldots \ldots, 5,158.09$

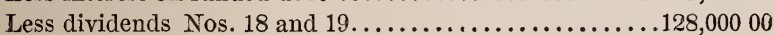

Net cost of road and equipments, to Nov. 30,1861 $\$ 1,698,991.07$

Apportioned as follows, viz :

To Massachusetts..........................................\$849,495.53

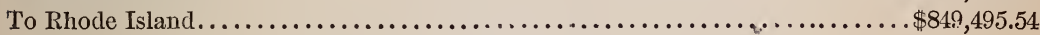

\section{RECEIPTS.}

The whole amount of receipts from the 30 th November, 1860, to 30 th November, 1861, is as follows, viz:

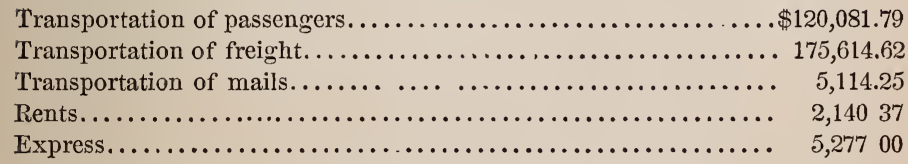

$\$ 308,228.03$

\section{EXPENSES}

For maintaining and operating the road during the twelve months ending November 30,1861 .

Fuel. $\$ 17,694.41$

Oil.................................... $2,819.18$

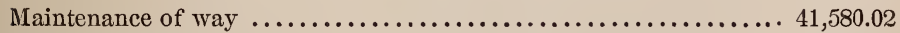

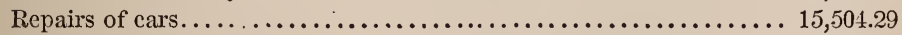

Repairs of locomotives........................... 15,884.37

Passenger expenses.............................. 21,462.73

Freight expenses............................ 27,169.92

Miscellaneous expenses. .......................... 26,666.21

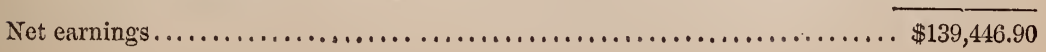


Which sum we apportion as follows, viz :

To Massachusetts.

To Rhode Island

Said Commissioners also find on examining the books of said Company that separate accounts of the expenditures in Rhode Island and Massachusetts have been kept agreeable to the acts of said States creating the present Providence and Worcester Railroad Company.

WM. S. DENNY,

Commissioner for Massachusetts.

JOHN R. BARTLETT,

Commissioner for Rhode Island. 


\section{R E P O R T}

OF THE DIRECTORS OF THE

\section{Providence, Warren and Bristol Railroad Corporation,}

FOR THE YEAR ENDING NOVEMBER 30, 1861.

\begin{tabular}{|c|c|c|}
\hline Capital Stock...................................... & & \multirow[t]{2}{*}{$\$ 442,000.00$} \\
\hline Number of shares of capital stock issued $\ldots \ldots \ldots \ldots \ldots \ldots \ldots$ & & \\
\hline Increase of capital since last Report.................... & - & \\
\hline Capital paid in, per last Report........................ & $\$ 437,9,17.49$ & \multirow{4}{*}{$437,917.49$} \\
\hline Capital paid in since last Report.......................... & \multirow{4}{*}{$8,500.00$} & \\
\hline Total amount of capital stock paid in.............. & & \\
\hline Funded debt, per last Report..................... & & \\
\hline Funded debt, paid since last Report................. & & \multirow{4}{*}{$8,500.00$} \\
\hline Funded debt, increase of, since last Report............ & \multirow{9}{*}{$\begin{array}{l}\text { None. } \\
\text { None. }\end{array}$} & \\
\hline Total present amount of funded debt.............. & & \\
\hline Floating debt, per last Report..................... & & \\
\hline Floating debt, paid since last Report.............. & & \multirow{6}{*}{$8,500.00$} \\
\hline Floating debt, increase of, since last Report.......... & & \\
\hline Total present amount of floating debt.............. & & \\
\hline Total present amount of funded and floating debt......... & & \\
\hline Average rate of interest per annum, paid during the year.... & & \\
\hline Maximum amount of debts during the year............. & & \\
\hline COST OF ROAD AND EQUIPMENT. & & \\
\hline For graduation and masonry, per last Report....... & $144,591.89$ & \\
\hline For graduation and masonry, paid during the past yea & None. & \\
\hline Total amount expended for graduation and masonry & & $144,591.89$ \\
\hline For wooden bridges, per last Report.................. & $8,616.10$ & \\
\hline For wooden bridges, paid during the past year.. & None. & \\
\hline
\end{tabular}

Total amount expended for wooden bridges. 
Total amount expended for iron bridges, (if any) None.

For superstructure, including iron, per last Report...........

For superstructure, including iron, paid during the past year

Total amount expended for superstructure, including iron.

For stations, buildings and fixtures, per last Report.........

For stations, buildings and fixtures, paid during the past year

Total amount expended for stations, buildings and fixtures

For land, land-damages and fences, per last Report.........

For land, land-damages and fences, paid during the past year

Total amount expended for land, land-damages and fences.

For locomotives, per last Report.......................

For locomotives, paid during the past year...............

Total amount expended for locomotives.................

For passenger and baggage cars, per last Report............

For passenger and baggage cars, paid during the past year....

Total amount expended for passenger and baggage cars.....

For merchandise cars, per last Report....................

For merchandise cars, paid during the past year............

Total amount expended for merchandise cars ............

For engineering, per last Report........................

For engineering, paid during the past year................

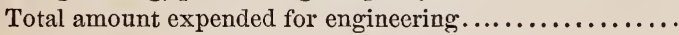

For agencies and other expenses, per last Report...........

For agencies and other expenses paid during the past year...

Total amount expended for agencies and other expenses...

Total cost of road and equipment......................

Amount of assets or property held by the corporation in addition to the cost of the road.......................

\section{Characteristics of Road.}

Length of road.....................................

Length of single main track..........................

Length of double main track..........................

Length of branches owned by the Company, stating whether they have a single or double track....................

Aggregate length of sidings, and other tracks, excepting main tracks and branches.........................

Weight of rail per yard, in main road....................

Weight of rail per yard, in branch roads, (specify the different

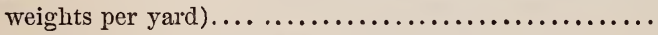

Maximum grade, with its length, in main road.............

Maximum grade, with its length in branch roads...........

Total rise and fall in main road........................

Total rise and fall in branch roads......................

Shortest radius of curvature, with length of curve, in main

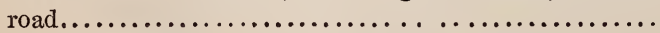

Shortest radius of curvature, with length of curve in branch roads..........................................

Total degrees of curvature, in main road.................

Total degrees of curvature, in branch roads...............

Total length of straight line, in main road................

Total length of straight line, in branches................. 
Aggregate length of wooden truss bridges............... Aggregate length of all other wooden bridges.............. Aggregate length of iron bridges........................ Whole length of road unfenced on both sides............... Number of public ways crossed at grade.................. Number of railroads crossed at grade.................... Remarks.

Way stations for express trains.

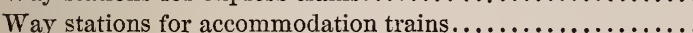

Flag stations

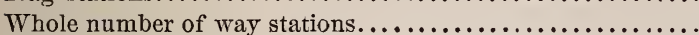

Whole number of flag stations.........................

\section{DoINgs DURING THE Year.}

Miles run by passenger and freight trains.

Miles run by freight trains.

Miles run by other trains.

Total miles run.

Number of passengers carried in the cars................

Number of passengers carried one mile..................

Number of tons of merchandise carried in the cars ..........

Number of tons of merchandise carried one mile............

Number of passengers carried one mile, to and from other roads......................................

Number of tons carried one mile, to and from other roads...

Rate of speed adopted for express passenger trains, including

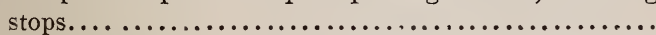

Average rate of speed actually attained by express passenger trains including stops and detentions.................

Rate of speed adopted for accommodation trains............

Rate of speed actually attained by accommodation trains, including stops and detentions.......................

Average rate of speed actually attained by special trains, including stops and detentions......................

Average rate of speed adopted for freight trains, including

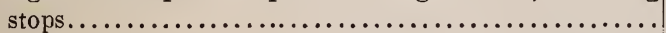

Estimated weight in tons of passenger cars (not including passengers) hauled one mile.......................

Estimated weight in tons of merchandise cars (not including freight) hauled one mile.

\section{Expenditures for WORKING the RoAd.}

For repairs of road, maintenance of way, exclusive of wooden bridges, and renewals of iron........................

For repairs of wooden bridges........................

For wages of switchmen, average per month...........

For wages of gate-keepers, average per month...........

For wages of signal-men, average per month...........

For wages of watchmen, average per month............

Number of men employed, exclusive of those engaged in
310 feet.

162 feet.

None.

None.

11

None.

\section{None.}

4

3

7

3

24,471 miles.

None.

76,750

885,125

4,347

56,862

56,672

8,255

No express trains.

24 miles per hour.

17 miles per hour.

Mixed trains.

453,416

300,620

$\$ 6,174.29$

48.30

$1,159.00$ 
For removing ice and snow, (this item to include all labor, tools, repairs, and extra steam-power used).

For repairs of fences, gates, houses for signal-men, gatekeepers, switchmen, tool-houses.....................

Total for maintenance of way......................

\section{Motive Power and Cars.}

For repairs of locomotives

For new locomotives, to cover depreciation...............

For repairs of passengers cars. . . . . . . . . . . . . . . . . . . . .

For new passenger cars, to cover depreciation..............

For repairs of merchandise cars........................

For new merchandise cars...........................

For repairs of gravel and other cars ...................

Total for maintenance of motive power and cars..........

Number of engines.................................

Number of passenger cars............................ 3

Number of baggage cars............................. 1

Number of merchandise cars........................ 3

Number of gravel cars............................ 2

\section{Miscellaneous.}

For fuel used by engines during the year, viz:

Wood, number of cords, 62 . Cost of the same............

Coal, number of tons, (reckoning 2,240 lbs. to the ton,)

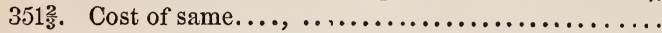

For oil used by cars and engines.........................

For waste and other material for cleaning.................

For salaries, wages and incidental expenses, chargeable to passenger department............................

For salaries, wages and incidental expenses, chargeable to freight department.............................

For gratuities and damages............................

For taxes and insurance...........................

For ferries....................................

For repairs of station buildings, acqueducts, fixtures, furniture For renewals of iron, including laying down..............

For new iron laid down, deducting the value of old iron taken up.........................................

For amount paid other companies, in tolls for passengers and freight carried on their roads, specifying each company..

For amount paid other companies, as rent for use of their roads, specifying each company...

For salaries of President, Treasurer Superintendent, law expenses, office expenses of the above offices, and all other expenses not included in any of the foregoing items.....

Total miscellaneous.............................

Total expenditures for working the road.................

Total amount of interest paid during the year, balance of interest acct.
$7,381.59$

$\$ 484.48$

894.37

270,00

$1,648.85$

$\$ 325,55$

1,846.22

445.73

56.61

$4,005.00$

$1,711.58$

193.56

431.50

137.46

$1,357.17$

$10,510.38$

$19,540.82$

215.52 


\section{INCOME DURING THE YeAR.}

For Passengers :

1. On main road, including branches owned by company...

2. To and from other roads, specifying what. Boston \&

Stonington, and T. B. \& N. B. Railroad..............

For Freight:

1. On main road and branches owned by the company.......

2. To and from other connecting roads...................

U. S. Mails......................................

Express............................................

Total income...................................

Net earnings, after deducting expenses..................

\section{Dividends.}

per cent. Total.................................

Surplus not divided.................................

Surplus last year.....................................

Total surplus....................................

Estimated Depreciation beyond the Renewals, viz: Of road and bridges................................. Buildings, engines and cars...........................

\section{Mortgage Debts.}

Amount of debts secured by mortgage of road and franchise, or any property of the corporation, per last Report......

Mortgage debt, paid since last Report....................

Increase of mortgage debt since last Report...............

Present amount of mortgage debts.......................

Number of mortgages on road and franchtse, or any property of the Corporation.

\section{$\$ 16,979.04$}

$1,864.05$

$2,122.38$

$4,390.10$

498.75

600.00

$26,454.32$

$6,697.98$

$8 ; 500.00$

$8,500.00$

Directors of the Providence, Warren \& Bristol Railroad Corporation Providence, R. I., December 21 st, 1861.

\section{Providence, ss. December 21, 1861.}

Then personally appeared C. T. Child, Sam'l W. Church, Thos. G. Turner, Amos D. Smith, Robert H. Ives, and Leon Chappotin, and severally made oath io the truth of the foregoing statement by them subscribed. Before me

JOHN A. GARDNER, Justice of the Peace. 
Report of the Commissioners of the Providence, Warren and Bristol Railroad Company to the Legislatures of Massachusetts and Rhode Island.

At a meeting of the Commissioners of the Providence, Warren \& Bristol Railroad Company, at the Company's office in Providence, on the 23d day of December, 1861, for the purpose of investigating the accounts and expenditures of said Company, and for deciding what sums are applicable to that part of the road laying in Massachusetts, and also what part is chargeable to that portion of the road laying in Rhode Island; and having examined the accounts of said Company, we find that the total expenditures for construction and equipment to the thirtieth of November, 1861, inclusive, are

$\$ 448,166.87$

The amount of cost of construction we apportion as follows :

To Massachusetts.............................................\$115,190.38

To Rhode Island.......................................... \$332,976.49

RECEIPTS.

The whole amount of receipts from December 1st, 1860, to November 30 th, 1861, inclusive, was as follows, viz:

For transportation of passengers........................\$18,843.09

For transportation of freight. $\ldots \ldots \ldots \ldots \ldots \ldots \ldots \ldots \ldots \ldots \ldots, 6,512.48$

For Mails and Express............................... 1,098.75

$\$ 26,454.32$

EXPENSES

Which we apportion as follows, viz :

$\$ 19756.34$

To Massachusetts.

$\$ 5,323.11$

To Rhode Island.

$\$ 14,433.23$

Said Commissioners find on examining the books of said Company, that said Company have kept separate accounts of the expenditures in Massachusetts and Rhode Island, respectively, agreeable to the laws of said States.

JOHN C. PRATT,

Commissioner for Massachusetts.

JOHN A. GARDNER,

Commissioner for Rhode Island. 




\title{
ANNUAL REPORT
}

\author{
OF THE
}

\section{ROCKPORT RAIL ROAD.}

FOR TH'E YEAR RNDING

NOVEMBER $30,1861$.

\section{S A L T M :}

WM. IVES AND GEO. W. PEASE.. ..PRINTERS,

1861. 



\title{
R E P O R T
}

\author{
OF THE DIRECTORS OF THE
}

\section{ROCKPORT RAILROAD CORPORATION,}

\section{For the Year Ending November 30, 1861.}

To be returned to the Secretary of the Commonwealth, together with 1000 printed copies of the same, on or before the first Wednesday in January next.

[General Statutes, Chap. 63, Sections 132 to 135.

Capital Stock,

Number of shares of capital stock issued, .

Increase of Capital, since last Report, . . .

Capital paid in, per last Report, . . . .

Capital paid in, since last Report, . . .

Total amount of capital stock paid in, . . .

Funded debt, per last Report, . . . .

Funded debt, paid since last Report, . . .

Funded debt, increase of, since last Report, .

Total present amount of funded debt, . . .

Floating debt, per last Report, . . . .

Floating debt, paid since last Report, . . .

Floating debt, increase of, since last Report, .

Total present amount of floating debt, .

Total present amount of funded and floating debt,

Average rate of interest per annum, paid during the

Maximum amount of debts during the year, ·

\section{Cost of Road and EQUipnent.}

For graduation and masonry, per last Report,

For graduation and masonry, paid during the past year

Total थwount expended for graduation and masonry,

For wou le $n$ bridges, per last Report, .

For wooden bridges, paid during the past year, .

Total amourt expended for wooden bridges,

Total amount expended for iron bridges (if any)

For superstructure including iron, per last Report,

For superstructure, including iron, paid during the past year,

Total amouat expended for superstructure, including

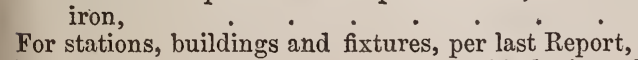

For stations, buildings and fixtures, paid during the past year,

Total amount expended for stations, buildings and fixtures,
$\$ 61,40000$

563

3,60000

12,28000

50,20000

$\$ 62,48000$ 
For land, land clamages and fences, per last Report, For land, land damages and fences, paid during the

Total amount expended for land, land-damages and fences,

For locomotives, per last Report, ${ }^{\circ} \quad$ · $^{\circ} \cdot{ }^{\circ}$

For locomotives, paid during the past year, :

Total amount expended for locomotives, . .

For passenger and baggage cars, per last Report, .

For passenger $\&$ baggage cars, paid during the past year

Total amount expended for passenger and baggage cars

For merchandise cars, per last Report,

For merchandise cars, paid during the past year,

Total amount expended for merchandise cars, .

For engineering, per last Report, . . .

For engineering, paid during the past year, .

Total amount expended for engineering,

For agencies and other expenses, per last Report,
For agencies and other expenses paid during the past year,

Total amount expended for agencies and other expenses

Total cost of road and equipment,

Amount of assets or property held by the corporation in addition to the cost of the road,

\section{Charagteristics of Road。}

Length of road,

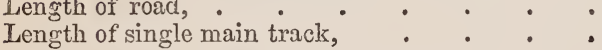

Length of double main track, $\quad . \quad \therefore \quad: \quad$ :

Length of branches owned by the Company stat- ?

ing whether they have a single or double track.

Aggregate length of sidings, and other tracks, excep-

3 6-10 Miles.

19.700 feet. ting main tracks and branches,

Weight of rail, per yard, in main road,

Weight of rail, per yard, in branch roads, (specify the different weights per yard)

Maximum grade, with its length in main road, :

Maximum grade, with its length, in branch roads,

Total rise and fall in main road, . . . .

Total rise and fall in branch roads.
Shortest radius of curvature, with length of curve, in main road,

Shortest radius of curvature, with leggth of curve, in

branch roads,
Total degrees of curvature, in main road, : :

Total degrees of curvature, in branch roads, .

Total length of straight line, in main road, .

Total length of straight line in branches

1690 feet.

50 pounds.

$50 \mathrm{ft}$. to mile\%

122 feet.

1353 feet.

299

12.485

Aggregate length of wooden truss bridges, .

Aggregate length of all other wooden bridges, .

Aggregate length of stone bridge,

Whole length of road unfenced on both sides,

Number of public ways crossed at grade, .

Number of railroads crossed at grade, : :

Remarks,

Way stations for express trains,

Way stations for accommodation trains, :

Flag stations,

Whole number of way stations,

Whole number of flag stations, $: \quad \cdot \quad:$ 


\section{DoIngs DuRing tere Year.}

Miles run by passenger trains, - - : -

Miles run by other trains, Total miles run, - - $\quad$ -

Number of passengers carried in the cars, -

Number of passengers carried one mile, - -

Number of tons of merchandise carried in the cars,

Number of tons of merchandise carried one mile,

Number of passengers carried one mile, to and from other roads,

Number of tons carried one mile, to and from other roads,

Rate of speed adopted for express passenger trains, including stops

Average rate of speed actually attained by express passenger trains, including stops and detentions,

Rate of speed adopted for accommodation trains,

Rate of speed actually attained by accommodation trains, including stops and detentions,

Average rate of speed actually attained by special trains, including stops and detentions,

Average rate of speed adopted for freight trains, including stops,

Estimated weight in tons of passenger cars (not including passengers) hauled one mile,

Estimated weight in tons of merchandise cars (not including freight) hauled one mile,

\section{Expenditures. For Worting the RoAd.}

For repairs of road, maintenance of way, exclusive of wooden bridges, and renewals of iron,

For repairs of wooden bridges, -

For wages of switchmen, av. per month,
For wages of gate-keepers, av. per month,

For wages of signal-men, av. per month,

For wages of watchmen, av. per month,

Number of men employed, exclusive of those engaged in construction,

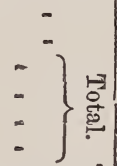

For removing ice and snow, (this item to include all labor, tools, repairs, and extra steam-power used,)

For repairs of fences, gates, houses for signal-men, gate-keepers, switchmen, tool-houses,

Total for maintenance of way,

\section{Motive Power and Cars.}

For repairs of locomotives,

For new locomotives, to cover depreciation,

For repairs of passenger and freight cars,

For new passenger cars, to cover depreciation,

For repairs of merchandise cars, - - -

For new merchandise cars, to cover depreciation,

For repairs of gravel and other cars, Total for maintenance of motive power and cars,

Number of engines,

Number of passenger cars,

Number of baggage cars, -

Number of merchandise cars,

Number of gravel cars, 


\section{Miscellaneous.}

For fuel used by engines during the year, viz.:-

1. Wood, number of cords, Cost of the same,

2. Coal, number of tons, (reckoning 2,240 lbs, to the ton,) Cost of the same,

For oil used by cars and engines, gallons,

For waste and other material for cleaning,

For salaries, wages and incidental expenses, chargeable to passenger department,

For salaries, wages, and incidental expenses, chargeable to freight department,

For gratuities and damages,

For tares and insurance

For ferries,

For repairs of station buildings, aqueducts, fixtures, furniture, and other station expenses,

For renewals of iron, including laying down,

For new iron laid down, deducting the value of old iron taken up,

For amount paid other companies, in tolls for passengers and freight carried on their roads, specifying each company,

For amount paid other companies, as rent for use of their roads, specifying each company,

For salaries of president, treasurer, superintendent, law expenses, office expenses of the above offioes, and all other expenses not included in any of the foregoing items,

Total Miscellaneous,

Total expenditures for working the road,

Total amount of interest paid during the year.

\section{Ixcone Derisg the Teat.}

For Passengers :-

1. On main road, including branches owned by ?

2. To and from other roads, specifying what - -$\}$

For Freight:-

1. On main road and branches owned

by company,

2. To and from other connecting roxds

U. S. Mails,

Rents- -

Total income,

Net earnings after deducting expenses,

\section{Per cent}

Surplus not divided, Surplus last year -

Dividends.

Total surplus, - $\quad-\quad$ - $\quad$ -


Estrmated Depreciation Bexond the Renewals, viz.

Of road and bridges,

Buildings,

Engines and cars,

\section{Mortgage Debts.}

Amount of debts secured by mortgage of road and franchise, or any property of the Corporation, per last Report,

Iortgage debt paid since last Report

Increase of mortgage debt since last Report, -

Present amount of mortgage debts,

Number of mortgages on road and franchise, or any property of the corporation, -

$\left.\begin{array}{l}\text { NEWELL GILES, } \\ \text { MOSES HASKINS, } \\ \text { ADDISON GOTT, } \\ \text { HENRY DENNIS, } \\ \text { EZRA EAMES, } \\ \text { JAMES MANNING, } \\ \text { JOHN PRESTON, }\end{array}\right\} \begin{gathered}\text { Dockport Railroad } \\ \text { of the } \\ \text { Corporation. }\end{gathered}$

Essex, ss. December 27, 1861. Then personally appeared Newell Giles, Moses Haskins, Addison Gott, Henry Dennis, Ezra Lames, James Manning, and John Preston, and severally made oath, that the foregoing statement by them subscribed is true, according to their best knowledge and belief. Before me,

ALTRED PARSONS, Justice of the Peace. 



\title{
THIRTEENTH ANNUAL REPORT
}

\author{
OF THE DIRRCTORS OF THE
}

\section{Salem and Lowell Railroad Company,}

FOR THE YEAR ENDING NOVEMBER 30, 1861.

\section{Capital Stock,}

Number of shares of capital stock issued,

Increase of capltal since last report,

Capital paid in, per last report,

Capital pald in, sunce list report,

Total anuunt of cajital stock paid in

Funded debt, per last repurt

Fumlerl debt, jaid since lisst report,

Funded debt, increase of, since last report,

Total present amount of funded debt,

Floating debt, per last report,

Floating debt, paid slnce last report,

Floating debt, increase it, since last report,

Total prosell amount of floating debt heing nnpaid dividends

Total present amount of funded an 1 floating delts.

Averago rite of Interest per annum, fraid during the year,

Maximutu amount of debts during the year,

Surplus-Contra,

\section{COST OF ROAD AND EQUIPMENT.}

For graduation and masonry, per last report,

For graduation and masonry, paid during the past year,

Tutal amount expended for gladuation and masonry,

For wuoden bridges, per last report,

For woolen liridges, paid during the past year,

T'otal amount expended for wooden briclges,

Total itmoust expended for iron briclges (if any),

For superstructure, jncluding irun, per last report,

For supeestructure, including iron, paid during the past year,

Tutal amount expended for superstructure, including iron,

For statiulıs, buildings anl fixtures, per last repurt,

For stations, buillings aud fixtures paid during the past year, Totill anumint expended for stations, buildings and fixtures,

For land, laul-damages and lences, pel last report,

For land, land dimnages and fences, mid during the past year, Total amount expended lor land, land-dumages and fences,

For locomotives, per last repurt,

For lucomolires, paid during the past year,

T'ut:il amount expended fur locomitives,

For jassenger ant lagggine cars, per last report,

For passenger and baggige ears, paticl during the rast year,

Total anount expencled for prassenger and baggage cars,

For merchandise cars, per last rinport,

For merelumdise cars, paid during the past year,

Tutal amount expeided for merchandise cars,

For ellguleuring, per last report,

For engineering, jaicl duling the past year,

Tutill amount expended for engineering,

For agencies and other expenses, per last report,

For agencies and other expe'nses, piaid during the past year,

lotal amount expended for agencies and other expenses,
$\$ 400,00000$

2,433

None.

243,80500

None.

226,90000

None.

None.

226.90000

34091

7079

None.

27012

6 per cent. 227,24091

$22:, 17012$

243,30500

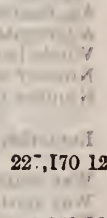

6,65016

477,12528

94,831 77

Nothing.

3, 13915

94,831 7\%

Nothing.

Nothing.

123,80118

Nothing.

8.39913

Nothing.

Nothing.

48,00725

Nothing.

$21,94855 \quad 48,00725$

3,13915

123,80118

8,39913

21,94853

$7,+2062$

Nothing.

\begin{tabular}{l|c}
$\begin{array}{c}\text { Nothing. } \\
53,17422\end{array}$ & $\mathbf{7 , 4 2 0 6 3}$ \\
Nothing. & \\
6,927 57 & 53,17422 \\
Nothing. & 6 \\
6,02635 & 6,02757 \\
Nothing. & \\
\hline
\end{tabular}

6,02635 
Discount on bonds, and mlscellaneous,

Tutal cost of road and equipment,

Amount of assets or property held by the corporation in addition the the cost of the road,

of the $\$ 13,11206$ assete $\$ 4,98441$ is considered unavailable.

$\$ 464,01322$

13,11206

$\$ 477,12528$

\section{CHARACTERISTICS OF ROAD.}

Length of road,

Leng: $h$ of single main track,

Length of double main track,

Length of branches owned by the Company, stating whether they have a single or double track,

Aggregate length of sidlngs, and other tracks, excepting main tracks and branches,

Weight of rail. per yard, in main road,

Weight of rail, per yard, in branch roads, (specify the different weight per yard,)

Maximum grade, with its length, in main road,

Maximum g ade, with its length, in branch roads,

Total rise and fall in misin road.

Total rise and fall in branch roilds,

Shortest radius of curvature, with length of curve, in main road,

Shortest radius of curvature, with length of curve, in branch roarls,

Total deurees of curvature, in main road.

Total degrees of curvature in bianch roads,

Total length of straight line, in main road,

Total l-ilgth of straight line, in branches,

Aggregatis length of wouden truss bridges,

Aggregate length of all other wooden bridges,

Aggregate length of iron bridges,

whole length of road unfenced on both sides,

Number of publlc ways crossed at grade.

Number of railroads crossed at grade,

Remarks,

Way stations for express trains,

Way stations for accommodation trains,

Flay stations,

Whole number of way stations,

Whole number of flag stations,

\section{DOINGS DURING THE YEAR.}

Miles run by passenger trains,

Miles run by freight trains,

Miles run by other trains,

Total miles run,

Number of passengers carried in the cars,

Number of passengers curried one mile.

Number of tons of merchantise carried in the cars,

Number of tons of merchandise carrited one mile.

Number of passengers carried one nile, to and from other roads,

Number of tons carried one mile, to and from other toads.

Ritte of speed adopted for express passenger trains, including stous.,

Avirage rate of speed actually attained by express passenger triins, including stops and detentions.

Rate of suerd adopted for acconmodation trains.

Rate of speed actually attained by accommodation trains, in. cluding stops and detentions.

Average, rate of speed actually attained by special trains, inclucling stops and detentious.

Averazo rate of speed adopted for freight trains, including stops.

Estim.ted weight in tons of passenger cars (not iucluding pas. se igers) hauled one mile,

Estimited weight in tons of merchandise cars (not including freight) hauled one mile,

16.882 miles.

16.882 miles.

None,

None.

1.734 miles.

$58 \mathrm{lbs}$.

None.

28.58 per mile 3380 feet.

None.

223.34

None.

1.200 feet for 1,425 feeth

None.

$395^{\circ}$

None.

13.368 miles.

None.

None.

121 reet.

None.

All fenced or otherwise prolected. 19

\section{None.}

4

4

nperated by the Boston \& Lowell Railroad Corporatjon, under contract. A copy is annezed to the report of 1858 . 


\section{EXPENDITURES FOR WORKING THE ROAD.}

For repairs of road, maintenance of way, exclusive of wooden bridges, and renewals $0^{\circ}$ iron,

For renairs of wooden bridges,

For wages of switchmen, average per month,

For wages of gate-keepers, average per month,

For wages of signal men, averago per month,

For wares of watchmen, average ner month.

Number of mell enuloyed, exclusive of those engaged in construction.

For removing ice and snow, (this item to include all labor, tools, repairs, and extra steam-power used,

For repairs of fences, gates, houses for signal-men, gate-keepers, switchmen, tool-houses,

Tutal for malntenunce of way,

\section{MOTIVE POWER AND CARS.}

For repairs of locomotives,

For neu lncomotives, to cover depreciation,

For repairs of passenger cars,

For new passenger cars, to cover depreciation,

For repairs of merchandise cars,

For new marchandise cars, to cover depreciation,

For repairs of gravel and other cars,

Thital for maintenance of motive power and cars,

Number of englnes,

Number of passenger cars,

Number of haggage cars,

Numlier of merchandise cars,

Number of gravel cars,

\section{MISCELLANEOUS.}

For fiel used by engines during the year, viz:-

Wood, number of cords. Cost oi the same,

Coal, number of tons, (reckoning 2,240 lbs, to the ton.) Cost of same.

For oil used by cars and engines,

For waste and otlier material for cleaning,

For salaries, wages, and incidental expenses, chargeable to passenger defartment.

For saluries, wages, and incidental expenses, chargeable to freight departinent.

For grutuitit+8 und damages,

For taxes and Insurance,

For ferries,

Fur repairs of station buildings, acqueducts, fixtures, furniture, For renewals of iron, including laying down,

For new Iron laid down, deducting the value of old iron taken np

For amount pain other companies in twills for passengers and freight carried on their roads, suecifyilng each company,

For amount paill other companies, as rent for use of their roads, spetifyilng each company,

For salisries of firesident, treasurer, superintendent, law expenses, offi:se expenses of the ahove offlces, ar:d all other exjenses 1100 included in any of the foregoing items, Tut:Il miscellaneous,

Total expenditures,

Total intount of interest paid during the year, (on funded dobt,)

Total expense and interest,

\section{INCOME DURING THE YEAR.}

For Pissengers :-

1. Oil main roal, including branches owned by company,

2. Th sulid from uther roads, specilying what,

For Froight:-

1. On unin road and branches owned by company,

2. 'I'o and from other connecting rouds,

U. S. Mails,

Rents

Othrr sources, 'lutal income,

Net earnings after deducting expenses,

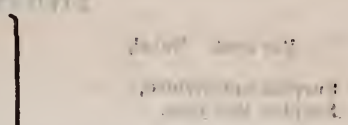

Paid by Boston \& Lowell Rallroad Corporation.

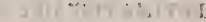

Run by Boston \& Lowell Rail road Corporation.

\section{:}

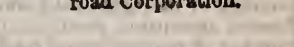

$\mathbf{3}$

197

None

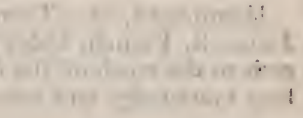

Operated by Boston \& Lowell Rallroad Cor poration.

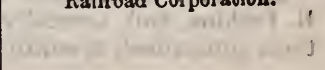

33006

30535

63541

13,32806

$\$ 13,96347$

Operated hy Boston and Lowell liailroad Corporation under crintract, who pay 17,50000 per aunum. 


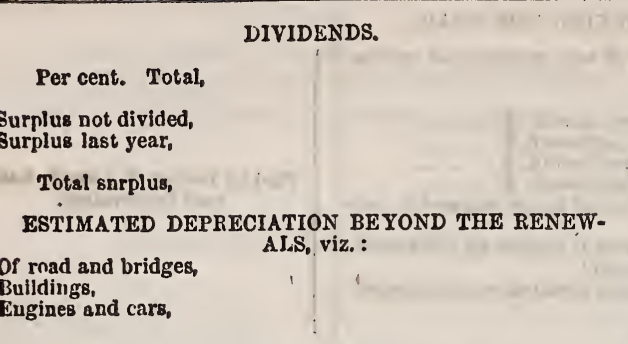

\section{MORTGAGE DEBTS.}

Amount of debts secured by mortgage of road and franchise, or any property of the corporation, per last report,

Mortgage debt jaid since last rẹport.

Increase of mortgage debt since last reporth

Present amount of mortgage debis,

Number of mortgages on ruad and franchise, or any property of the corporation,

Charles F. Frint,
Sidney Spaling,
Josiah B. French,
Caleb Livingston, $\quad\left\{\begin{array}{c}\text { Directors of the Salem } \\ \text { and Lowell Railroad } \\ \text { Company. }\end{array}\right.$

Lowelt, December 9, 1861.

Midncesex, ss.-Then personally appeared Charles F. Flint, Sidney Spalding, Josiah B. French, Caleb Livingston and Wm. E. Livingston, and severally made oath to the truth of the foregoing statement by them subscribed, according to their best knowledge and belief. Before

\section{F. H. NOUKSE. Justice of the Peace.}

Essex ss. December 10, 1861. - Then personally appeared J. W. Peele and N. B. Perkins, and severally made oath to the truth of the foregoing statement by them subscribed, according to their best knowledge and beliet: Before WM. H. FOS'L'ER, Justice of the Peace. 


\title{
THIRTEENT
}

\section{$A N N U A I \mathbb{R E O R T}$}

\author{
OF THE
}

SOUTH READING.BRANCH RAIL ROAD.

FOR THE YEAR ENDING

NOVEMBER 30, 1861 .

SA L E M :

WM. IVES AND GEO. W. PEASE, PRINTER,

1861 . 



\section{R E P O R T}

OF THE DIRECTORS OF THE

\section{SOUTH READING BRANCH RAILROAD CORPORATION,}

\section{For the Year Ending November 30, 1861.}

"To be returned to the Secretary of the Commonwealth, together with 1000 printed copies of the same, on or before the first Wednesday in January next.

[General Statutes, Chap. 63, Sections 132 to 135.

Capital Stock,
Number of shares of capital stock issued, :

Increase of Capital, since last Report, . . .

Capital paid in, per last Report, . . . .

Capital paid in, since last Report,

Total amount of capital stock paid in, : :

Funded debt, per last Report, . . . .

Funded debt, paid since last Report, : : .

Funded debt, increase of, since last Report, . .

Total present amount of funded debt, . . .

Floating debt, per last Report, . . . .

Floating debt, paid since last Report, . . .

Floating debt, increase of, since last Report, .

Total present amount of floating debt,

Total present amount of funded and floating debt,

Average rate of interest per annum, paid during the

Maximum amount of debts during the year, ·

Cost of Road and EQuipuent.

For graduation and masonry, per last Report,

For graduation and masonry, paid during the past year Total amount expended for graduation and masonry,

For wooden bridges, per last Report,

For wooden bridges, paid during the past year,

Total amount expended for wooden bridges, .

Total amount expended for iron bridges (if any)

For superstructure including iron, per last Report,

For superstructure, including iron, paid during the past year,

Total amount expended for superstructure, including iron,

For stations, buildings and fixtures, per last Report,

For stations, buildings and fixtures, paid during the past year,

Total amount expended for stations, buildings and fixtures,

Carried forward,
$\$ 400,00000$

$\$ 209,53273$

209,53273

103,93688

58573

103,93688

58573

61,53927

9,30303 
Brought forward,

For land, land damages and fences, per last $\dot{R}$ Report,

For land, land damages and fences, paid during the past year,

Total amount expended for land, land-damages and fences,

For locomotives, per last Report, • • • '

For locomotives, paid during the past year, .

Total amount expended for locomotives, .

For passenger and baggage cars, per last Report, .

For passenger \& baggage cars, paid during the past year

Total amount expended for passenger and baggage cars

For merchandise cars, per last Report,

For merchandise cars, paid duxing the past year

Total amount expended for merchandise cars,

For engineering, per last Report

For engineering, paid during the past year, .

Total amount expended for engineering,

For agencies and other expenses, per last Report,

For agencies and other expenses paid during the past year,

motal amount expended for agencies and other expenses

Total cost of road and equipment,

Amount of assets or property held by the corporation in addition to the cost of the road,

\section{Chatracteristícs of Road:}

Length of road,

Length of single main track ${ }^{\circ} \cdot{ }^{-}$

Length of double main track,

Length of branches owned by the Company stat-? Single

ing whether they have a single or double track. $\}$ track.

Aggregate length of sidings, and other tracks, excepting main tracks and branches,

Weight of rail, per yard, in main road,

Weight of rail, per yard, in branch roads. (specify the different weights per yard)

Maximum grade, with its length in main road, .

Maximum grade, with its length, in branch roads,

Total rise and fall in main road, .

Total rise and fall in branch roads.

Shortest radius of curvature, with length of curve, in. main road,

Shortest radius of curvature, with length of curve, in branch roads,

Total degrees of curvature, in main road,

Total degrees of curvature, in branch roads, .

Total length of straight line, in main road, . .

T'otal length of straight line in branches

Aggregate length of wooden truss bridges, .

Aggregate length of all other wooden bridges,

Aggregate length of iron bridges,

Whole length of road unfenced on both sides.

Number of public ways crossed at grade s $_{5}$.

Number of railroads crossed at grade, .

Remarks,

Way stations for express trains, . .

Way stations for accommodation trains,

Flag stations,

Whole number of way stations,

Whole number of flag stations,
8.15 Miles:

8.15 Miles.

1150 feet.

9345 feet.

$60 \mathrm{lbs}$.

$60 \mathrm{lbs}$.

Length $2200 \mathrm{ft}$. 52.8 feet.

237.6 feet.

566

40 G6

425 feet, length 290 feet.

350 feet, of 100 6s.

$232^{\circ} 15^{\prime}$

$80^{\circ} 41^{\prime}$

6.85 Miles.

578 feet.

326 c 
Dorngs During the Year.

\begin{tabular}{llll|l} 
Miles run by passenger trains, & - & - & - & 25,040 \\
Miles run by freight trains, & - & - & - &
\end{tabular}

Miles run by other trains, - - .

Total miles run, - - - -

Number of passengers carried in the cars, -

Number of passengers carried one mile, - -

Number of tons of merchandise carried in the cars,

Number of tons of merchandise carried one mile,

Number of passengers carried one mile, to and from other roads,

Number of tons carried one mile, to and from other roads,

Rate of speed adopted for express passenger trains, including stops

Average rate of speed actually attained by express passenger trains, including stops and detentions,

Rate of speed adopted for accommodation trains,

Rate of speed actually attained by accommodation trains, including stops and detentions,

Average rate of speed actually attained by special trains, including stops and detentions,

Average rate of speed adopted for freight trains, including stops,

Estimated weight in tons of passenger cars (not including passengers) hauled one mile, - -

Estimated weight in tons of merchandise cars (not including freight) hauled one mile, -

54,254

348,261

5,302

29,124

225,451

7,779

21 Miles per hour.

20 66 66 66

$21 \quad 66 \quad 56 \quad 66$

20

20

62,705

24,270

\section{Expenditures for Working the Road.}

For repairs of road, maintenance of way, exclusive of wooden bridges, and renewals of iron,

For repairs of wooden bridges, -

For wages of switchmen, av per month,

For wages of signal-men, av. per month,

For wages of watchmen, av. per month,

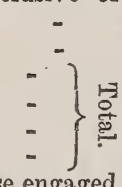

Number of men employed, exclusive of those engaged in construction,

$-$

For removing ice and snow, (this item to include all labor, tools, repairs, and extra steam-power used,)

For repairs of fences, gates, houses for signal-men, gate-keepers, switchmen, tool-houses,

Total for maintenance of way,

-

2,48036

14

\section{Motive Power and Carg.}

For repairs of locomotives,

For new locomotives, to cover depreciation,

For repairs of passenger cars, - -

For new passenger cars, to cover depreciation, -

For repairs of merchandise cars, and other cars, -

For new merchandise cars, to cover depreciation,

For repairs of gravel and other cars,

Total for maintenance of motive power and cars,

Number of engines,

Number of passenger cars,

Number of baggage cars, -

Number of merchandise cars,

\begin{tabular}{|c|c|c|}
\hline ه & . & Coris \\
\hline 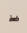 & - & - \\
\hline & - & $=$ \\
\hline & - & \\
\hline & 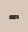 & $=$ \\
\hline
\end{tabular}

Number of gravel cars, 


\section{Miscellaneous.}

For fuel used by engines during the year, viz.:-

1. Wood, number of cords, 357. Cost of the same,

2. Coal, number of tons, (reckoning $2,240 \mathrm{Ibs}$. to the ton,) 153. Cost of the same,

For oil used by cars and engines, gallons, 399, -

For waste and other material for cleaning,

For salaries, wages and incidental expenses, chargeable to passenger department,

For salaries, wages, and incidental expenses, chargeable to freight department, - - -

$\begin{array}{lll}\text { For gratuities and damages, } & - & -\end{array}$

$\begin{array}{lllll}\text { For taxes - } & - & - & - & -\end{array}$ -

For repairs of station buildings, aqueducts, fixtures, furniture, and other station expenses,

For renewals of iron, including laying down,

For new iron laid down, deducting the value of old iron taken up,

For amount paid other companies, in tolls for passengers and freight carried on their roads, specifying each company,

For amount paid other companies, as rent for use of their roads, specifying each company, (Essex Rail Road.)

For office expenses,

Total Miscellaneous,

Total expenditures for working the road,

Total amount of interest paid during the year.

\section{Inconte During the Year.}

\section{For Passengers :-}

1. On main road, including branches owned by company,

2. To and from other roads, specifying what, (Boston and Maine R. R.)

For Freight:-

1. On main road and branches owned \begin{tabular}{lr} 
by company, - $\quad-$ & 1,28061 \\
\hline
\end{tabular}

2. To and from other connecting roads.

U. S. Mails,

Rents and Miscellaneous,

Total income,

Loss,

Note. This Report is incomplete, because of the omission of the Boston and Maine Rail Road to make the necessary returns of joint business.

\section{Dividends.}

Per cent. Total, -

Surplus not divided,

Surplus last year -

Total surplus,
1,782 77

88645

37042

5,27295

2470

1,39722

3,20000
1800

$\$ 12,95251$

18,53847

$14,690 \quad 54$

1,73105

33527 
Estrmated Depreciation Beyond the Renewals, viz.

$\left.\begin{array}{lllll}\text { Of road and bridges, } & - & - & - & - \\ \text { Buildings, - } & - & - & - & - \\ \text { Engines and cars, } & - & - & - & -\end{array}\right\}$ Nothing.

\section{Mortgage Debts.}

Amount of debts secured by mortgage of road and franchise, or any property of the Corporation, per last Report,

Mortgage debt paid since last Report,

Increase of mortgage debt since last Report, -

Present amount of mortgage debts,

Number of mortgages on road and franchise, or any

property of the corporation, -

$\left.\begin{array}{l}\text { GEORGE M. BROWNE, } \\ \text { MICAJAH LUNT, } \\ \text { W. L. DWIGHT, } \\ \text { NATHAN D. CHASE, } \\ \text { HENRY L. WILLIAMS, }\end{array}\right\} \begin{gathered}\text { Directors } \\ \text { of the } \\ \text { South Reading } \\ \text { Corporation. }\end{gathered}$

Sufrolk, ss. December 19, 1861. Then personally appeared George M. Browne, Micajah Lunt, W. L. Dwight, Nathan D. Chase, and Henry L. Williams, and severally made oath to the truth of the foregoing statement by them subscribed, according to their best knowledge and belief, before me,

JOHN B. PARKER, Justice of the Peace.

\section{A C C I DE N T}

1860.

December 29th, W. H. Browne in attempting to cross the track near South Reading, was struck by the passenger train, and so much injured that he died the next day. 



\title{
T H I R D
}

\section{ANNUAL REPORT}

\author{
O F. TH E
}

\section{SOMERVILLE HORSE RAILROAD}

T O T H E

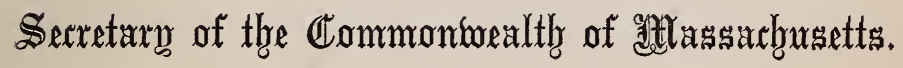

FOR THE YEAR ENDING NOVEMBER 30th, 1861.

CHARLESTOWN :

PRINTED BY W. W. WHEILDON.

1861 . 


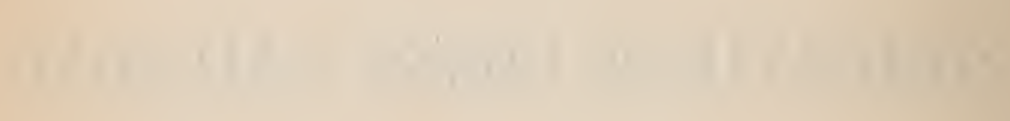


OF THE

\section{SOMERVILLE HORSE RAILROAD CORPORATION.}

For the Year ending November 30 th, 1861 .

Report of the Somerville Horse Railroad Corporation under General Statutes, Chapter 60. Sects. 143, 144.

Condition of the Company.

Capital stock, fixed by charter,

Capital stock, as voted by the company,

Capital stock paid in, in cash,

Capital stock paid in, in work and materials, by contractors and others,

Funded debt,

Floating debt, - $\quad-\quad[\quad-\quad-\quad-\quad-$

Total debt, - - - - -

Amount of above debt secured by mortgage of the road and franchise, or any property belonging to the corporation, or standing in its name,

Number of mortgages on road and franchise, or any property of the corporation, specifying the number and amount of mortgages on road and franchise, and each kind of property,

Amount of assets on hand, exclusive of the road and equipment, and exclusive of all property on hand, used, or which is to be used, in running the road and keeping it in repair,

Cost of the Road.

Amount expended for labor in excavating for the track, laying foundations and rails,

Amount expended in timber for foundation, -

Amount expended for iron and other metal for rails, chairs, spikes, or other articles, used in building the road,

Amount expended for paving, - - -

Amount expended for paving stones, - -

Amount expended for engineering, - -

Amount expended for interest, salaries of officers during construction of road, and other expenses not included in any of the above items, which have been included, on the books of the company, in the cost of the road, not including items of equipment or running expenses, as mentioned below,

Total cost of road,

Amount included in the present and in past years, among the running expenses for estimated or actual depreciation of the road, -

Net cost of road,

$\$ 50,000 \quad 00$

$\$ 100,000 \quad 00$

$\$ 50,000 \quad 00$

None.

None.

None.

Built by contract. 


\section{Cost of Equipment.}

Number of cars and cost, -

Number of horses and cost,

Cost of omnibuses, sleighs and other vehicles, excepting cars, owned by the company, -

Cost of land and buildings thereon when purchased,

Cost of buildings used for offices, stables, \&c., erected by the company, or standing on land not owned by the company,

Cost of other articles of equipment, (specifying what,)

Total cost of equipment, - - - -

Amount included in the present and in past years in the running expenses for estimated or actual depreciation of any of the above items,

Net amount at which the equipment stands charged on the books of the company,

\section{Characteristics of the Road.}

Length of single main track,

Length of double main track,

Length of branches owned by the company, stating whether they have a single or double track,

Aggregate length of switches, sidings, turnouts and other track, excepting main track and branches,

Total length of rail,

Weight of rail used, per yard, (specifying whether of cast or rolled iron,)

Maximum grade, per mile on road, with length of grade,

Shortest radius of curvature, with length of curve,

Greatest length of single track on road between two turnouts,

Total length of main track which is paved, -

\section{Doings during the Year.}

Total number of miles run during the year, -

Number of passengers carried in the cars, -

Rate of speed adopted, including stops and detentions,

Rate of speed actually attained, including stops and detentions,

Number of persons employed, regularly, (specifying the occupations of each,)

Total number of trips run during the year, -

Average number of passengers each trip,
This Road is under lease to the Malden and Melrose Railroad Co., who furnish the entire equipment.

14,130 feet.

14,130 “

598 “

29,456 “

28 lbs. Rolled.

Nominal.

188 feet in 75 feet.

7,554 “

Road under lease, as previously stated. 
Expenditures for Working the Road.

For repairs of road, including repairs of foundation, renewals of iron, and renewals of pavement,

For general repairs, including repairs of cars, omnibuses and harnesses, and for shoeing horses,

For repairs of real estate, including repairs of buildings used as stables, offices, or for any other purposes, by the company,

For wages, including the wages of every person regularly employed, excepting the president, directors, superintendent and treasurer,

For interest,

For taxes and insurance, - - - -

For tolls paid other companies for the right to pass over their roads,

For rent paid other companies for use of their roads,

For provender, - to include cost of hay, grain, straw, or other articles used for the food or bedding of horses,

For miscellaneous articles purchased during the year - such as harnesses, blankets, \&c., the use of which continues for one or more years - and not included in the cost of equipment,

For loss on horses - that is to say, the difference between the present estimated value of the horses owned by the company subtracted from the estimated value of those on hand at the commencement of the year, added to the cost of those purchased during the year; or if this is the first report of the company, then the difference between the estimated value of the horses on hand and their cost - giving the present av. estimated value of each horse,

For incidental expenses, - to include printing, president's, directors', treasurer's and superintendent's salaries, and all expenses other than those belonging to the actual working of the road,

For all other expenses,

For amount charged on the company's books during the year, for estimated or actual depreciation of the following property:-

Cars,

Omnibuses, - - $\quad-\quad-\quad-\quad$

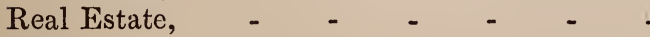

Road, - $\quad$ - $\quad$ - $\quad$ - $\quad$ -

Other property, - $\quad$ - $\quad$ - $\quad$ -

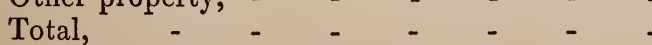

Total expenses, - $\quad$ - $\quad$ - $\quad$ -
Road under lease, as previously stated. 


\section{Earinings.}

Received from passengers in cars and omnibuses, and for tickets sold,

From other roads, as toll or rent for use of road, From United States mails, - $\quad$ - $\quad$ For sales of manure, - $\quad$ - $\quad$ - $\quad$ -

From other sources, - $\quad$ - $\quad$ - $\quad$ -

Total earnings, - $\quad-\quad$ - $\quad$ - $\quad$ -

Net earnings, after deducting expenses, -

Surplus earnings of previous year, on hand, -

Net earnings, as above,

'Total surplus for payment of dividends, -

Dividends declared, during the year, - -

Total per centage of dividends, for the year, -

Present surplus,

\section{Miscellaneous.}

\section{Increase during the year -}

Of capital stock, as fixed by the charter, -

Of capital stock, as roted by the company, Of capital stock, paid in,

Increase of funded debt, during the year, Increase of floating debt, during the year, Decrease of funded debt, during the year, Decrease of floating debt, during the year, Increase of mortgage debt, during the year, Decrease of mortgage debt, during the year, Increase in cost of road, during the year, including amount charged for depreciation thereon,

Decrease in nominal cost of road, by amount charged for depreciation thereon,

Increase in cost of equipment, during the year, including amount charged for depreciation thereon,

Decrease in cost of equipment, by sale of any portion thereof, or by amount charged for depreciation,

List of accidents on road during the year, -
Received rent from May 1st, 1861, to November 1st, 1861, $\$ 1250$, which was distributed in one dividend of $2 \frac{1}{2}$ per cent. on $\$ 50,000$ stock.

Leased as previously stated.

GEO. A. WHITING.

CHAS. E. POWERS. 


\section{COMMONWEALTH OF MASSACHUSETTS.}

Middlesex, ss.

Boston, December 30, 1861.

Personally appeared the above named Geo. A. Whiting, Chas. E. Powers, and Enoch Robinson, Directors of the Somerville Horse Railroad Company, and made oath that the foregoing statement by them subscribed, is true, according to their best knowledge and belief.

Before me,

L. M. CHILDS, Justice of the Peace. 

SIXTEENTH ANNUAL REPORT

OF THE

\section{South SHore TAIL TOAD Company,}

\section{Being for the Year cnding Norember 30, 1861.}

To be returned to the Secretary of the Commonwealth, together with 1000 printed copies of the same, on or before the first Wednesday in January next.

General Statutes, Chap. 63, Sections 132 to 135.

Capital Stock,

Number of shares of capital stock issued, Increase of capital, since last Report, Capital paid in, per last Report, - Capital paid in, since last Report,

Total amount of capital stock paid in, Funded debt, per last Report, Funded debt, paid since last Report, Funded debt, increase of, since last Report, Total present amount of funded debt, Floating debt, per last Report, Floating debt, paid since last Report, Floating debt, increase of, since last Report, Total present amount of floating debt, Total present amount of funded and floating debt,

Average rate of interest per annum, paid during the year,

Maximum amount of debts during the year,

Cost of Road and Equipment.

For graduation and masonry, per last Report, For graduation and masonry, paid during the past year,

Total amount expended for graduation and masonry

\author{
$\$ 600,000$ \\ 10,000 \\ none \\ 259,685 \\ 259,685 \\ 150,000 \\ 2,39143 \\ 150,000
}

37729

2,76872

152,76872

6 per cent.

125,38206 
For wooden bridges, per last Report, -

13,44850

For wooden bridges, paid during the past yr.

Total am't expended for wooden bridges

Total amount expended for iron bridges

For superstructure, including iron, per last Report

For superstructure, including iron, paid during the last year,

Total amount expended for superstructure, including iron,

For stations, buildings and fixtures, per last Report,

For stations, buildings and fixtures, paid during the past year,

Total am't expended for stations, buildings and fixtures,

For land, land-damages, and fences, per last Report,

For land, land-damages and fences, paid during the past year,

Total amount expended for land, landdamages and fences, - - -

For locomotives, per last Report, - -

For locomotives, paid during the past year,

Total amount expended for locomotives,

For passenger and baggage cars, per last Report,

For passenger and baggage cars, paid during the past year,

Total amount expended for passenger and baggage cars, - -

For merchandise cars, per last Report,

For merchandise cars, paid during the past year,

Total amount expended for merchandise cars, -

For engineering, per last Report, - -

For engineering, paid during the past year,

Total amount expended for engineering,

For agencies and other expenses, per last Report,

For agencies and other expenses, paid during the past year,

Total amount expended for agencies and other expenses, - - -

Total cost of road and equipment,

Amount of assets or property held by the corporation, in addition to the cost of the road, 


\section{Characteristics of Road.}

Length of road,

Length of single main track, - -

Length of double main track, - -

Length of branches owned by the Company, stating whether they have a single or double track,

A ggregate length of sidings \& other tracks, excepting main tracks and branches,

Weight of rail, per yard, in main road,

Weight of rail, per yard, in branch roads (specify the different weights per yard),

Maximum grade, with its length, in main road,

Maximum grade, with its length, in branch roads,

Total rise and fall in main road, - -

Total rise and fall in branch roads, -

Shortest radius of curvature, with length of curve, in main road,

Shortest radius of curvature, with length of curve, in branch roads,

Total degrees of curvature, in main road, Total degrees of curvature, in branch roads, Total length of straight line, in main road, Total length of straight line, in branches, Aggregate length of wooden truss bridges, Aggregate length of all other wooden bridges, - - - - - -

Aggregate length of iron bridges,

Whole length of road unfenced on both sides,

Number of public ways crossed at grade,

Number of railroads crossed at grade,

Remarks,

Way stations, for express trains, - -

Way stations, for accommodation trains,

Flag stations,

Whole number of Way stations, -

Whole number of flag stations, - -

\section{Doings DURING the Year.}

Miles run by passenger trains (in addition our cars have run 19,860 miles over the O. C. \& F. R. R. R.)

Miles run by freight trains, (incl. in pass. tr.) Miles run by other trains,
115 miles.

11.5 '

2100 feet.

$52 \mathrm{lbs}$.

$34, \frac{85}{1 \cup 0} \mathrm{ft}$. for $3 \frac{1}{2}$ miles.

$259_{10}^{4} \mathrm{ft}$.

$\left\{477 \frac{1}{2} \mathrm{ft}\right.$. for $697 \frac{1}{2} \mathrm{ft}$. at junct. O.C. \& F.R.R.R.

$704^{\circ} 42^{\prime}$

$7 \frac{8}{10}$ miles.

50 feet.

1000 feet.

$\frac{1}{8}$ mile.

26

8

2

8

2

22,988 Total miles run, 
Number of passengers carried in the cars,

Number of passengers carried one mile,

Number of tons merch'dise carried in cars,

Number of tons of merchandise carried $1 \mathrm{~m}$.

Number of passengers carried one mile, to and from other roads,

Number of tons carried one mile, to and from other roads,

Rate of speed adopted for express passenger trains, including stops,

Average rate of speed actually attained by express passenger trains, including stops and detentions,

Rate of speed adopted for accom. trains,

Rate of speed actually attained by accom. trains, including stops and detentions,

Average rate of speed actually attained by special trains, incl. stops and detentions,

Average rate of speed adopted for freight trains, including stops and detentions,

Estimated weight in tons of passenger cars (not including passengers), hauled 1 mile,

Estimated weight in tons of merchandise cars (not including freight), hauled $1 \mathrm{~m}$.

\section{Expenditures for Working the Road.}

For repairs of road, maintenance of way exclusive of wooden bridges, and renewals of iron,

For repairs of wooden bridges,

For wages of switchmen, average per month, - - - -

For wages of gate-keepers, average per month

For wages of signal-men, average per month,

For wages of watchmen, average per month,

Number of men employed, exclusive of those engaged in construction,

For removing ice and snow (this item to include all labor, tools, repairs, and extra steam power used), -

For repairs of fences, gates, houses for signal-men, gate-keepers, switchmen, toolhouses,

Total for maintenance of way, - .
96,784

527,536

1,500

14,365

462,787

14,200

$22 \mathrm{~m}$. per hour.

$22 \mathrm{~m}$. " "

51,422

9,449

4,16772

705

32

12013 


\section{Motive Power and Cars.}

For repairs of locomotives (work done in our own shop), -

For new locomotives, to cover depreciation, For repair's of passenger cars,

For new pass. cars to cover depreciation, For repairs of merchandise cars, -

For new merchandise cars, to cover depreciation,

For repairs of gravel and other cars, -

Total for maintenance of motive power and cars,

Number of engines, - - -

Number of passenger cars, - - -

Number of baggage cars, - - -

Number of merchandise cars, - -

Number of gravel cars, - - -

\section{Miscellaneous.}

For fuel used by engines during the year, viz.-Wood, number of cords,

Cost of the same,

Coal, number of tons (reck'g $2,240 \mathrm{lbs}$. to the ton), - -

Cost of the same, - - -

For oil, used by cars and engines, -

For waste and other material for cleaning;

For salaries, wages and incidental expenses, chargeable to passenger department,

For salaries, wages and incidental expenses, chargeable to freight department,

For gratuities and damages,

For taxes and insurance,

For ferries, - - - _ -

For repairs of station buildings, aqueducts, fixtures, furniture,

For renewals of iron, including laying down, For new iron laid down, deducting the value of old iron taken up,

For amount paid other companies, in tolls for passengers and freight carried on their roads, specifying each company (Old C. and F. River R.R.)
1,49418

$955 \imath 9$

8416

2,53413

2

7

2

8

7

2,79817

29995

5075

8,56116

24611

9631 
For amount paid other companies, as rent for use of their roads, specifying each company, -

For salaries of president, treasurer, superintendent, law expenses, office expenses of the above offices, and all other expenses not included in any of the foregoing items,

Total miscellaneous,

Total expenditures for working the South Shore Railroad, - 20,65943 For amount paid O. C. \& F. R.

R. R., as above stated, - $\quad 17,91794$ Total expenditures for working the road, Total amount of interest paid during the year,

For amount paid to the sinking fund, -

InCOME DURING the Year.

For Passengers :-

1. On main road, including branches owned by company,

2. To and from other roads, specifying what-(0. C. \& F. R. R. R.) -

1,08000

13,13245

38,57737

8,53744

2,00000

26,81755

16,51049

For Freight:-

1. On main road and branches owned by company, - - - - -

2. To and from other connecting roads,

U. S. Mails, -

Rents and interest, - $\quad$ - $\quad$ -

Total income, - - - - -

Net earnings, after deducting expenses,

\section{Divinends.}

per cent. Total, -

Surplus not divided, -

Surplus last year,

Surplus last year, - - - - - $\quad 52,94184$

Total surplus, $(\$ 38,70000$ is merged in the new issue of bonds due 1880), -

3,41149

1,40745

90000

1,10850

50,15548

11,57811

Estimated Depreciation beyond the RENEWALS, viz. :

Roads and bridges,

Building,

Engines and cars, 


\section{Mortgage Debts.}

Amount of debts, secured by mortgage of road and franchise, or any property of the Corporation, per last Report,

150,00000 Mortgage debt, paid since last Report, Mortgage debt, increase of, since last Rep't, Total present amount of mortgage debt, Number of mortgages on road and franchise, or any property of the Corporation, 150,00000

Two. $\left.\begin{array}{l}\text { WM. HUMPHREY, } \\ \text { ELLIOT L. WHITE, } \\ \text { CHARLES HUMPHREY, } \\ \text { JOSEPH LOUD, JR. } \\ \text { MINOT TIRRELL, }\end{array}\right\}$ Directors.

Surrolk, ss. Jan. 1, 1862. Then personally appeared the said Wm. Humphrey, Elliot L. White, Charles Humphrey, Joseph Loud, Jr., and Minot 'Tirrell, and severally made oath to the truth of the foregoing statement, by them subscribed, according to the best of their knowledge and belief.

Before

Јонn G. KIng, Justice of the Peace. 

A IV IV UAI IRIPOIF

$$
\text { OF THE }
$$

\title{
STOCKBRIDGE AND PITTSEIELD
}

\author{
RAIL-R 0 A D C 0 M PAN $\mathrm{Y}$,
}

\author{
FOR 1861.
}


IEIOIT

OF T H E

\section{STOCKBRIDGE AND PITTSFIELD RAILROAD.}

Report of the Directors of the Stockbridge and Pittsfitd Railroud Corporation, for the year ending November $30,1861$.

Capital Stock, -

Capital Stock, - $\quad$ - $\quad$ - $\quad$ - $\quad$ - $\quad$ - $\quad$ - $\$ 448,700$

Number of shares of capital stock issued, - - $\quad 4,487$

Capital paid in, per last Report, - _ - - $\quad$ - 448,700

Total amount of capital stock paid in, . - $\quad . \quad 448,760$

\section{Cost of Road and Equiruent.}

For graduation and masonry, per last Report, _ - $\$ 154,263$

Total amount expended for graduation and ma-

- A. sonry, - - - - -

Total amount expended for wooden bridges, - $\quad 8,489$

For superstructure, including iron, per last Keport, - 163,413

'Total amount expended for superstructure, including iron,

For stations, buildings and fixtures, per last Réport,

Total amount expended for stations, buildings and fixtures,

163,413

30,700

30,700

70,000

Total amount expended for land, land-damages and fences,

70,000

4,100

4,100

8,000

8,000

9,735

For agencies and other expenses, per last Report, -

Total amount expended for agencies and other

expenses, - - - - - - -

Total cost of road and equipment, - - -
Amount of assets or property held by the corpora-

tion in addition to the cost of the road,

9,735

448,700

25 shares of its stock. 


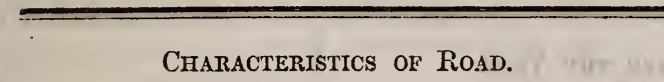

Characteristics of Road.

Length of road, - $\quad$ - $\quad$ -

Length of single main track, - $-{ }_{-}-{ }_{-}-$

Aggregate length of sidings, and other tracks, excepting main track and branches, - - -

Weight of rail, pel yard, in main road, - - -

Maximum grade, with its length, in main road, -

Total rise and fall in main road, - - - -

Shortest radius of curvature, with length of curve, in main road,

Total degrees of currature, in main road,

Total length of straight line, in main road, - -

Aggregate length of wooden truss bridges, - -

Agrregate length of all other wooden bridges, -

Number of public ways crossed at grade, - -

Way stations for accommodation trains, - - -

Flag stations, - $\quad$ - $\quad$ - $\quad$ -

Whole number of way stations, _. _ _ _ _

Whole number of flag stations, $-1-c_{-}$

\section{Doivgs During the Year.}

Rate of speed adopter for accommodation trains, -

Rate of speed actually attained by accommodation trains, including stops and detentions, - - -

Arerage rate of speed adopted for freight trains, including stops,

\section{EXPENDITURES FOR WORKIYG THE ROAD.}

Leased to Housatonic Railroad Co., they keeping all accounts and paying all expenses.

Motive Power and Cars.
21 93-100 miles. 21 93-100 miles.

\section{5,700 feet.}

54 lbs., 56 lbs., 60 lhs. $42 \mathrm{ft}$. length $92-100 \mathrm{mls}$ Rise $262 \mathrm{ft}$, fall $93 \mathrm{ft}$.

$515 \mathrm{ft}$., length $858 \mathrm{ft}$.

$2011^{\circ}$

11 46-100 miles.

932 feet.

20 feet.

21

9

1

9 : : Finat t)

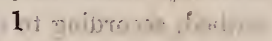

25 miles per hour.

20 miles per hour.

7 miles per hour. 
4 REPORT OF STOCKBRIDGE AND PITTSFIELD RALLROAD CO.

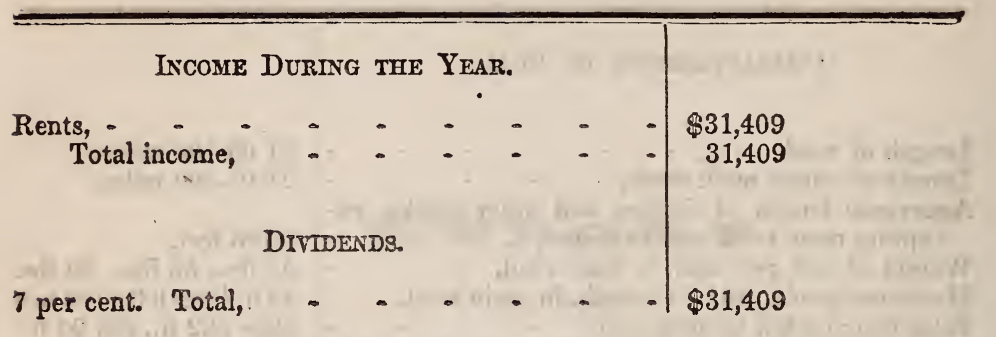

\section{DANIEL R. WILLIAMS, Directors of the WILLIAM WHITNEY, Stockbridge and Pittsfield W. B. COOLEY, Railroad Corporation.}

BerKsIIRE ss. December 9, 1861. Then personally appeared Daniel $R$. Williams, William Whitney, Edward H. Owen, and William B. Cooley, and severally made oath to the truth of the foregoing statement by them subscribed, according to their best knowledge and belief. Before

J. Z. Goodricr, Justice of the Peace. 


\section{REPORT OF THE DIRECTORS}

OF THE

\section{STONEHAMI BRANCH R. R. CORPORATION.}

For the year ending November 30, 1861. General Slatutes, Chap. 63, Scets. 132-135.

1. Capital stock,

2. Number of shares of capital stock issued, .

3. Increase of capital, since last report, . .

5. Capital paid in, since last report, .

6. Total amount of capital stock paid in, .

7. Funded debt, per last report,

8. Funded debt, paid since last report,

9. Funded debt, increase of, since last report,

10. Total present amount of funded debt, .

11. Floating debt, per last report,

12. Floating debt, paid since last report, .

13. Floating debt, increase of, since last report,

14. Total present amount of floating debt, .

15. Total present amount of funded and floating

16. Average rate of interest per annum, paid during the year,

17. Maximum amount of debts during the year,

\section{Cost of Road and Equipment.}

18. For graduation and masonry, per last report,

19. For graduation and masonry, paid during the past

20. Year, $\quad$ Total amount expended for graduation and masonry,

21. For wooden bridges, per last report,

22. For wooden bridges, paid during the past year,

23. Total amount expended for wooden bridges,

24. Total amount expended for iron bridges (if any),

25. For superstructure, including iron, per last report,

26. For superstructure, including iron, paid during

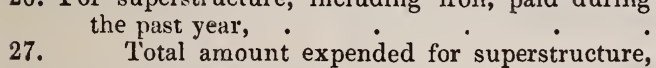
including iron,

28. For stations, buildings and fixtures, per last report,

29. For stations, buildings and fixtures, paid during

30. the past year, Total amount expended for stations, buildings and fixtures, .

31. For land, land-damages and fences, per last report,

32. For land, land-damages and fences, paid during the past year,

33. Total amount expended for land, land-damages and tences,

34. For locomotives, per last report

35. For locomotives. paid during the past year,

36. Total amount expended for locomotives,

37. For passenger and haggage cars, per last report,

38. For passenger and baggage cars, paid during the

39. Total amount expended for passenger and
$\$ 16,50000$

15,00000 
40. For merchandise cars, per last report,

41. For merchandise cars, paid during the past year, :

42. Total amount expended for merchandise cars,

43. For engineering, per last report

44. For engineering, paid during the past year, :

45. Total amount expended for engineering, .

46. Frr agencies and other expenses, per last report, .

47. For agencies and other expenses, paid during the past year,

48. Tutal amount expended for agencies and other expenses, . . . .

49. Total cost of road and equipment, :

50. Amount of assets or property held by the corporation in addition to the cost of the road, .

Characteristics of Road.

51. Length of road,

52. Length of single main track,

53. Length of double main track,

54. Lergth of branches owned by the Company, stating whether they have a single or double track,

55. Aggregate length of sidings, and other tracks, excepting maiu track and branches,

56. Weight of rail, per yard, in main road,

57. Weight of rail, per yard, in branch roads, (specify the different weights per yard, )

58. Maximum grade, with its length, in main road, .

59. Maximum grade, with its length, in branch roads,

60 . Total rise and fall in main road,

61. Total rise and fall in branch roads,

62. Shortest radins of curvature, with length of curve, in main road,

63. Shortest rodius of curvature, with length of curve, in branch roards,

64. Total degrees of curvature, in main road,

65. Total degrees of curvature, in branch roads,

66. Total length of straight line, in main road,

67. Total length of straight line, in branches,

68. Aggregate length of wooden truss bridges,

69. Aggregate length of all other wooden bridges,

70. Aggregate length of iron bridges, .

71. Whole length of road unfenced on both sides,

72. Number of public ways crossed at grade, .

73. Number of railroads crossed at grade, .

74. Remarks, .

75. Way stations for express trains,

76. Way stations for accommodation trains, .

77. Flag stations,

78. Whole number of way stations,

79. Whole number of flag stations, :

\section{Doings During the Year.}

80. Miles run by passenger trains,

81. Miles run by freight trains,

82. Miles run by other trains, .

83.

Total miles run,

$50 \mathrm{lbs}$.

75 feet.

84. Number of passengers carried in the cars, .

85. Number of passengers carried one mile, .

86. Number of tons of merchandise carried in the cars,

87. Number of tons of merchandise carried one mile,

88. Number of passengers carried one mile, to and from other roads,

89. Number of tons carried one mile, to and from other roads,

90. Rate of speed adopted for express passenger trains, including stops, . 
91. Average rate of speed actually attained by express passenger trains, including stops and detentions,

92. Rate of speed adopted for accommodation trains, .

93. Rate of speed actually attained by accommodation trains, including stops and detentions, .

94. Average rate of speed actually attained by special trains, including stops and detentions, .

95. A verage rate of speed adopted for freight trains, including stops,

96. Estimated weight in tons of passenger cars, (not including passengers,) hauled one mile,

97. Estimated weight in tons of merchandise cars, (not including freight,) hauled one mile,

Expenditures for Woriking the Road.

98. For repairs of road, maintenance of way, exclusive of wooden bridges, and renewals of iron, .

99. For repairs of wooden bridges,

100. For wages of switchmen, average per month, .

101. For wages of gate-keepers, average per month, .

102. For wages of signal-men, average per month, .

103. For wages of watchmen, average per month, .

104. Number of men employed, exclusive of those engaged in construction,

105. For removing ice and snow, (this item to include all labor, tools, repairs, and extra steam-power used,) .

106. For repairs of fences, gates, houses for signal-men, gate-keepers, switchmen, tool-houses,
Total for maintenance of way,

Motive Power and Cars.

108. For repairs of locomotives,

109. For new locomotives, to cover depreciation,

110. For repairs of passenger cars,

111. For new passenger cars, to cover depreciation, :

112. For repairs of merchandise cars, .

113. For new merchandise cars, to cover depreciation,

114. For repairs of gravel and other cars,

115. Total for maintenance of motive power and cars,

116. Number of engines,

118. Number of passenger cars,

119. Number of merchandise cars, .

120. Number of gravel cars, .

\section{Miscellaneous.}

121. For fuel used by engines during the year, viz. :-

1. Wood, number of cords, . Cost of the

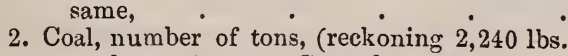
to the ton,) . Cost of same,

122. For oil used by cars and engines,

123. For waste and other material for cleaning

124. For salaries, wages and incidental expenses, chargeable to passenger department,

125. For salaries, wages and incidental expenses, chargeable to freight department,

126. For gratuities and damages,

127. For taxes and insurance, .

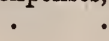


128. For ferries,

129. For repairs of station buildings, aqueducts, fixtures, furniture,

130. For renewals of iron, including laying down, :

131. For new iron laid down, deducting the value of old iron taken up,

132. For amount paid other companies, in tolls for passengers and freight carried on their.roads, specifying each company,

133. For amount paid other companies, as rent for use of their roads, specifying each company, .

134. For salaries of president, treasurer, superintendent, law expenses, office expenses of the above offices, and all other expenses not included in any of the foregoing items,

135.

Total miscellaneous, .

136. Total expenditures for working the road,

137. Total amount of interest paid during the year, .

INCOME DURING The YeAR.

138. For Passengers:-

1. On main road, including branches owned by company,

2. To and from other roads, specifying what,

139. For Freight:-

1. On main road and branches owned by company,

2. To and from other connecting roads,

140. U. S. Mails,

141. Rents,

142. Total income,

143. Net earnings, after deducting ‘xpenses,

\section{Dividends.}

144. Per cent. Total, .

145. Surplus not divided,

146. Surplus last year,

147. Total surplus,

Estimated Depreciation beyond the Renewals, Viz.:-

148. Of road and bridges,

149. Buildings,

150. Engines and cars,

Mortgage Debts.

151. Amount of debts, secured by mortgage of road and franchise, or any property of the corporation, per last report,

152. Mortgage debt, paid since last report

153. Increase of mortgage debt, since last report,

154. Present amount of mortgage debts,

155. Number of mortgages on road and franchise, or any property of the corporation,

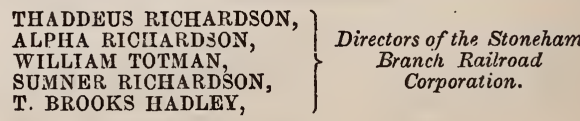

MrDDleSEx, ss., December 31, 1861. Then personally appeared Thaddeus Richardson, Alpha Richardison, Sumner Richardson, T. Brooks Hadley, William Totman, and severally made oath to the truth of the foregoing statement, by them subscribed. 


\title{
REPORT OF THE DIRE(TORS
}

\author{
OF THE
}

\section{Stony Brook Railroad Corporation,}

\section{FOR THE YEAR ENDING NOVEMBER 30, 1861.}

\section{Capital Stock,}

Number of shares of capital stock issued, Increase of capital since last report,

Capital paid in, per last report,

Capital paid in, since last report,

Total amount of capital stock paid in,

Funded debt, per last report,

Funded debt, paid since last report.

Funded debt, increase of, since last report, Total present amount of funded debt,

Floating debt, per last report,

Floating debt, paid since last report,

Floating debt, increase of, since last report,

Total present amount of floating debt,

Total present amount of funded and floating debt,

Average rate of interest per annum, paid during the year, Maximum amount of debts during the year,

\section{COST OF ROAD AND EQUIPMENT.}

For graduation and masonry, per last report,

For graduation and masonry, paid during the past year,

Total amount expended for graduation and masonry,

For wooden bridges, per last report,

For wooden bridges, paid during the past year,

Total amount expended for wooden bridges,

Total amount exyended for iron bridges (if any),

For superstructure, including iron, per last report,

For superstructure, including iron, paid during the past year,

Total amount expended for superstructure, including iron,

For stations, buildings and fixtures, per last report,

For stations, buildings and fixtures paid during the past year,

Total amount expended for stations, buildings and fixtures,

For land, land-damages and fences, per last report,

For land, land-damages and fences, paid during the past year, Total amount expended for land, land-damages and fences,

For locomotives, per last report,

For locomotives, paid during the past year,

Total amount expended for locomotives,

For passenger and baggage cars, per last report,

For plassenger and baggage cars, paid during the past year, Total amount expended for passenger and baggage cars,

For merchandise cars, per last report,

For merchandise cars, paid during the past year,

Total amount experided for merchandise cars,

For engineering, per last renort,

For engineering, paid during the past year,

Total amount expended for engineering,

For agencies and other expenses, per last report,

For agencies and other expenses, paid during the past year,

Toual amount expended for agencies and other expenses,

Total cost of road and equipment,
$\{$ By charter, $\$ 300,000$; by vote, $\{\$ 275,000$; stock issued, $\$ 267,300$. 2673

$\$ 267,300$

267,300

No debts.

82,89872

3,60003

82,89872

3,60003

118,19705

11,46251

118,19705

25,65484

11,46251

25,65484

8,24972

8,24972

17,32070

17,32070

$\$ 267,38357$ 
Amount of assets or property held by the corporation in addition to the cost of the road,

\section{CHARACTERISTICS OF ROAD.}

Length of road,

Length of single main track,

Length of double main track,

Length of branches owned by the Company, stating whether they have a single or double track,

Aggregate length of sidings, and other tracks, excepting main tracks and branches,

Weight of rail, per yard, in main road,

Weight of rail, per yard, in branch roads, (specify the different weight per yard,)

Maximum grade, with its length, in main road,

Maximum grade, with its length, in branch roads,

Total rise and fall in main road,

Total rise and fall in branch roads,

Shortest radius of curvature, with length of curve, in main road,

Shortest radius of curvature, with length of curve, in branch roads,

Total degrees of curvature, in main road,

Total degrees of curvature in branch roads,

Total length of straight line, in main road,

Total length of straight line, in branches,

Aggregate length of wooden truss bridges,

Aggregate length of all other wooden bridges,

Aggregate length of iron bridges,

whole length of road unfenced on both sides,

Number of public ways crossed at grade,

Number of railroads crossed at grade,

Remarks,

Way stations for express trains,

Way stations for accommodation trains,

Flag stations,

Whole number of way stations,

Whole number of flag stations,

\section{DOINGS DURING THE YEAR.}

Miles run by passenger trains,

Miles run by freight trains,

Miles run by other trains,

Total miles run,

Number of passengers carried in the cars,

Number of passengers carried one mile

Number of tons of merchandise carried in the cars,

Number of tons of merchandise carried one mile,

Number of passengers carried one mile, to and from other roads,

Number of tons carried one mile, to and from other roads,

Rate of speed adopted for express passenger trains, including stops,

Average rate of speed actually attained by express passenger trains, including stops and detentions.

Rate of spe d adopted for accommodation trains.

Rate of speed actually attained by accommodation trains, including stops and detentions.

Average rate of speed actually attained by special trains, including stops and detentions.

Average rate of speed adopted for freight trains, including stops.

Estimated weight in tons of passenger cars (not iucluding passengers) hauled one mile,

Estimated weight in tons of merchandise cars (not including freight) hauled one mile,

\section{EXPENDITURES FOR WORKING THE ROAD.}

For repairs of road, maintenance of way, exclusive of wooden bridges, and renewals of iron,

For repairs of wooden bridges,

For wages of switchmen, average per month,

For wages of gate-keepers, average per month, $\$$

For wages of signal men, average per month,

For wages of watchmen, average per month, $\$$

Number of men employed, exclusive of those engaged in construction,

For removing ice and snow, (this item to include all labor, tools, repairs, and extra steam-power used,)

For repairs of fences, gates, houses for signal-men, gate-keepers, switchmen, tool-houses,

Total for maintenance of way,
13.16 miles.

13.16 miles.

But one track.

4949 feet.

$56 \mathrm{lbs}$.

39.61 feet-1.36 miles.

207.59 feet.

955.21

612

8.59 miles.

510 feet.

13

1

4

3

4

Operated by the Nashua and Lowell Railroad Corporation, under contract, a copy of which is hereunto annexed.

Reported by the Nashua and Lowell Railroad. 


\section{MOTIVE POWER AND CARS.}

For repairs of locomotives,

For new locomotives, to cover depreciation,

For repairs of passenger cars,

For new passenger cars, to cover depreciation,

For repairs of merchandise cars,

For new merchandise cars, to cover depreciation,

For repairs of gravel and other cars,

Total for maintenance of motive power and cars,

Number of engines,

Number of passenger cars,

Number of baggage cars,

Number of merchandise cars,

Number of gravel cars,

\section{MISCELLANEOUS.}

For fuel used by engines during the year, viz:-

Wood, number of cords. Cost of the same,

Coal, number of tons, (reckoning 2,240 lbs, to the ton.) Cost of same,

For oil used by cars and engines,

For waste and other material for cleaning,

For salaries, wages, and incidental expenses, chargeable to passenger department,

For salaries, wages, and incidental expenses, chargeable to

freight department,

For gratuities and damages,

For taxes and insurance,

For ferries,

For repairs of station bulldings, aqueducts, fixtures, furniture,

For renewals of iron, including laying down,

For new iron laid down, deducting the value of old iron taken np,

For amount paid other companies, in tolls for passengers and freight carried on their roads, specifying each company,

For amount paid other companies, as rent for use of their roads, specifying each company,

For salaries of president, treasurer, superintendent, law expenses, office expenses of the above offices, and all other expenses not included in any of the foregoing items, Tutal miscellaneous,

Total expenditures for working the road,

Total amount of interest paid during the year,

\section{INCOME DURING THE YEAR.}

For Passengers :-

1. On main road, Including branches owned by company,

2. To and from other roads, specifying what,

For Freight:-

1. On main road and branches owned by company,

2. To and from other connecting roads,

U. S. Mails,

Rents received for use of road as per contract, Total income,

Net earnings after deducting expenses,

\section{DIVIDENDS}

6 $\frac{1}{2}$ Per cent. Total, Surplus not divided.

Surplus last year,

Total surplus,

\section{ESTIMATED DEPRECIATION BEYOND THE RENEW-} ALS, viz. :

Of rnad and bridges,

Buildings,

Engines and cars,

Reported by the Nashua and Lowell Railroad.

Reported by the Nashua and Lowell Railroad.

$\$ 17563$

$\$ 17,70000$

Road run and kept in repair by the Nashua and Lowell Railroad Corporation. 


\section{MORTGAGE DEBTS.}

Amount of debts secured by mortgage of road and franchise, or any property of the corporation, per last report,

Mortgage debt paid since last report,

Increase of mortgage debt since last report,

Present amount of mortgage debts,

Number of mortgages on road and franchise, or any property of the corporation,

$$
\left.\begin{array}{l}
\text { TAPPAN WENTWORTH, } \\
\text { JOHN WRIGH', } \\
\text { SEWALL G. MACK, } \\
\text { WM. A. BURKE, }
\end{array}\right\} \begin{gathered}
\text { Directors of the } \\
\text { Stony Brook } \\
\text { Railroad Corporation }
\end{gathered}
$$

Middlesex ss., December 16, 1861. Then personally appeared Tappan Wentworth, John Wight, Sewall G. Mack and William A. Burke, and severally made oath to the truth of the foregoing statement by them subscribed.

Before

S. W. STICKNEY, Justice of the Peace. 


\section{CONTRACT.}

This Indenture, made the twenty-eighth day of May, A. D. 1860, between the Stony Brook Railroad Corporation, established by the LAWS of the Commonwealth of Massachusetts, OF the first part, and the Nashua and Lowell Ratlroad Corporation, estabLISHED BY THE LAWS OF THE CoMmonWealth OF MassachUSeTtS, AND by the LaWs of the State of New Hampshire, of the second PART,

Witnesseth, That whereas by the laws of said States, respectively, Railroad Corporations are authorized and empowered to contract with each other for the use of their roads, and for the transportation of freight, or passengers, and the conducting of all business connected therewith on their road, upon such conditions as may be mutually agreed upon, the parties hereto by virtue of such authority, did on the thirtieth day of March, One Thousand Eight Hundred and Forty-Eight, enter into a contract for the operation and management of the road of the party of the first part, by the party of the second part, which contract is still in force, and in full operation; and, whereas it is believed by both parties that under certain provisions of said contract, differences and legal controversies are liable to arise, and which differences and legal controversies it is for the true interest of the parties hereto to avoid, Now, Therefore, for the purpose of entering upon a more complete and satisfactory arrangement, such as the experience of the parties leads them to believe to be for their mutual advantage, and for the best interest of the public, it is hereby mutually agreed, that, upon the execution and entering upon of this contract, the agreement of March, 1848, aforesaid, shall cease and terminate, and shall not be reopened, litigated, or arbitrated, for or on account of any claim whatever of either party against the other.

And, the said Stony Brook Railroad Corporation, party of the first part, in consideration of the covenants herein contained, on the part of the Nashua and Lowell Railroad Corporation, party of the second part, to be 
kept and performed, and for the purposes aforesaid, doth deliver up to the said second party, their successors and assigns, and put them in full possession of the whole of their said Stony Brook Railroad, extending from the Nashua and Lowell Bailroad in North Chelmsford, to the Fitchburg Railroad, the Worcester and Nashua Railroad, and the Peterborough and Shirley Railroad, at Groton Junction; including all turnouts, switches, turn-tables, station houses, buildings and other property, whether included in their location or not; all of which is duly inventoried and appraised by appraisers mutually agreed upon, in the schedule thereof hereunto annexed Meaning hereby to deliver up to said Nashua and Lowell Railroad Corporation, and put them in possession of, as aforesaid, all the property of said Stony Brook Railroad Company of every description whatsoever, both real and personal, whether the same be particularly described herein or not; with the exception only of the bills, books of accounts, notes receivable, and all other debts and claims now due to the said Stony Brook Railroad Company on its own separate account. To have and to hold the same, all and singular to the said Nashua and Lowell Railroad Corporation, for the term of nineteen years, commencing on the first day of October A. D. One Thousand Eight Hundred and Fifty-nine.

And, the said second party may use, run, operate, manage, control and administer the said Railroad and property of the party of the first part, as fully as the said party of the first part might do. May transport freight, passengers and mails over and upon the same, and do and transact any other business authorized by the charter of said Stony Brook Railroad Company ; and, for the purposes and objects above set forth, and in consideration of the stipulations and things herein provided to be done and performed by said second party, said party of the first part do hereby deliver up and intrust their said Railroad and other property, to said party of the second part, for the term of nineteen years, as aforesaid, and do delegate to them all their powers to manage and regulate the same, and to collect tolls and income thereon, for the sole benefit of said second party.

The said first party also agree on their part to warrant and defend the said second party in the quiet possession of the said road and property during the term aforesaid, against the claims and demands, or attempted seizure or possession of said road or property, by any and all persons, creditors or claimants, upon suits or demands against said first party; and at its own separate cost and expense to keep up its corporate organization, and official Board of Directors, during the continuance of this agreement, and to pass and perform all such official acts as may from time to time become necessary for the legal and proper management of the road and property.

And said party of the second part, for themselves, their successors and assigns, in consideration of the premises, do hereby agree for and during 
the term of nineteen years as aforesaid, to manage said property, to do and perform all the transportation of persons and freight upon and over the Railroad of the party of the first part, and to furnish, manage, run and operate said Railroad at all times in a proper and suitable manner, so as to accommodate the public and the business of said road, and to collect the tolls and income thereof, as full satisfaction for the managing, operating and running of the same; and that they will at their own cost and expense maintain the said Stony Brook Railroad, as well as its real estate, embankments, bridges, tracks, depots and other buildings, and all other property, hereby intrusted to them, and return the same, or similar property, in lieu of such as may be sold, destroyed or worn out, (to be then appraised by men mutually agreed upon) at the expiration of the term herein mentioned, in absolutely as good order and condition as the same mag now be, (ordinary wear and tear, and loss of buildings by fire or tornado excepted) or make good the deficiency in money. And if the parties hereto shall be unable to mutually agree upon appraisers as aforesaid, each party shall name one appraiser, and the two so named shall choose a third, and the decision of said three appraisers, or a majority of them, shall be binding upon the parties.

All taxes assessed upon the said property in the manner now provided by law, are to be paid by the second party, as also any special tax on such property over and above the property tax upon the stockholders. But in case the Legislature shall levy a tax upon the Stony Brook Railroad, in lieu of the tax now assessed upon the stockholders, the same shall be paid by the first party.

And the party of the second part further agrees to pay the party of the first part, in consideration of the premises and agreements, and grants of the party of the first part, herein coutained, the sum of Seventeen Thousand and Seven Hundred Dollars annually. Payment of said sum to be made at the Office of the Nashua and Lowell Railroad Corporation, in the City of Nashua, one-half thereof, or Eight Thousand Eight Hundred and Fifty Dollars, on the first day of May, and the other half, or like sum, on the first day of November, in each and every year during the continuance, and for the time of this agreement, and also to grant to the officers for the time being of said Stony Brook Railroad Company, not exceeding seven in number, a free pass over the said Stony Brook Railroad, and over the Nashua and Lowell Railroad, on regular passenger trains, during the continuance of this contract, they taking the risk of all personal damage, detention or injury, or loss of baggage, from any cause whatsoever upon said passage.

And said party of the second part also agree to save harmless the said party of the first part from all suits, processes and costs, expenses and 
damages incident thereto, which shall arise in consequence of any accident happening on said Stony Brook Railroad, while in the hands of the second party, or by reason of the running of the same by them, or from any act, or neglect, or doing of the said party of the second part; and, further, to annually make all such returns and specifications to the Directors of the Stony Brook Railroad Company, as said Directors may require, in order to enable them to make all requisite reports to the Legislature of Massachusetts.

On the termination of this contract, the said first party shall assume and carry out, for a period not exceeding one year after such termination at the time aforesaid, any and all contracts made by said second party, for the transportation of mails, persons, expresses or freight over said road. The income from such contracts, upon said Stony Brook Road to inure to the benefit of said first party from and after such termination.

This contract shall relate back, and take effect upon and from the first day of October, A.D. 1859, and continue in force for the term of nineteen years thereafter; unless annulled by a vote of the Stockholders of either road as hereinafter provided; it being understood and agreed that either of said Corporations shall have the power to terminate the same at their first annual meeting next succeeding the date hereof, and not afterwards, and in case either Corporation shall so annul the same, then by such act the original contract of March, 1848, aforesaid, shall be fully revived, and the Stony Brook Railroad shall be run and operated by the Nashua and Lowell Railroad Corporation, under the provisions of the same, for the full term therein provided.

If any dispute shall arise from any of the provisions of this indenture. or upon any matter pertinent thereto, the same shall be submitted to the arbitration of three men, one to be appointed by each party, and the third by the two so appointed; and the decision of such men, or a major part thereof, shall be binding and conclusive upon the parties.

In witness whereof the said parties have, by their Committees duly authorized thereto, hereunto subscribed and affixed the respective seals of said Corporations, this twenty-eighth day of May, A. D. 1860.

The Nashua and Lowelu Ratlroad Corporation.

[L. S.]

[L. S. $]$
DANIEL S. RICHARDSON, \} By their J. G. ABBOTT.

JOHN WRIGHT. TAPPAN WENTWORTH. SEWALL G. MACK. 


\title{
R E P O R T
}

\author{
OF THE \\ D I R E C T R S \\ OF THE
}

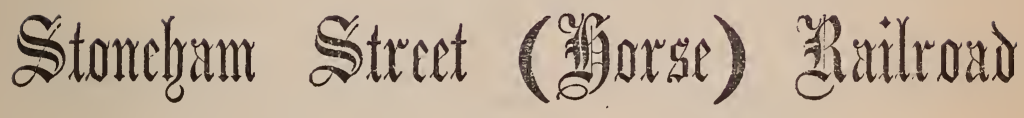

- COMPAN Y,

FOR THE YEAR ENDING NOVEMBER 30, 1861.

B O S T O N :

WRIGHT \& POTTER, PRINTERS, 4 SPRING LANE.

1861 . 



\title{
REPORT OF THE DIRECTORS
}

\author{
OF THE
}

\section{STONEHAM STREET (HORSE) R. R. COMPANY.}

For the year ending November 30, 1861. General Statutes, Chap. 63, Sects. 143, 144.

\section{Condition of the Company.}

1. Capital Stock, fixed by Charter, . . .

2. Capital Stock, as voted by the Company, . .

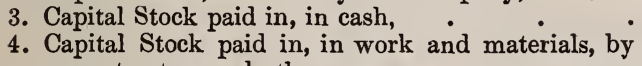

5. Funded debt,

6. Floating debt, $\cdot$ - $\cdot$ -

6. Floating debt, . $\quad$. . . .

7. $\quad \cdot \quad \cdot$ Notal debt,

8. Amount of above debt secured by mortgage of the road and franchise, or any property belonging to the corporation, or standing in its name, .

9. Number of mortgages on road and franchise, or any property of the corporation, specifying the number and amount of mortgages on road and franchise, and each kind of property,

10. Amount of assets on hand, exclusive of the road and equipment, and exclusive of all property on hand, used, or which is to be used, in running the road and keeping it in repair, .

None.

\section{Cost of the Road.}

11. Amount expended for labor in excavating for the track, laying foundation and rails,

12. Amount expended for timber for foundation,

13. Amount expended for iron and other metal for rails, chairs, spikes, or other articles, used in building the road,

14. Amount expended for paving,

15. Amount expended for paving

expended for paving stones, . .

17. Amount expended for interest, salaries of officers during construction of road, and other expenses not included in any of the above items, which have been included, on the books of the company, in the cost of the road, not including items of equipment or running expenses, as mentioned below,

18. Total cost of road,

19. Amount included in the present and in past years, among the running expenses for estimated or actual depreciation of the road,

20. Net cost of road, .

- None.

Unfinished.
None.

Built by contract for $\$ 31,000$.

None. 


\section{Cost of Equipment.}

21. Number of cars and cost, .

22. Number of horses and cost,

23. Cost of omnibuses, sleighs and other vehicles, excepting cars, owned by the Company,

24. Cost of land and buildings thereon when purchased,

25. Cost of buildings used for offices, stables, \&c., erected by the Company, or standing on land not owned by the Company,

26. Cost of other articles of equipment, (specifying what, ) .

27. Total cost of equipment

28. Amount included in the present and in past years in the running expenses for estimated or actual depreciation of any of the above items,

29. Net amount at which the equipment stands charged on the books of the Company, .

\section{Characteristics of the Road.}

30. Length of single main track.

31. Length of double main track,

32. Total length of road,

33. Length of branches owned by the Company, stating whether they have a single or double track,

34. Aggregate length of switches, sidings, turnouts, and other track, excepting main track and branches,

35.

Total length of rail, .

36 . Weight of rail used, per yard, (specifying whether of cast or rolled iron, ) .

37. Maximum grade, per mile, on road, with length of grade,

38. Shortest radius of curvature, with length of curve,

39. Greatest length of single track on road between two turnouts,

40. Total length of main track which is paved,

\section{Doings during the Year.}

41. Total number of miles run during the year,

42. Number of passengers carried in the cars,

43. Rate of speed adopted, including stops and detentions,

44. Rate of speed actually attainea, including stops and detentions, .

45. Number of persons employed, regularly, (specifying the occupations of each, 1 .

46. 'Total number of trips run during the year,

47. Average number of passengers each trip, .

\section{Fixpenditures for Working the Road.}

48. For repairs of road, including repairs of foundation, renewals of iron, and renewals of pavement,

49. For general repairs, including repairs of cars, omnibuses and harnesses, and for shoeing horses,
2 cars ; $\$ 1,275$.

Horses owned by lessee.

Owned by lessee.

None.

$\$ 1,00000$

10000 ; Snow plough.

$2 \frac{1}{2}$ miles finished.

None.

$2 \frac{1}{2}$ miles finished.

No branches; single track.

100 feet finished.

$2 \frac{1}{2}$ miles.

33 ibs. ; rolled.

6-100, and length 600 feet. 120 , length of curve 121 feet.

None.

13,000 miles.

32,000 passengers.

8 miles per hour.

8 miles per hour.

1 driver, 1 conductor.

5,200 trips.

$6 \frac{1}{8}$ passengers.

Leased for a term of years. 
50. For repairs of real estate, including repairs of buildings used as stables, offices, or for any other purposes, by the Company,

51 . For wages, including the wages of every person regularly employed, excepting the president, directors, superintendent, and treasurer,

52. For interest,

53. For taxes and insurance,

54. For tolls paid other companies for the right to pass over their roads,

55. For rent paid other companies for use of their roads, .

56. For provender, - to include cost of hay, grain, straw, or other articles used for the food and bedding of horses,

o7. For miscellaneous articles purchased during the year - such as harnesses, blankets, \&c., the use of which continues for one or more years - and not included in the cost of equipment, .

58. For loss on horses - that is to say, the difference between the present estimated value of the horses owned by the Company subtracted from the estimated value of those on hand at the commencement of the year, added to the cost of those purchased during the year ; or if this is the first report of the Company, then the difference between the estimated value of the horses on hand and their cost - giving the present average estimated value of each horse,

59. For incidental expenses, - to include printing, president's, directors', treasurer's, and superintendent's salaries, and all expenses other than those belonging to the actual working of the road,

60. For all other expenses,

61. For amount charged on the Company's books during the year, for estimated or actual depreciation of the following property :-

Cars, :
Horses,
Omnibuses, :
Real estate, :
Road,
Other property,

\section{Total,}

62. Total expenses,

\section{EARNINGS.}

63. Received from passengers in cars and omnibuses, and for tickets sold,

64. From other roads, as toll or rent for use of road,

65. From United States mails,

66. For sales of manure,

67 . From other sources,

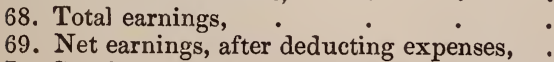

70. Surplus earnings of previous year, on hand,

71. Net earnings, as above,

72. Total surplus for payment of dividends, :
Repairs by lessee.

None.

None.

$\$ 5000$

$>$ None.

$\$ 10000$

Nothing.

Under lease from April 1, 1861. 
73. Dividends declared, during the year,

74. Total percentage of dividends, for the year,

75. Present surplus,

\section{Miscellaneous.}

76. Increase during the year -

Of capital stock, as fixed by the charter,

Of capital stock, as voted by the Company,

Of capital stock, paid in,

77. Increase of funded debt, during the year,

78. Increase of floating debt, during the year,

79. Decrease of funded debt, during the year,

80. Decrease of floating debt, during the year,

81. Increase of mortgage debt, during the year,

82. Decrease of mortgage debt, during the year,

83. Increase in cost of road, during the year, including amount charged for depreciation thereon,

84. Decrease in nominal cost of road, by amount charged for depreciation thereon,

85. Increase in cost of equipment, during the year, including amount charged for depreciation thereon, .

86. Decrease in cost of equipment, by sale of any portion thereof, or by amount charged for depreciation,

87. List of accidents on road during the year,

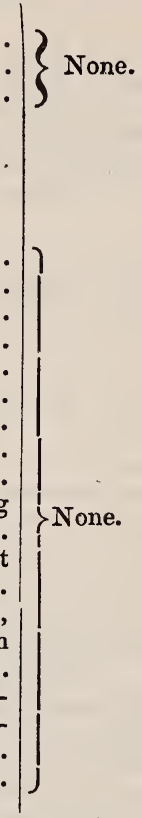

Directors of the Stoneham Street Railroad Co.

Mrdplesex, ss., December 21, 1861. Then personally appeared John Hill, Lyman Dike, Wm. Hurd, Wm. Tidd, Jr., and Luther Hill, and severally made oath to the truth of the foregoing statement, by them subscribed.

Before

A. V. LYNDE, Justice of the Peace. 



\section{EIGHTEENTH ANNUAL REPORT}

OF THE

\section{STOUGHTON BRANCH RAILROAD COMPANY.}

Return of the Stoughton Branch Railroad, for the year ending Nov. 30, 1861. General Statutes, Chap. 63, Secs. 162-165.

Capital Stock,

Number of shares of capital stock issued, Increase of capital, since last Report, Capital paid in, per last Report, Canital paid in since last Report Total amount of capital stock paid in, Funded debt, per last Report,

Funded debt paid since last Report, . Funded debt, increase of, since last Report, : Total present amount of funded debt,

Floating debt, per last Report, Floating debt paid since last Report, Floating debt, increase of, since last Report, Total present amount of floating debt,

Total present amount of funded and floating debt, Average rate of interest per annum, paid during the year,

Maximum amount of debts during the year,

\section{Cost of Road and Equiphent.}

For graduation and masonry, per last Report, For graduation and masonry, paid during past year, Total amount expended for graduation and masonry, For wooden bridges, per last Report,

For wooden bridges, paid during the past year, Total amount expended for wooden bridges, Total amount expended for iron bridges, (if any,) For superstructure, including iron, per last Report, For superstructure, including iron, paid during the past year,

Total amount expended for superstructure, including iron,

For stations, juildings and fixtures, per last Report, For stations, buildings and fixtures, paid during the past year, .

Total amount expended for stations, buildings and fixtures,

For land, land-damages and fences, per last Report, For land, land-damages and fences, paid during the past year

\section{$\$ 85,40000$}

854

None.

None.

85,40000

85,40000

No debts.

38,40198

None

1,77006

38,40198

None.

None.

30,86080

12,33678

8,94551
30,86080

1,770 06

12,33678 
Total amount expended for land, land damages and fences,

For locomotives, per last Report, :

For locomotives, paid during the past year, .

Total amount expended for locomotives,

For passenger and baggage cars, per last Report,

For passenger horse car and baggage cars, paid during the past year,

'Total amount expended for passenger and baggage cars,

For merchandise cars, per last Report,

For merchandise cars, paid during the past year,

Total amount expended for merchandise cars,

For engineering, per last Report,

For engineering, paid during the past year, .

Total amount expended for engineering, .

For agencies and other expenses, per last Report,

For agencies and other expenses, paid during the

past year,
Total amount expended for agencies and other expenses,

Total cost of road and equipment, $\cdot{ }^{\circ}$

Amount of assets or property held by the corporation in addition to the cost of the road, .

\section{Characteristics of Road.}

Length of the road,

Length of single main track, $•$

Length of double main track,

Length of branches owned by the Company, stating whether they have a single or double track,

Aggregate length of sidings, and other tracks, excepting main track and branches,

Weight of rail, per yard, in main road,

Weight of rail, per yard, in branch roads, (specifying the different weights per yard,)

Maximum grade, with its length, in main road,

Maximum grade, with its length, in branch roads,

Total rise and fall in main road,

Total rise and fall in branch roads, .

Shortest radius of curvature, with length of curve in main road,

Shortest radius of curvature, with length of curve, in branch roads,

Total degrees of curvature in main road, .

Total degrees of curvature in branch roads, .

Total length of straight line in main road, .

Total length of straight line in branches, .

Aggregate length of wooden truss bridges, .

Aggregate length of all other wooden bridges,

Aggregate length of iron bridges,

Whole length of road unfenced on both sides,

Number of public ways crossed at grade, .

Number of railroads crossed at grade,

Remarks,

Way stations for express trains,

Way stations for accommodation trains, .

4 miles, 222 feet.

4 miles, 222 feet.

None.

3,274 feet.

56 pounds.

None.

$46 \mathrm{ft}$. per mile for 740 feet.

$135_{100}^{51}$ feet.

1080 radius. Length of curvature 682 feet.

$172^{\circ}$

2 miles, 207 feet.

50 feet, 6 inches.

None, except the crossings

Six.

None.

None.

Three.

8,94551

$4,800 \quad 00$

2,88750 
Flag stations,

Whole number of way stations,

Whole number of flag stations,

\section{Doings during the Year.}

Miles run by passenger trains,

Miles run by freight trains,

Miles run by other trains,

Total miles run,

Number of passengers carried in the cars, .

Number of passengers carried one mile,

Number of tons of merchandise carried in the cars,

Number of tons of merchandise carried one mile,

Number of passengers carried one mile, to and from other roads,

Number of tons carried one mile, to and from other roads, .

Rate of speed adopted for express passenger trains, including stops,

Average rate of speed actually attained by express passenger trains, including stops and detentions,

Rate of speed adopted for accommodation trains,

Rate of speed actually attained by accommodation trains, including stops and detentions,

Average rate of speed actually attained by special trains, including stops and detentions,

Average rate of speed adopted for freight trains, including stops,

Estimated weight in tons of passenger cars, (not including passengers, ) bauled one mile,

Estimated weight in tons of merchandise cars, (not including freight,) bauled one mile,

\section{EXPENDITURES For WORKING THE ROAD.}

For repairs of road, maintenance of way, exclusive of wooden bridges, and renewals of iron, .

For repairs of wooden bridges,

For wages of switchmen, average per month, $\$$

For wages of gate-keepers, average per month, $\$$

For wages ef signal-men, average per month, $\$$

For wages of watchmen, average per month, $\$$

Number of men employed, exclusive of those engaged in construction,

For removing ice and snow, (this item to include all labor, tools, repairs, and extra steam-power used,)

For repairs of fences, gates, houses for sigual-men, gate-keepers, switchmen, tool-houses,

Total for maintenance of way,

\section{Motive Power and Cars.}

For repairs of locomotives

For new locomotives, to cover depreciation,

For repairs of passenger cars,

For new passenger horse-car,
None.

Three.

None.

5016.

[connected.

Freight \& passenger trains 864

66,461

189,542

$23,020.44$

$55,045.71$

169,583

$51,530.37$

No express trains.

18 miles per hour.

Done by Boston and Providence Railroad.

Nothing.

Done by Boston and

Providence Railroad.

2 Furnished by Boston and

$\zeta$ Providence Railroad. 32219

35000 
For repairs of merchandise cars,

For new merchandise cars, to cover depreciation, For repairs of gravel and other cars,

Total for maintenance of motive power and cars,

Number of engines,

Number of passenger cars,

Number of merchandise cars,

Number of gravel cars,

\section{Miscellaneous.}

For fuel used by engines during the year, viz :Wood, Coal,

For oil used by cars and engines,

For waste and other material for cleaning, .

For salaries, wages and incidental expenses, chargeable to passenger department,

For salaries, wages and incidental expenses, chargeable to freight department,

For gratuities and damages, .

For ferries,

For repairs of station buildings, aqueducts, fixtures, furniture,

For renewals of iron, including laying down,

For new iron laid down, deducting the value of old iron taken up,

For amount paid other companies, in tolls for passengers and freight carried on their roads, specifying each company. Easton Branch and Boston and Prov. R. R. Co.

For amount paid other companies, as rent for the use of their roads, specifying each company. Boston and Prov. R. R.

For operating horse car,

For salaries of president, treasurer, superintendent, law expenses, office expenses of the above offices, and all other expenses not included in any of the foregoing items,

Total miscellaneous, .

Total expenditures for working the road, .

Total amount of interest paid during the year,

\section{Income During the Year.}

For Passengers :-

1. On main road, includ'g branches owned by Co.

2. To and from other roads. Easton, and Boston \& Prov. R. R. .

For Freight:-

1. On main road and branches owned by Co.

2. To and fiorn other connecting roads,

U. S. Mails,

Rents. Store, cars and interest, $\quad \vdots$

Total income,

Net earnings after deducting expenses,
Furnished by Boston and Providence Railroad.

Paid by Boston and Providence Railroad.

657

2000

44729

2006

16,33444

4,338 96

17552

38278

22,39781

47526

15,58273

21495

$10,168 \quad 17$

$145 \quad 74$

1,45 ^ 44 


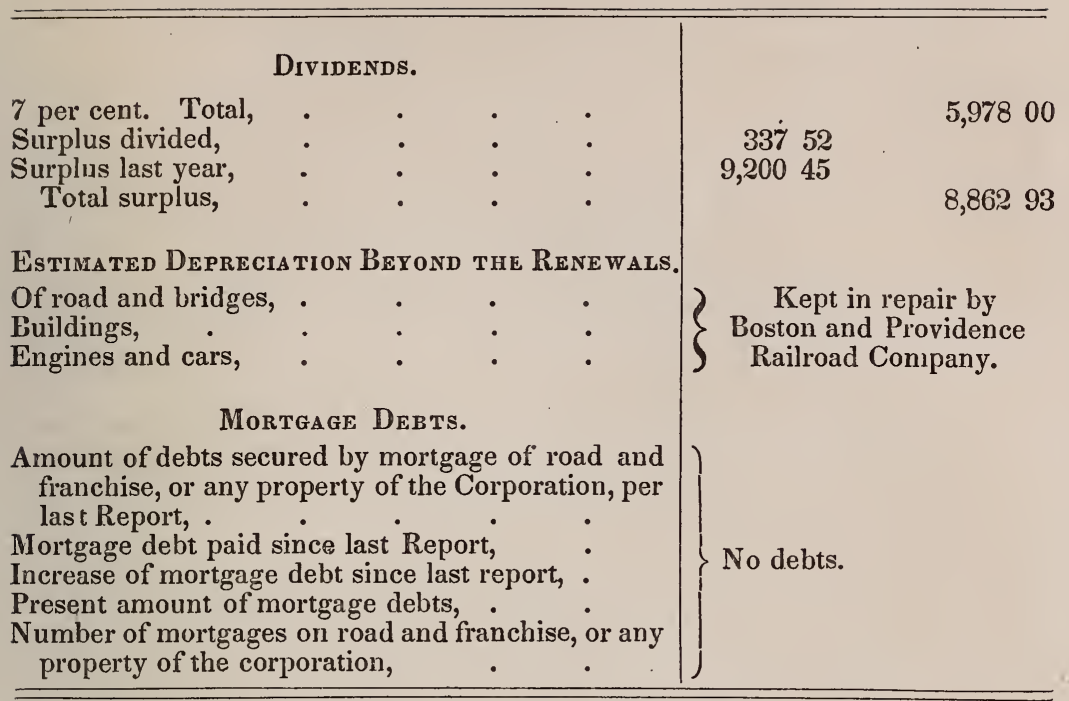

\section{F. W. LINCOLN, NATH'L MORTON, DiREcToRs. MARTIN WALES.}

Suffolk, ss. December 21, 1861. Then personally appeared F. W. Lincoln, Nath'l Morton and Martin Wales, and severally made oath to the truth of the foregoing statement subscribed by them.
Before
S. T. SNOW, Justice of the Peace. 

Twenty-Seventh

\section{ANNUAL REPORT}

OF THE

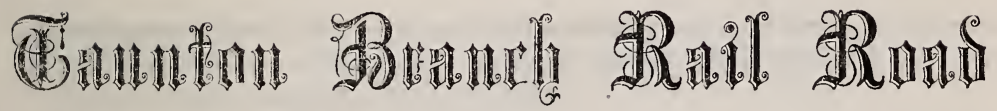

\section{COMPANY.}

\section{'TAUNTON:}

C. A. HACK'S BOOK PRESS, UNION BLOCK.

1861. 


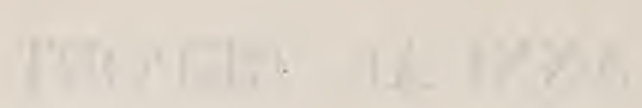

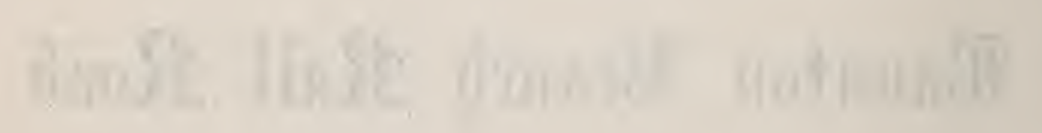

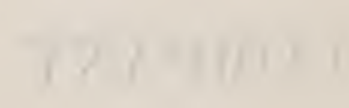




\title{
Twenty=Seventf) Anmual Repart
}

\author{
OF THE
}

\section{TAUNTON BRANCH RAIL ROAD}

\section{COMPANY.}

Report of the Taunton Branch Rail Road, for the year ending November 30th, 1861. General Statutes, chap. 63, sections 132 to 135.

Capital Stock,

Increase of Capital since last Report

Capital paid in per last report,

Capital paid in since last report,

Total amount of Capital Stock paid in,

Number of shares of Capital Stock issued,

Funded debt, per last report,

Funded debt paid, since last report,

Funded debt, increase of, since last report,

Floating debt, per last report,

Floating debt paid since last report,

Floating debt, increase of, since last report,

Total present amount of floating debt,

Total present amount of funded and floating debt,

Maximum amount of debts during the year,

Average rate of interest per annum, paid during the year,

\section{COST OF ROAD AND EQUIPMENT.}

For graduation and masomry, per last report,

For graduation and masonry, paid during the past year,

Total amount expended for graduation and masonry, For wooden bridges, per last report,

For wooden bridges, paid during the past year,

Total amount expended for wooden bridges,

Total amount expended for iron bridges, (if any,)

For superstructure, including iron, per last report,

For superstructure, including iron, paid during the past year,
$\$ 250,00000$

$\$ 250,00000$

250,00000

2500

89,85538

89,85538

92,24856 
Total amount expended for superstructure, including iron,

For stations, buildings, and fixtures, per last report,

For stations, buildings, and fixtures, paid during the past year,

Total amount expended for stations, buildings and fixtures,

For land, land damages, and fences, per last report,

For land, land damages, and fences, paid during the past

Total amount expended for land, land damages, and fences,

For locomotives, per last report, . . . .

For locomotives, paid during the past year, . .

Total amount expended for locomotives, . .

For passenger and baggage cars per last report,

For passenger and baggage cars, paid during the past year,

Total amount expended for passenger and baggage cars,

For merchandise cars per last report,

For merchandise cars paid during the past year, .

Total amount expended for merchandise cars,

For engineering per last report,

For engineering paid during the past year, :

Total amount expended for engineering, . .

For agencies and other expenses per last report,

For agencies and other expenses paid during the past year,

Total amount expended for agencies and other expenses, .

Charged off for depreciation of road and equipment,

Total cost of road and equipment,

Amount of assets of property held by the corporation in addition to the cost of the road,

47,05646

92,24856

30,72888

47,05649

16,38367

$30,7288 s$

$9,42166 \quad 16,38367$

13,92215

9,42166

13,92215

13,53927

13,53927

313,15606

63,15606

250,00000

58,38965

\section{CHARACTERISTICS OF THE ROAD.}

Length of road,

Length of single main track, $\quad \cdot \quad \cdot \quad \cdot \quad \cdot \quad \cdot$

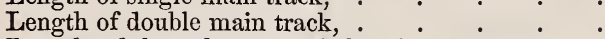

Length of branches owned by the Company, stating whether they have a single or double track,

Aggregate length of sidings and other tracks, excepting main tracks and branches,

Weight of rail per yard, in main road,

Weight of rail per yard, in branch roads,

Specify the different weights per yard,

Maximum grade, with its length, in main road,

Maximum grade, with its length, in branch roads, .

Total rise and fall in main road, .

Total rise and fall in branch roads,

Shortest radius of curvature, with length of curve, in main

Shortest radius of curvature, with length of curve in branch roads, 
Total degrees of curvature, in main road,

Total degrees of curvature in branch roads,

Total length of straight line in main road,

Total length of straight line in branches,

Aggregate length of wooden truss bridges,

Aggregate length of all other wooden bridges,

Aggregate length of iron bridges,

Whole length of road unfenced on both sides,

Number of public ways crossed at grade,

Number of railroads crossed at grade,

Remarks,

Way stations for express trains,

Way stations for accommodation trains,

Flag stations,

Whole number of way stations,

Whole number of flag stations,

\section{DOINGS DURING THE YEAR.}

Miles run by passenger trains,

Miles run by freight trains

Miles run by other trains,

Total miles run,

Number of passengers carried in the cars,

Number of tons of merchandise carried in the cars,

Number of tons of merchandise carried one milc,

Number of passengers carried one mile to and from other roads,

Number of tons carried one mile to and from other roads,

Rate of speed adopted for express passenger trains, including stops,

Average rate of speed actually attained by express passenger trains, including stops and detentions, .

Rate of speed adopted for accommodation trains, .

Rate of speed actually attained by accommodation trains, including stops and detentions,

Average rate of speed actually attained by special trains, including stops and detentions,

Average rate of speed adopted for freight trains, includstops and detentions,

Estimated weight in tons, of passenger cars, (not including passengers, ) hauled one mile,

Estimated weight in tons, of merchandise cars, (not including freight,) hauled one mile,

\section{EXPENDITURES FOR WORKING THE ROAD.}

For repairs of road, maintenance of way, exclusive of wooden bridges and renewal of iron,

For repairs of wooden bridges,

For wages of switchmen, average per month,

For wages of gate-keepers, average per month,

For wages of signal men, average per month,

For wages of watchmen, average per month,
70 degrees.

A street track.

11 miles.

2,200 feet.

900 feet.

19

1.

2.

1.

2.

35,570

14,420

44

50,034

106,190

$1,128,062$

37,707 tons, 1,942 lbs

408,970

74 "

$1,050,011$

396,125 tons, 74 lbs.

25 miles per hour.

25 miles per hour.

15 miles per hour.

5,56368

$\$ 37.50$

10.00

6.00

40.00 
Number of men employed, exclusive of those engaged in construction,

For removing ice and snow, (this item to include all labor, tools, repairs, and extra steam power used,

For repairs of fences, gates, houses for signal-men, gate keepers, switchmen, tool-houses,

'Total for maintenanee of way,

\section{MOTIVE POWER AND CARS.}

For repairs of locomotives,

For new locomotives, to cover depreciation, : .

For repairs of passenger cars,

For new passenger cars to cover depreciation, .

For repairs of merchandise cars, . . . .

For new merchandise cars to cover depreciation, .

For repairs of gravel and other ears,

Total for maintenance of motive power and cars .

Number of engines,

Number of passenger cars

Number of baggage cars,

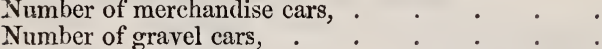

\section{MISCELLANEOUS.}

For fuel used by engines during the year, viz:-

Wood and Coal, cost of the same,

For Stations, Cars, Machine shop, \&c.,

For oil used by cars and engines,

For waste and other material for cleaning

For salaries, wages, and incidental expenses, clrargeable to passenger department, .

For salaries, wages and incidental expenses, chargeable to freight department,

For gratuities and damages, . $\quad . \quad . \quad$.

For taxes and insurance, . . . . . .

For ferries, . . . . . . . .

For repairs of station buildings, aqueducts, fixtures, and furniture, .

For renewals of iron, including laying down, .

For new iron laid down during the year, dedneting the value of old rail taken up,

For amount paid other companies, in tolls for passengers and freight carried on their roads, specifying each company, Boston and Providence Rail Road Company,

For amount paid other companies, as rent for use of their roads, specifying each company, N. B. \& T. R. R.

For salaries of president, treasurer, superintendent, law expenses, office expenses of the above offices and all other expenses not included in any of the foregoing items,

Total Miscellaneous,

Total expenditures for working the road Total amount of interest paid during the ycar, .
112

1675

7237

7,35167

4,47690

$1,961 \quad 55$

3,03707

9,47552

8

17

5

144

8,65575

1,37741

5,70895

9,62618

56440

99344

1,010 21

2,91427

57,71366

3,60135

3,89512

96,06074

112,88793 


\section{INCOME DURING THE YEAR.}

For Passengers :-

1. On main road, including branches owned by company,

2. To and from other roads, specifying what, Boston and Providence, and New Bedford and Taunton.

For Freight:-

1. On main road and branches owned by company,

2. To and from other connecting roads,

U. S. Mails, .

Rents and Interest,

Total income,

Net earnings after deducting expenses,

\section{DIVIDENDS.}

7 Per cent. Total

Surplus not divided, Surplus last year,

Total surplus,
2,62291

68,48624

79048

55,34142

1,20000

65025

129,09130

16,20337

17,50000

52,84257

51,54594

\section{WSTIMATED DEPRECIATION BEYOND THE RENEWALS, viz:-}

Roads and bridges,

Buildings,

Engines and cars,

\section{MORTGAGE DEBTS.}

Amount of debts, secured by mortgage of road and franchise, or any property of the Corporation, per last report,

Mortgage debt, paid since last report,

Increase of mortgage debt, since last report,

Present amount of mortgage debt,

Number of mortgages on road and fianchise, or any property of the Corporation, 
The Cars and Engines are owned by the Corporation, in common with the New Bedford and Taunton Rail Road Corporation, and the two roads are operated at their joint expense.

In addition to the number of miles run on this road, the Passenger Cars belonging to this Corporation have run ou the Boston and Providence Rail Road, 38,864 miles, of the expense of which, this Corporation has paid 11-31 parts; and the Freight Cars have rum 29,948 miles, of the expense of which, this Corporation has paid 52 per cent.

August 29th, 1861, Harrison Field was found dead, beside the road. Supposed to have been killed by the night train, while lying intoxicated, upon the track.

$\left.\begin{array}{l}\text { WM. A. CROCKER, } \\ \text { WM. STURGIS, } \\ \text { N. H. EMMONS, } \\ \text { T. B. WALES, } \\ \text { ED. BAYLIES, }\end{array}\right\} \begin{gathered}\text { Directors of the } \\ \text { Taunton Branch } \\ \text { Railroad Corporation. }\end{gathered}$

Suffolk ss. December 26, 1861 . Then personally appeared Wm. A. Crocker, Wm. Sturgis, Edmund Baylies, N. H. Emmons, and. T. B. Wales, and severally made oath to the truth of the foregoing statement, by them subscribed.

Before me,

E. PICKERING, Justice of the Perce. 


\title{
ELEVENTH ANNUAL REPORT
}

\author{
OF THE
}

\section{TROY AND GREENEIELD RAILROAD CO.}

Rieturn of the Troy and Greenfield Railroad, under the Acts of 1849, Chap. 191 : 1851, Chap. 112 ; 1854, Chap. 423 ; 1856, Chap. 165; 1857, Chaps. 40, 168 and 240 ; and 1858, Chap. 46.

Capital stock,

Number of shares of capital stock issued, Increase of capital, since last report, Capital paid in, per last report, Capital paid in, since last report, Total amount of capital stock paid in, Funded debt, per iast report, . . .

Funded debt, paid since last report, Funded debt, increase of since last report Total present amount of funded debt, Floating debt, per last report, Floating debt, paid since last report, Floating debt, increase of since last report, Total present anount of floating debt, 'Total present amount of funded and floating debt, Average rate of interest per annum, paicl curing the year,

Maximum amount of debts during the ycar, Cos't of RoAD AND EQUIPMENT.

For graduation and masonry, per last report,

For graduation and niasonry, paid during the past year,

Total amount expended for graduation and masonry

For wooden bridges, per last report,

For wooden bridges, paid during past year,

Total amount expended for wooden bridges,

'Total amount expended for iron bridges (if any)

For superstructure, including iron, paid during the past year

Total amount expended for superstructure, including iron,

For stations, buildings and fixtures, paid during the past year,

Total amount expended for stations, buildings and fixtures,

For land, land-damages, and fences, per last report,

For land, land-damages, and fences, paid during the past year,

'lotal amount expended for land, land-damages, and fences,
$\$ 2,500,000 \quad 00$ 688

$$
\begin{aligned}
& 914,586,73 \\
& 9,028,86 \\
& 379,284,00 \\
& 600,02 \pm, 00 \\
& 30,007,04 \\
& \text { 1.2, } 284,56
\end{aligned}
$$

j per cent.

$\$ 1,000,125,06$

$710,311,31$

$1,710,436,37$

All these items included in Construction Account.

$26,792.66$

$19,140,98$

$45,933,61$ 


\section{TROY AND GREENFIELD RAILROAD.}

For locomotives, per last year,

For locomutives paid during the past year.

Total amount expended for locomotives, .

For passenger and baggage cars, per last report,

For passenger and baggage cars, paid during the past year,

Total amount expended for passenger and baggage cars,

For merchandise cars, per last report,

For merchandise cars, paid during the past year,

Total amount expended for merchandise cars, .

For engineering, per last report.

For engineering, paid during the past year.

Total amount expended for engineering

For agencies and other expenses, per last report,

For agencies and other expenses, paid during the past year,

Total amount expended for agencies and other expenses,

Total cost of road and equipment,

Amount of assets or property, held by the corporation in addition to the cost of the road.

\section{Characteristics of Road.}

Length of Road,

Length of single main track,

Length of double main track, .

Length of branches owned by the company, stating whether they have a single or double track, .

Aggregrate length of sidings, and other tracks, excepting main tracks and branches,

Weight of rail, per yard, in main road, . . .

Weight of rail, per yard, in branch roads, . .

Specify the different weights, per yard, . . .

Maximum grade, with its length, in main road,

Total rise and fall in main roar,

Total rise and fall in branch roads,

Shortest radius of curvature, with lingth of curve in main road,

Shortest radius of curvature, with length of curve in branch roads,

Total degrees of curvatur • •

Total degrees of curvature in branch roads, .

Total length of straight line in main road,

Total length of straight line in branches,

Aggregate length of wooden truss bridges, .

Aggregate length of ail other wooden bridges,

Aggregate length of iron bridges,

Whole length of road unfenced on both sides,

Number of public ways crossed at grade,

Number of railroads crossed at grade,

Remarks,

Way stations for express trains, .

Way stations for accommodation trains,

$\$$

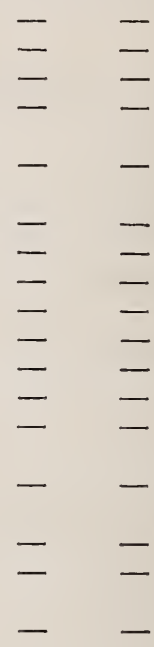

$425 \check{5}-100$ miles.

58 lbs.

Road in process of construction. 


\section{TROY AND GREENFIELD RAILROAD.}

\section{Flag Stations,}

Whole number of way stations,

Whole number of flag stations, $\quad: \quad: \quad: \quad$ :

INCOME DURING THE YEAR.

For Passengers :-

1. On main road, including branches owned by company,

2. To and from other roads, specifying what,

For Freight:-

1. On main road and branches owned by company,

2. To and from other connecting roads,

U. S. Mails,

\section{Rents,}

Total income, $\bullet \cdot \bullet \cdot \bullet \cdot \bullet \cdot$

Net earnings, after deducting expenses, : : : Mortange DeB's.

Amount of debts secured by mortgage of road and franchise, or any property of the Corporation, per last report, .

Mortgage debt paid since last report, $:$ :

Increase of mortgage debts since last report, .

Present amount of mortgage debts, .. . .

Number of mortgages on road and franchise, or any property of the corporation,

The road so far as completed, is leased to the Troy and Boston Railroad Company, and the income for the past year, is $\$ 8,000,00$.
$369,784,00$

$609, \tilde{5} 24,00$

$979,308,00$

Two.

D. N. CARPENTER, JAMES CHEEVER, LEWIS RICE,

H. HAUPT,

Directors of the Troy and Greenfield Railroad Corporation.

SUFfolk, ss. December 31,1861 . Then personally appeared Hernan Haupt, James Cheever and Lewis Rice, and severally made oath to the truth of the foregoing statement by them subscribed.

\section{Before}

A. S. Wienter, Justice of the Peace.

Franklin, ss. December 28, 1861. Then personally appeared David $\mathrm{N}$. Carpenter, and made oath to the truth of the foregoing statement. 



\section{R E P O R T}

OF THE

\section{DIRECTORS}

OF THE

Suffolk edailroad (1) ompand,

FOR THE

YEAR ENDING, NOVEMBER 30, 1861.

B O S T ON :

WILLIAM M. KENDALL, PRINTEP, 36 WASHiNgtoN StREET.

1862. 



\section{R E P O R T.}

\section{CONDITION OF THE COMPANY.}

Capital Stock, fixed by charter,................. \$300,000 00

Capital Stock, as voted by the Company............. 150,00000

Capital Stock paid in, in cash............................ 10,000 00

Capital Stock paid in, in work and materials, by coutractors and

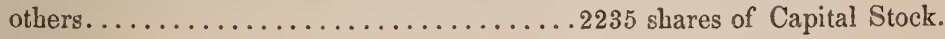

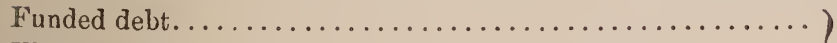

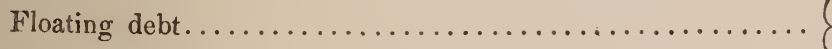

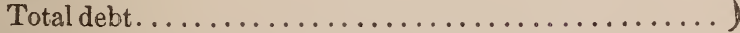

Amount of above debt secured by mortgage of the road and

franchise, or any property belonging to the corporation,

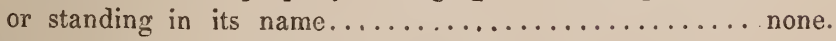

Number of mortgages on road and franchise, or any property of the corporation, specifying the number and amount of mortgages on road and franchise, and each kind of property, none.

Amount of assets on hand, exclusive of the road and equipment, and exclusive of all property on hand, used, or which is to be used, in running the road and keeping it in repair.....

\section{COST OF THE ROAD.}

Amount experided for labor in excavating for the track, laying

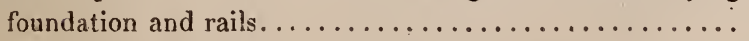
Amount expended for timber for foundation............ Built by conAmount expended for iron and other metal for rails, chairs, $\}$ tract. Items spikes, or other articles, used in building the road....... unknown. Amount expended for paving. Amount expended for paring-stones. 


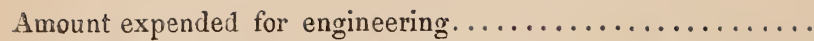

Amount expended for interest, salaries of officers during construction of road, and other expenses not included in any of the above items, which have been included on the books of the Company, in the cost of the road, not including items of equipment or running expenses, as mentioned

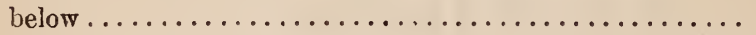

This item includes the altering of the Ferry Boats and Drops, Nachinery to adjust them, laying of Rails, extra Switches and Turnouts, and extension of track, and building new track in Haverhill, Causeway, Merrimac, and Portland, and corner of Boylston Street, and repaving Causeway and other Streets. J

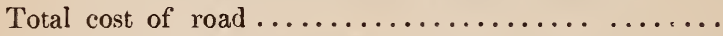

Amount included in the present and in past years, among the running expenses, for estimated or actual depreciation of

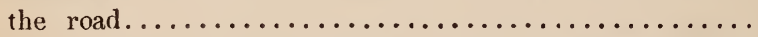

Net 'ost of road. Paid to contractors and others 2235 shares of Capital Stock.

Paid cash to sundry persons, $\ldots \ldots \ldots \ldots \ldots \ldots \ldots \ldots \ldots$

\section{COST OF EQUIPMENT.}

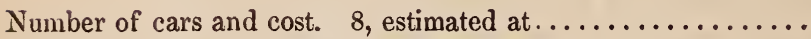
6,00000

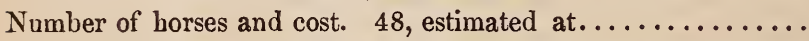
6,00000

Cost of omnibuses, sleighs, and other vehicles, excepting cars,

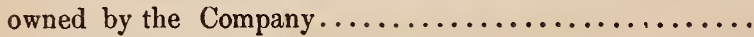

Cost of land and buildings thereon when purchased.........

Cost of buildings used for offices, stables, \&c., erected by the Company, or standing on land not owned by the Company, Cost of other articles of equipment, (specifying what.) Harness, Blankets, Halters, Tools, Stable and Office Furniture, Materials for use in repairing road and equipment..........

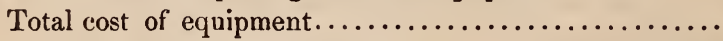

Arnount included in the present and in past years in the running expenses for estimated or actual depreciation of any of the above items. Estimated at value.

Net amount at which the equipment stands charged on the books

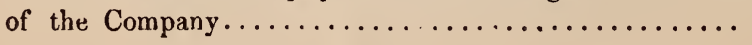




\section{CHARACTERISTICS OF THE ROAD.}

Length of single main track. . . . . . . . . . . . . . 16,401 feet.

Length of double main track..................

Total length of road, (equal to 4 miles and 2,527 feet single track.)

Length of branches owned by the Company, stating whether they have a single or double track.................. Aggregate length of switches, sidings, turnouts, and other track, excepting main track and branches $\ldots \ldots \ldots \ldots \ldots \ldots \ldots \ldots$

Total length of rail..................... 47,294 feet.

Weight of rail used, per yard, (speeifying whether of cast or Rolled-45 \&

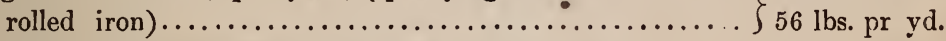

Maximum grade per mile on road, with length of grade......

Shortest radius of curvature, with length of curve......... 36 feet radius.

Greatest length of single track on road between two turnouts,

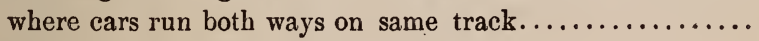

846 feet.

Total length of main track which is paved................ Wholly paved.

\section{DOINGS DURING THE YEAR.}

Total number of miles run during the year by East Boston cars, 118,477

Number of passengers carried in East Boston cars, $\quad 380,886$ Number of passengers carried in Winnisimmet cars, $\quad 211,132$ Number of passengers carried in Lynn cars..... $\quad 132,930$

Rate of speed adopted, including stops and detentions......... Rate of speed actually attained, including stops and detentions, Number of persons employed regularly, (specifying the occupations of each.) 1 Superintendent, 2 Superintendent's Clerks, 7 Conductors, 9 Drivers, 4 Hostlers, 2 Watchmen,

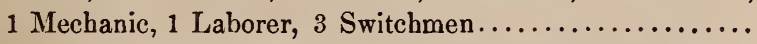
Total number of trips run during the year by East Boston cars, Average number of passengers each trip................. 


\section{EXPENDITURES FOR WORKING THE ROAD.}

For repairs of road, including repairs of foundation, renewals

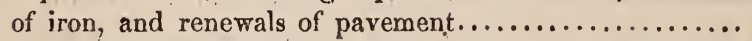

Eor general repairs, including repairs of cars, omnibuses, and harnesses, and for shoeing borses................

For repairs of real estate, including repairs of buildings used as stables, offices, or for any other purposes, by the Company.

For wages, including the wages of every person regularly employed, excepting the president, directors, superintendent,

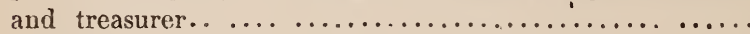

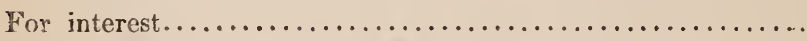

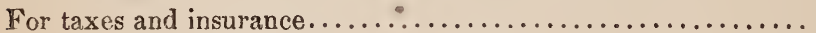

9,50520

$558 \quad 80$

10116

3,70121

For tolls paid other companies for the right to pass over the ferry, For rent paid other companies for use of their roads...........

For provender,- to include cost of hay, grain, straw, or other. articles used for the food and bedding of horses............

For miscellaneous articles purchased during the year, - such as haruesses, blankets, etc., the use of which continues for one or more years,-and not included in the cost of equipment. Nothing paid. 6,30807 All included in equipment.

For loss on horses,-that is to say, the difference between the present estinaled value of the horses ovpned by the Company subtracted from the estimated value of those on hand at the commencement of the year, added to the cost of those purchased during the year; or if this is the first report of the Company, then the difference between the estimated value of the horses on hand and their cost,giving the present average estimated value of each horse..

For incidental expenses, - to include clerk's, and treasurer's, and superintendent's salaries, and all expenses other than those belonging to the actual working of the road, and

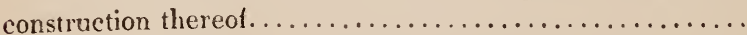

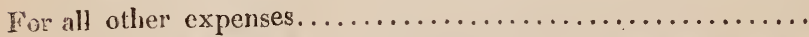

For amount charged on the Company's books during the year, for estimated or actual depreciation of the following property :

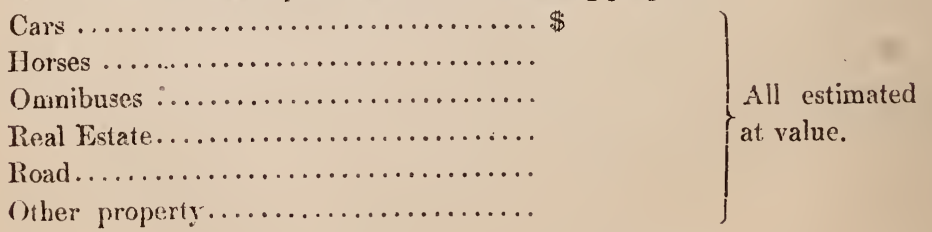

Total

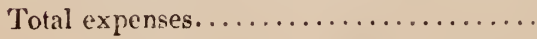




\section{EARNINGS.}

Received from passengers in cars and omnibuses, and for tickets sold, including amount due from Lynn Railroad Company,

From other roads, as toll or rent for use of road..............

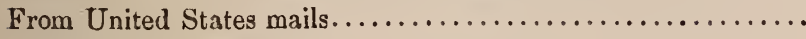

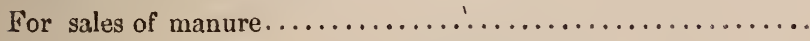

From other sources...........................................

Total earnings

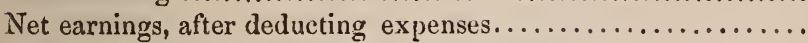

Surplus earnings of previous year, on liand.

$1,626 \quad 25$

Net earnings, as above.

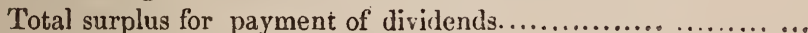

Dividends declared during the year.............................

Total percentage of dividends for the year.....................

Present surplus.

$506 \quad 77$

None.

$506 \quad 77$

\section{MISCELLANEOUS.}

Increase during the year:-

Of capital stock, as fixed by the charter . . . . . . . .

Of capital stock, as voted by the Company ........

Of capital stock, (35 shares) .............

Increase of funded debt during the year ..........

Increase of floating debt during the year .........

Decrease of funded debt during the year ...........

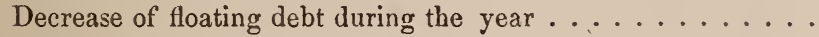

Increase of mortgage debt during the year .........

Decrease of mortgage debt during the year .........

Increase in cost of road during the year, including amount charged for depreciation thereon ............

Nonie.

None.

Decrease in nominal cost of road, by amount charged for depre-

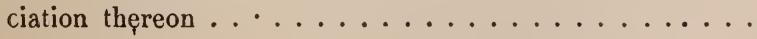


Increase in cost of equipment during the year, including amoent

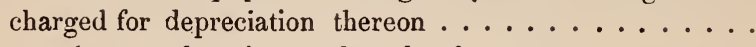

Decrease in cost of equipment by sale of any portion thereof, or by amount charged for depreciation ...........

List of accidents on road during the year ...........

None.

ASA FISK,

D. L. WEBSTER, CHAS. H. TYLER, JOHN G. WEBSTER, Directors of the GEQ. H. PLUMMER,

SUFFOLK, SS., December 31, 1861.

Then personally appeared Asa Fisk, D. L. Webster, Chas. H. Tyler, John G. Webster, and Geo. H. Plummer, and severally made oath that the foregoing statement by them subscribed is true to the best of their knowledge and belief.

Before ALBERT BOWKER,

Justice of the Peace. 


\section{R E P O R T}

or The

\section{VERMONT AND MASSACHUSETTS}

\section{RAILROAD CORPORATION.} FOR THE YEAR ENDING NOVEMBR 30, 1861.

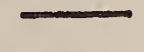

\section{B O S T O N :}

1861. 



\section{R E P O R T}

OF THE

\section{VERMONT AND MASSACHUSETTS RAILROAD}

\section{O R P O R A T I O N.}

Report of the Directors of the Vermont and Massachusetts Railroad Corporation for the year ending November 30, 1861.

Capital stock, including the Greentield Branch and Vermont portion, ......................... Number of shares of capital stock issued,............ Increase of capital, since last report,............. Capital paid in, per last report,.................. Capital paid in since last report,$\ldots \ldots \ldots \ldots \ldots \ldots \ldots$ Total amount of capital stock paid in,........... Funded debt, per last report, .................... Funded debt, paid since last report,.............. Funded debt, increase of, since last report,........ Total present amount of funded debt,............ Floating debt, per last report,.$\ldots \ldots \ldots \ldots \ldots \ldots$ Floating debt, paid since last report,.............. Floating debt, increase of, since last report,......... Total present amount of floating debt........... Total present amount of funded and floating debt,... Average rate of interest per annum, paid during the

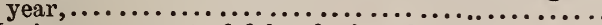
Maximum amount of debts during the year,.........

\section{Cost of Road and EQdipment.}

For graduation and masonry, per last report,...... For graduation and masonry, paid during the past

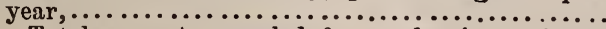
Total amount expended for graduation and ma-

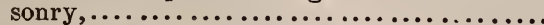

For wooden bridges, per last report, $\ldots \ldots \ldots \ldots \ldots \ldots$ For wooden bridges, paid during the last year,...... Total amount expended for wooden tridges, ... Total amount expended for iron bridges (if any,)....

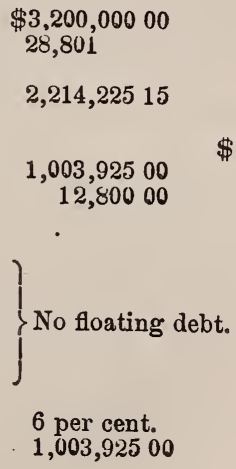

$\$ 1,461,323,12$

199,39531 
For superstrusture, including iron, per last report,..

For superstructure, includiug iron, paid during the

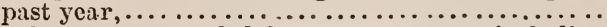

Total amount expended for superstructure, including

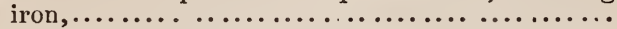

For stations, buildings and fixtures, per last report,

For stations, buildings and fixtures paid during the

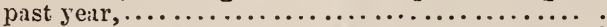

Total amount expended for stations, buildings and

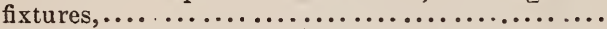
For land, land-damages and fences, per last report,

For land, land-damages and fences, pail during the

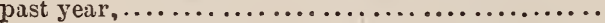
Total amount expended for land, land damages

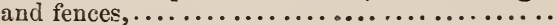

For locomotives, per last report, ..............

For locomotives, pard during the past jear,.........

T'utal amount expended for locomotives,........... For passenger and bag gage cars, per last report,....

For passenger and baggage cars, paid during the

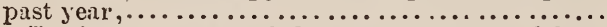

'Iotal amount expended for passenger and bag-

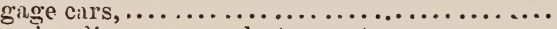

For merchandise cars, per last report,...........

Fur merchandise cars, paid during the past year,....

Total amount expended fur merchandise cars, ....

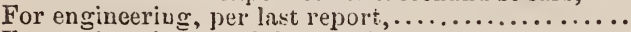

For engineering, paid during the pist year, .......

'lotal amount expended Ior engineering, ........

For agencies and otlier expenses, salaries, \&c., during the coustruction of the road,............

For dividends of interest, discount on bonds, \&c.,...

Total cost of road and equipment,........... Amount of assets or property held by the corporation in addition to the cost of the roid,...........

Charged to Greenfield Branch in addition to above,..

\section{Characteristics of Road.}

Length of road,$\ldots \ldots \ldots \ldots \ldots \ldots \ldots \ldots \ldots \ldots \ldots \ldots$ Length of single main track,................ Length of double main track,.................. Length of branches owned by the company, stating whether they have a single or double track,.......

Aggregate length of sidings, and other tracks, ex-

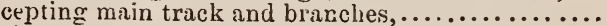

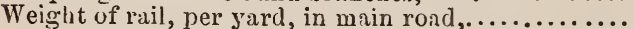

Weight of rail, per yard, in branch roads, (specify the different weights, per yard, $). . \ldots \ldots \ldots \ldots \ldots$. Maximum grade, with its length, in main road,..... Maximum grade, with its length, in branch roads,... Total rise and fill in nuain road,$\ldots \ldots \ldots \ldots \ldots \ldots . .$.

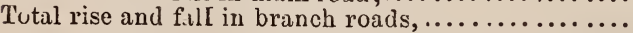

Shortest radius of curvature, with length of curve,

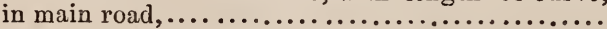

Shortest radius of curvature, with length of curve, in

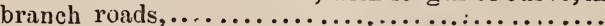

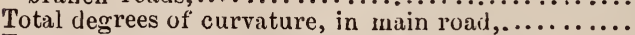
Total degrees of curvature, in branch roads,......... T'otal length of straight line, in main road,.........

T'otal length of straight line, in hranches,.......... Aggregate length of wooden truss hridges, ......... Aggregate lerigth of all other wooden bridges,....... Aggregate length of iron bridges,..............
600,42201

129,27436

600,42201

129,27436

181,21885

181,21885

95,63862

95,63862

20,19000

91,51483

$<0,19000$

56,87204

91,51489

53,57204

110,27131

332,29502

$\$ 3,2 C 8,41553$

248,49508

69 miles.

69

None.

8 miles single track.

Abcut $5 \frac{1}{2}$ miles.

56 pounds.

\section{$59 \quad 66$}

58 feet for $16-10$ miles.

45 feet pir mile, $3 \frac{1}{2}$ miles.

Rise 808 teet, fill 930 feet. " 81 " " 168 ".

$\{1,000$ feet for 1,900 feet, ex

$\{$ cept at Grout's, where it is 924 fect for 1,200 feet.

1,000 feet for 400 feet.

$3,314^{\circ}$

$607^{\circ}$

27 3-4 iniles.

3 9-10 inles. 6,738 feet. 
Whole len Number of public ways crossed at grade,.......... Number of railroads crossed at grade, ............

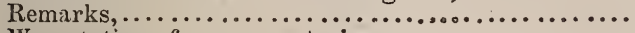

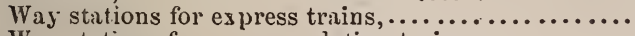
Way stitions for accommodation trains,...........

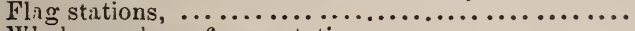

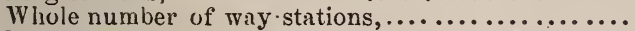

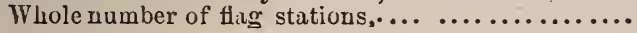

\section{Doings during the Year.}

Miles run by passenger trains,..............

Miles run by treight trains, ..................

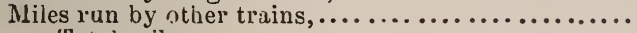

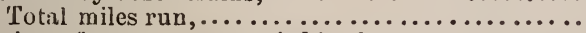

Number of passengers carried in the cars, ..........

Number of passengers carried one mile,............

Number of tons of merchandise carried in the cars,...

Number of tons of merchandise carried one mile,....

Number of pissengers carried one mile, to and from

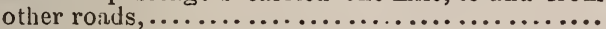

Number of turs carried one mile, to and from other roids,

Rate of speed adopted fur express passenger triins,

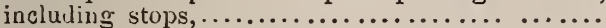

Average rate of speed actually attined by express passenger trains, iucluding stops and detentiuns,..

Rate of speed adupted fur aceommodation trains, ....

Rate of speed ictually attained by accommodation trilins, including stops and detentions, ...........

Average rate of speed actually attained by special trains, including stops and detentions, ...........

Average rate of speed indopted for freight trains, including stops and detentions, .................

Estimated weight in tons of passenger cars, (not including pissengers, hauled one mile,..........

Estimated weight in tuns of merchandise cars, (not including freight, ) hanled one mile,............

\section{Expenditures tor Working the Road.}

For repairs of road, maintenance of way, exclusive of woolen bridges, and renewals of iron,..........

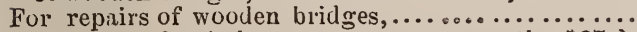
For wiges of switelımen, average per month, \$27, For wages of giate-keeper's, average per month, $\$ 15$, For wages of signal-men, average per month, $\$ 27$, For wages of watchmen, average per month, $\$ 30$, Number of men employed, exclusive of those engiged

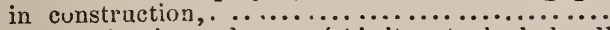

For removing ice and snow, (this item to include all labor, touls, repairs, and extra steam-power used,) For repairs of fences, gates, houses for sigual-men, gate-keepers, switchmen, tool-houses,...........

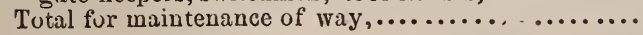

\section{Motive Power and Cars.}

For repairs of locomotives, $\ldots \ldots \ldots \ldots \ldots \ldots \ldots$ For new locomotives, to cover depreciation,........... For repairs of passenger cars, ................... For new passenger c:rrs, to cover depreciation, ....... For repairs of merchandise cars,$\ldots \ldots \ldots \ldots \ldots \ldots .$. For new merchandise cars to cover depreciation,... For repairs of gravel and other cars,...............
63

1

17

3

17

3

50,734

37,814

1,991

73,700

$1,557,549$

$58,773379-1000$

$1,286,143832-1000$

$1,025,534$

$1,164,595653-1000$

No such trains.

No such trains.

22 miles per hour.

25 miles per hour.

25 miles per hour. 7

10 miles per hour.

17,38704

2,86337

2,46597

140 men.

1,39107

1,71185

25,81930

12,82930

3,89700

9,33463

27565

90,539

None.

,539 
Total for maintenance of motive power and cars, Number of engines, ..........................

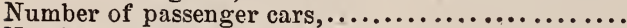
Number of baggage cars,......................

Number of merchandise cars, $\ldots \ldots \ldots \ldots \ldots \ldots \ldots . . .6$

Number of gravel cars, $\ldots . \ldots \ldots \ldots \ldots \ldots \ldots \ldots . .$.

\section{Miscellaneous.}

For fuel used by engines, during the year, viz.......

1. Wood, number of cords, 2,471 Cost of the same $, \ldots \ldots \ldots \ldots \ldots \ldots \ldots \ldots \ldots 6,95764$

2. Coal, number of tons, (reckoning 2,240 lbs. to the ton,) 153. Cost of same, $\$ 1,07100$ 473 cords of wood used by stationary engine, \&c., \&c, ................ \$1,261 00

For oil used by cars and engines, 1773 gallons........ For waste and other material for cleaning, $3913 \mathrm{lbs..}$

For salaries, wages and incidental expenses, chargeable to passenger department,................... For salaries, wages and incidental expenses, chargeable to freight department,......................

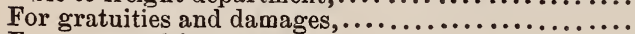

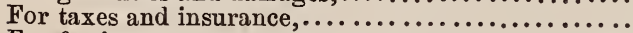

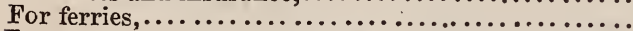

For repairs of station buildings, aqueducts, fixtures,

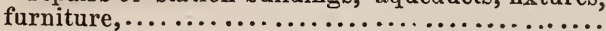

For renewals of iron, (laying down included else-

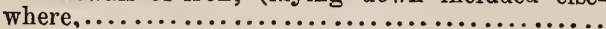

For new iron laid down, deducting the value of old

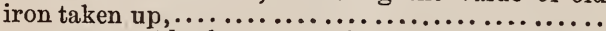

For amount paid other companies, in tolls for passengers and freight carried on their roads, specifying

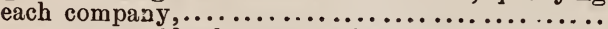

For amount paid other companies, as rent for use of their roads, specifying each company. Connecticut River Railroad Co.,......................

For salaries of president, treasurer, superintendent, law expenses, cffice expenses of the above offices, and all other expenses not included in any of the foregoing items, .............................

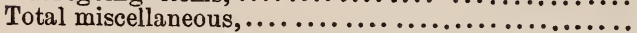

11

8

179

6

1,77377

32708

10,92875

12,21920

98989

2,62724

1,73248

4,86042

1,50000

$6.505 \stackrel{2}{4} 6$

52,75393

104,90981

56,38749

\section{Income during the year.}

\section{For Passengers :-}

1. On main road, including branches owned by ? company,.........................

2. To and from other roals, specifyiug what....

\section{For Freight:-}

1. On main road, and branches owned by com-? pany,..............................

2. To and from other connecting roads,..........

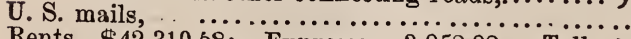
Rents, $\$ 42,310.38$; Expresses, 3,95292 ; Tolls, ? $\$ 76900 ;$ Miscellaneous, $\$ 77818, \ldots . . . \ldots .$.

Total income,$\ldots \ldots \ldots \ldots \ldots \ldots \ldots \ldots \ldots \ldots \ldots . . . \ldots \ldots$ Net earnings, deducting expenses, $. \ldots \ldots \ldots \ldots \ldots \ldots \ldots . .$. 
Dividends.

-per cent. Total,.........................

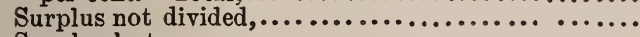

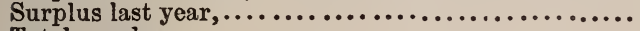
Total surplus, .............................

Estimated Depreciation beyond the Renewals, viz :-

Road and bridges,

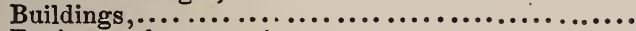
Engines and cars,

\section{Mortgage Debts.}

Amount of debts, secured by mortgage of road and franchise, or any property of the corporation, per last report, ................................ Mortgage debt, paid since last report,.............. Increase of Mortgage debt since last report,....... Total present amount of mortgage debt, ............

Number of mortgages on road and franchise, or any property of the corporation....................

The foregoing report is respectfully submitted by

\section{JAMES CHEEVER, JOSEPH GOODHUE, D. N. CARPENTER, J. J. SWIFT,}

Boston, Defember 26, 1861.

ACCIDENT.-February 20, 1861. Between Gardner and Ashburnham, on freight train, Dwight J. Weaver, brakeman, came in collision with a bridge of public way, and was instantly killed.

Middlesex, ss., December 26, 1861.

Then personally appeared James Cheever, Joseph Goodhue, D. N. Carpenter, and John J. Swift, and severally made oath to the truth of the foregoing statement, by them subscribed, according to their best knowledge and belief.

Before, EDMUND G. LUCAS, Justice of the Peace. 



\section{TH I R D RE T UR N O F}

\section{THE WEST CAMBRIDGE HORSE-RAILROAD COMPANY}

TO THE

\section{SECRETARY OF THE COMMONWEALTH OF MASSACHUSETTS,}

\section{For the Year ending November 30th, 1861.}

UNDER GeNerAL STATUTES, ChAPTER 63, sections 143, 144.

\section{Condition of the Company.}

Capital Stock, fixed by charter, . . . . . . . . . $\$ 50,000.00$ Capital Stock, as voted by the Company, .

Capital Stock paid in, in cash

Capital stock paid in, in work and materials, by contractors and others,

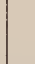

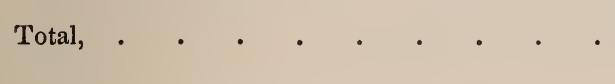

None.

$\$ 12,850.00$

Funded debt,

Floating debt,

Total debt,

Amount of above debt secured by mortgage of the road and franchise, or any property belonging to the corporation, or standing in its name,

None.

Number of mortgages on road and franchise, or any property of the corporation, specifying the number and amount of mortgages on road and franchise, and each kind of property,

None.

Amount of assets on hand, exclusive of the road and equipment, and exclusive of all property on hand, used, or which is to be used, in running the road and keeping it in repair,

None.

. . . $\frac{\$ 120.40}{\$ 120.40}$

None.

Nothing. 


\section{Cost of the Road.}

Amount expended for labor in excavating for the track, laying foundation and rails,

For timber for foundation,

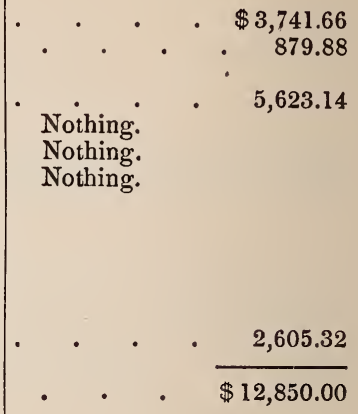

Total cost of the road,

Amount included, in the present and in past years, among the running expenses for estimated or actual depreciation of the road,

Net cost of road,

\section{Characteristics of the Road.}

Length of single main track,

Length of double main track,

Total length of road,

Length of branches owned by the Company, stating whether they have a single or double track.

Aggregate length of switches, sidings, turn-outs, and other track, excepting main track and branches,

Total length of rail

Weight of rail used, per yard, specifying whether of cast or rolled iron.

Maximum grade, per mile, on road, with length of grade,

Shortest radius of curvature, with length of curve,

Greatest length of single track on road between two turn-outs,

Total length of main track which is paved, . . .

\section{DoINGS DURING THE YeAR.**}

Total number of miles run during the year,

Number of passengers carried in the cars, .

Rate of speed adopted, including stops and detentions,

Rate of speed actually attained, including stops and detentions,

Number of persons employed, regularly (specifying the occupations of each).

Total number of trips run during the year,

Average number of passengers each trip,
No double track.

8,325 feet.

None.

498 feet.

17,148 feet.

( Rolled iron. -33 lbs. to the yard.

s 100 feet per mile : 1,600

feet in length.

48 feet ; 45 feet in length.

1,200 feet.

None.

8 miles per hour.

8 miles per hour.
8,325 feet.

* The doings for the year are from a Report from the Lessee to November 30 th, 1861. 
The road being under lease, the Company are unable to give any replies to the interrogatories in the blank form of return furnished by the Secretary of the Commonwealth, under the heads of Cost of Equipment, Earnings, Expenditures for Working the Road, and Miscellaneous.

$$
\left.\begin{array}{l}
\text { JOHN SCHOULER, } \\
\text { BENJA. POLANI, } \\
\text { GEORGE PEIRCE, }
\end{array}\right\} \begin{gathered}
\text { Directors of the } \\
\text { West Cambridge Horse- } \\
\text { Railroad Company. }
\end{gathered}
$$

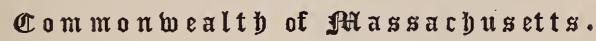

SUFFOLK ss.

December 23, 1861.

Then personally appeared John Schouler, Benja. Poland, and George Peirce, and made oath that the foregoing Return, by them subscribed, is true, according to their best knowledge and belief.

Before me,

WM. E. PARMENTER, Justice of the Peace. 



\section{F I F T H}

\section{ANNUAL RETURN}

OF THE

\section{WEST ROXBURY RAILROAD}

( H O R S )

COR P O R A T I O N.

FOR THE YEAR ENDING NOVEMBER 30, 1861.

BOS T O N :

PRESS OF JOSEPH G. TORREY, 32 CONGRESS STREET.

1862 . 


\section{FIFTH ANNUAL RETURN}

OE THÉ

\section{WEST ROXBURY HORSE RAILROAD \\ C O M P A N Y, \\ FOR THE YEAR ENDING NOVEMBER 30, 1861.}

[This return to be made to the Secretary of the Commonwealth, together with 1,000 printed copies of the same, on or before the first Wednesday of January 1862.-General Statutes, Chap. 63, Sec. 143, 144.]

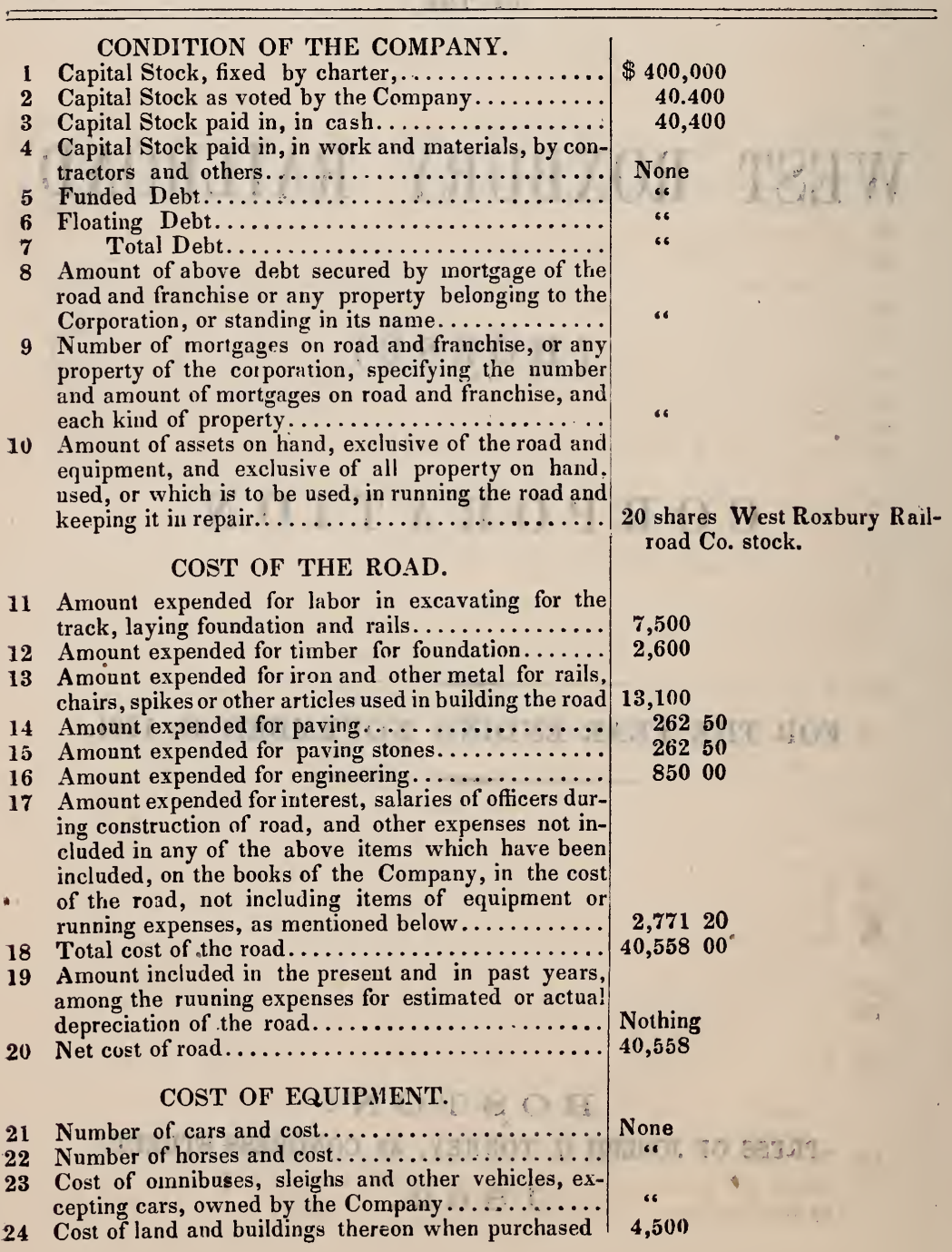


25 Cost of buildings used for offices, stables, \&c., erected by the Company, or standing on land not owned

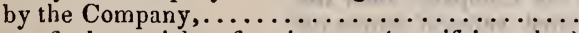

26 Cost of other articles of equipment, (specifying what)

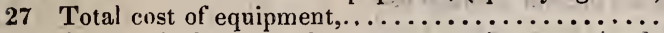

28 Amount included in the present and in past years in the running expenses for estimated or actual depre-

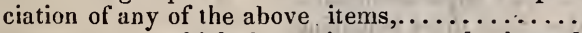

29 Net amount at which the equipment stands charged on the books of the Company,.............

\section{CHARACTERISTICS OF THE ROAD.}

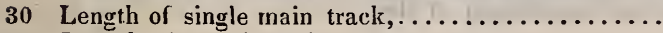

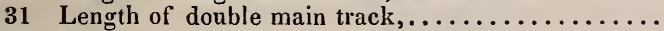

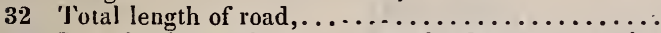

33 Length of branches owned by the Company, stating whether they have a single or double track,......

34 Aggregate length of switches, sidings, turnouts and other track, excepting main track and branches,...

35 Total length of rail,....................

36 Weight of rail used, per yard, (specifying whether

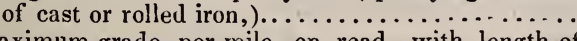

37 Maximum grade, per mile, on road, with length of

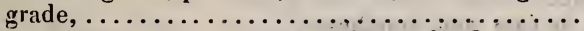

38 Shortest radius of curvature, with length of curve,..

39 Greatest length of single track on road between two

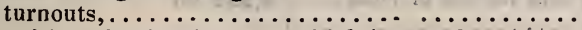

40 Total length of main track which is paved,........

DOINGS DURING THE YEAR.

41 Total number of miles run during the year, .......

42 Number of passengers carried in the cars, ........

43 Rate of speed adopted, including stops and detentions,

44 Rate of speed actually attained including stops and

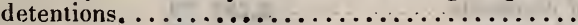

45 Number of persons employed, regularly, (specifying the occupations of esch, $\ldots \ldots \ldots \ldots \ldots \ldots \ldots \ldots$

46 Total number of trips run during the year.........

47 Average number of passengers each trip.........

EXPENDITURES FOR WORKING THE ROAD.

48 For repairs of road, including repairs of foundation, renewals of iron, and renewals of pavement.....

49 For general repairs, including repairs of cars, omnibusses and harnesses, and for shoeing horses, ....

50 For repairs of real estate, including repairs of buildings used as stables, offices, or for any other purposes, by the Company,..................

51 For wages, including the wages of every person regularly employed, excepting the president, directors,

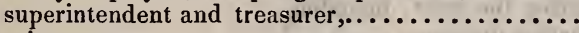

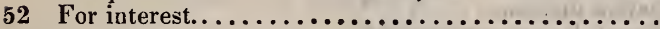

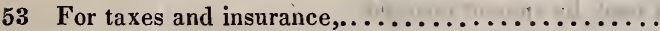

54 For tolls paid other companies for the right to pass

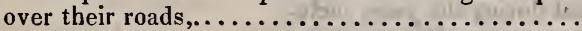

55 For rent paid other companies for use of their roads;

56 For provinder, - to include cost of hay, grain, straw, or other articles used for the food \& bedding of horses

57 For miscellaneous articles purchased during the year - such as harnesses, blankets, \&c., the use of which continues for one or more years, - and not

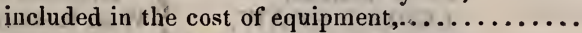

53. For loss on horses-that is to say, the difference between the present estimated value of horses owned by the Company substracted from the esimated val-

\section{$\$ 8,67880$ \\ None \\ 13,17880}

\section{Nothing}

13,17880

1 20-100 miles

67-100 "c

$254-100$ c6

None

567 feet

2 54-100 miles

cast $63 \mathrm{lbs}$. per yd. $187-100 \mathrm{~m}$. wro't 55 libs. per yd. 67-100 ".

$290 \mathrm{ft}$. per mile, $220 \mathrm{ft}$ long

43 73-100 ft., 70 9-10 ft. long

75-100 mile

about 1200 feet

The road is leased to, equipped and run by the Metropoli$\tan$ Railroad Co. 
ue of those on hand at the commencement of the year, added to the cost of those purchased during the year; or if this is the first report of the Company, then the difference between the estimated value of horses on hand, and their cost-giving the present average estimated value of each horse...................

59 For incidental expenses, - to include printing, president's, directors', treasurer's, and superintendent's salaries, and all expenses other than those belonging to the actual working of he road................

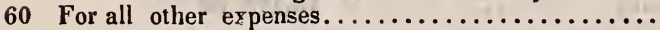

61 For amount charged on the Company's books during the year for estimated or actual depreciation of the following property :

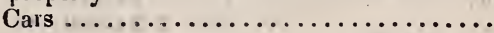

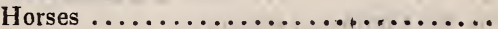

Omnibuses......................

Real Estate.......................

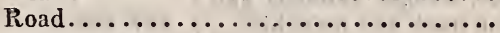

Other property.$\ldots \ldots \ldots \ldots \ldots \ldots \ldots$

Total...........................

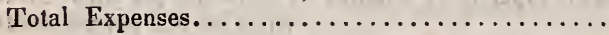

\section{EARNINGS.}

63 Received from passengers in cars and omnibuses,

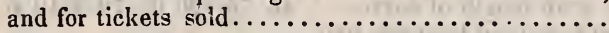

64 From other roads, as toll or rent for use of road....

65 From United States Mails...................

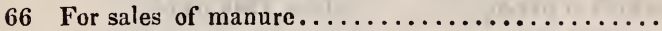

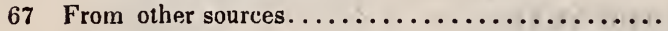

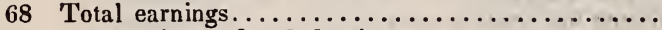

69 Net earnings, after deducting expenses.............

70 Surplus earnings of previous year, on hand........

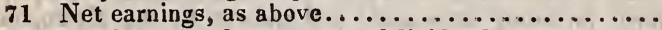

72 Total surplus for payment of dividends...........

73 Dividends declared during the year...............

74 Total percentage of dividends, for the year.........

Present surplus.

\section{MISCELLANEOUS.}

Increase during the year :

Of capital stock, as fixed by the charter...

Of capital stock as voted by the Company

Of capital stock paid in...............

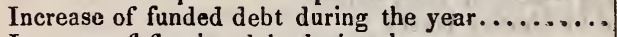

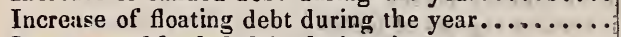

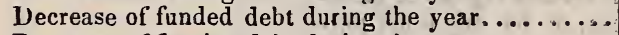

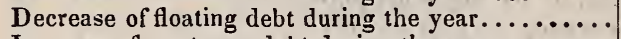

Increase of mortgage debt during the year..........

Decrease of mortgage debt duriug the year...........

83 Increase in cost of road during the year, including amount charged for depreciation thereon.........

81 Decrease in nominal cost of road, by amount charged for depreciation thereon

85 Increase in cost of equipment during the year, including amonnt charged for depreciation thereon......

86 Decrease in cost of equipment, by sale of any portion thereof, or by amount charged for depreciation.

List of accidents on the road during the year.......

8000

3,31200

3.24784

2495

3,24784

3,28279

3,23200

Eight per cent.

5079

\section{J. G. WELD, LEMUEL SHAW, \\ GEO. H. WILLIAMS, $\}$ road Company.}

SuFfork, SS. December 23d, 1861. Then personally appeared J. G. Weld, Lemuel Shaw, and Geo. H. Williams, and severally made oath to the truth of the foregoing statement by them subscribed, according to the best of their knowledge and belief,
Before
D. S. GREENOUGH, Justice of the Peace. 


\title{
TWENTY-SEVENTH ANNUAL REPORT
}

\author{
OF THE
}

\section{Western Railroad Corporation,}

FOR THE YEAR ENDING NOVEMBER 30, 1861.

Report of the Western Railroad under the Acts of 1849, Chap. 191; 1851, Chap. 102; 1854, Chap. 423; 1856, Chap. 165; 1857, Chapters 40, 168 and 240.

Capital Stock

Number of Shares of capital stock issued.........

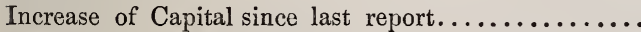

Capital paid in, per last report............ \$5,150,000 00

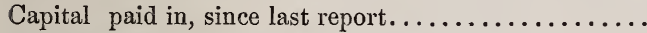

Total Amount of Capital Stock paid in..........

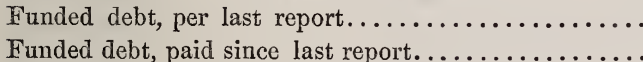

Funded debt, increase of, since last report..........

Total present amount of funded debt............

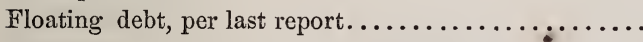

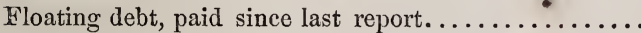

Floating debt, increase of, since last report.........

Total present amount of floating debt............

Total present amount of funded and floating debt......

Average rate of interest per annum paid during the year.

Maximum amount of debts during the year.........

51,500

$6,269,52000$

2,00000

76,00000
$\$ 6,150,00000$

$6,271,52000$

76,00000

$6,347,52000$

5 1-2 per cent.

188,00000

\section{Cost of Road and Equipment.}

For graduation and masonry, per last report......\$3,491,365 36

For graduation and masonry, paid during the past year. $\quad 35,53570$

Total amount expended for graduation and masonry..

For wooden bridges, per last report............

For wooden bridges, paid during the past year.......

Total amount expended for wooden bridges.........

Total amount expended for iron bridges (if any).....

For superstructure, including iron, per last report.....

For superstructure, including iron, paid during the

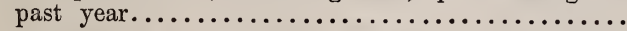

Total amount expended for superstructure, including iron
$3,526,90106$

231,99626

1,00000

232,99626

None.

$1,685,35830$

$68,363 \quad 15$ 
For stations, buildings and fixtures, per last report.... 450,69958

For stations, buildings and fixtures, paid during the past year.................................

Total amount expended for stations, buildings and

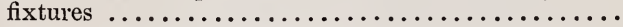

For land, land damages and fences, per last report....

For land, land damages and fences, paid during the

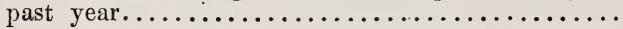

Total amount expended for land, land damages and fences .................................

For locomotives, per last report................

For locomotives, paid during the past year..........

Total amount expended for locomotives............

For passenger and baggage cars per last report........

For passenger and baggage cars, paid during the past

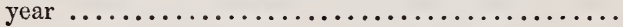

Total amount expended for passenger and baggage cars

For merchandise cars, per last report..............

For merchandise cars, paid during the past year.......

Total amount expended for merchandise cars.........

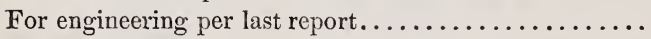

For engineering, paid during the past year..........

Total amount expended for engineering............

For agencies and other expenses per last report.......

For agencies and other expenses paid during the past

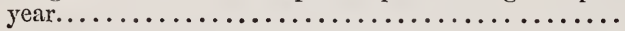

Total amount expended for agencies and other expenses

Total cost of Albany and West Stockbridge Railroad.

Total cost of Hudson \& Boston and West Stockbridge

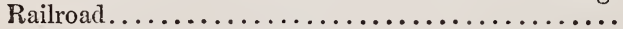

Total cost of road and equipment.............

Amount of assets of property held by the corporation in addition to the cost of the road.....\$607,017 17

Less dividends, accrued interests, \&c......299,426 32

307,59085

Value of Sinking Funds..........\$2,500,292 49

450,69958

298,20070

1,12031

299,32101

432,00000

432,00000

$73,544 \quad 55$

$73,544 \quad 55$

590,16842

590,16842

171,39063

171,39063

$1,019,15741$

$1,019,15741$

$2,388,35922$

196,88898

$\$ 11,135,158 \quad 57$

$\$ 2,807,88334$

\section{Characteristics of Road.}

Length of road, (Western Railroad, 117 miles 4248 feet ; Albany \& West Stockbridge, 38 miles 1180 feet).... $\} 156$ miles 148 feet.

Length of single main track...................

Length of double main track...................

Length of branches owned by the company, stating whether they have a single or double track. Hudson and Boston Railroad........................

Aggregate length of sidings, and other tracks, excepting main track and branches....................

Weight of rail per yard, in main road..............

Weight of rail per yard, in branch roads. (Specify the different weights per yard)..$\ldots \ldots \ldots \ldots \ldots \ldots \ldots$.

Maximum grade, with its length, in main road...... 83 feet-1 1-2 miles.

47 miles 4690 feet.

108 miles 738 feet.

17 miles 1742 feet.

10 miles 180 feet.

56 to $64 \mathrm{lbs}$ per yard. 
Maximum grade, with its length, in branch roads..... Total rise and fall in main road .................... Total rise and fall in branch roads................ Shortest radius of curvature, with length of curve, in main road...............................

Shortest radius of curvature, with length of curve in branch roads. .

Total degrees of curvature in main road............

Total degrees of curvature in branch roads...........

Total length of straight line in main road...........

Total length of straight line in branches............

Aggregate length of wooden truss bridges...........

Aggregate length of all other wooden bridges.........

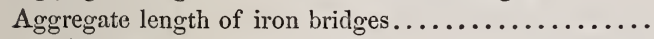

Whole length of road unfenced on both sides.........

Number of public ways crossed at grade.............

Number of railroads crossed at grade.............

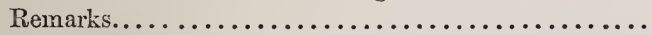

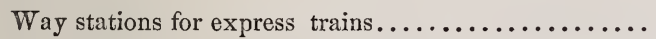

Way stations for accommodation trains.............

Flag stations.............................

Whole number of way stations..................

Whole number of flag stations...................

\section{Doings during the Year.}

Miles run by passenger trains..................

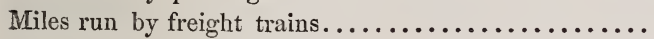

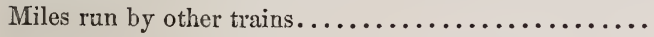

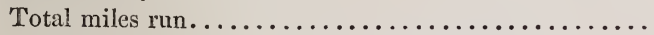

Number of passengers carried in the cars...........

Number of passengers, carried one mile.............

Number of tons of merchandise carried in the cars....

Number of tons of merchandise carried one mile......

Number of passengers carried one mile to and from

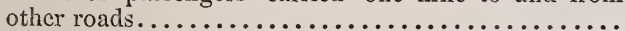

Number of tons carried one mile to and from other roads

Rate of speed adopted for express passenger trains, including stops...............................

Average rate of speed actually attained by express passenger trains, including stops and detentions........

Rate of speed adopted for accommodation trains......

Rate of speed actually attained by accommodation trains, including stops and detentions...................

Average rate of speed actually attained by special trains, including stops and detentions..................

Average rate of speed adopted for freight trains, inclu-

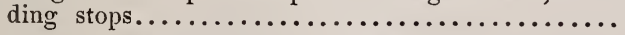

Estimated weight in tons of passenger cars, (not including passengers) hauled one mile................

Estimated weight in tons of merchandise cars, (not including freight) hauled one mile...
4893 feet.

559 feet.

882 feet -490 feet long.

$6,370^{\circ}$

62 miles 935 feet.

6,092 1-2 feet.

\section{9}

3

3

36

4

40

4.

382,845

804,136

47,036

$1,234,018$
563140
$23,009,035$
508,179
$47,924,408$

$15,411,171$

$35,607,511$

30 miles per hour.

32 miles per hour.

Springfield_\& Wor. 28 miles Alb. 22 "

15 miles per hour. 
Expenditures for Working the Road.

For repairs of road, maintenance of way, exclusive of wooden bridges and renewals of iron............ \$222,102 22

For renewals of iron.............\$104,608 51

For repairs of wooden bridges.................. 11,18759

For wages of switchmen, average per month......\$26

For wages of gate-keepers, average per month....\$20

For wages of signal men, average per month.....\$20

For wages of watchmen, average per month......\$30

Number of men employed, exclusive of those engaged

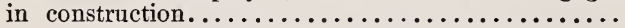

For removing ice and snow, (this item to include all labor, tools, repairs, and extra steam power used)...

For repairs of fences, gates, houses for signal men, gate keepers, switchmen, tool-houses................

Total for maintenance of way...............

\section{Motive Power and Cars.}

For repairs of locomotives....................

For new locomotives, to cover depreciation..........

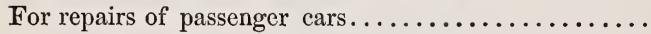

For new passenger cars, to cover depreciation.........

For repairs of merchandise cars.................

For new merchandise cars, to cover depreciation......

For repairs of gravel and other cars...............

Total for maintenance of motive power and cars. .

Number of Engines..................... 72

Number of passenger cars................. 49

Number of baggage cars................... 12

Number of merchandise cars................. 1050-8 wheel.

Number of gravel cars.................... 80

\section{MISCELLANEOUS.}

For fuel used by engines during the year, viz:

Cumberland Coal 1200 tons,.................. Wood, number of cords, 47,007 Cost of the same..

Coal, number of tons, (reckoning 2,240 lbs to the ton,) 2276 Cost of same........................

For Oil used by engines and cars.................

For waste and other material for cleaning...........

For salaries, wages and incidental expenses, chargea- ) ble to passenger department.................

For salaries, wages and incidental expenses, chargea-

$67,075 \quad 69$

15,00000

$26,851 \quad 58$

104,06286 ble to freight department...................

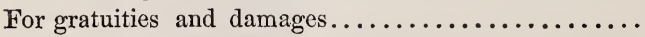

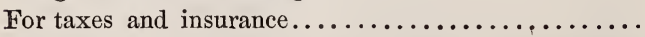

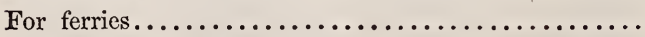

For repairs of station buildings, acqueducts, fixtures, furniture 
For amount paid other companies, in tolls for passengers and freight carried on their roads, specifying each company

For amount paid other companies, as rent for use of their roads, specifying each company.

For salaries of president, treasurer, superintendent, law expenses, office expenses of the above offices, and all other expenses not included in any of the foregoing

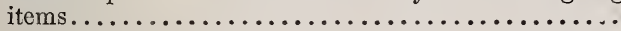

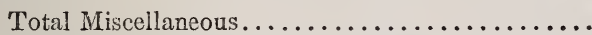

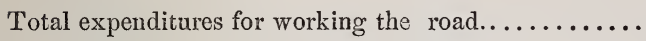

Total amount of interest paid during the year........

20,44790

628,96388

$1,081,571 \quad 17$

\section{Income During the Year.}

\section{For Passengers :-}

1. On main road, including branches owned by

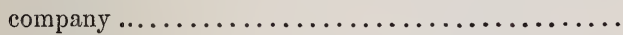

2. To and from other roads, specifying what......

For Freight:-

1. On main road and branches owned by company. $1,164,32023$

2. To and from other connecting roads..........

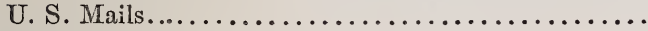

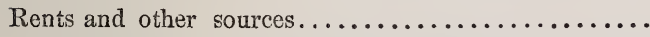

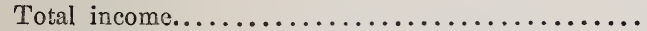

Net earnings, after deducting expenses...........

\section{Dividends.}

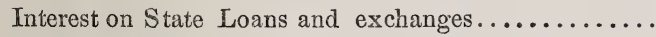

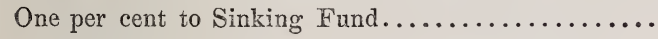

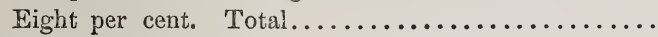

Loss on Pittsfield \& North Adams Railroad.........

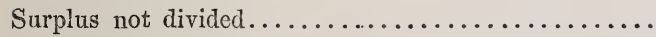

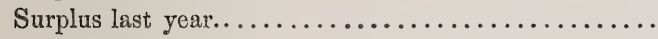

$37,475 \quad 54$

79,40711

$1,894,56796$

$\$ 812,996 \quad 79$

338,95243

50,00000

412,00000

$7,93981-808,89224$

4,10455

400,64433

Total Surplus

$\$ 404,74888$

Estimated Depreciation befond the Renewals, VIZ.

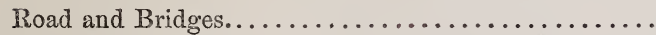

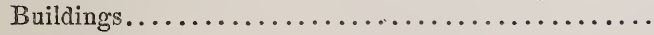

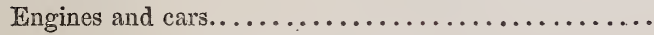

\section{Mortgage Debts.}

Amount of debts secured by mortgage of road and franchise, or any property of the corporation, per last

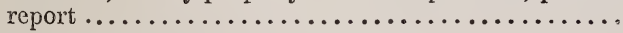

Mortgage debt, paid since last report

Mortgage debt, increase of, since last report.......... Present amount of Mortgage debts

Number of Mortgages on road and franchise, or any property of the corporation. 
LIST OF ACCIDENTS UPON THE WESTERN RAILROAD FOR THE YEAR ENDING NOV. 30, 1861.

December 24, 1860.--Joln Hogan a brakeman on Freight Train, was killed at Indian Orchard by falling from the cars and the train running over him.

April 2, 1861.- Henry Harper, walking upon the track at Worcester, was struck by the Engine and killed.

July 12, 1861.-Alfred White, walking upon the track at Dalton, was struck by the Engine and killed.

September 12, 1861.-A stranger, walking upon the track at Warren, was struck by the Engine and killed. Name unknown.

October 4, 1861.-Archer Michael and Edward Madden were walking upon the track at Pittsfield, and were struck by the Engine and badly injured.

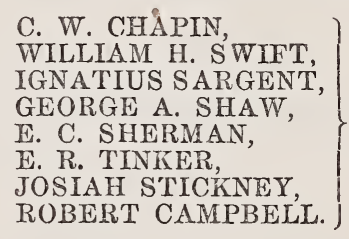

C. W. CHAPIN, WILLIAM H. SWIFT, GEORGE A. SHAW, E. C. SHERMAN, E. R. TINKER ROBERT CAMPBELL.
Direciors of the

Western Railroad

Corporation.

\section{COMMONWEALTH OF MASSACHUSETTS.}

SUFFOLK, SS.

December 24, 1861.

Then personally appeared C. W. Chapin, William H. Swift, Ignatius Sargent, George A. Shaw, E. C. Sherman, I. R. Tinker, Josiah Stickney and Robert Campbell, and severally made oath to the truth of the foregoing statement by them subscribed, 


\section{REPORT OF THE DIRECTORS}

\section{OF}

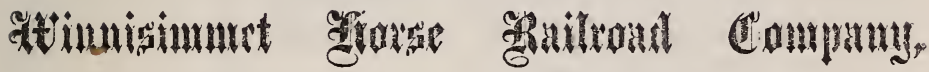

For the Year ending November 30, 1861.

\section{Condition of the Company.}

CapitaI Stock, fixed by charter,

Capital Stock, as voted by the Company,

$\$ 75,000 \quad 00$

$75,000 \mathrm{CO}$

Capital Stock, paid in, in cash,

$22,200 \quad 00$

Capital Stock, paid in, in work and materials,

by contractors and others,

Funded debt,

Floating debt,

Total debt,

Amount above debt secured by mortgage of the road and franchise; or any property belonging to the Corporation, or standing in its name,

Number of mortgages on road and franchise, or any property of the. Corporation, specifying the number and amount of mortgages on road and franchise, and each kind of propcrty,

Amount of assets on hand, exclusive of the road and equipment, and exclusive of all property on hand, used, or which is to beused, in running the road and keeping it in repair, 
Cost of the Road.

Amount expended for labor in excavating for ? the track, Jaying foundation and rails, Amount expended for timber for fondation, Amount expended for iron and other metal for rails, chairs, spikes, or other articles, used in building the road,

Amount expended for paving,

Amount expended for paving stones, Amount expended for engineering,

Amount expended for interest, salaries of officers during construction of road, and other expenses not included in any of the above items, which have been included, on the books of the Company, in the cost of the road, not including items of equipment or running expenses, as mentioned below, Total cost of road,

Amount included in the prescnt and in past years, among the running expenses for estimated or actual depreciation of the road, Net cost of road,
Road built by

Contract.

$\$ 62,15174$

\section{Cost of Equipment.}

No. of cars and costit,

No. of horses and cost,

Cost of omnibuses, sleighs, and other vehicles, excepting cars, orned by the Company, Cost of land, and buildings thereon when purchased,

Cost of buildings used for offices, stables, \&c., erected by the Company, or standing on land not owned by the Company,

Cost of other articles of equipments, (specifying what)

None.

Road Leased. 
Total cost of equipment,

Amount included in the present and in past years in the running expenses for estimated or actual depreciation of any of the above items,

Net amount at which the equipment stands charged on the books of the Company,

Characterisics of the Road.

Length of single main track,

About $2 \frac{1}{4}$ miles.

Length of double main track,

Total length of road,

About $2 \frac{1}{4}$ miles.

Length of branches orned by the Company, stating whether they have a single or double track,

Aggregate length of switches, sidings, turnouts, and other track, excepting main track and branches,

About 1800 feet.

Total length of rail,

Weight of rail used, per yard, (specifying? whether of cast or rolled iron)

Rolled Iron. 45 pounds per yard.

Maximum grade per mile on road, with length of grade,

Shortest radius of curvature, with length of curve,

Greatest length of single track on road between two turnouts,

Total length of main track which is paved,

Doings During the Kear to Oct. 1, 1861.

Total number of miles run during the year, including Ferry of 3 miles to a trip, 
Nurnber of passengers carried in the cars,

Rate of speed adoptcl, includng stops and detentions,

6 miles per hour.

Rate of speed actually attained, including stops and detentions,

Nunber of persons employed regularly, (speci-

fying the occupations of cach, ) -

17 conductors and drivers,

6 stable hands,

1 superintendent,

2 on ferry,

22 men.

Total number of trips run during the year,

Average number of passengers each trip,

6 miles per hour.

16,256

$14 \frac{1}{2}$

\section{Expenditures for Worling the Road.}

For repairs of road, including repairs of foundation, renewals of iron, and renewals of parements,

For general repairs, including repairs of cars, omnibuses, and harnesses, and for shceing horses,

$\$ 73160$

For repairs of real estate, including repairs of building used as stables, offices, or for any other purposes by the Company,

For wages, including the wages of every person regularly employed, excepting the President, Directors, Supcrintendent, and Treasurer,

For interest,

For taxes and insurance,

For tolls paid other companies, for the right to pass over their roads,

For rent paid other companies for use of their roads, 
For provender,-to include cost of hay, grain, straw, and other articles used for food and bedding of horses,

For miscellaneous articles purchasel during the year-such as harnesses, blankets, \&c., the use of which continues for one or more years - and not included in the cost of equipment,

For loss on horses - that is to say, the difference between the present estimated ralue of the horses owned by the Company, subtracted from the estimated value of those on hand at the commencement of the year, added to the cost of those purchased during the year; or if this is the first report of the Company, then the difference between the estimated value of the horses on hand and their cost-giving the present estimated value of each horse,

For incidental expenses,- to include printing, President's, Directors', Treasurer's, and Superintendent's salaries, and all expenses other than those belonging to the actual working of the road,

For all other expenses,

For amount charged on the Company's books, during the yeir, for estimated or actual depreciation of the following property :-

Cars,

Horses,

Omnibuses,

Real Fistate.

Road,

Other property,

Total,

Total expenses, 


\section{Earnings.}

Received from passengers in cars and omnibuses; and for tickets sold,

From other roads, as toil or rent for use of road, $\$ 9,16492$

From United States mails,

For sales of manure,

From other sources,

8300

Total earnings,

Net earnings, after deducting expenses,

Surplus earnings of previous year on hand,

Net earnings, as above,

Total surplus for payment of dividends,

Dividends declared during the year,

Total percentage of dividends for the year,

Present surplus,

\section{Miscellaneous.}

Increase during the year-

Of capital stock, as fixed by the charter,

Of capital stock, as voted by the Company,

Of cupital stock, paid in,

Increase of funded debt, during the year, Increase of floating debt, during the year, Decrease of funded debt, during the year, Decrease of flo:ting debt, during the year, -

Increase of mortgage debt, during the year, -

Decrease of mortgage debt, during the year,

Increase in cost of road, during the year, including amount charged for depreciation thereon,

Decrease in nominal cost of road, by amount charged for depreciation thereon,

Increase in cost of equipment, during the year, including amount charged for depreciation thereon, 
Decrease in cost of equipment, by the sale of any portion thereof, or by amount charged for depreciation,

List of Accidents on the Road during the Year. None.

Road leased from Oct. 1, 1861, to Lynn \& Boston R. R.

ISAAC STEBBINS, CHARLES A. DAVIS, W. R. PEARMAIN, BENJAMIN SHUR'TLEFF, PASCHAL P. P. WARE, CALEB YRATT, A. M. KIDDER,

Directors of Winnisimmet Railroad Company.

Suffolk, ss. December 18, 1861.

Then personally appeared Isaac Stebbins, Charles A. Davis, W. R. Pearmain, Benjamin Shurtleff, Paschal P. P. Ware, Caleb Pratt, and A. M. Kidder, and severally made oath to the truth of the foregoing statement by them subscribed.

Before me,

J. B. LOOMIS, Notary Public. 



\section{R $\mathrm{E} P \mathrm{R} \mathrm{T}$.}

OF THE DIRECTORS OF THE

\section{Worcester \& Nashua Railroad Corporation,}

For the Year Ending November 30, 1861.

\begin{tabular}{l}
\hline Capital Stock, \\
Number of shares of capital stock issued, - \\
Increase of capital since last Report, \\
Capital paid in, per last Report, \\
Capital paid in, since last Report, \\
Total amount of capital stock paid in, \\
Funded debt, per last Report, \\
Funded debt, paid since last Report, \\
Funded debt, increase of, since last Report, \\
Total present amount of funded debt, \\
Floating debt, per last Report, \\
Floating debt, paid since last Report, \\
Floating debt, increase of, since last Report, \\
Total present amount of floating debt, \\
Total present amount of funded and floating debt,
\end{tabular}

Average rate of interest per annum, paid during the year,

Maximum amount of debts during the year,

Cost of Road and Equipment.

For graduation and masonry, per last Report,

For graduation and masonry, paid during the past year, Total amount expended for graduation and masonry,

For wooden bridges, per last Report,

For wooden bridges, paid during the past year, .

Total amount expended for wooden bridges,

Total amount expended for iron bridges, (if any),

For superstructure, including iron, per last Report,

For superstructure, including iron, paid during the past year,

Total amount expended for superstructure, including iron, -

For stations, buildings and fixtures, per last Report,
For stations, buildings and fixtures, paid during the past year,

Total amount expended for stations, buildings and fixtures,

For land, land-damages, and fences, per last Report,

For land, land-damages, and fences, paid during the past year,

Total amount expended for land, land-damages and fences,

For locomotives, per last Report, - .

For locomotives, paid during the past year,

Total amount expended for locomotives,

For passenger and baggage cars, per last Report,

For passenger and baggage cars, paid during the past year,

Total amount expended for passenger and baggage cars,

For merchandise cars, per last Report,

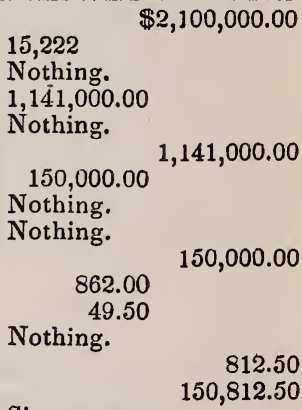

Nothing.

$1,141,000.00$

Nothing.

$150,000.00$

$1,141,000.00$

Nothing.

Nothing.

862.00

49.50

Nothing.

$\$ 2,100,000.00$

$150,000.00$

812.50

$150,812.50$

Six per cent.

$150,862.00$

$\$ 464,709.66$

Nothing.

Nothing.

$12,363.53$

$464,709.66$

$12,363.53$

Have none.

$414,373.25$

Nothing.

$79,467.95$

$400,000.00$

Nothing.

$185,540.74$

$70,000.00$

Nothing.

$62,853.12$

$179,232.17$

Nothing.

$17,612,71$

$\cdot 62,853.12$

Nothing.

$60,495.81$ 
For merchandise cars, paid during the past year,

Total amount expended for merchandise cars,

For engineering, per last Report, - . .

For engineering, paid during the past year,

Total amount expended for engineering, .

For agencies and other expenses, per last Report,

For agencies and other expenses, paid during the past

Total amount expended for agencies and other ex-

Total cost of road and equipment, - -

Amount of assets or property held by the corporation in addition to the cost of the road,

\section{Characteristics of Road.}

Length of road,

Length of single main track,

Length of double main track,

Length of branches owned by the Company, stating whether they have a single or double track,

Aggregate length of sidings, and other tracks, excepting main tracks and branches,

Weight of rail per yard, in main road, -

Weight of rail per yard, in branch roads, (specify the different weights per yard),

Maximum grade, with its length, in main road, -

Maximum grade, with its length, in branch roads,

Total rise and fall in main road, -

Total rise and fall in branch roads, -

Shortest radius of curvature, with length of curve, in main road, - - ${ }^{-}$- $-\dot{-}$ -

Shortest radius of curvature, with length of curve, in branch roads,

Total degrees of curvature in main road,

Total degrees of curvature in branch roads,

Total length of straight line, in main road,

Total length of straight line in branches, -

Aggregate length of wooden truss bridges,

Aggregate length of all other wooden bridges,

Aggregate length of iron bridges,

Whole length of road unfenced on both sides,

Number of public ways crossed at grade,

Number of railroads crossed at grade,

Remarks,

Way stations for express trains, -

Way stations for accommodation trains, :

Flag stations,

Whole number of way stations,

Whole number of flag stations,

DoINGS DURING THE YeAR.

Miles run by passenger trains,

Miles run by freight trains,

Miles run by other trains, .

Total miles run,

Number of passengers carried in the cars,

Number of passengers carried one mile,

Number of tons of merchandise carried in the cars,

Number of tons of merchandise carried one mile,

Number of passengers carried one mile, to and from other roads.

Number of tons carried one mile, to and from other roads,

Rate of speed adopted for express passenger trains, including stops,
Nothing.

$31,063.27$

Nothing.

$50,000.00$

$23,739.15$

417.59

Nothing.

$1,328,897.631,278,897.63$

$72,080.53$

$4569-100$ miles.

45 69-100 miles.

76.100 mile.

None.

8 1-2 miles.

56 to 58 lbs.

( 48 48-100 feet per mile for 344.100 miles, and $5280.100 \mathrm{ft}$. per mile for 800 feet.

$115130-100$ feet.

1146 feet for $\$ 6.100$ mile.

$2110^{\circ} 47^{\prime}$

31 miles.

559 feet.

335 feet.

None.

54

3

None.

13

1

13

1

58,872

69,466

3,333

139,538

$2,891,754$

86,294

$2,087,493$
161,671 
Average rate of speed actually attained by express passenger trains, including stops and detentions,

Rate of speed adopted for accommodation trains,

Rate of speed actually attained by accommodation trains, including stops and detentions,

Average rate of speed actually attained by special trains, including stops and detentions,

Average rate of speed adopted for freight trains, including stops,

Estimated weight in tons of passenger cars, (not includ. ing passengers), hauled one mile,

Estimated weight in tons of merchandise cars, (not including freight), hauled one mile,

\section{Expenditures for Woriting the Road.}

For repairs of road, maintenance of way, exclusive of wooden bridges, and renewals of iron,

For repairs of wooden bridges,

For wages of switchmen, average per month, $\$ 31$,

For wages of gate-keepers, average per month, $\$$

For wages of signal-men, average per month, $\$ 21$,

For wages of watchmen, average per month, $\$ 35$,

Number of men employed, exclusive of those engaged in

For removing ice and snow, (this item to include all labor, tools, repairs and extra steam power used),

For repairs of fences, gates, houses for signal men, gate. keepers, switchmen, tool-houses,

Total for maintenance of way,

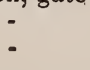

10 miles per hour.

23 miles per hour.

Motive Power and Cars.

For repairs of locomotives,

For new locomotives, to cover depreciation,

For repairs of passenger cars, -

For repairs of merchandise cars, -

For new merchandise cars, to cover depreciation,

For repairs of gravel and other cars,

Total for maintenance of motive power and cars,

Number of engines,

Number of passenger cars,

Number of baggage cars,

Number of merchandise cars,

Nurnber of gravel cars,

\begin{tabular}{|c|}
\hline$\theta$ \\
\hline - \\
\hline - \\
\hline
\end{tabular}

\section{Miscellaneous.}

For fuel used by engines during the year, viz. : .

Wood, number of cords, Cost of the same,

Coal, number of tons, (reckoning 2,240 lbs. to the ton, ) Cost of same, :

For oil used for cars and engines, - :

For salaries, wages, and incidental expenses, chargeable to passenger department,

For salaries, wages, and incidental expenses, chargeable to freight department,

For gratuities and damages,

For taxes and insurance, : $\quad: \quad:$

For ferries, - - : : :

For repairs of station buildings, aqueducts, fixtures, furniture,

For renewals of iron, including laying down, :

Nor new iron laid down, deducting the value of old iron taken up,

For amount paid other companies, in tolls for passengers and freight carried on their roads, specifying each company, 
For amount paid other companies, as rent for use of their roads, specifying each company,

For salaries of president, treasurer, superintendent, law expenses, office expenses of the above offices, and all other expenses, not included in any of the foregoing items,

Total Miscellaneous, -

Total expenditures for working the road, -

Total amount of interest paid during the year, .

\section{InCOME DURING The YeAR.}

For Passengers :-

1. On main road, including branches owned by com. pany,

2. To and from other roads, specifying what,

For Freight:-

1. On main road and branches owned by company,

2. To and from other connecting roads,

U. S. Mails,
Rents [and Express],

Total income,

Net earnings, after deducting expenses, : :

\section{Dividends.}

$\$ 4$ per share. Total, Surplus not divided,

Surplus last year, Total surplus,

$\begin{array}{lllll}- & - & & - & - \\ - & - & & - & - \\ - & - & & - & \text { - } \\ - & - & & - & \text { - }\end{array}$

Estimated Depreciation Beyond the Renewals, viz :

Of road and bridges,

Buildings,

Engines and cars, .

\section{Mortgage Debts.}

Amount of debts secured by mortgage of road and franchise, or any property of the corporation, per last Report,

Mortgage debt paid since last Report,

Increase of mortgage debt since last Report.

Present amount of mortgage debts,

Number of mortgages on road and franchise, or any property of the Corporation,
$9,845.39$

$76,662.12$

$112,481.35$

$8,192.11$

$\$ 84,674.92$

$103,117.64$

$4,625.00$

$3,252.22$

$195,669.78$

$\$ 60,8 \mathrm{~S} 8.00$

$14,103.32$

$45,057.34$

$\$ 150,000.00$

Nothing.

"6

$150,000.00$

One.

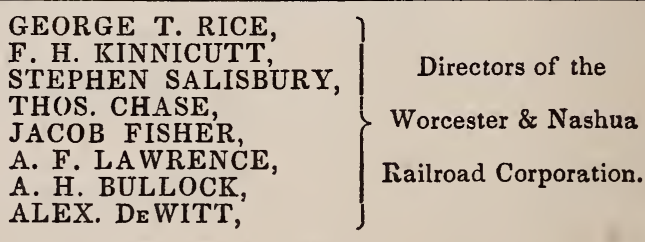

Worcester, ss., December 24, 1861.

Then personally appeared George T. Rice, F. H. Kinnicutt, Stephen Salisbury, Thos. Chase, Jacob Fisher, A. F. Lawrence, A. H. Bullock, and Alex. DeWitt, and severally made oath that the foregoing statement by them subscribed is true, according to their best knowledge and belief.

Before

T. W. HAMMOND, Justice of the Peace.

1, the subscriber, Commissioner of the Worcester \& Nashua Rail Road Company, appointed by the Governor of Massachusetts, having examined the foregoing Report, find it correct, and approve the same.

Worcester, December 26, 1861. 



